INSTITUTO DE PESQUISAS ENERGÉTICAS E NUCLEARES

Autarquia associada à Universidade de São Paulo

DESENVOLVIMENTO DE DERIVADOS DA BOMBESINA RADIOMARCADOS COM LUTÉCIO-177: RELAÇÃO ESTRUTURA E POTENCIAL DIAGNÓSTICOTERAPÊUTICO PARA TUMOR DE PRÓSTATA

PRISCILLA BRUNELLI PUJATTI

Dissertação apresentada como parte dos requisitos para obtenção do Grau de Mestre em Ciências na Área de Tecnologia Nuclear Aplicações

Orientadora:

Dra. Elaine Bortoleti de Araújo 
À papai e mamãe por fazerem de meus sonhos os seus e tornarem mais esse possível, ao Marco pela amizade incondicional e ao João por jamais me permitir desistir.

"As coisas mais importantes da vida não são as coisas" (Autor desconhecido) 


\section{AGRADECIMENTOS}

À Deus. "A ciência humana de maneira nenhuma nega a existência de Deus. Quando considero quantas e quão maravilhosas coisas o homem compreende, pesquisa e consegue realizar, então reconheço claramente que o espírito humano é obra de Deus, e a mais notável" (Galileu Galilei).

À minha orientadora. "Nada lhe posso dar que já não exista em você mesmo. Não posso abrir-lhe outro mundo de imagens, além daquele que há em sua própria alma. Nada lhe posso dar a não ser a oportunidade, o impulso, a chave. Eu o ajudarei a tornar visível o seu próprio mundo, e isso é tudo" (Hermann Hesse).

Ao Instituto de Pesquisas Energéticas e Nucleares (IPEN), em especial ao Centro de Radiofarmácia, onde a maior parte dos estudos deste trabalho foi realizada.

Ao Msc. Jair Mengatti, por contribuir sempre prontamente com este trabalho, facilitando o provimento dos recursos necessários para sua realização e divulgação.

À Dra. Maria Tereza Colturato e à Dra. Tatiana Lavinas, que por meio de longas conversas e dos seus exemplos me ensinaram que "Nada deve ser receado, tem apenas de ser compreendido" (Marie Curie).

À Dra. Sibila Grallert pela contribuição com a modelagem molecular dos derivados da bombesina estudados neste trabalho.

À Dra. Emiko Muramoto. "Feliz aquele que transfere o que sabe e aprende o que ensina" (Cora Coralina).

Ao Dr. Carlos Soares e à Miriam Suzuki pela constante e fundamental colaboração com o trabalho.

Aos amigos:

da divisão de Produção de Radiofármacos do Centro de Radiofarmácia, em especial à Msc. Marysel e Rosana;

da divisão de Controle de Qualidade do Centro de Radiofarmácia, em especial à Msc. Neusa, Dra. Margareth, Idelí e Nathanael;

da divisão de Garantia da Qualidade do Centro de Radiofarmácia, em especial ao Fábio e Renato; 
da divisão de Pesquisa e Desenvolvimento do Centro de Radiofarmácia, em especial à Dra. Áurea, pela contribuição nos estudos em HPLC;

bolsistas do Centro de Radiofarmácia, em especial à Josefina, Laura, Renata, Adriana, Clarice, Kátia, Ivaní, Raquel, Akin e Érika.

"Se você quer ser feliz por uma hora, tire uma soneca; por um dia, vá pescar; por um mês, case-se; por um ano, herde uma fortuna; pela vida inteira, ajude os outros" (Ditado chinês).

Às amigas Vívian, Camila, Marcella e Luciana. “O valor das coisas não está no tempo que elas duram, mas na intensidade com que acontecem. Por isso existem momentos inesquecíveis, coisas inexplicáveis e pessoas incomparáveis" (Fernando Sabino).

À Rosemeire, pela amizade e contribuição com a análise histológica dos tumores.

Ao Hemocentro da UNICAMP, pelo fornecimento das células PC-3 utilizadas neste trabalho.

Aos funcionários do Biotério do IPEN, em especial à Neide pelo cuidado com os animais.

Aos funcionários da divisão de pós-graduação do IPEN.

Aos demais amigos e familiares de todas as partes.

Ao CNPq pela bolsa concedida. 
“Acredito que o verdadeiro ideal de vida é fazer o bem, ajudar as pessoas que nos são próximas. É amar. Ser conhecido profissionalmente pode até estimular o ego, mas não se compara ao fato de se ter a consciência de que se pratica o bem." 


\title{
DESENVOLVIMENTO DE DERIVADOS DA BOMBESINA RADIOMARCADOS COM LUTÉCIO-177: RELAÇÃO ESTRUTURA E POTENCIAL DIAGNÓSTICO- TERAPÊUTICO PARA TUMOR DE PRÓSTATA
}

\author{
Priscilla Brunelli Pujatti
}

\begin{abstract}
RESUMO
Os receptores para a bombesina $(\mathrm{BBN})$, especialmente o receptor para o peptídeo liberador de gastrina (GRPr), são massivamente expressos em vários tipos de câncer, dentre eles o câncer de próstata, e podem ser uma alternativa para seu diagnóstico e tratamento por terapia radioisotópica. Modificações moleculares na estrutura da BBN vêm sendo promovidas e os derivados produzidos têm apresentado bons resultados em estudos préclínicos. No entanto, todos os derivados estudados apresentaram alta captação abdominal e esta é a principal limitação do uso clínico da BBN, devido aos efeitos adversos aos pacientes. O objetivo deste trabalho foi radiomarcar uma nova série de derivados da bombesina com lutécio-177 e avaliar a relação entre sua estrutura e o potencial diagnóstico-terapêutico do câncer de próstata. Os peptídeos estudados apresentam estrutura genérica DOTA-Phe-(Gly) $)_{n}-B B N(6-14)$, em que DOTA é o grupamento quelante, n é o número de aminoácidos glicina do espaçador Phe-(Gly) e $\mathrm{BBN}(6-14)$ é a sequência original de aminoácidos da BBN do aminoácido 6 ao aminoácido 14. Estudos preliminares foram realizados a fim de avaliar a condição que conferia maior pureza radioquímica aos derivados radiomarcados, determinada por cromatografia em camada delgada (ITLC-SG) e cromatografia líquida de alta eficiência (CLAE). A estabilidade dos derivados radiomarcados foi avaliada após incubação à $2-8^{\circ} \mathrm{C}$ ou em soro humano à $37^{\circ} \mathrm{C}$ e o coeficiente de partição foi determinado em n-octanol:água. Estudos in vivo foram realizados em camundongos Balb-c sadios e Nude com tumor de células PC-3, a fim de
\end{abstract}


caracterizar biologicamente os derivados da bombesina. Estudos in vitro envolveram a avaliação do efeito dos derivados não radiomarcados sobre a proliferação das células PC-3. A análise em ITLC-SG e CLAE revelou que todos os derivados da bombesina foram radiomarcados com alta pureza radioquímica. Os derivados radiomarcados apresentaram alta estabilidade à $2-8^{\circ} \mathrm{C}$. A análise em soro humano indicou metabolismo tempodependente dos derivados pelas enzimas do soro e aumento da estabilidade com o acréscimo de aminoácidos glicina no espaçador após 4 horas de incubação, mas não após 24 horas. Os estudos em CLAE e de coeficiente de partição indicaram que os derivados da bombesina apresentam baixa lipossolubilidade, a qual decresce com o aumento do espaçador. Os derivados apresentaram rápido clareamento sanguíneo, rápida excreção, realizada primariamente por via renal, baixa retenção no organismo e baixo acúmulo abdominal nos estudos in vivo em camundongos Balb-c. Os estudos em camundongos Nude com tumor PC-3 mostraram a capacidade dos derivados de se ligar às células tumorais. Os dois peptídeos com maior espaçador apresentaram maior captação tumoral 1 hora após a administração endovenosa, mas o derivado com menor espaçador apresentou maior captação tumoral quatro e 24 horas após a administração. A ligação às células PC-3 in vivo mostrou ser específica e suficiente para a detecção do tumor por imagens cintilográficas, principalmente 30 minutos após a administração. Nos estudos in vitro, os derivados da bombesina estudados não apresentaram efeito proliferativo ou citotóxico sobre as células PC-3, o que os caracteriza como agonistas fracos ou antagonistas dos receptores para GRP. Os resultados deste trabalho mostraram, portanto, que todos os derivados estudados são promissores para aplicação in vivo. A maior captação tumoral dos derivados com maior espaçador na primeira hora após a administração indica que essas moléculas são os mais adequados para o diagnóstico por imagem de tumor de próstata. Já para aplicação em terapia radioisotópica, o derivado com menor espaçador é o mais adequado, devido à maior retenção tumoral. 


\title{
DEVELOPMENT OF LUTETIUM-LABELED BOMBESIN DERIVATIVES: RELATIONSHIP BETWEEN STRUCTURE AND DIAGNOSTIC-THERAPEUTIC ACTIVITY FOR PROSTATE TUMOR
}

\author{
Priscilla Brunelli Pujatti
}

\begin{abstract}
Bombesin (BBN) receptors - in particular, the gastrin-releasing peptide (GRP) receptor peptide - have been shown to be massively overexpressed in several human tumors types, including prostate cancer, and could be an alternative as target for its treatment by radionuclide therapy (RNT). A large number of BBN analogs had already been synthesized for this purpose and have shown to reduce tumor growth in mice. Nevertheless, most of the studied analogs exhibit high abdominal accumulation, especially in pancreas. This abdominal accumulation may represent a problem in clinical use of radiolabeled bombesin analogs probably due to serious side effects to patients. The goal of the present work was to radiolabel a novel series of bombesin derivatives with lutetium-177 and to evaluate the relationship between their structure and diagnostic-therapeutic activity for prostate tumor. The generic structure of studied peptides is DOTA-Phe-(Gly) $)_{n}-\mathrm{BBN}(6-14)$, where DOTA is the chelator, $\mathrm{n}$ is the number of glycine amino acids of Phe-(Gly $)_{\mathrm{n}}$ spacer and BBN(6-14) is the bombesin sequence from the amino acid 6 to the amino acid 14. Preliminary studies were done to establish the ideal labeling conditions for obtaining the highest yield of labeled bombesin derivatives, determined by instant thin layer chromatography (ITLC-SG) and high performance liquid chromatography (HPLC). The stability of the preparations was evaluated either after storing at $2-8^{\circ} \mathrm{C}$ or incubation in human serum at $37^{\circ} \mathrm{C}$ and the partition coefficient was determined in n:octanol:water. In vivo studies were performed in both healthy Balb-c and Nude mice bearing PC-3 xenografts, in order to characterize the
\end{abstract}


biological properties of labeled peptides. In vitro studies involved the evaluation of cold bombesin derivatives effect in PC-3 cells proliferation. Bombesin derivatives were successfully labeled with high yield at optimized conditions and exhibited high stability at $4^{\circ} \mathrm{C}$. The analysis of the stability in human serum suggested a time-course metabolic degradation of labeled peptides by serum enzymes. The addition of four glycine amino acids in the spacer of bombesin derivatives resulted in slower degradation by human serum enzymes after 4 hours of incubation. HPLC and partition coefficient studies showed that bombesin derivatives present low lipophilicity and the increase of glycine amino acids number in peptides spacers slightly reduced their lipophilicity. The radiolabeled bombesin derivatives presented fast blood clearance, rapid excretion, performed mainly by renal pathway, and low abdominal accumulation in in vivo studies in Balb-c mice. Investigations in Nude mice bearing PC-3 tumor showed that the radiopeptides can target tumor cells. Higher tumor uptake was observed with the derivatives of larger spacers at 1 hour post injection, but higher tumor retention after 4 and 24 hours was observed with the derivative of smaller spacer. In addition, tumor uptake showed to be specific and allowed tumor detection by scintigraphy imaging, especially 30 minutes post injection. In addition, the studied bombesin derivatives did not present proliferative or cytotoxic effect to PC-3 cells in vitro and can be characterized as weak agonists or antagonists of bombesin receptors. The results of this work showed that phenyl-glycine extended bombesin derivatives are promising for in vivo applications. The higher tumor uptake of derivatives with larger spacer suggests that these molecules are more applicable in diagnostic procedures. The derivative with smaller spacer is more useful to be applied in radionuclide therapy, because of its higher tumor retention. 


\section{SUMÁRIO}

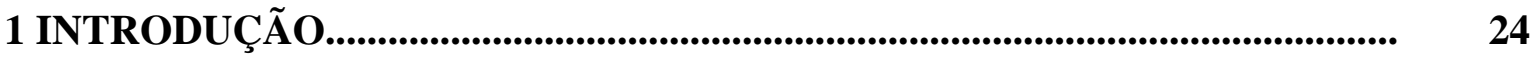

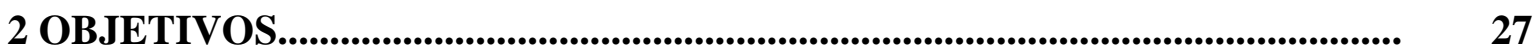

2.1 Objetivo geral.................................................................................................. 27

2.2 Objetivos específicos......................................................................................... 27

3 REVISÃO BIBLIOGRÁFICA......................................................................... 28

3.1 Neoplasia....................................................................................................... 28

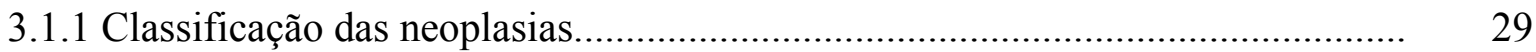

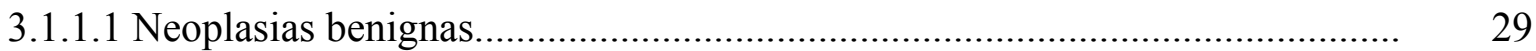

3.1.1.2 Neoplasias malignas ou câncer................................................................... $\quad 30$

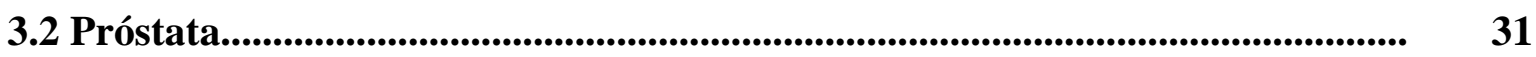

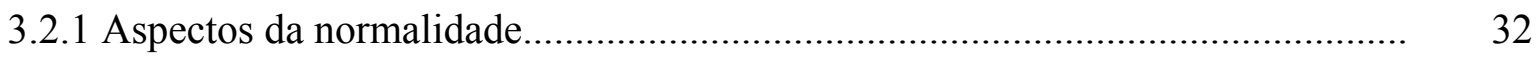

3.2.2 $\mathrm{O}$ câncer de próstata......................................................................................... 33

3.3 Medicina nuclear e radiofarmácia.................................................................................. 35

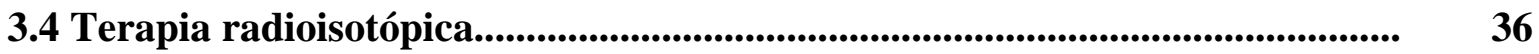

3.4.1 Considerações para o desenvolvimento de moléculas para terapia

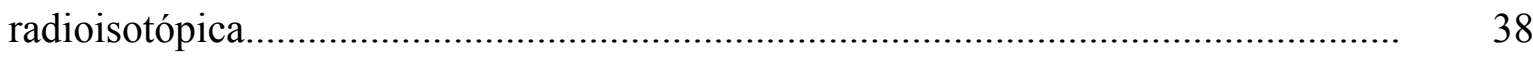

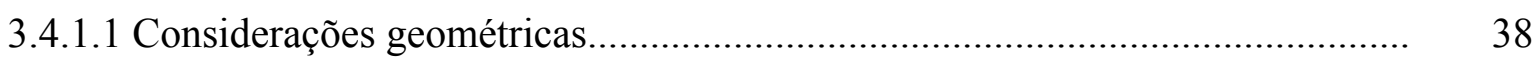

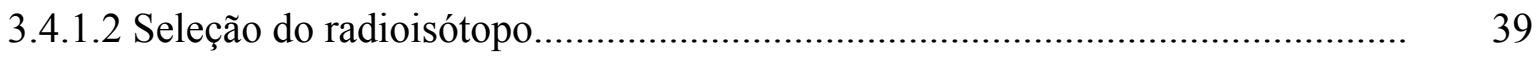

3.4.1.3 Seleção da molécula carreadora................................................................... 42

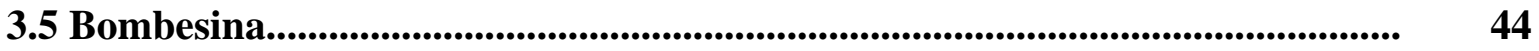

4 MATERIAIS E MÉTODOS................................................................................ 54

4.1 Planejamento experimental............................................................................... 54

4.2 Materiais...................................................................................................... 56

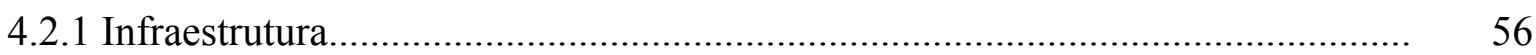

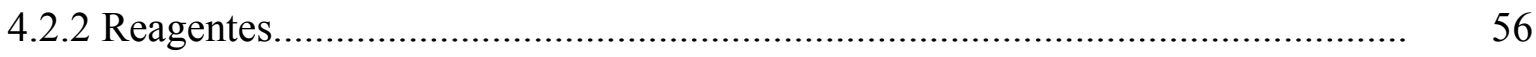

4.2.3 Materiais, equipamentos e sistemas............................................................. 57

4.2.4 Tampões e soluções.................................................................................... 58 
4.2.5 Peptídeos derivados da bombesina.

4.2.6 Animais.

4.2.7 Células PC-3 de adenocarcinoma de próstata humano.

4.3 Métodos.

4.3.1 Radiomarcação dos derivados da bombesina com lutécio-177.

4.3.2 Análise da pureza radioquímica dos derivados radiomarcados

4.3.2.1 Cromatografia ascendente em camada delgada em sílica gel 60 (ITLC$\mathrm{SG})$

4.3.2.2 Cromatografia líquida de alta eficiência (CLAE).

4.3.3 Análise da estabilidade dos derivados radiomarcados.

4.3.3.1 Análise da estabilidade à $2-8^{\circ} \mathrm{C}$

4.3.3.2 Análise da estabilidade em soro humano à $37^{\circ} \mathrm{C}$

4.3.4 Determinação do coeficiente de partição experimental dos derivados radiomarcados $(\mathrm{CP})$.

4.3.5 Estudos in vivo.

4.3.5.1 Estudos de biodistribuição em camundongos Balb-c sadios.

4.3.5.2 Estudos farmacocinéticos em camundongos Balb-c sadios.

4.3.5.3 Estudos de corpo inteiro em camundongos Balb-c sadios.

4.3.5.4 Estudos de biodistribuição em camundongos Nude com tumor PC-3...

4.3.5.5 Estudos de competição em camundongos Nude com tumor PC-3.

4.3.5.6 Estudos de imagem.

4.3.6 Estudos in vitro

4.3.6.1 Efeito dos derivados da bombesina sobre a viabilidade metabólica das células PC-3.

4.3.7 Análise estatística.

5 RESULTADOS E DISCUSSÃO.

5.1 Radiomarcação com ${ }^{177} \mathrm{Lu}$ e determinação da pureza radioquímica dos derivados radiomarcados.

5.2 Análise da estabilidade dos derivados radiomarcados.

5.3 Determinação do coeficiente de partição experimental dos derivados radiomarcados $(\mathrm{CP})$.

5.4 Estudos in vivo. 84

5.4.1 Estudos de biodistribuição em camundongos Balb-c sadios. 
5.4.2 Estudos farmacocinéticos em camundongos Balb-c sadios.

5.4.3 Estudos de corpo inteiro em camundongos Balb-c sadios.

5.4.4 Estudos de imagem em camundongos Balb-c sadios

5.4.5 Estudos de biodistribuição em camundongos Nude com tumor PC-3.

5.4.6 Estudos de competição em camundongos Nude com tumor PC-3.

5.4.7 Estudos de imagem em camundongos Nude com tumor PC-3.

5.5 Estudos in vitro.

5.5.1 Efeito dos derivados da bombesina sobre a viabilidade metabólica das células PC-3.

6 CONCLUSÕES

6.1 Radiomarcação dos derivados da bombesina..

6.2 Estabilidade dos derivados da bombesina radiomarcados.

6.3 Lipossolubilidade dos derivados da bombesina radiomarcados.

6.4 Estudos in vivo em camundongos Balb-c.

6.5 Estudos in vivo em camundongos Nude implantados com tumor de células PC-3.

6.6 Atividade agonista ou antagonista dos derivados da bombesina.

6.7 Potencial dos derivados da bombesina para aplicação em diagnóstico e terapia de tumor de próstata. 


\section{LISTA DE TABELAS}

TABELA 1: Características físicas de radioisótopos aplicados em terapia.

TABELA 2: Características físicas de alguns emissores de partículas $\beta^{-}$.

TABELA 3: Pureza radioquímica e atividade específica após a radiomarcação de 20 $\mu \mathrm{g}$ dos derivados da bombesina com 2,5 mCi $(92,5 \mathrm{MBq})$ de ${ }^{177} \mathrm{LuCl}_{3}$ a $90^{\circ} \mathrm{C}$ por 30 minutos e $350 \mathrm{rpm}(\mathrm{n}=6)$. A pureza radioquímica foi analisada por cromatografia em camada delgada (ITLC-SG)

TABELA 4: Tempos de retenção do cloreto de lutécio-177 e dos derivados da bombesina não radiomarcados e radiomarcados em CLAE $(n=3)$. Os picos 1 e 2 correspondem à primeira e segunda espécies radioativas, respectivamente

TABELA 5: Estabilidade dos derivados radiomarcados com cloreto de lutécio-177 (ITLC-SG) após armazenamento à $2-8^{\circ} \mathrm{C}$ por diferentes tempos $(n=3)$. Os dados estão expressos em porcentagem de pureza radioquímica.

TABELA 6: Estabilidade metabólica dos derivados da bombesina radiomarcados em soro humano à $37^{\circ} \mathrm{C}(\mathrm{n}=4)$.

TABELA 7: Coeficiente de partição (CP) óleo:água (n-octanol:água) dos derivados da bombesina radiomarcados com ${ }^{177} \mathrm{Lu}(\mathrm{n}=5)$.

TABELA 8: Biodistribuição do derivado da bombesina $\mathrm{BEFG}_{1}$ radiomarcado com lutécio-177 (0,185 MBq) em camundongos Balb-c machos sadios ( $\mathrm{n}=5)$.

TABELA 9: Biodistribuição do derivado da bombesina $\mathrm{BEFG}_{2}$ radiomarcado com lutécio-177 (0,185 MBq) em camundongos Balb-c machos sadios ( $\mathrm{n}=5)$.

TABELA 10: Biodistribuição do derivado da bombesina $\mathrm{BEFG}_{3}$ radiomarcado com lutécio-177 (0,185 MBq) em camundongos Balb-c machos sadios ( $\mathrm{n}=5)$.

TABELA 11: Biodistribuição do derivado da bombesina $B E_{4}$ radiomarcado com lutécio-177 (0,185 MBq) em camundongos Balb-c machos sadios $(\mathrm{n}=5)$.

TABELA 12: Biodistribuição do derivado da bombesina $\mathrm{BEFG}_{5}$ radiomarcado com lutécio-177 (0,185 MBq) em camundongos Balb-c machos sadios ( $\mathrm{n}=5)$.... 
TABELA 13: Parâmetros farmacocinéticos para os derivados da bombesina $B E F G_{1}$, $\mathrm{BEFG}_{2}, \mathrm{BEFG}_{3}, \mathrm{BEFG}_{4}$ e $\mathrm{BEFG}_{5}$ radiomarcados com ${ }^{177} \mathrm{Lu}$ determinados utilizando o programa Biexp

TABELA 14: Tempos de meia-vida dos derivados da bombesina radiomarcados em cada um dos compartimentos identificados a partir das curvas de clareamento sanguíneo.

TABELA 15: Porcentagem da atividade dos derivados da bombesina excretada ao longo do tempo decorrido após a administração endovenosa

TABELA 16: Valores de porcentagem de atividade por grama de tumor em função da atividade injetada e da atividade retida no organismo em cada tempo

TABELA 17: Razões tumor:tecidos calculadas para os diferentes derivados da bombesina estudados. Os valores utilizados para os cálculos foram os \% AI/g obtidos a partir da biodistribuição dos derivados em camundongos Nude implantados com células PC-3.

TABELA 18: Captação tumoral, em \% AI/g, após uma hora da administração dos derivados da bombesina radiomarcados na ausência e presença do respectivo derivado não radiomarcado (bloqueador). 


\section{LISTA DE FIGURAS}

FIGURA 1: Sequência de aminoácidos da bombesina.

FIGURA 2: Desenho esquemático do sistema genital masculino.

FIGURA 3: Estrutura da bombesina.

FIGURA 4: Sequência dos grupamentos C-terminal da bombesina, do peptídeo liberador de gastrina e da neuromedina $\mathrm{B}$

FIGURA 5: Estrutura do derivado MP2346, em que M é o radiometal.

FIGURA 6: Derivados da bombesina com diferentes tipos de espaçadores e ligados ao agente quelante $\mathrm{N}_{3} \mathrm{~S}$

FIGURA 7: Espaçadores orgânicos de derivados da bombesina complexados ao DOTA e estudados por Parry e colaboradores (2007a).

FIGURA 8: Estrutura do AMBA- ${ }^{177} \mathrm{Lu}$

FIGURA 9: Espaçadores aminoacídicos de derivados da bombesina estudados por Parry e colaboradores (2007b)

FIGURA 10: Esquema do planejamento experimental deste trabalho.

FIGURA 11: Estrutura do derivado DOTA-Phe-(Gly) ${ }_{1}$-Asn-Gln-Trp-Ala-Val-GlyHis-Leu-Met- $\mathrm{NH}_{2}\left(\mathrm{BEFG}_{1}\right)$ após a complexação com ${ }^{177} \mathrm{Lu}$

FIGURA 12: Estrutura do derivado DOTA-Phe-(Gly) ${ }_{2}$-Asn-Gln-Trp-Ala-Val-GlyHis-Leu-Met- $\mathrm{NH}_{2}\left(\mathrm{BEFG}_{2}\right)$ após a complexação com ${ }^{177} \mathrm{Lu}$...

FIGURA 13: Estrutura do derivado DOTA-Phe-(Gly) ${ }_{3}$-Asn-Gln-Trp-Ala-Val-GlyHis-Leu-Met- $\mathrm{NH}_{2}\left(\mathrm{BEFG}_{3}\right)$ após a complexação com ${ }^{177} \mathrm{Lu}$.

FIGURA 14: Estrutura do derivado DOTA-Phe-(Gly) ${ }_{4}$-Asn-Gln-Trp-Ala-Val-GlyHis-Leu-Met- $\mathrm{NH}_{2}\left(\mathrm{BEFG}_{4}\right)$ após a complexação com ${ }^{177} \mathrm{Lu}$

FIGURA 15: Estrutura do derivado DOTA-Phe-(Gly) ${ }_{5}$-Asn-Gln-Trp-Ala-Val-GlyHis-Leu-Met- $\mathrm{NH}_{2}\left(\mathrm{BEFG}_{5}\right)$ após a complexação com ${ }^{177} \mathrm{Lu}$

FIGURA 16: Foto de microscópio óptico das células PC-3 derivadas de adenocarcinoma de próstata humano em $80 \%$ de confluência na placa de cultura (Aumento: $10000 \mathrm{x}$ ). 
FIGURA 17: Camundongo Nude com adenocarcinoma de próstata humano três semanas após o implante de 2 x $10^{6}$ células PC-3 por via subcutânea

FIGURA 18: Reação de redução do MTS a formazan.

FIGURA 19: Variação da pureza radioquímica das reações (ITLC-SG) em função da atividade de ${ }^{177} \mathrm{LuCl}_{3}(\mathrm{MBq})$ e da massa do derivado da bombesina $\mathrm{BEFG}_{3}(\mu \mathrm{g})$ que reagiram a $90^{\circ} \mathrm{C}$ por 30 minutos sob agitação de $350 \mathrm{rpm}(\mathrm{n}=3)$.

FIGURA 20: Perfil de CLAE (radioativo) do ${ }^{177} \mathrm{LuCl}_{3}$, utilizando-se uma coluna $\mathrm{C}_{18}$, com um gradiente linear de 10 a $90 \%$ de TFA: $\mathrm{CH}_{3} \mathrm{CN}(1: 1000 \mathrm{v} / \mathrm{v}) \mathrm{em}$ TFA: $\mathrm{H}_{2} \mathrm{O}(1: 1000 \mathrm{v} / \mathrm{v})$ a um fluxo de $1,5 \mathrm{~mL} /$ minuto por 15 minutos

FIGURA 21: Perfil de CLAE (radioativo) do $\mathrm{BEFG}_{1^{-}}{ }^{177} \mathrm{Lu}$, utilizando-se uma coluna $\mathrm{C}_{18}$, com um gradiente linear de 10 a $90 \%$ de $\mathrm{TFA}: \mathrm{CH}_{3} \mathrm{CN}(1: 1000 \mathrm{v} / \mathrm{v}) \mathrm{em}$ TFA: $\mathrm{H}_{2} \mathrm{O}(1: 1000 \mathrm{v} / \mathrm{v})$ a um fluxo de $1,5 \mathrm{~mL} /$ minuto por 15 minutos.

FIGURA 22: Perfil de CLAE (radioativo) do $\mathrm{BEFG}_{2}{ }^{-}{ }^{177} \mathrm{Lu}$, utilizando-se uma coluna $\mathrm{C}_{18}$, com um gradiente linear de 10 a 90\% de TFA: $\mathrm{CH}_{3} \mathrm{CN}(1: 1000 \mathrm{v} / \mathrm{v}) \mathrm{em}$ TFA: $\mathrm{H}_{2} \mathrm{O}(1: 1000 \mathrm{v} / \mathrm{v})$ a um fluxo de $1,5 \mathrm{~mL} /$ minuto por 15 minutos

FIGURA 23: Perfil de CLAE (radioativo) do $\mathrm{BEFG}_{3}{ }^{-177} \mathrm{Lu}$, utilizando-se uma coluna $\mathrm{C}_{18}$, com um gradiente linear de 10 a 90\% de TFA: $\mathrm{CH}_{3} \mathrm{CN}(1: 1000 \mathrm{v} / \mathrm{v}) \mathrm{em}$ TFA: $\mathrm{H}_{2} \mathrm{O}(1: 1000 \mathrm{v} / \mathrm{v})$ a um fluxo de $1,5 \mathrm{~mL} /$ minuto por 15 minutos.

FIGURA 24: Perfil de CLAE (radioativo) do $\mathrm{BEFG}_{4}{ }^{-177} \mathrm{Lu}$, utilizando-se uma coluna $\mathrm{C}_{18}$, com um gradiente linear de 10 a 90\% de TFA: $\mathrm{CH}_{3} \mathrm{CN}(1: 1000 \mathrm{v} / \mathrm{v}) \mathrm{em}$ TFA: $\mathrm{H}_{2} \mathrm{O}(1: 1000 \mathrm{v} / \mathrm{v})$ a um fluxo de $1,5 \mathrm{~mL} /$ minuto por 15 minutos

FIGURA 25: Perfil de CLAE (radioativo) do $\mathrm{BEFG}_{5}{ }^{-177} \mathrm{Lu}$, utilizando-se uma coluna $\mathrm{C}_{18}$, com um gradiente linear de 10 a 90\% de TFA: $\mathrm{CH}_{3} \mathrm{CN}(1: 1000 \mathrm{v} / \mathrm{v}) \mathrm{em}$ TFA: $\mathrm{H}_{2} \mathrm{O}(1: 1000 \mathrm{v} / \mathrm{v})$ a um fluxo de $1,5 \mathrm{~mL} /$ minuto por 15 minutos

FIGURA 26: Perfil de CLAE dos derivados da bombesina $\mathrm{BEFG}_{1}(\mathrm{~A}), \mathrm{BEFG}_{2}(\mathrm{~B})$, $\mathrm{BEFG}_{3}(\mathrm{C}), \mathrm{BEFG}_{4}(\mathrm{D}), \mathrm{BEFG}_{5}$ (E) e do veículo em que foram diluídos (F), utilizando-se uma coluna $\mathrm{C}_{18}$, com um gradiente linear de 10 a $90 \%$ de TFA: $\mathrm{CH}_{3} \mathrm{CN}$ $(1: 1000 \mathrm{v} / \mathrm{v})$ em TFA: $\mathrm{H}_{2} \mathrm{O}(1: 1000 \mathrm{v} / \mathrm{v})$ a um fluxo de $1,5 \mathrm{~mL} / \mathrm{minuto}$ por 15 minutos e sistema de detecção UV

FIGURA 27: Estrutura do aminoácido glicina.

FIGURA 28: Estrutura do aminoácido fenilalanina. 
FIGURA 29: Perfil cromatográfico dos derivados da bombesina radiomarcados com ${ }^{177} \mathrm{Lu}$ e do radiolantanídeo não ligado em ITLC-SG após incubação em soro humano à $37^{\circ} \mathrm{C}$

FIGURA 30: Curvas farmacocinéticas do $\mathrm{BEFG}_{1}, \mathrm{BEFG}_{2}, \mathrm{BEFG}_{3}, \mathrm{BEFG}_{4}$ e $\mathrm{BEFG}_{5}$ radiomarcados com ${ }^{177} \mathrm{Lu}(\mathrm{n}=5)$.....

FIGURA 31: Principais compartimentos do organismo nos quais os derivados da bombesina radiomarcados estão distribuídos.

FIGURA 32: Estudo de corpo inteiro dos derivados da bombesina radiomarcados com ${ }^{177}$ Lu em camundongos Balb-c $(\mathrm{n}=4)$.

FIGURA 33: Imagens cintilográficas do derivado da bombesina $\mathrm{BEFG}_{1^{-}}{ }^{177} \mathrm{Lu} \mathrm{em}$ camundongos Balb-c machos.

FIGURA 34: Imagens cintilográficas do derivado da bombesina $\mathrm{BEFG}_{2}{ }^{-}{ }^{177} \mathrm{Lu}$ em camundongos Balb-c machos.

FIGURA 35: Imagens cintilográficas do derivado da bombesina $\mathrm{BEFG}_{3^{-}}{ }^{177} \mathrm{Lu}$ em camundongos Balb-c machos.

FIGURA 36: Imagens cintilográficas do derivado da bombesina $\mathrm{BEFG}_{4^{-}}{ }^{177} \mathrm{Lu} \mathrm{em}$ camundongos Balb-c machos.

FIGURA 37: Imagens cintilográficas do derivado da bombesina $\mathrm{BEFG}_{5^{-}}{ }^{177} \mathrm{Lu}$ em camundongos Balb-c machos.

FIGURA 38: Corte de tumor de células PC-3, induzido em camundongos Nude, mostrando o epitélio, o tecido conjuntivo denso corado em róseo pela eosina e composto por fibras colágenas delicadas e o tecido conjuntivo frouxo, formado pela substância fundamental amorfa, em imagem negativa, e por glândulas ligeiramente basófilas. Logo abaixo, pode-se visualizar a formação tumoral envolta por uma cápsula (Aumento: 100x)

FIGURA 39: Corte de tumor de células PC-3, mostrando a cápsula acidófila que envolve o tumor, formada por células e fibras colágenas, e as células tumorais, de citoplasma ligeiramente basófilo (Aumento: 400x).....

FIGURA 40: Corte de tumor de células PC-3, mostrando a alta densidade de células pouco diferenciadas, de citoplasma ligeiramente basófilo, sustentadas por tecido conjuntivo (acidófilo) e apresentando crescimento desorganizado (Aumento: 400x). 
FIGURA 41: Cinética dos derivados da bombesina radiomarcados com ${ }^{177} \mathrm{Lu}$ em adenocarcinoma de próstata humano (PC-3) implantado em camundongos Nude. Os dados estão expressos em porcentagem da atividade injetada por grama de tumor $(\mathrm{n}=3)$

FIGURA 42: Cinética dos derivados da bombesina radiomarcados com ${ }^{177} \mathrm{Lu}$ no pâncreas de camundongos Nude com tumor PC-3 (n=3). Os dados estão expressos em porcentagem da atividade injetada por grama de tecido

FIGURA 43: Cinética dos derivados da bombesina radiomarcados com ${ }^{177} \mathrm{Lu}$ nos intestinos (com conteúdo) de camundongos Nude com tumor PC-3 ( $\mathrm{n}=3)$. Os dados estão expressos em porcentagem da atividade injetada por grama de tecido.

FIGURA 44: Cinética sanguínea dos derivados da bombesina radiomarcados com ${ }^{177} \mathrm{Lu}$ em camundongos Nude com tumor PC-3 (n=3). Os dados estão expressos em porcentagem da atividade injetada por mililitro de sangue.

FIGURA 45: Cinética dos derivados da bombesina radiomarcados com ${ }^{177} \mathrm{Lu}$ nos rins de camundongos Nude com tumor PC-3 $(n=3)$. Os dados estão expressos em porcentagem da atividade injetada por grama de tecido

FIGURA 46: Cinética dos derivados da bombesina radiomarcados com ${ }^{177} \mathrm{Lu}$ no fígado de camundongos Nude com tumor PC-3 ( $\mathrm{n}=3)$. Os dados estão expressos em porcentagem da atividade injetada por grama de tecido

FIGURA 47: Captação óssea dos derivados da bombesina radiomarcados com ${ }^{177} \mathrm{Lu}$ em camundongos Nude com tumor PC-3 (n=3). Os dados estão expressos em porcentagem da atividade injetada no osso total.

FIGURA 48: Cinética dos derivados da bombesina radiomarcados com ${ }^{177} \mathrm{Lu}$ na próstata de camundongos Nude com tumor PC-3 $(\mathrm{n}=3)$. Os dados estão expressos em porcentagem da atividade injetada na próstata..

FIGURA 49: Cinética dos derivados da bombesina radiomarcados com ${ }^{177} \mathrm{Lu}$ no coração de camundongos Nude com tumor PC-3 ( $\mathrm{n}=3)$. Os dados estão expressos em porcentagem da atividade injetada por grama de tecido

FIGURA 50: Cinética dos derivados da bombesina radiomarcados com ${ }^{177} \mathrm{Lu}$ nos pulmões de camundongos Nude com tumor PC-3 (n=3). Os dados estão expressos em porcentagem da atividade injetada por grama de tecido 
FIGURA 51: Cinética dos derivados da bombesina radiomarcados com ${ }^{177} \mathrm{Lu}$ no estômago de camundongos Nude com tumor PC-3 (n=3). Os dados estão expressos em porcentagem da atividade injetada por grama de tecido

FIGURA 52: Cinética dos derivados da bombesina radiomarcados com ${ }^{177} \mathrm{Lu}$ no baço de camundongos Nude com tumor PC-3 (n=3). Os dados estão expressos em porcentagem da atividade injetada por grama de tecido

FIGURA 53: Cinética dos derivados da bombesina radiomarcados com ${ }^{177} \mathrm{Lu}$ no músculo de camundongos Nude com tumor PC-3 (n=3). Os dados estão expressos em porcentagem da atividade injetada no músculo total.

FIGURA 54: Captação do $\mathrm{BEFG}_{4^{-}}{ }^{177} \mathrm{Lu}$ no tumor de células PC-3 e em alguns tecidos na ausência e na presença do bloqueador $\left(100 \mu \mathrm{g}\right.$ de $\left.\mathrm{BEFG}_{4}\right)$

FIGURA 55: Captação do $\mathrm{BEFG}_{5^{-}}{ }^{177} \mathrm{Lu}$ no tumor de células PC-3 e em alguns tecidos na ausência e na presença do bloqueador $\left(100 \mu \mathrm{g}\right.$ de $\left.\mathrm{BEFG}_{5}\right)$

FIGURA 56: Imagem cintilográfica de tumor de células PC-3 diferentes tempos após a administração de $37 \mathrm{MBq}(1 \mathrm{mCi})$ do derivado da bombesina $\mathrm{BEFG}_{1^{-}}{ }^{177} \mathrm{Lu}$ em camundongos $\mathrm{Nude}$.

FIGURA 57: Imagem cintilográfica de tumor de células PC-3 diferentes tempos após a administração de $37 \mathrm{MBq}(1 \mathrm{mCi})$ do derivado da bombesina $\mathrm{BEFG}_{2}{ }^{177} \mathrm{Lu}$ em camundongos $\mathrm{Nude}$.

FIGURA 58: Imagem cintilográfica de tumor de células PC-3 diferentes tempos após a administração de $37 \mathrm{MBq}(1 \mathrm{mCi})$ do derivado da bombesina $\mathrm{BEFG}_{3}{ }^{177} \mathrm{Lu}$ em camundongos Nude.

FIGURA 59: Imagem cintilográfica de tumor de células PC-3 diferentes tempos após a administração de $37 \mathrm{MBq}(1 \mathrm{mCi})$ do derivado da bombesina $\mathrm{BEFG}_{4^{-}}{ }^{177} \mathrm{Lu}$ em camundongos $\mathrm{Nude}$.

FIGURA 60: Imagem cintilográfica de tumor de células PC-3 diferentes tempos após a administração de $37 \mathrm{MBq}(1 \mathrm{mCi})$ do derivado da bombesina $\mathrm{BEFG}_{5^{-}}{ }^{177} \mathrm{Lu}$ em camundongos $N u d e$

FIGURA 61: Efeito de diferentes concentrações dos derivados da bombesina sobre a proliferação das células PC-3 in vitro após 72 horas de incubação. 


\section{LISTA DE ABREVIATURAS}

Ala

AMBA

AMP

Arg

Asn

Asp

$\mathbf{B B}_{3}$

$\mathbf{B B}_{4}$

BBN

BBN(6-14)

BBN(7-14)

BEFG $_{1}$

$\mathrm{BEFG}_{2}$

$\mathrm{BEFG}_{3}$

$\mathrm{BEFG}_{4}$

BEFG $_{5}$

BZH1

BZH2

CE

Cha

$\mathrm{CH}_{3} \mathrm{CN}$

CI

CLAE

CP

Cys

d

DHT
Alanina

DO3A-CH $\mathrm{CH}_{2} \mathrm{CO}-\mathrm{Gly}-4$-aminobenzoil-BBN(7-14)

Monofosfato de adenosine

Arginina

Asparagina

Ácido aspártico

Receptor órfão para a bombesina

Receptor para a bombesina descrito apenas em anfíbios

Bombesina

Sequência de aminoácidos da bombesina do aminoácido 6 (Asn) ao aminoácido 14 (Met)

Sequência de aminoácidos da bombesina do aminoácido 7 (Gln) ao aminoácido 14 (Met)

DOTA-Phe-(Gly) ${ }_{1}$-Asn-Gln-Trp-Ala-Val-Gly-His-Leu-Met- $\mathrm{NH}_{2}$

DOTA-Phe-(Gly) ${ }_{2}$-Asn-Gln-Trp-Ala-Val-Gly-His-Leu-Met- $\mathrm{NH}_{2}$

DOTA-Phe-(Gly) ${ }_{3}$-Asn-Gln-Trp-Ala-Val-Gly-His-Leu-Met-NH ${ }_{2}$

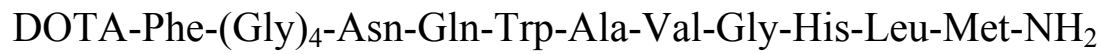

DOTA-Phe-(Gly) ${ }_{5}$-Asn-Gln-Trp-Ala-Val-Gly-His-Leu-Met- $\mathrm{NH}_{2}$

GABA-[D-Tyr ${ }^{6}$, b-Ala $\left.^{11}, \mathrm{Thi}^{13} ; \mathrm{Nle}^{14}\right]$-BBN(6-14)-DTPA

GABA-[D-Tyr ${ }^{6}$, b-Ala $^{11}$, Thi $\left.^{13} ; \mathrm{Nle}^{14}\right]$-BBN(6-14)-DOTA

Captura eletrônica

Ciclohexilalanina

Acetonitrila

Conversão interna

Cromatografia líquida de alta eficiência

Coeficiente de partição

Cisteína

Dias

Diidrotestosterona 


\begin{tabular}{|c|c|}
\hline DOTA & Ácido 1,4,7,10-tetraazaciclododecano-tetraacético \\
\hline DTMA & Ácido 2-N,N'-Bis-terc-butoxicarbonil-dietilenotriaminoacético \\
\hline DTPA & Ácido dietilenotriaminopentacético \\
\hline EDTMP & Ácido etileno-diamino-tetrametileno fosfônico \\
\hline g & Força centrífuga \\
\hline GABA & Ácido gama-aminobutírico \\
\hline Gln & Glutamina \\
\hline Glu & Ácido glutâmico \\
\hline Gly & Glicina \\
\hline GRP & Peptídeo liberador de gastrina \\
\hline GRPr & Receptor para peptídeo liberador de gastrina \\
\hline h & Horas \\
\hline His & Histidina \\
\hline HYNIC & Ácido 6-hidrazinopiridina-3-carboxílico \\
\hline Ile & Isoleucina \\
\hline IPEN & Instituto de Pesquisas Energéticas e Nucleares \\
\hline $\mathbf{K}$ & Constante de transferência \\
\hline $\mathbf{K}_{10}$ & Constante de transferência do espaço vascular para o sistema excretor \\
\hline $\mathbf{K}_{12}$ & Constante de transferência do espaço vascular para o extravascular \\
\hline $\mathbf{K}_{21}$ & Constante de transferência do espaço extravascular para o vascular \\
\hline $\mathbf{K}_{\mathrm{ss}}$ & Constante de eliminação \\
\hline Leu & Leucina \\
\hline LH & Hormônio luteinizante \\
\hline LHRH & Hormônio liberador do hormônio luteinizante \\
\hline Lys & Lisina \\
\hline $\mathbf{M}$ & Molar $\left(\mathrm{mol}^{-L^{-1}}\right)$ \\
\hline Met & Metionina \\
\hline MIBG & Metaiodobenzilguanidina \\
\hline $\min$ & Minutos \\
\hline MTS & $\begin{array}{l}\text { 3(4,5-dimetiltiazol-2-il)-5(3-carboximetoxifenil)-2-(4-sulfofenil)-2H- } \\
\text { tetrazolina }\end{array}$ \\
\hline Nle & Norleucina \\
\hline $\mathbf{n M}$ & Nanomolar \\
\hline NMB & Neuromedina B \\
\hline
\end{tabular}




\begin{tabular}{|c|c|}
\hline NMBr & Receptor para neuromedina B \\
\hline $\mathbf{N}_{3} \mathbf{S}$ & Dimetilglicil-L-seril-L-cisteinilglicinamida \\
\hline PC-3 & Linhagem celular de adenocarcinoma de próstata humano \\
\hline PET & Tomografia por emissão de pósitron \\
\hline Phe & Fenilalanina \\
\hline PBS & Tampão fosfato-salino pH 7,4 \\
\hline Pro & Prolina \\
\hline PSA & Antígeno prostático específico \\
\hline $\mathbf{R}_{\mathbf{f}}$ & Fator de retenção \\
\hline rpm & Rotações por minuto \\
\hline SBCAL & Sociedade Brasileira de Ciência em Animais de Laboratório \\
\hline Ser & Serina \\
\hline SFB & Soro fetal bovino \\
\hline SPECT & Tomografia por emissão de fóton único \\
\hline TFA & Ácido trifluoroacético \\
\hline Thr & Treonina \\
\hline TR & Tempo de retenção \\
\hline Trp & Triptofano \\
\hline TSH & Hormônio estimulador da função tireoidiana \\
\hline Tyr & Tirosina \\
\hline $\mathbf{T}_{1 / 2}$ & Tempo de meia-vida \\
\hline T47-D & Linhagem celular de carcinoma de mama humano \\
\hline UV & Ultravioleta \\
\hline Val & Valina \\
\hline${ }^{32} \mathbf{P}$ & Radioisótopo de fósforo com número de massa 32 \\
\hline${ }^{64} \mathrm{Cu}$ & Radioisótopo de cobre com número de massa 64 \\
\hline${ }^{67} \mathrm{Ga}$ & Radioisótopo de gálio com número de massa 67 \\
\hline${ }^{68} \mathrm{Ga}$ & Radioisótopo de gálio com número de massa 68 \\
\hline${ }^{86} \mathbf{Y}$ & Radioisótopo de ítrio com número de massa 86 \\
\hline${ }^{90} \mathbf{Y}$ & Radioisótopo de ítrio com número de massa 90 \\
\hline${ }^{99 m_{T c}}$ & Radioisótopo de tecnécio metaestável com número de massa 99 \\
\hline${ }^{111}$ In & Radioisótopo de índio com número de massa 111 \\
\hline${ }^{125} \mathbf{I}$ & Radioisótopo de iodo com número de massa 125 \\
\hline${ }^{131} \mathbf{I}$ & Radioisótopo de iodo com número de massa 131 \\
\hline
\end{tabular}


${ }^{153} \mathrm{Sm} \quad$ Radioisótopo de samário com número de massa 153

${ }^{177} \mathbf{L u} \quad$ Radioisótopo de lutécio com número de massa 177

${ }^{188} \mathbf{R e} \quad$ Radioisótopo de rênio com número de massa 177

${ }^{201}$ Tl Radioisótopo de tálio com número de massa 201

5-Ava Ácido 5-aminovalérico

8-Aoc Ácido 8-aminooctanóico

11-Aun Ácido 11-aminoundecanóico

\% AI Porcentagem da atividade injetada em um determinado tecido

\% AI/g Porcentagem da atividade injetada em um grama de um determinado tecido

$\% \mathbf{A I} / \mathbf{m L} \quad$ Porcentagem da atividade injetada em um mililitro de sangue

\% ARO/g Porcentagem da atividade total retida no organismo em um grama de tecido 


\section{INTRODUÇÃO}

Segundo o Instituto Nacional do Câncer (2009), o câncer de próstata é o segundo tipo de câncer mais frequente em homens no Brasil, o sexto mais comum no mundo e o mais prevalente em homens, representando cerca de $10 \%$ do total diagnosticado. Quando o tumor for localizado na sua fase inicial, a prostectomia radical ou a radioterapia aumentam a possibilidade de cura do paciente. No entanto, os tratamentos quimioterápico, radioterápico e cirúrgico tornam-se pouco efetivos nos casos em que há metástases e o tumor pode evoluir para um estado hormônio-refratário (hormônioresistente), caracterizado por altas morbidade e mortalidade (Lantry et al., 2006). Sendo assim, novas estratégias de diagnóstico e tratamento precisam ser investigadas e, a terapia radioisotópica surgiu nesse contexto como uma técnica promissora para melhoria do prognóstico dos pacientes (Prasanphanic et al., 2007).

Radiofármacos para terapia radioisotópica são desenvolvidos para conduzir por via endovenosa uma dose de radiação terapêutica a sítios específicos, como, por exemplo, células tumorais. Na célula alvo, a radiação ionizante (partículas $\alpha$ ou $\beta^{-}$) pode danificar componentes celulares e levar à morte celular de forma direta, por quebra do DNA, ou indireta, via radicais livres $\left(\mathrm{OH}^{\circ}, \mathrm{H}^{\circ}, \mathrm{O}_{2}{ }^{-}\right)$formados pela interação da radiação com a água no tecido alvo (Chen et al., 2008). O desenvolvimento de radiofármacos para terapia radioisotópica envolve duas etapas: a escolha do radioisótopo e da substância a ser radiomarcada (Zalutsky, 2003).

O lutécio-177 $\left({ }^{177} \mathrm{Lu}\right)$ tem emergido como um promissor agente emissor de partículas $\beta^{-}$de baixo alcance para essa classe de procedimento. $O$ alcance máximo das partículas $\beta^{-}$emitidas pelo ${ }^{177} \mathrm{Lu}$ é $1,8 \mathrm{~mm}$ e seu tempo de meia-vida é 6,7 dias, o que o torna adequado para o tratamento de micrometástases, como as causadas por tumores de próstata hormônio-refratários. Além disso, devido à emissão concomitante de raios $\gamma$ de $208 \mathrm{keV}$, moléculas marcadas com esse radioisótopo podem também ser utilizadas como ferramentas no diagnóstico por imagem (Mikolajczak et al., 2003).

A bombesina (BBN, FIG. 1), um peptídeo de 14 aminoácidos análogo dos peptídeos humanos liberador de gastrina (GRP) e neuromedina B (NMB) (Stangelberger et 
al., 2008), foi isolada da pele do anfíbio Bombina bombina em 1970 (Anastasi et al., 1970). $\mathrm{A} \mathrm{BBN}$ exerce seus efeitos nas células alvo através da ligação a receptores acoplados à proteína $\mathrm{G}$, conhecidos por possuírem sete domínios transmembrana. Atualmente, existem três tipos de receptores para $\mathrm{BBN}$ descritos em mamíferos, sendo eles o receptor para $\mathrm{NMB}(\mathrm{NMBr})$, o receptor para GRP (GRPr) e o receptor órfão $\mathrm{BB}_{3}$, assim denominado por se desconhecer seu ligante endógeno. A ativação desses receptores desencadeia uma série de funções fisiológicas, dentre elas liberação de hormônios gastrointestinais, estimulação da função pancreática e efeitos no sistema nervoso central, tais como termorregulação e inibição do hormônio estimulador da função tireoidiana (Durkan et al., 2007). O interesse em derivados da bombesina radiomarcados para diagnóstico e/ou terapia radioisotópica de tumores tem crescido consideravelmente a partir da observação de que GRPr são superexpressos em alguns tipos de células tumorais, dentre elas as do adenocarcinoma de próstata humano (Chen et al., 2008). Nesse caso, a interação do GRPr com seu ligante está diretamente relacionada à atividade proliferativa das células tumorais (Patel et al., 2006; Zhu et al., 2007).

\section{pGlu-Gln-Arg-Leu-Gly-Asn-GIn-Trp-Ala-Val-Gly-His-Leu-Met-CONH 2}

FIGURA 1 - Sequência de aminoácidos da bombesina.

Modificações moleculares na estrutura da BBN vêm sendo promovidas a fim de melhorar sua afinidade pelos receptores e especificidade pelas células tumorais. Essas modificações ocorrem principalmente na sua porção N-terminal da BBN, uma vez que a porção C-terminal é a responsável pela interação com os receptores e atividade biológica do peptídeo (Varvarigou et al., 2004). Os derivados produzidos podem ser agonistas ou antagonistas dos GRPr e têm sido radiomarcados com diferentes radioisótopos para diagnóstico e terapia de tumor de próstata (Hu et al., 2002; Zhang et al., 2004; Stangelberger et al., 2005; Prasanphanic et al., 2007; Lane et al., 2008). Dentre eles, os derivados radiomarcados com lutécio-177 têm apresentado resultados promissores em estudos pré-clínicos (Johnson et al., 2006; Lantry et al., 2006; Zhang et al., 2007). No entanto, todos os derivados estudados apresentaram alta captação no pâncreas e no intestino, tecidos que apresentam alta densidade de GRPr. Esse achado é a principal limitação do uso clínico da BBN, devido aos efeitos adversos acarretados pela dose de radiação absorvida por esses tecidos. Portanto, outras modificações moleculares na 
estrutura da bombesina são necessárias para a obtenção de um radiofármaco mais seletivo para a aplicação clínica. 


\section{OBJETIVOS}

\subsection{Objetivo geral}

Radiomarcar uma nova série de derivados da bombesina com lutécio-177 e avaliar a relação entre a sua estrutura e o potencial diagnóstico-terapêutico através de uma análise comparativa de suas propriedades in vitro e in vivo, a fim de propor um radiofármaco em potencial para diagnóstico e terapia radioisotópica do câncer de próstata.

\subsection{Objetivos específicos}

$\checkmark$ Radiomarcar os derivados da bombesina com lutécio-177 com alta pureza radioquímica;

$\checkmark$ estudar a estabilidade dos derivados radiomarcados;

$\checkmark$ predizer comparativamente a lipossolubilidade dos derivados radiomarcados;

$\checkmark$ analisar sua biodistribuição, farmacocinética e via de excreção em camundongos normais, determinando os possíveis órgãos-alvo;

$\checkmark$ desenvolver um modelo animal de tumor de próstata;

$\checkmark$ comparar a ligação dos derivados da bombesina radiomarcados às células de tumor de próstata in vivo no modelo animal desenvolvido, de modo a relacioná-la com a estrutura do derivado;

$\checkmark$ analisar a especificidade da ligação dos derivados da bombesina às células tumorais in vivo;

$\checkmark$ avaliar a capacidade de detecção do tumor in vivo através de imagens cintilográficas;

$\checkmark$ predizer uma atividade agonista ou antagonista para os derivados estudados in vitro;

$\checkmark$ sugerir o(s) derivado(s) com maior potencial para aplicação em diagnóstico e em terapia de tumor de próstata. 


\section{REVISÃO BIBLIOGRÁFICA}

\subsection{Neoplasia}

Nos organismos multicelulares, a taxa de proliferação de cada tipo celular é controlada com precisão por um sistema altamente integrado que permite a sua replicação dentro de estreitos limites, mantendo a população normal em níveis homeostáticos. Como na maioria dos tecidos e órgãos há divisão celular contínua para restaurar as perdas decorrentes do processo de envelhecimento, a replicação celular é atividade essencial para o organismo. No entanto, ela deve seguir o controle rígido imposto ao sistema, pois se feita para mais ou para menos o equilíbrio se quebra. Uma das características principais das células neoplásicas é sua proliferação descontrolada.

A reprodução é atividade fundamental das células e, em geral, existe correlação inversa entre diferenciação e multiplicação celular. Quanto mais avançado ou complexo é o estado de diferenciação, menor é sua taxa de reprodução. Assim se entende que, nas neoplasias, ocorre também perda da diferenciação celular paralelamente ao aumento da taxa de proliferação.

A proliferação celular, em condições normais, é atividade complexa e depende da atuação coordenada dos produtos de vários genes, os quais controlam o processo em resposta a estímulos internos e externos (Brasileiro Filho, Guimarães e Bogliolo, 1998). Ao longo de sua existência, as células são expostas a agentes mutagênicos e sofrem erros de duplicação, resultando em alterações sutis e progressivas na sequência do DNA. Quanto maior o número de mitoses de uma célula, maior a chance de ocorrência de alterações no seu DNA. Eventualmente, uma dessas mutações somáticas pode alterar a função de um gene fundamental e fornecer uma vantagem no crescimento e multiplicação da célula mutante, permitindo a expansão do clone. Alterações adicionais em genes relevantes para a manutenção da integridade do genoma podem acelerar a taxa de mutações e levar ao surgimento de células mutantes capazes de proliferar desenfreadamente, invadir e colonizar diversas regiões do organismo (Ojopi e Neto, 2004). Portanto, a célula neoplásica sofre alteração intrínseca nos seus mecanismos regulatórios da multiplicação, adquire autonomia de crescimento e se torna independente dos controles externos. 
Feitas as considerações anteriores, as neoplasias podem ser entendidas como proliferações anormais de células que têm crescimento autônomo e tendem a perder sua diferenciação. O termo neoplasia significa literalmente o processo de um "novo crescimento", denominado neoplasma. Já o termo "tumor" foi originalmente aplicado ao edema causado por uma inflamação. Os neoplasmas também causam edemas, mas há muito tempo o emprego não-neoplásico de tumor saiu de uso. Oncologia (do grego oncos = tumor) é o estudo de tumores ou neoplasmas. Câncer é o termo comum para todos os tumores malignos (Robbins e Cotran, 2005). Cancerígeno ou oncogênico é o estímulo ou agente capaz de causar câncer (Brasileiro Filho, Guimarães e Bogliolo, 1998).

Embora o câncer seja uma doença complexa e o meio ambiente e fatores nãogenéticos desempenhem um papel importante em muitos estágios do processo neoplásico, as variedades dessas malignidades são promotoras de algum fator que descaracteriza o DNA. Essas alterações podem decorrer da expressão de genes associados, dos eventos mutacionais que alteram sua atividade e de eventos epigenéticos que alteram seu padrão de expressão (Ojopi e Neto, 2004).

\subsubsection{Classificação das neoplasias}

As neoplasias podem ser divididas em benignas e malignas, considerando-se seu comportamento e evolução. As neoplasias benignas geralmente não são letais nem causam sérios transtornos para o hospedeiro; por isso, podem evoluir durante muito tempo sem colocar em risco a vida de seu portador. Ao contrário, as neoplasias malignas têm crescimento acelerado e muitas provocam perturbações homeostáticas graves que acabam levando o paciente à morte (Brasileiro Filho, Guimarães e Bogliolo, 1998).

\subsubsection{Neoplasias benignas}

As células neoplásicas benignas em geral são bem diferenciadas e podem até ser indistinguíveis das células normais correspondentes. As atipias celulares e arquiteturais são discretas, ou seja, o tumor reproduz bem o tecido que lhe deu origem. Como a taxa de divisão celular é pequena, ou seja, o índice mitótico é baixo, o crescimento também é lento, o que permite o desenvolvimento adequado de vasos sanguíneos, assegurando a boa nutrição das células. Desse modo, degenerações, necrose e hemorragias são pouco comuns. Além disso, não compromete a nutrição do hospedeiro e nem produz substâncias que podem provocar anemia ou caquexia (Brasileiro Filho, Guimarães e Bogliolo, 1998). 
Nos tumores benignos as células crescem unidas entre si, não infiltram os tecidos vizinhos e formam uma massa geralmente esférica. Esse crescimento é dito expansivo e provoca compressão das estruturas adjacentes. Com frequência forma-se uma cápsula fibrosa em torno do tumor e a neoplasia fica bem delimitada, podendo ser completamente removida por cirurgia. Em geral, os tumores benignos não recidivam após ressecção cirúrgica (Brasileiro Filho, Guimarães e Bogliolo, 1998).

\subsubsection{Neoplasias malignas ou câncer}

As células das neoplasias malignas, também chamadas de células cancerosas, têm propriedades bioquímicas, morfológicas e funcionais variadas. Como sua taxa de multiplicação é elevada (alto índice mitótico), seu crescimento é usualmente rápido e o mesmo não acontece com o estroma e os vasos sanguíneos, que se desenvolvem mais lentamente, resultando muitas vezes em degenerações, necroses, hemorragias e ulcerações. Em razão da perda da diferenciação celular, as células malignas apresentam atipias variadas, desde discretas até muito intensas; neste caso perdem seus aspectos morfológicos específicos. As células cancerosas apresentam também alterações importantes da membrana plasmática, que as tornam menos aderentes entre si e facilitam seu deslocamento da colônia neoplásica. Com isso elas podem se movimentar, infiltrar-se em tecidos adjacentes, penetrar em vasos sanguíneos e linfáticos e, a partir deles, migrar para regiões distantes do organismo e neles originar novos tumores, denominados metástases. A formação de metástases é um processo complexo que depende de inúmeras interações entre células malignas e componentes do hospedeiro. Dele participam diversos produtos gênicos, sobretudo moléculas de adesão, enzimas hidrolíticas e fatores envolvidos na formação de vasos.

Devido ao crescimento infiltrativo, os limites do câncer com as estruturas adjacentes são pouco definidos e, como consequência, a remoção completa do tumor muitas vezes torna-se difícil. Em muitos casos, em torno da lesão principal existem ilhotas ou cordões de células neoplásicas que se proliferam, podendo dar origem a novos tumores. Por tudo isso a remoção cirúrgica é difícil e faz-se necessário retirar certa quantidade de tecido normal. Mesmo assim, o câncer tem tendência à recidiva (Brasileiro Filho, Guimarães e Bogliolo, 1998). 


\subsection{Próstata}

O aparelho reprodutor masculino é constituído pelos testículos, ductos genitais, glândulas acessórias e pênis (FIG. 2). O testículo tem a dupla função de produzir espermatozóides e testosterona, o hormônio sexual masculino. Os ductos genitais e as glândulas acessórias produzem secreções que, ajudadas pela contração da musculatura lisa, impulsionam os espermatozóides para o exterior. Essas secreções também oferecem nutrientes para os espermatozóides enquanto esses permanecem no sistema reprodutor masculino. As secreções e os espermatozóides constituem o sêmen ou esperma, que é expelido ou introduzido no aparelho reprodutor feminino pelo pênis. As glândulas acessórias são as vesículas seminais, a próstata (FIG. 2, em amarelo) e as glândulas bulbouretrais (Junqueira e Carneiro, 1999).

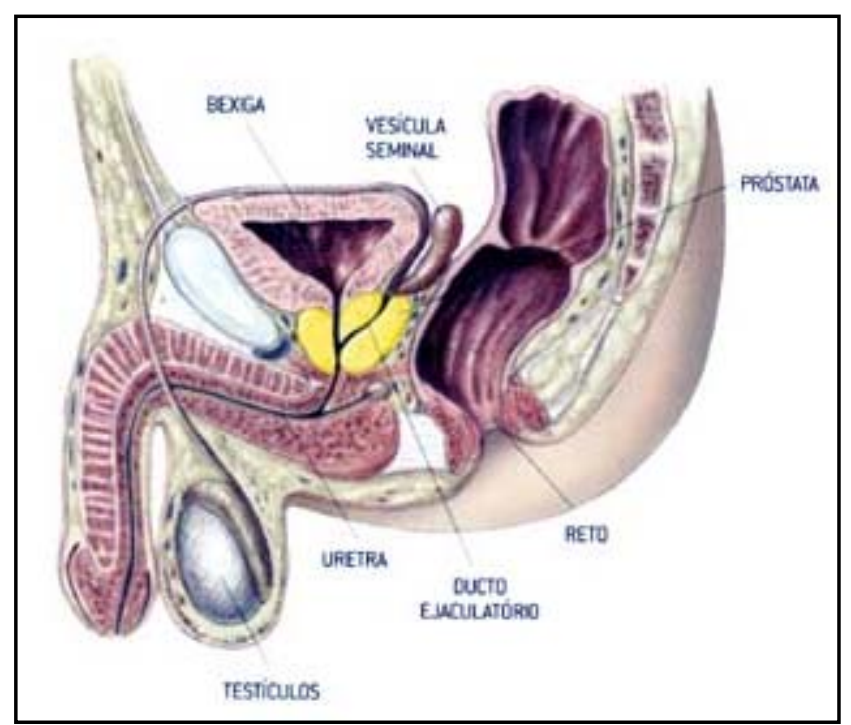

FIGURA 2 - Desenho esquemático do sistema genital masculino (Sistema Reprodutor Masculino, 2008). 


\subsubsection{Aspectos da normalidade}

A próstata é um órgão retroperitonial que circunda o colo vesical e a uretra e é desprovido de uma cápsula distinta. No adulto normal, a próstata pesa aproximadamente 20 gramas (Epstein, 2005).

A próstata pode ser dividida anatomicamente em lobos laterais, anterior, posterior e médio, divisão nítida somente no período embrionário. No adulto, o limite entre os lobos é impreciso, não existindo feixes de tecido conjuntivo que os delimitem. Além da divisão anatômica, a próstata pode também ser dividida em grupos glandulares internos e externos. Fazem parte do grupo glandular interno as glândulas mucosas e as submucosas e, do externo, as glândulas externas ou prostáticas propriamente ditas (Brasileiro Filho, 2000). Entre esse dois grupos glandulares há uma zona, conhecida como zona de transição. Setenta por cento da glândula é formado pelas glândulas externas, as quais correspondem à zona periférica prostática, e que apresentam um epitélio mais regular. Além disso, é o principal local de origem dos tumores de próstata. A zona de transição, embora muito pequena, é de extrema importância médica por ser o local onde se originam com frequência a maior parte das hiperplasias benignas da próstata. Esse conjunto de 30 a 50 glândulas tuboalveolares ramificadas, cujos ductos desembocam na uretra, é responsável pela produção e armazenamento do líquido prostático até a ejaculação (Junqueira e Carneiro, 1999).

As glândulas prostáticas são constituídas por ácinos e ductos excretores revestidos por células cúbicas ou cilíndricas altas. Os núcleos dessas células são basais e o citoplasma mostra, à imuno-histoquímica, forte positividade para antígeno específico da próstata (PSA). Abaixo dessas, há uma camada irregular de células basais, as quais atuam apenas como células de reserva e diferenciando-se em células epiteliais secretoras.

A próstata está sob influência hormonal. O hormônio luteinizante (LH), produzido na adeno-hipófise, por ação do hormônio liberador do LH (LHRH) sintetizado no hipotálamo, estimula as células de Leydig do testículo a produzir testosterona. $\mathrm{O}$ epitélio glandular prostático responde à ação da diidrotestosterona (DHT), que resulta da ação da enzima $5 \alpha$-redutase sobre a testosterona nas células estromais. A testosterona tem função na libido e potência sexual, enquanto a DHT atua no crescimento e função do epitélio glandular prostático. A falta desse hormônio promove a sua regressão (Brasileiro Filho, 2000).

Somente três processos patológicos afetam a próstata: inflamação, aumento nodular benigno e câncer. Destes três, os aumentos nodulares benignos são os mais 
comuns e ocorrem com tanta frequência na idade avançada que podem ser considerados um processo "natural" do envelhecimento. Os processos inflamatórios têm, na maior parte das vezes, pouca importância clínica e podem ser tratados facilmente. O carcinoma prostático, por sua vez, é também uma lesão comum, e, por sua gravidade, merece uma consideração cuidadosa (Robbins e Cotran, 2005).

\subsection{2 $O$ câncer de próstata}

Os termos "câncer de próstata" e "adenocarcinoma prostático", quando usados sem classificações, se referem à variante comum ou acinar do câncer de próstata (Epstein, 2005). O foco deste trabalho é essa variante.

Em aproximadamente $70 \%$ dos casos, o carcinoma de próstata surge na zona periférica da glândula, classicamente em uma localização posterior, frequentemente palpável ao exame retal. Caracteristicamente, aos cortes da próstata, o tecido neoplásico é áspero e firme, mas quando encrustado na substância prostática pode ser extremamente difícil de visualizar e mais aparente à palpação. A disseminação do câncer de próstata ocorre por invasão local direta e através da corrente sanguínea e linfática. A extensão local envolve mais comumente as vesículas seminais e a base da bexiga urinária, o que pode resultar em obstrução ureteral. A disseminação hematogênica ocorre principalmente para os ossos, particularmente o esqueleto axial, mas raramente algumas lesões se disseminam amplamente para as vísceras. Os ossos mais comumente envolvidos, em ordem decrescente de frequência, são a coluna lombar, o fêmur proximal, a pelve, a coluna torácica e as costelas. Já a disseminação linfática ocorre inicialmente para os linfonodos. A disseminação para linfonodos frequentemente precede a disseminação óssea (Epstein, 2005).

Em termos de valores absolutos, o câncer de próstata é o sexto tipo de malignidade mais comum no mundo e a mais prevalente em homens, representando cerca de $10 \%$ do total de câncer (Instituto Nacional do Câncer, 2009). É também a terceira causa de morte no mundo e o mais diagnosticado em homens nos países ocidentais (de Visser et al., 2007). As taxas de incidência desta patologia são cerca de seis vezes maiores nos países desenvolvidos comparados aos países em desenvolvimento. O número de casos novos de câncer de próstata estimados para o Brasil no ano de 2008 é de 49530, e o mesmo índice é válido para o ano de 2009. Estes valores correspondem a um risco estimado de 52 casos novos a cada 100 mil homens (Instituto Nacional do Câncer, 2009).

O câncer de próstata é tipicamente uma doença de homens com mais de 50 
anos de idade. Mais do que qualquer outro tipo de câncer, este é considerado o câncer da terceira idade, uma vez que cerca de três quartos dos casos no mundo ocorrem a partir dos 65 anos. O aumento que vem sendo observado nas taxas de incidência pode ter sido influenciado especialmente em regiões onde o rastreamento através do teste do Antígeno Prostático Específico (PSA) é comum. A mortalidade por câncer de próstata é relativamente baixa, o que reflete, em parte, seu bom prognóstico (Instituto Nacional do Câncer, 2009).

Pouco se sabe sobre as causas do câncer prostático. Fatores predisponentes ainda não estão bem elucidados, apesar dos inúmeros estudos em andamento. Diversos fatores de risco, como idade, raça, histórico familiar, níveis hormonais e influências ambientais parecem ter uma participação (Epstein, 2005).

A suspeita diagnóstica do câncer de próstata é feita pela observação isolada de níveis séricos elevados do antígeno prostático específico (PSA) ou de alterações texturais ao exame digital da próstata. Uma vez avaliados esses dois parâmetros, caso persista a hipótese de tumor, deverão ser solicitados estudo ultra-sonográfico por via transretal e biópsia, sendo esta última a única forma de diagnóstico definitivo de tumor. A associação dessas ferramentas é responsável pelo estadiamento local. Outros exames, como a tomografia computadorizada de pelve e a ressonância magnética auxiliam na busca de metástases nos linfonodos regionais e de doença extraprostática (Império, 2004).

Atualmente, cirurgia, radioterapia, quimioterapia e terapia hormonal são as opções de tratamento para o câncer de próstata. Essas opções variam com o estágio da doença e com a existência ou não de metástases. Tumores localizados podem ser tratados por cirurgia ou radioterapia, enquanto metástases requerem além da prostectomia radical, radioterapia do tumor primário, quimioterapia ou terapia hormonal com anti-androgênios. A maioria dos pacientes de câncer de próstata responde à terapia hormonal. No entanto, o maior problema no tratamento de tumores de próstata metastáticos é a transição de um estado hormônio sensível para hormônio resistente ou hormônio refratário, caracterizado pela ausência de resposta à terapia com anti-androgênios. Os mecanismos envolvidos nessa transição ainda não são bem compreendidos e o estado hormônio-refratário é caracterizado pela ausência de tratamento e por altas morbidade e mortalidade. Consequentemente, o diagnóstico precoce do câncer de próstata é necessário para garantir o bom prognóstico dos pacientes e o desenvolvimento de fármacos para tratamento do câncer de próstata hormônio-refratário é fundamental para melhoria na qualidade de vida dos pacientes (de Visser et al., 2007). 


\subsection{Medicina Nuclear e Radiofarmácia}

A imagem médica é baseada na interação da energia das radiações com os tecidos biológicos. A natureza da informação disponível em cada modalidade é determinada pela natureza dessas interações. A imagem convencional com os raios $\mathrm{X}$ permite a distinção do ar, água, gordura e osso devido ao coeficiente de absorção diferente para cada meio. Na ultrassonografia é a propriedade refletora diferente de cada tecido que serve de base para a construção da imagem. Nas imagens de ressonância magnética é a diferença de quantidade de hidrogênio existente no meio, além da química e física do núcleo de hidrogênio, que fornecem as bases para distinguir os tecidos (Thrall e Ziessman, 2003).

$\mathrm{Na}$ medicina nuclear a imagem do corpo é obtida de dentro para fora. Os radiotraçadores, geralmente na forma de radiofármacos, são administrados por via endovenosa, aguardando-se a concentração no tecido-alvo antes de adquirir as imagens (Sapienza e Buchpiguel, 2004). A inferência diagnóstica é obtida gravando-se a distribuição do material radioativo tanto no tempo quanto no espaço. A farmacocinética dos traçadores e a captação seletiva pelos tecidos formam as bases da utilidade diagnóstica (Thrall e Ziessman, 2003).

A riqueza das aplicações da medicina nuclear reside na diversidade de radiofármacos disponíveis. A maioria dos radiofármacos é uma combinação de um isótopo radioativo, que permite a detecção externa de uma porção biologicamente ativa, e de um fármaco, que é responsável pela biodistribuição. Para alguns agentes, tais como os gases inertes radioativos, os radioiodos $\left({ }^{131} \mathrm{I},{ }^{123} \mathrm{I}\right)$, o gálio-67 $\left({ }^{67} \mathrm{Ga}\right)$ na forma de citrato e o tálio$201\left({ }^{201} \mathrm{Tl}\right)$ na forma de cloreto, são os átomos em sua forma química adequada que possuem as propriedades desejadas para a localização, dispensando assim um componente químico maior (Thrall e Ziessman, 2003).

Certas características são desejáveis a um radiofármaco. O tipo, a energia e a meia-vida efetiva da emissão radioativa devem ser compatíveis com a aplicação desejada. A atividade específica, ou seja, a radioatividade por unidade de massa deve ser alta. Olhando pela perspectiva do fármaco, as características ideais incluem biodistribuição adequada para atingir o tecido alvo, ausência de toxicidade e efeitos secundários. Os radiofármacos não devem sofrer dissociação in vitro nem in vivo, devem estar facilmente disponíveis, ser fáceis de marcar e apresentar um custo razoável (Thrall e Ziessman, 2003).

A medicina nuclear permite caracterizar parâmetros funcionais e metabólicos in vivo e de forma não invasiva. As informações fornecidas podem auxiliar no raciocínio 
clínico em várias situações nas quais os métodos de imagem anatômicos são limitados, como, por exemplo, infiltração de pequenos linfonodos ou pesquisa de tumor residual após tratamento. As aplicações diagnósticas da medicina nuclear em oncologia incluem a deteç̧ão e caracterização da lesão primária, o estadiamento e o controle da resposta terapêutica. Dentre as aplicações terapêuticas da medicina nuclear em oncologia estão o tratamento de carcinoma diferenciado de tireóide com ${ }^{131} \mathrm{I}$, o tratamento de dores por metástases ósseas com o EDTMP ${ }^{153} \mathrm{Sm}$, o tratamento de tumores neuroectodérmicos com MIBG- ${ }^{131} \mathrm{I}$, a radioimuterapia, o tratamento de hepatocarcinoma com o lipiodol- ${ }^{131} \mathrm{I} \mathrm{e}$, mais recentemente, o tratamento de tumores neuroendócrinos com o Tyr ${ }^{3}$-Octreotato-DOTA ${ }^{177} \mathrm{Lu}$ (Sapienza e Buchpiguel, 2004). As aplicações terapêuticas da medicina nuclear serão consideradas detalhadamente mais adiante.

No Brasil, apesar de suas inúmeras aplicações no diagnóstico de patologias, no caso de tumores prostáticos, a medicina nuclear é utilizada apenas para avaliar suspeita de doença metastática óssea, através da cintilografia óssea com tecnécio-99m. Há também o ProstaScint- ${ }^{111}$ In, um conjugado do anticorpo monoclonal CYT-356, ligado a um agente quelante (GYK-DTA) e radiomarcado com ${ }^{111}$ In. O CYT-356 é uma imunoglobulina murina intacta que reage com o antígeno específico da membrana prostática, que é uma glicoproteína presente em mais de $95 \%$ dos adenocarcinomas de próstata. O ProstaScint-

${ }^{111}$ In foi aprovado em 1996 como um radiotraçador para detecção de metástases de partes moles em pacientes com carcinoma de próstata com alto risco para doença metastática. No entanto, esse radiofármaco não entrou na rotina clínica em medicina nuclear no Brasil e é muito pouco utilizado no mundo, provavelmente pelo clareamento sanguíneo lento, o que ocasiona aquisição de imagens tardias, dificuldade nos protocolos clínicos, baixas sensibilidade $(62 \%)$ e especificidade $(72 \%)$ e efeitos adversos reportados em $4 \%$ dos pacientes (Thrall e Ziessman, 2003).

\subsection{Terapia Radioisotópica}

A identificação de uma ferramenta simples para localizar e tratar neoplasias no estágio inicial do seu desenvolvimento tem sido um objetivo constante da classe médica, principalmente dos oncologistas. Nesse contexto, a investigação de características moleculares intrínsecas das células tumorais levou ao aprimoramento de fármacos receptor-específicos, utilizados em terapia molecular. Essa classe de fármacos pode apresentar atividade terapêutica intrínseca ou ainda carrear um agente citotóxico às células alvo e inclui anticorpos contra biomoléculas de superfície da célula tumoral e moléculas 
híbridas que consistem em ligantes receptor-específicos acoplados a radioisótopos, toxinas ou agentes quimioterápicos (Engel et al., 2007). Exemplos de fármacos receptorespecíficos são o anticorpo monoclonal Rituximab ${ }^{\circledR}$, utilizado no tratamento de linfoma, que se liga às moléculas $\mathrm{CD} 20$, marcadores protéicos presentes na superfície celular e relacionados à ativação, proliferação e diferenciação dos linfócitos B e o Octreotide ${ }^{\circledR}$, um octapeptídeo cíclico derivado da somatostatina, um peptídeo endógeno, que bloqueia receptores superexpressos em células de tumores neuroendócrinos (Thomas et al., no prelo).

Os efeitos tóxicos da radiação têm sido amplamente estudados e aplicados no tratamento de diversas condições patológicas, principalmente de neoplasias. Em geral, o tumor é irradiado por uma fonte externa de radiação (radioterapia) e em uma prática menos comum, denominada braquiterapia, em que a fonte radioativa encapsulada é implantada nas proximidades do tumor. Ainda que essas duas técnicas tenham sido efetivas no tratamento do câncer, elas apresentam propriedades intrínsecas que comprometem sua eficácia. Para o sucesso de sua utilização, radioterapia e braquiterapia exigem o conhecimento preciso da localização e configuração geométrica do tumor, a fim de maximizar a destruição das células tumorais e minimizar a radiação absorvida pelos tecidos adjacentes. Esses dois procedimentos são de limitada aplicação no tratamento de tumores multi-focais ou de sítios metastáticos e é para contornar essa limitação que a medicina nuclear tem direcionado seus esforços para a terapia radioisotópica ou radioterapia sistêmica (Zalutsky, 2003).

A terapia radioisotópica envolve a utilização de uma molécula radiomarcada que conduz seletivamente um nível citotóxico de radiação ao sítio tumoral. O objetivo dessa técnica é semelhante ao da radioterapia e braquiterapia: maximizar a dose de radiação absorvida pelo tumor e reduzir ao mínimo a irradiação dos órgãos normais. Além do efeito terapêutico, a utilização de isótopos radioativos permite a aquisição de imagem dos radioligantes acumulado no tumor e fornece informações úteis a respeito de sua interação e características bioquímicas das células tumorais. A terapia radioisotópica se difere da radioterapia e da braquiterapia quanto aos fatores que devem ser analisados para se atingir esse objetivo (Zalutsky, 2003).

A terapia radioisotópica vem sendo utilizada em pacientes há mais de sessenta anos com a aplicação clínica do iodeto de sódio radioativo $\left(\mathrm{Na}^{131} \mathrm{I}\right)$ no tratamento de hipertireoidismo e carcinoma de tireóide. O aprimoramento de técnicas de síntese de proteínas recombinantes e os avanços no entendimento da biologia de tumores conduziram 
a uma evolução na pesquisa e na aplicação clínica da terapia radioisotópica (Kassis e Adelstein, 2003). Sua aplicação mais recente veio com o sucesso clínico da substituição do radioisótopo ${ }^{111}$ In do Octreoscan ${ }^{\circledR}$, um peptídeo derivado da somatostatina utilizado para aquisição de imagens de tumores neuroendócrinos, por radioisótopos com aplicação terapêutica, tais como ${ }^{177} \mathrm{Lu} \mathrm{e}{ }^{90} \mathrm{Y}$, para tratamento desses tumores (Thomas et al., no prelo).

\subsubsection{Considerações para o desenvolvimento de moléculas para terapia radioisotópica}

O desenvolvimento de um radiofármaco efetivo para terapia radioisotópica envolve, além das considerações geométricas relacionadas ao tumor, a correta seleção de seus dois componentes: o radioisótopo e a molécula carreadora. Denomina-se molécula carreadora o agente que será utilizado para direcionar o radioisótopo para o tumor e assim aumentar a probabilidade da radiação ser depositada seletivamente no interior das células tumorais. É necessário, portanto, unir um agente com comportamento biológico efetivo para a classe de tumor que se deseja tratar a um radioisótopo com propriedades físicas adequadas para utilização in vivo, cujas propriedades químicas permitam sua ligação à molécula (Kassis e Adelstein, 2003).

\subsubsection{Considerações Geométricas}

A idéia de otimizar o alcance da partícula radioativa para um tipo particular de tumor é inviável, uma vez que implicaria no conhecimento detalhado de suas dimensões. E na necessidade de diferentes radioisótopos para serem aplicados a diferentes pacientes, o que tornaria a terapia impraticável. No entanto, é possível fazer algumas generalizações na determinação do radioisótopo mais adequado para o tratamento.

Para pequenos tumores, em condições em que o radioisótopo é depositado uniformemente, a dose de radiação recebida pelas células depende de suas posições na lesão. O decaimento radioativo deve provocar maior efeito no núcleo da célula, organela responsável pela morte mediada por radiação. Nesse caso diferentes radioisótopos podem ser utilizados, sendo os emissores de partículas $\beta^{-}$de baixa energia os mais indicados por acarretarem menor dose de radiação aos tecidos adjacentes ao tumor. Em contrapartida, emissores $\beta^{-}$de alta energia ou emissores $\alpha$ podem ser aplicados para o tratamento de tumores de grandes dimensões por depositarem maior parte de sua energia nas células tumorais (Zalutsky, 2003). 


\subsubsection{Seleção do radioisótopo}

Um grande número de fatores influencia na escolha do radioisótopo para uma aplicação terapêutica particular. No caso do tratamento de neoplasias, o primeiro fator a ser considerado é se a forma de decaimento e a energia da partícula emitida condizem com as dimensões e a geometria do tumor. Um radioisótopo ideal para tratar tumores sólidos de grandes dimensões será diferente daquele aplicado para eliminar pequenos sítios metastáticos, compostos apenas de algumas centenas de células. Além desses fatores, a meia-vida, o método de produção, a química e o comportamento biológico do radioisótopo também devem ser considerados (Zalutsky, 2003). Na TAB. 1 são mostradas as características físicas de radioisótopos para terapia.

TABELA 1 - Características físicas de radioisótopos aplicados em terapia.

\begin{tabular}{|c|c|c|c|}
\hline Modo de decaimento & Partículas & Energia & Alcance \\
\hline$\beta^{-}$ & Elétrons & $\begin{array}{c}\text { Média a alta } \\
(0,5-2,3 \mathrm{MeV})\end{array}$ & $1-12 \mathrm{~mm}$ \\
\hline$\alpha$ & Núcleos de hélio & $\begin{array}{c}\text { Alta } \\
\text { (alguns MeV) }\end{array}$ & $50-100 \mu \mathrm{m}$ \\
\hline $\mathrm{CE} / \mathrm{CI}^{*}$ & $\begin{array}{c}\text { Elétrons Auger / } \\
\text { Életrons de } \\
\text { conversão }\end{array}$ & $\begin{array}{c}\text { Baixa } \\
(\mathrm{eV}-\mathrm{keV})\end{array}$ & Alguns nm \\
\hline
\end{tabular}

Fonte: Kassis e Adelstein, 2003. $\mathrm{CE}=$ captura eletrônica, $\mathrm{CI}=$ conversão interna.

Atualmente, os isótopos utilizados na clínica para terapia radioisotópica são exclusivamente emissores de partículas $\beta^{-}$. Ainda que, na teoria, tanto radioisótopos emissores de partículas $\alpha$ ou $\beta^{-}$possam ser utilizados, apenas esses últimos vêm sendo efetivamente empregados. Os elétrons emitidos de um núcleo em decaimento $\beta^{-}$(um elétron / decaimento) apresentam espectro de energia e alcance variados. Os dados contidos na TAB. 2 mostram o perfil de alguns emissores de partículas $\beta^{-}$(Kassis e Adelstein, 2003). 
TABELA 2 - Características físicas de alguns emissores de partículas $\beta^{-}$.

\begin{tabular}{cccccc}
\hline Radioisótopo & Meia-vida & $\begin{array}{c}\text { Energia } \\
\text { média do } \beta^{-} \\
(\mathbf{k e V})\end{array}$ & $\begin{array}{c}\text { Alcance } \\
\text { médio do } \beta^{-} \\
(\mathbf{m m})\end{array}$ & $\begin{array}{c}\text { Energia } \\
\text { máxima do } \\
\boldsymbol{\beta}^{-}(\mathbf{k e V})\end{array}$ & $\begin{array}{c}\text { Alcance } \\
\text { máximo do } \\
\boldsymbol{\beta}^{-} \text {(mm) }\end{array}$ \\
\hline${ }^{32} \mathrm{P}$ & $14,3 \mathrm{~d}$ & 695 & 2,8 & 1710 & 8,2 \\
${ }^{177} \mathrm{Lu}$ & $6,7 \mathrm{~d}$ & 133 & 0,23 & 497 & 1,8 \\
${ }^{131} \mathrm{I}$ & $8,0 \mathrm{~d}$ & 182 & 0,39 & 610 & 2,3 \\
${ }^{153} \mathrm{Sm}$ & $46,8 \mathrm{~h}$ & 224 & 0,54 & 805 & 3,3 \\
${ }^{188} \mathrm{Re}$ & $17,0 \mathrm{~h}$ & 764 & 3.1 & 2120 & 10.4 \\
${ }^{90} \mathrm{Y}$ & $64,1 \mathrm{~h}$ & 935 & 4,0 & 2284 & 11,3 \\
\hline
\end{tabular}

Fonte: Kassis e Adelstein, 2003

Ao interagir com a matéria, as partículas $\beta^{-}$podem sofrer alteração de sua rota, e consequente redução de sua energia cinética, a qual pode chegar a zero. Uma vez que a transferência linear de energia (LET) nessa interação é relativamente baixa $(0,2 \mathrm{keV} / \mu \mathrm{m})$, pode-se afirmar que essas partículas são pouco eficientes em lesar o DNA das células-alvo. Portanto, para serem utilizados como agentes terapêuticos, os emissores $\beta^{-}$devem estar presentes em altas concentrações no tecido tumoral, transferindo milhares de elétrons a cada célula cancerosa (Kassis e Adelstein, 2003). Essa especificidade é assegurada pela molécula carreadora.

\section{A) Lutécio-177 ( $\left.{ }^{177} \mathrm{Lu}\right)$}

O lutécio ocorre na natureza como óxido de lutécio-175. O lutécio-177 é o isótopo radioativo produzido em reatores de alto fluxo através do bombardeamento de um alvo enriquecido em óxido de lutécio-176 (71\%), comercialmente disponível. A produção de lutécio-177 livre de carreador também é possível e é recomendável para aplicações médicas que exijam alta atividade específica da molécula a ser radiomarcada. Nesse caso o radioisótopo é produzido a partir da reação ${ }^{176} \mathrm{Yb}(\mathrm{n}, \gamma){ }^{177} \mathrm{Yb}\left(\mathrm{T}_{1 / 2} 1,9 \mathrm{~h}\right) . \mathrm{O}{ }^{177} \mathrm{Yb}$ decai por emissão de radiação $\beta^{-}$para ${ }^{177} \mathrm{Lu}$. A separação desses dois radioisótopos, por sua vez, é feita em duas etapas (Zalutsky, 2003). 
A aplicação do lutécio-177 na produção de radiofármacos para terapia radioisotópica é recente e vem se intensificando nos últimos anos. Esse crescente uso atribui-se às propriedades físicas e químicas desse radioisótopo. A meia-vida do ${ }^{177} \mathrm{Lu}$ é 6,65 dias, significativamente maior do que a de outros radiolantanídeos como ${ }^{153} \mathrm{Sm} \mathrm{e}^{90} \mathrm{Y}$, o que permite sua utilização em processos mais complexos de radiomarcação, os quais demandam maior tempo e trabalho. Além disso, o lutécio-177 emite radiação $\beta^{-}$de 497 $\mathrm{keV}$ de energia máxima e $230 \mu \mathrm{m}$ de alcance médio, ideal para o tratamento de micrometástases, como as geradas pelos tumores de próstata hormônio-refratários. A emissão concomitante de radiação $\gamma$ de $208 \mathrm{keV}$ de energia confere ao lutécio aplicação diagnóstica na obtenção de imagem cintilográfica. Finalmente, é relativamente simples conjugar esse radiolantanídeo a inúmeros compostos biologicamente ativos, desde que esses sejam ligados a um agente quelante (Mikolajczak et al., 2003).

O lutécio-177 apresenta características químicas similares à de outros lantanídeos. Ainda que estados de oxidação +2 ou +4 sejam conhecidos para lantanídeos, o estado de oxidação +3 é o mais comum e relevante para aplicação em radiofarmácia e medicina nuclear. Como ácidos de Lewis fortes, as reações químicas envolvendo cátions de lantanídeos +3 são dominadas por química de coordenação e interação com bases de Lewis fortes, doadoras de elétrons, como átomos de nitrogênio e oxigênio. A ligação com o lutécio-177 é iônica e necessita de quelantes multidentados, aniônicos e macrocíclicos, a fim de garantir a estabilidade do complexo molécula carreadora-radiolantanídeo. $\mathrm{O}{ }^{177} \mathrm{Lu}$ mimetiza o cálcio in vivo e apresenta alta afinidade pelo tecido ósseo. Na ausência de ligantes que satisfaçam seu número de coordenação, esse radiolantanídeo forma um radiocolóide em pHs maiores que $4-{ }^{177} \mathrm{Lu}(\mathrm{OH})_{3}$ - que se acumula no fígado. A química do lutécio-177 envolve sua dissolução e manutenção em ácido clorídrico. Em pHs maiores que 4 seus hidróxidos se precipitam. Para prevenir essa reação, tampão citrato ou acetato de amônio são utilizados em pHs que variam entre 4,5 e 7. Finalmente, a formação do radiofármaco pode requerer aquecimento, dependendo do agente quelante utilizado (Jurisson et al., 2008).

O potencial terapêutico do ${ }^{177} \mathrm{Lu}$ vem sendo avaliado em conjunto com uma série de substâncias carreadoras. Um estudo comparativo entre o peptídeo [DOTA ${ }^{0}, \mathrm{Tyr}^{3}$ ] octreotato marcado com ${ }^{111} \mathrm{In},{ }^{90} \mathrm{Y}$ ou ${ }^{177} \mathrm{Lu}$ mostrou que a captação do peptídeo radiomarcado com lutécio-177 por tumores pancreáticos foi mais alta do que quando marcado pelos outros dois radioisótopos (Breeman et al., 2003). Frente aos resultados 
encorajadores o $\left[{ }^{177} \mathrm{Lu}\right.$-DOTA $\left.{ }^{0}, \mathrm{Tyr}^{3}\right]$ octreotato foi também avaliado em estudos clínicos e os resultados foram promissores (Kwekkeboom et al., 2003). Atualmente, já existem derivados da somatostatina radiomarcados com lutécio-177 disponíveis comercialmente em todo o mundo, dentre eles o Octreotídeo- ${ }^{177} \mathrm{Lu}$, utilizado no Brasil para tratamento de tumores neuroendócrinos.

\subsubsection{Seleção da molécula carreadora}

A molécula carreadora pode ser uma partícula, um anticorpo ou um peptídeo.

\section{A) Partículas de vidro ou hidroxiapatita}

Muitos dos primeiros trabalhos envolvendo terapia radioisotópica utilizavam partículas radiomarcadas. Atualmente esses agentes ainda são objeto de estudo de vários trabalhos, sendo normalmente empregados em administração local quando o tumor ou outra patologia está localizado em um compartimento isolado. O objetivo nesse caso é garantir uma distribuição uniforme do radiofármaco na cavidade e minimizar a dose de radiação ao restante do corpo. Além da estabilidade, uma característica importante das partículas é o seu tamanho, o qual determina não apenas a homogeneidade da dose depositada, mas também a sua permanência no local destinado.

A aplicação mais frequente das partículas está relacionada à artrite reumatóide. Nesse processo, a partícula radiomarcada é injetada na articulação e destrói seletivamente o tecido inflamado, em uma alternativa de menor custo e tempo de hospitalização que o tratamento cirúrgico. A técnica é conhecida como radiosinovectomia (Kassis e Adelstein, 2003).

\section{B) Anticorpos}

Nas últimas décadas observou-se uma rápida evolução no desenvolvimento de radiofármacos de origem protéica, principalmente devido às limitações na aplicação de partículas. A marcação de anticorpos monoclonais e sua utilização como ferramenta no diagnóstico e terapia de tumores surgiu como uma alternativa promissora. Eles apresentam alta afinidade e especificidade pelo tecido tumoral e promovem um excelente contraste entre tecido marcado e radiação de fundo na imagem refletida, além de reduzir a dosimetria ao paciente na terapia. No entanto, o alto peso molecular dos anticorpos compromete sua utilização, uma vez que implicam em longa meia-vida plasmática e lenta 
difusão através dos tecidos e do tumor. Além disso, essas macromoléculas são primariamente metabolizadas pelo fígado e excretadas para o trato biliar e o intestino, aumentando significativamente a dosimetria e a radiação de fundo nesses órgãos (Weiner e Thakur, 2001).

Uma propriedade desejável à molécula carreadora é a rápida remoção da circulação sanguínea e excreção principalmente renal. O acúmulo da radiação nos rins é um fato indesejável e o radiofármaco deve ser prontamente eliminado através da urina. Para tanto é necessário reduzir o tamanho da molécula carreadora, o que no caso dos anticorpos significaria clivá-los em seus fragmentos. Todavia, essa redução de tamanho também provoca reduções na afinidade e especificidade da molécula (Knight, 2003). Nesse contexto surgiu a possibilidade de utilizar peptídeos como moléculas carreadoras.

\section{C) Peptídeos}

Uma alternativa aos anticorpos é a utilização de pequenos peptídeos, compostos de 50 aminoácidos ou menos. Há três diferenças entre os peptídeos e as proteínas que representam implicações fundamentais na terapia radioisotópica. Por apresentarem menor tamanho, essas moléculas são clareadas do sangue e dos tecidos sadios mais rapidamente. Outra consequência de seu baixo peso molecular é a penetração mais rápida e homogênea no tumor. Além disso, peptídeos são menos imunogênicos que as proteínas, tornando possível um esquema terapêutico que envolva a administração de múltiplas doses. Finalmente, ainda que o desenvolvimento de novas tecnologias tenha reduzido o custo de produção de proteínas, a síntese de peptídeos ainda é mais conveniente (Zalutsky, 2003).

O uso de peptídeos não apresenta apenas vantagens. A maioria dos peptídeos em estudo, para aplicação em terapia radioisotópica, são peptídeos regulatórios e ainda que seus receptores sejam encontrados em maior densidade nas células tumorais, eles são também encontrados em tecidos normais, principalmente no trato gastrointestinal. Portanto, esses peptídeos regulatórios causam efeitos fisiológicos em baixas concentrações, o que torna importante a adoção de uma metodologia de marcação que assegure alta atividade específica do composto radiomarcado. Sua baixa estabilidade in vivo, demonstra a necessidade de modificações estruturais que aumentem a estabilidade. Além disso, como consequência de sua rápida eliminação renal, esses agentes podem provocar radiotoxicidade aos rins, o que limitaria sua utilização. Uma possível solução para esse inconveniente é a coadministração de aminoácidos básicos, os quais inibem a reabsorção 
tubular dos peptídeos que sofreram filtração glomerular (Zalutsky, 2003).

Diversos peptídeos regulatórios apresentam alta afinidade por células tumorais, geralmente por superexpressarem seus receptores, permitindo uma melhor visualização do tumor no reflexo da imagem cintilográfica e a aquisição em um menor intervalo de tempo após a administração, em razão do rápido clareamento sanguíneo dessas moléculas. Esse mesmo peptídeo, quando radiomarcado com um emissor beta e gama, por exemplo, atuará também como agente terapêutico do tumor primário e de possíveis sítios metastáticos. Dentre promissores peptídeos estão o octreotídeo, o octreotato, o peptídeo intestinal vasoativo (VIP), a substância P e a bombesina (Knight, 2003).

\subsection{Bombesina}

A bombesina $(\mathrm{BBN})$ é um neuropeptídeo de 14 aminoácidos análogo dos peptídeos humanos liberador de gastrina (GRP) e neuromedina B (NMB) e foi originalmente isolada da pele do anfíbio Bombina bombina em 1970 (Anastasi et al., 1970). A estrutura da bombesina é mostrada na FIG. 3.

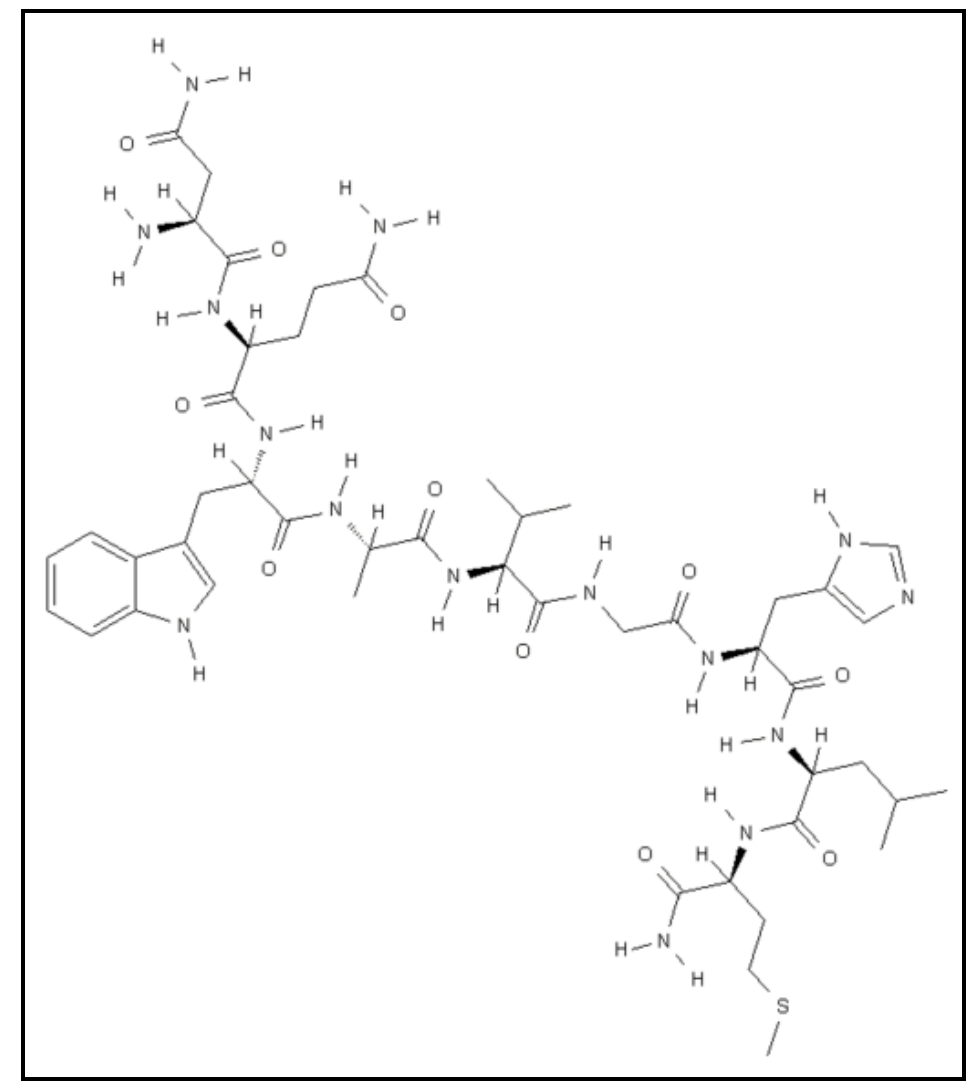

FIGURA 3 - Estrutura da bombesina (Estrutura do peptídeo bombesina, 2009). 
A bombesina exerce seus efeitos nas células alvo através da ligação a receptores acoplados à proteína $\mathrm{G}$, com sete domínios transmembrana, e ativa a fosfolipase C, aumentando a concentração intracelular de inositol fosfato, diacilglicerol e cálcio. Outros mediadores intracelulares ativados pela ligação da BBN aos seus receptores são a proteína quinase ativadora de mitose, a proteína quinase de adesão focal, o fosfatidilinositol 3-quinase e, em alguns casos, o AMP cíclico. A ativação desses receptores desencadeia uma série de funções fisiológicas, além da estimulação da secreção de ácido gástrico. Além de estimular a liberação de vários hormônios, dentre eles a gastrina e a somatostatina, estimula a secreção exócrina pancreática e a contração do músculo liso no estômago e do intestino delgado. A BBN apresenta também efeito proliferativo e protetor contra danos sobre a mucosa do pâncreas e do trato gastrointestinal. Seus efeitos no sistema nervoso central são termorregulação, inibição do hormônio estimulador da função tireoidiana (TSH) e manutenção do ciclo circadiano, além de alterações comportamentais, inibição do apetite e melhoras na memória e no aprendizado em modelos animais (La Bella et al., 2002; Patel et al., 2006).

Atualmente, existem três tipos de receptores para bombesina descritos em mamíferos, sendo eles o receptor para NMB (NMBr), o receptor para GRP (GRPr) e o receptor órfão $\mathrm{BB}_{3}$, assim denominado por se desconhecer seu ligante endógeno. O quarto receptor, $\mathrm{BB}_{4}$, ainda não foi descrito em mamíferos, apenas em anfíbios (Thomas et al., no prelo). A homologia entre os grupamentos $\mathrm{C}$-terminal da $\mathrm{BBN}$ e dos peptídeos endógenos NMB e GRP é mostrada na FIG. 4 e explica sua ligação aos receptores desses dois peptídeos.

\begin{tabular}{|cl|}
\hline Bombesina & Gly-Asn-Gln-Trp-Ala-Val-Gly-His-Leu-Met-CONH \\
GRP & Gly-Asn-His-Trp-Ala-Val-Gly-His-Leu-Met-CONH \\
NMB & Gly-Asn-Leu-Trp-Ala-Val-Gly-His-Leu-Met-CONH \\
\hline
\end{tabular}

FIGURA 4 - Sequência dos grupamentos C-terminal da bombesina, do peptídeo liberador de gastrina e da neuromedina B (Patel et al., 2006).

$\mathrm{O}$ interesse em derivados da bombesina radiomarcados para diagnóstico e/ou terapia de tumores tem crescido consideravelmente a partir da observação de que os GRPr são superexpressos em alguns tipos de células tumorais, dentre elas as do câncer de próstata, cólon, mama e pulmão, além de glioblastomas e neuroblastomas (Reubi, 2003). Portanto, derivados da bombesina podem ser utilizados para carrear um isótopo radioativo 
até as células desses tumores, permitindo sua detecção e/ou tratamento, como já considerado anteriormente em alguns trabalhos de revisão (Varvarigou et al., 2004; Maina et al., 2006; Patel et al., 2006).

A expressão de GRPr em células de adenocarcinoma de próstata humano foi estudada por autorradiografia, utilizando-se $\left[{ }^{125} \mathrm{I}-\mathrm{Tyr}^{4}\right] \mathrm{BBN}$ como radioligante. A próstata normal ou hiperplásica se mostrou negativa para GRPr, enquanto esses receptores são encontrados em alta densidade em carcinomas, em lesões intraepiteliais proliferativas e na fase inicial da transformação neoplásica. A ativação desses receptores regula a morfologia celular, a diferenciação e a proliferação, assim como a expressão de genes que ativam a angiogênese. Provavelmente esses receptores são marcadores dos eventos moleculares que precedem a carcinogênese e ainda constituem útil ferramenta na diferenciação entre hiperplasia e neoplasia prostática. A presença de GRPr é de importante significado biológico e forma a base molecular para o diagnóstico e tratamento dos tumores prostáticos por cintilografia e terapia radioisotópica, respectivamente (Markwalder e Reubi, 1999). Além da detecção de tumor prostático, a possibilidade de identificação da fase inicial da transformação neoplásica através dos GRPr é extremamente atrativa porque ela provavelmente representaria detecção antecipada do tumor e, por consequência, melhoria no prognóstico dos pacientes.

Um estudo pré-clínico em ratos normais com a litorina, um análogo natural da bombesina, radiomarcada com tecnécio-99m foi publicado recentemente. Os resultados dos experimentos de biodistribuição mostraram significativa captação em tecidos sadios que comumente expressam receptores GRP, especialmente no pâncreas. Os estudos de competição in vivo sugeriram especificidade na ligação da litorina aos receptores presentes nesse órgão. Entretanto, o acúmulo no pâncreas sugere que a molécula da litorina e, por consequência, da bombesina não modificada é inadequada para a aplicação clínica (Durkan et al., 2007). Resultados semelhantes foram obtidos para o derivado MP2346, substituído em dois aminoácidos (Pro ${ }^{1}-$ Try $\left.^{4}-\mathrm{BBN}\right)$, complexado ao quelante DOTA e radiomarcado com ${ }^{64} \mathrm{Cu}$ e ${ }^{86} \mathrm{Y}$ (FIG. 5). Os estudos de biodistribuição em camundongos Nude com tumor de próstata humano mostraram importante captação tumoral, mas também alto acúmulo pancreático (Biddlecombe et al., 2007). Esses resultados foram confirmados pelos estudos de imagem e mais uma vez indicaram a necessidade de maiores modificações na estrutura da bombesina a fim de aumentar sua seletividade pelas células tumorais. 


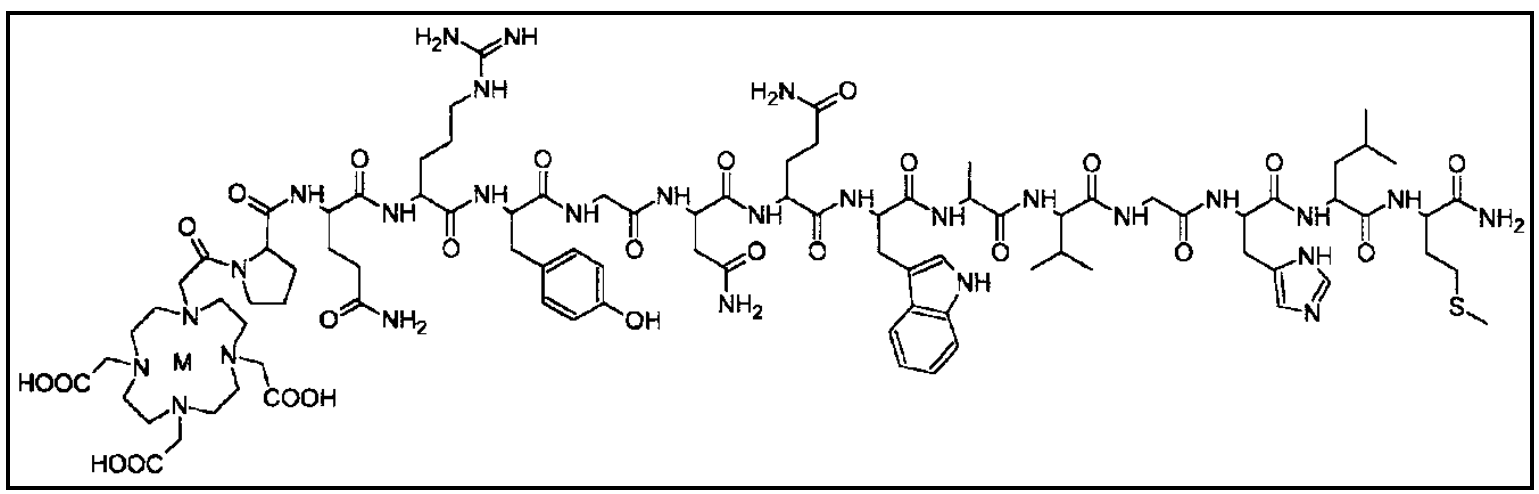

FIGURA 5 - Estrutura do derivado MP2346, em que M é o radiometal (Biddlecombe et al., 2007).

Alterações moleculares na estrutura da bombesina vêm sendo promovidas a fim de melhorar sua afinidade pelos receptores e especificidade pelas células tumorais. Essas modificações ocorrem principalmente na porção N-terminal do peptídeo, uma vez que a porção C-terminal, que compreende a sequência do aminoácido sete (Gln) ao aminoácido 14 (Met), é responsável pela interação com os receptores e atividade biológica do peptídeo (Moody et al., 1982). A porção modificada é comumente denominada espaçador e as moléculas produzidas são derivados ou análogos da bombesina.

Derivados da bombesina não radiomarcados foram propostos para o tratamento do câncer. Nesse caso os análogos utilizados são antagonistas da bombesina, uma vez que os agonistas são estimuladores da proliferação celular, não sendo adequados para tratamento antitumoral ( $\mathrm{Zhu}$ et al., 2007). No contexto dos antagonistas da bombesina, alguns derivados com espaçadores orgânicos não peptídicos foram reportados (Peptide Technologies Corporation, 1997; Merrell Pharmaceuticals Inc., 1998; Dabur Research Foundation, 2006). Apesar de apresentarem atividade citotóxica contra células de diferentes linhagens tumorais, a aplicação dessas moléculas em estudos clínicos é questionável. A administração dos derivados em concentrações terapêuticas, as quais são relativamente altas, pode acarretar sérios efeitos adversos ao paciente devido ao bloqueio do GRPr em tecidos sadios e, consequentemente, bloqueio das respostas fisiológicas desencadeadas pela sua ativação. Os derivados obtidos a partir da inserção de espaçadores orgânicos não peptídicos apresentam um caráter lipofílico maior em relação à bombesina nativa, o que dificulta a excreção renal e favorece o acúmulo da molécula no organismo, especialmente no fígado.

Os inconvenientes associados à aplicação de antagonistas da bombesina no tratamento de tumores despertaram o interesse em utilizar seus derivados como carreadores 
de um isótopo radioativo às células tumorais. Dependendo das características físicas do radioisótopo acoplado, os derivados podem ser aplicados para terapia antitumoral e/ou para diagnóstico por tomografia por emissão de fóton único (SPECT) ou tomografia por emissão de pósitron (PET). Dentre as vantagens mostradas pelos derivados da bombesina como carreadores de um isótopo radioativo está à possibilidade de utilização não só de antagonistas, mas também de agonistas, considerando-se a massa do derivado da bombesina no radiofármaco administrado ao paciente em relação às concentrações dos antagonistas não radiomarcados utilizados em terapia.

Derivados da bombesina constituídos pelo quelante 1,4,7,10tetraazaciclododecano-1,4,7,10-ácido tetra-acético (DOTA) e diferentes espaçadores orgânicos de caráter aminoacídico (aminoácido $\beta$-Ala) e não aminoacídico (5-Ava, 8-Aoc e 11-Aun) foram marcados com radioisótopos para diagnóstico e terapia. A análise da biodistribuição em camundongos sadios e injetados com células tumorais humanas de próstata (PC-3) e mama (MDA-MB-231) mostrou que o comportamento biológico dos derivados é diretamente influenciado pelo tipo de tumor, pelo radioisótopo e também pela natureza do grupamento espaçador. Nesse caso, o análogo com grupamento espaçador aminoacídico, representado pelo $\beta$-Ala, apresentou vantagens em relação aos demais quanto à captação abdominal, significativamente menor no pâncreas e no intestino. $\mathrm{O}$ aumento no tamanho da cadeia carbônica do espaçador favorece o acúmulo abdominal. Portanto, a natureza (orgânica ou inorgânica) e o tamanho da cadeia carbônica dos espaçadores dos derivados da bombesina influenciam diretamente em seu comportamento biológico (Hu et al., 2002; Hoffman et al., 2003; Johnson et al., 2006). Os mesmos derivados radiomarcados com ${ }^{99 \mathrm{~m}} \mathrm{Tc}$ e ligados ao agente quelante $\mathrm{N}_{3} \mathrm{~S}$ (FIG. 6) foram incluídos em um estudo de Smith e colaboradores (2003), obtendo-se resultados semelhantes. 


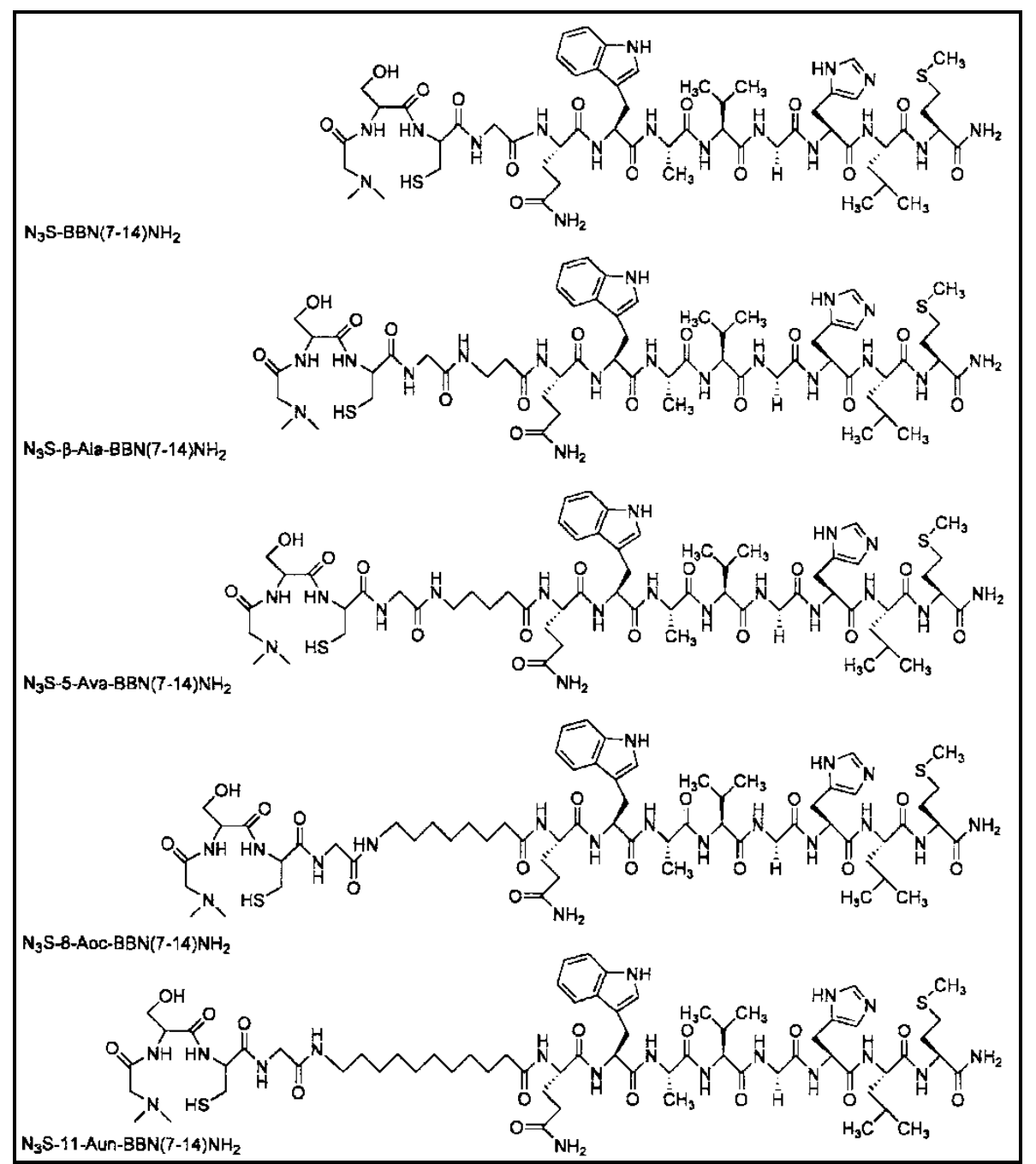

FIGURA 6 - Derivados da bombesina com diferentes tipos de espaçadores e ligados ao agente quelante $\mathrm{N}_{3} \mathrm{~S}$ (Smith et al., 2003).

A influência da extensão da cadeia carbônica do espaçador sobre o comportamento de derivados da bombesina ligados ao DOTA e radiomarcados $\operatorname{com}{ }^{64} \mathrm{Cu}$ foi estudado com espaçadores orgânicos não peptídicos de 4, 5, 6, 8 e 12 carbonos (FIG. 7). O aumento na cadeia carbônica reduziu a ligação dos derivados às células de tumor de mama (T47-D) in vitro, mas aumentou a sua internalização. Nos estudos in vivo, utilizando-se modelo animal de tumor de mama, demonstrou-se que o aumento na cadeia carbônica aumenta a captação hepática e reduz a captação tumoral, exceto quando se aumenta o número de carbonos de 8 para 12 , em que não se observa incremento na captação tumoral. Com base nos resultados, os autores sugerem que o caminho para redução da captação em tecidos sadios não se baseia apenas na diminuição no tamanho dos espaçadores, mas também na modificação de suas estruturas (Parry et al., 2007a). 


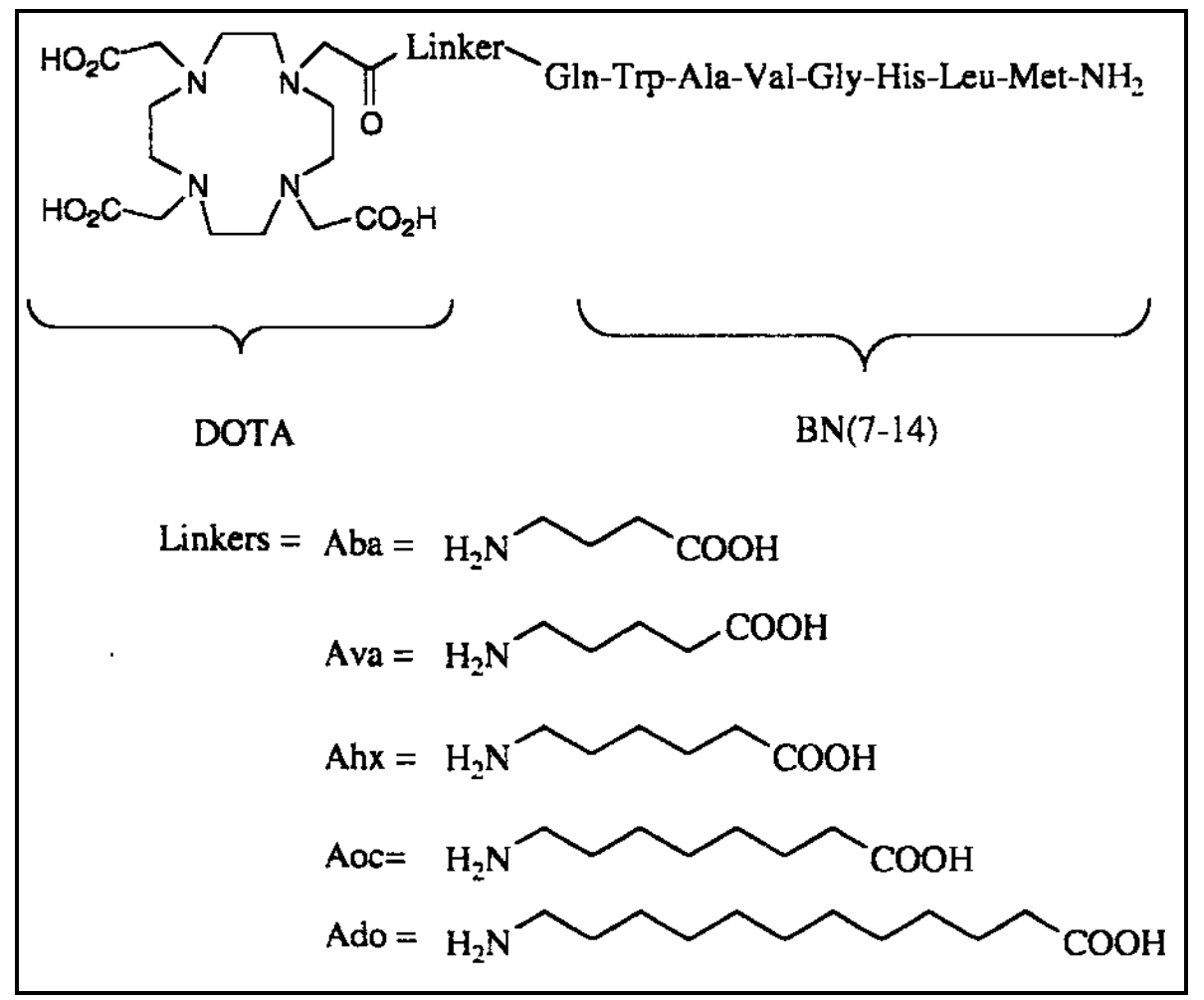

FIGURA 7 - Espaçadores orgânicos de derivados da bombesina complexados ao DOTA e estudados por Parry e colaboradores (2007a).

O grupamento quelante para marcação com os diferentes radioisótopos também influencia na biodistribuição dos derivados da bombesina, especialmente na captação tumoral, eliminação renal e acúmulo no pâncreas e no intestino. Diferenças entre derivados ligados ao DOTA e ao ácido dietilenotriaminopentacético (DTPA) e radiomarcados com ${ }^{111}$ In foram reportadas, especialmente na captação por tecidos que geralmente expressam GRPr. Os derivados ligados ao DOTA apresentaram maior afinidade por esses tecidos (Breeman et al., 2002). Estudos publicados recentemente com o mesmo derivado da bombesina - $\beta$-Ala-BBN(7-14) - ligado aos quelantes DTMA (ácido 2-N,N'-bis-tercbutoxicarbonil-dietilenotriaminoacético) (Lane et al., 2008) e HYNIC (ácido 6hidrazinopiridina-3-carboxílico) (Faintuch et al., 2008) e radiomarcado com ${ }^{99 \mathrm{~m}} \mathrm{Tc}$ mostraram que o derivado ligado ao DTMA apresenta menor captação por células de tumor de próstata e eliminação renal e maior captação pancreática e intestinal do que o derivado ligado ao HYNIC. Estes resultados sugerem que há uma relação inversa entre eliminação renal e acúmulo abdominal e ainda indicam que não há relação direta entre captação tumoral e acúmulo nos tecidos que comumente expressam GRPr.

Lantry e colaboradores (2006) descreveram a síntese e a caracterização do derivado agonista da bombesina AMBA radiomarcado com ${ }^{177} \mathrm{Lu}$ (FIG. 8), um isótopo 
com aplicações em diagnóstico por SPECT e terapia, especialmente de pequenos tumores e micrometástases. $\mathrm{O}$ espaçador desse análogo é misto, constituído de uma cadeia carbônica que reúne aminoácidos e grupamentos orgânicos não peptídicos. Esse derivado apresentou boas propriedades de ligação e internalização pelos receptores GRP nos estudos com células PC-3 de adenocarcinoma de próstata humano in vitro e alta captação tumoral nos estudos in vivo. No entanto, também apresentou alta captação pelo pâncreas e demais órgãos do sistema gastrointestinal. Esse resultado conduziu ao estudo de Waser e colaboradores (2007) e, mais recentemente, de Thomas e colaboradores (no prelo), que avaliaram a ligação do $\mathrm{AMBA}-{ }^{177} \mathrm{Lu}$ a receptores GRP e NMB em diferentes cortes de tecidos e tumores humanos in vitro. As análises evidenciaram a ausência de receptores GRP no pâncreas humano, ao contrário do observado em camundongos, e a presença desses receptores em carcinomas de próstata, mama, rins e cólon e também em células sadias do músculo liso e plexo mesentérico do trato gastrointestinal. Esses resultados mostraram a necessidade de se obter um análogo mais seletivo, uma vez que a irradiação das células do trato gastrointestinal, principalmente das células intestinais, conhecidamente radiossensíveis, pode acarretar efeitos adversos irreversíveis ao paciente. O AMBA também foi inserido recentemente em um estudo comparativo envolvendo derivados da bombesina com diferentes espaçadores e radiomarcados com ${ }^{111} \mathrm{In}$. Os resultados obtidos foram semelhantes aos descritos para os derivados do estudo marcados com outros radioisótopos, ou seja, importante captação tumoral, mas também alto acúmulo abdominal (Garrison et al., 2008).

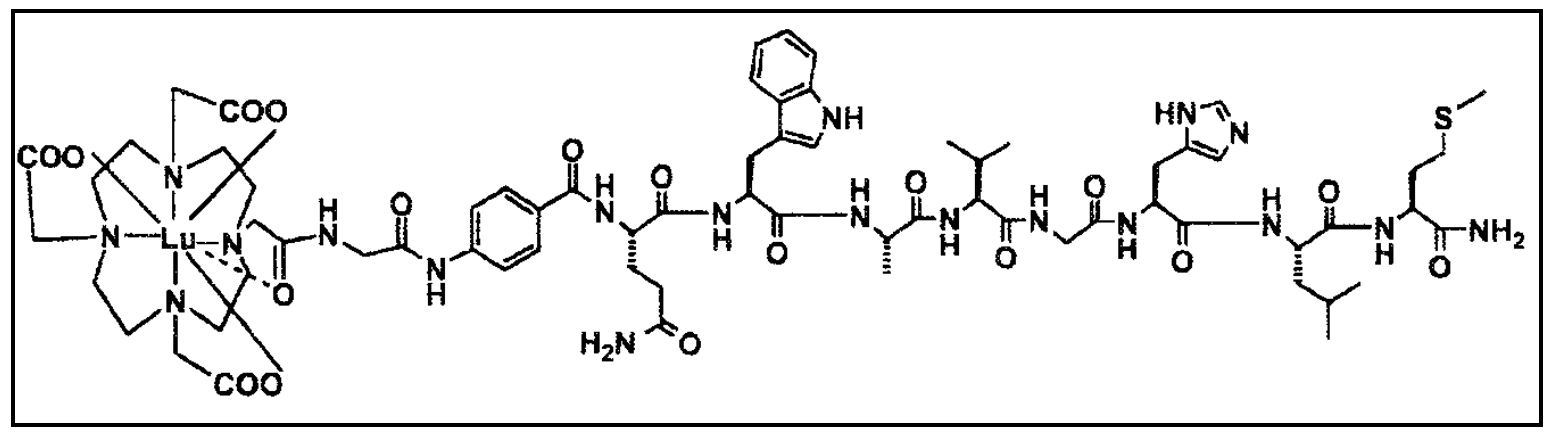

FIGURA 8 - Estrutura do AMBA- ${ }^{177} \mathrm{Lu}$ (Chen et al., 2008).

Diferentes derivados agonistas da bombesina ligados ao DOTA, compostos por espaçadores de aminoácidos não modificados e a sequência da bombesina do aminoácido sete ao aminoácido 14 (FIG. 9), foram descritos recentemente para aplicação no diagnóstico por PET (Parry et al., 2007b). A análise da biodistribuição dos derivados 
radiomarcados com ${ }^{64} \mathrm{Cu}$ em camundongos $\mathrm{Nude}$ implantados com células PC-3 mostrou importante captação tumoral, mas também acúmulo abdominal, especialmente no pâncreas e intestino. Apesar de esse acúmulo ser menor em relação aos demais derivados com espaçadores de outra natureza, ele ainda representa uma barreira à sua aplicação clínica.

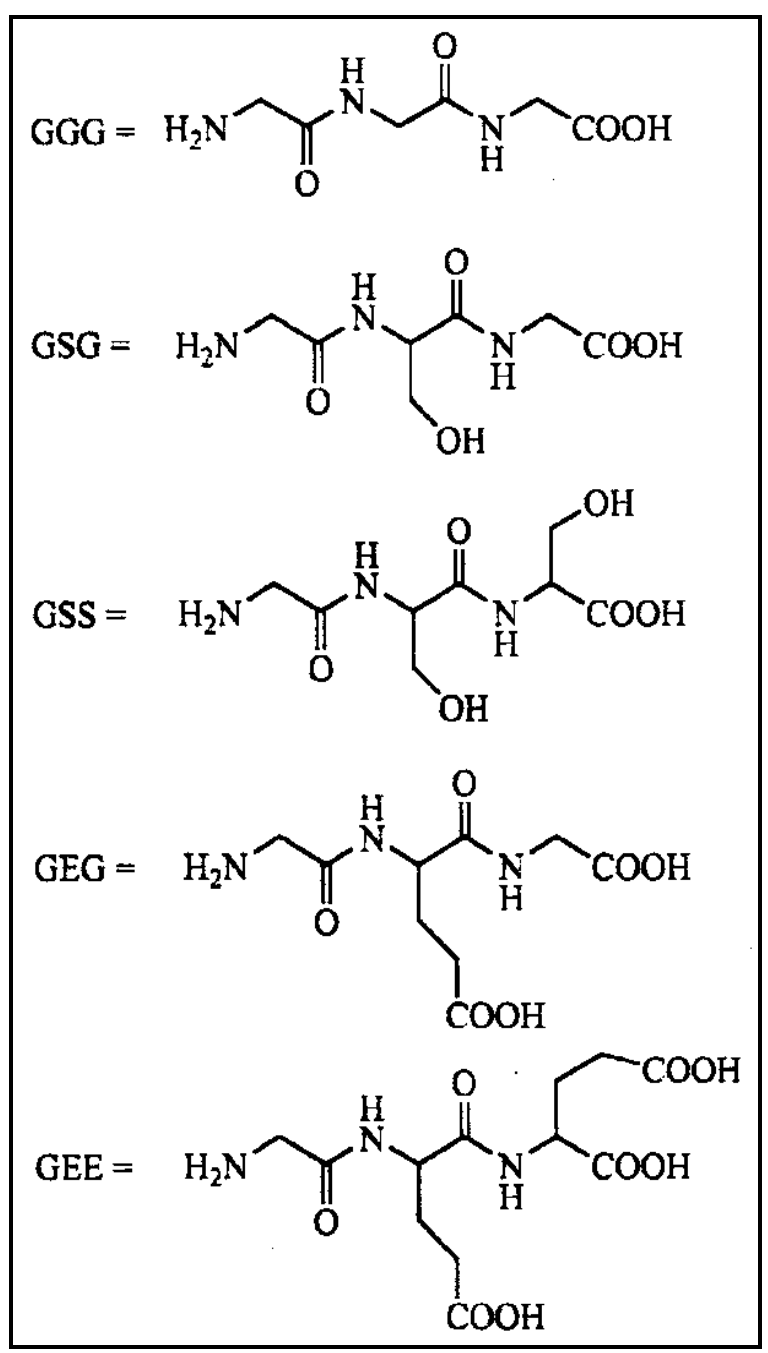

FIGURA 9 - Espaçadores aminoacídicos de derivados da bombesina estudados por Parry e colaboradores (2007b).

Até o presente, foram realizados dois estudos clínicos com derivados da bombesina radiomarcados. O primeiro deles, com o derivado da bombesina RP527 radiomarcado com tecnécio-99m, envolveu homens e mulheres sadios (Van de Wiele et al., 2001). Apesar de nenhum efeito adverso, alteração das funções vitais ou dos parâmetros bioquímicos dos pacientes terem sido reportados durante todos os experimentos, observouse, pelas análises das imagens, alta captação hepática e intestinal, demonstrando a existência de mecanismo de excreção por essa rota. Essa alta captação, detectada até 24 
horas após a administração intravenosa do derivado, resultou em uma alta dose de radiação absorvida pelo fígado e intestino e provavelmente impossibilitou os estudos envolvendo pacientes com tumor. $\mathrm{O}$ derivado também foi significativamente captado pela mama das pacientes normais, não sendo adequado, portanto, para aplicação no diagnóstico de câncer de mama. Apesar desses inconvenientes, o estudo concluiu que, do ponto de vista de dosimetria, o uso clínico do RP527- $-{ }^{99 \mathrm{~m}} \mathrm{Tc}$ é favorável considerando-se as doses administradas para aplicação em SPECT. Mais recentemente, foi descrito o segundo estudo clínico, o qual envolveu o derivado EDDA/HYNIC-[ $\left.\mathrm{Lys}^{3}\right]$-bombesina radiomarcado com tecnécio-99m em mulheres sadias e portadoras de câncer de mama (Santos-Cuevas et al., 2008). Os resultados mostraram que nenhuma das 11 mulheres estudadas apresentou efeitos adversos após a administração do radiofármaco e também acúmulo abdominal reduzido em relação ao RP527- ${ }^{99 m}$ Tc. Porém, não houve diferença significativa entre a captação mamária nas mulheres sadias e portadoras do câncer de mama, indicando que esses derivados não são adequados para imagem tumoral.

Apesar do grande número de derivados agonistas e antagonistas da bombesina desenvolvidos e radiomarcados, um radioligante com características adequadas para aplicação in vivo, ou seja, que apresenta o máximo de captação tumoral com o mínimo de acúmulo nos tecidos sadios, ainda não foi descrito e seu aprimoramento constitui-se em contribuição de suma importância para diagnóstico e tratamento de tumores que superexpressam GRPr em pesquisa médica. 


\section{MATERIAIS E MÉTODOS}

\subsection{Planejamento Experimental}

Os derivados da bombesina envolvidos neste trabalho foram planejados por estudos de modelagem molecular, com base nas estruturas e resultados de análogos da bombesina descritos na literatura, e foram sintetizados complexados ao agente quelante DOTA (ácido 1,4,7,10-tetraazaciclododecano-tetraacético) por uma empresa especializada em síntese de peptídeos.

Estudos preliminares foram realizados para determinar os parâmetros da reação de marcação que conferiam maior pureza radioquímica aos derivados radiomarcados. Os parâmetros avaliados foram a massa de peptídeo e a atividade de cloreto de lutécio-177, e as reações se processaram a alta temperatura e em $\mathrm{pH}$ ácido, características das reações de complexação do ${ }^{177} \mathrm{Lu}$ com o grupamento quelante DOTA. Definidos os parâmetros, os derivados foram radiomarcados e a análise da pureza radioquímica foi realizada por cromatografia em camada delgada e confirmada por cromatografia líquida de alta eficiência (CLAE) em coluna de fase reversa $\left(\mathrm{C}_{18}\right)$.

Uma vez obtidos os derivados radiomarcados com pureza radioquímica maior ou igual a 95\%, exigência das farmacopéias americana e europeia, fez-se a análise da estabilidade dos derivados após armazenamento em geladeira $\left(2-8^{\circ} \mathrm{C}\right)$ e incubação em soro humano a $37^{\circ} \mathrm{C}$. O coeficiente de partição experimental dos derivados radiomarcados também foi determinado, a fim de, juntamente com os tempos de retenção em CLAE, predizer comparativamente sua lipossolubilidade.

Realizados os estudos in vitro, procedeu-se à caracterização biológica dos derivados radiomarcados. Foram realizados estudos de biodistribuição, farmacocinética e corpo inteiro em camundongos sadios para elucidar quais são os órgãos-alvo, a via de excreção, a cinética sanguínea, a retenção e eliminação dos radiofármacos do organismo e propor os compartimentos em que são distribuídos. Para avaliar o potencial dos radiofármacos para diagnóstico e tratamento tumoral, um modelo animal de câncer de próstata foi desenvolvido em camundongos Nude. Estudos de biodistribuição também foram realizados nesses camundongos e a ligação dos derivados ao tumor foi analisada de forma comparativa, bem como a ligação aos órgãos-alvo. Com base nos resultados desses 
estudos, realizaram-se estudos de competição in vivo com os derivados que apresentaram maior captação tumoral, a fim de conhecer a especificidade da ligação dos derivados às células tumorais. As imagens cintilográficas foram adquiridas em camundongos Balb-c, para confirmar o perfil de biodistribuição, e em camundongos Nude com tumor de células PC-3, para analisar a capacidade de detecção tumoral dos derivados radiomarcados com ${ }^{177} \mathrm{Lu}$.

Finalmente, estudos do efeito dos derivados não radiomarcados sobre as células PC-3 in vitro foram realizados, a fim de predizer se os derivados da bombesina em estudo são agonistas ou antagonistas dos receptores GRP.

Na FIG. 10 apresenta-se um esquema do planejamento experimental deste trabalho.

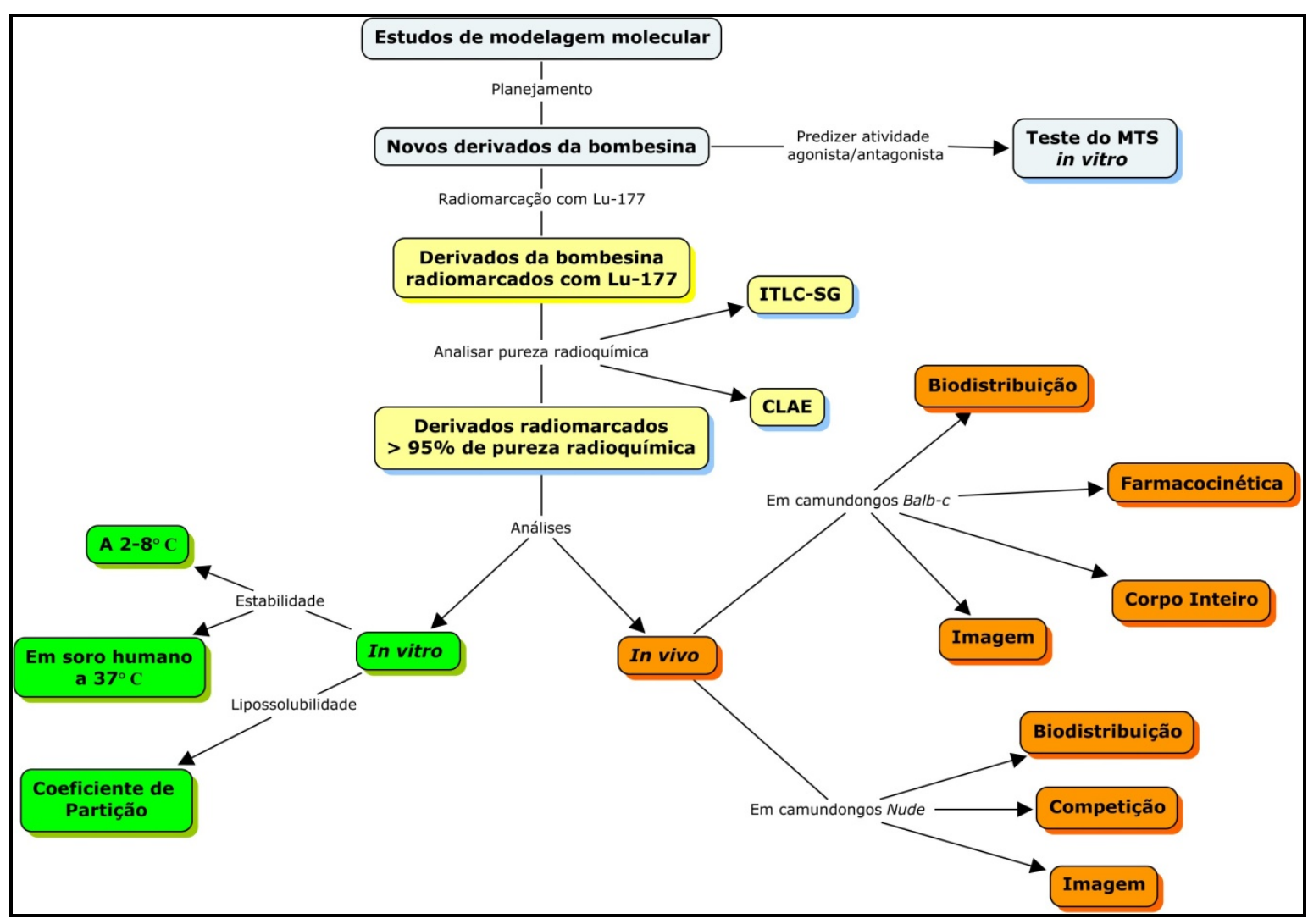

FIGURA 10 - Esquema do planejamento experimental deste trabalho. 


\subsection{Materiais}

\subsubsection{Infraestrutura}

Os ensaios foram realizados nos laboratórios de Pesquisa e Desenvolvimento de Radiofármacos no Centro de Radiofarmácia da Diretoria de Radiofarmácia, no laboratório de Cultivo Celular do Centro de Biotecnologia (CB) e no Biotério, todas as dependências sitiadas na área do IPEN. Esses laboratórios forneceram toda a infraestrutura necessária para a manipulação de materiais radioativos, células e animais, respectivamente.

\subsubsection{Reagentes}

Os principais reagentes utilizados neste trabalho foram:

$\checkmark$ Peptídeos derivados da bombesina (piCHEM, Áustria);

$\checkmark$ cloreto de lutécio-177 (IBD, Holanda);

$\checkmark$ acetato de sódio anidro (Nuclear, Brasil);

$\checkmark$ ácido cítrico (Cromato Produtos Químicos, Brasil);

$\checkmark$ citrato de sódio diidratado (J. T. Baker, EUA);

$\checkmark$ acetonitrila (Merck, Alemanha);

$\checkmark$ ácido trifluoroacético (Sigma Aldrich, EUA);

$\checkmark$ água Milli-Q (Purificador Milli-RX 45 Millipore, EUA);

$\checkmark$ resina Chellex $100($ BioRad, EUA);

$\checkmark$ n-octanol p.a. (Merck, Alemanha);

$\checkmark$ metanol (Merck, Alemanha);

$\checkmark$ etanol (Merck, Alemanha);

$\checkmark$ células PC-3 de adenocarcinoma de próstata humano (Hemocentro da UNICAMP, Brasil);

$\checkmark$ meio de cultura RPMI 1640 (Cultilab, Brasil);

$\checkmark$ soro fetal bovino (Cultilab, Brasil);

$\checkmark$ tripsina bovina (Cultilab, Brasil);

$\checkmark$ penicilina:estreptomicina (Gibco-Invitrogen, EUA);

$\checkmark$ matrigel alta concentração (BD-Biosciences, EUA);

$\checkmark$ MTS [3(4,5-dimetiltiazol-2-il)-5(3-carboximetoxifenil)-2-(4-sulfofenil)-2H-tetrazolina] (Promega Corp., Madison, WI, EUA),

$\checkmark$ fenazina meosulfato (Sigma, Saint Louis, MO, EUA). 


\subsubsection{Materiais, equipamentos e sistemas}

Os principais materiais, equipamentos e sistemas utilizados neste trabalho foram:

$\checkmark$ Balança analítica (M220 - Denver Instrument, EUA);

$\checkmark$ balança semi-analítica (LT Lutron, EUA);

$\checkmark$ centrífuga (Himac Hitachi, Japão);

$\checkmark$ agitador/aquecedor Thermomixer comfort 1,5 mL (Eppendorf, EUA);

$\checkmark$ agitador de tubos tipo vortex (Vertex, Brasil);

$\checkmark$ medidor de $\mathrm{pH}$ (Tecnopon, Brasil)

$\checkmark$ agitador magnético com aquecimento (725A Fisatom, Brasil);

$\checkmark$ mini-coluna de extração em fase reversa Sep-Pak $\mathrm{C}_{18}$ (Waters, EUA);

$\checkmark$ pipetas automáticas (Brand e Socorex);

$\checkmark$ calibrador de atividade $\left(\mathrm{CRM}^{\mathrm{TM}}-35 \mathrm{R}\right.$ - Capintec, EUA);

$\checkmark$ contador automático tipo poço com cristal NaI(TI) (D5002 cobra II - PackardCanberra, EUA);

$\checkmark$ suporte cromatográfico para cromatografia em camada delgada - ITLC-SG (Pall Life Sciences, EUA);

$\checkmark$ cromatógrafo líquido de alta eficiência composto por sistema modulado constituído por bomba LC-10 ATvp, controlador automático de gradiente FCV-10 AL, degaseificador DGU-20A 5 , injetor automático de amostras SIL-10ADvp, detector UV SPD-10A e forno CTO-10 Avp (Shimadzu, Japão);

$\checkmark$ detector radioativo (câmara de cintilação - NaI) do sistema CLAE (Shell Jr. 1000/2000, Shell-usa, EUA);

$\checkmark$ coluna de fase reversa $C_{18}$ para cromatografia líquida de alta eficiência $(4.0$ x $150 \mathrm{~mm}$, $5 \mu \mathrm{m}$ - Waters, EUA);

$\checkmark$ gama câmara com colimador de baixa energia e alta resolução e matrix 256 × 256 x 16 (Mediso Imaging System, Hungria);

$\checkmark$ leitor de microplacas (Dynatech, Model MR4000, Chantilly, VA, EUA);

$\checkmark$ microscópio óptico (E100, Nikon, Japão);

$\checkmark$ equipamento de osmose reversa (Purificador Milli-RX 45 Millipore, EUA);

$\checkmark$ membrana filtrante de poliestireno, hidrofílica, poro de 0,22 $\mu$ m (Millipore, EUA);

$\checkmark$ membrana filtrante de teflon, hidrofóbica, poro de $0,22 \mu \mathrm{m}$ (Millipore, EUA);

$\checkmark$ programa Biexp (México); 
programa estatístico Prisma 5.0 (GraphPad Software, Inc., EUA);

$\checkmark$ vidraria em geral, tais como béqueres, erlemeyers, balões volumétricos, provetas e pipetas;

$\checkmark$ material plástico descartável em geral, tais como ponteiras, seringas, tubos tipo eppendorf, tubos cônicos tipo Falcon, criotubos e placas de cultura.

\subsubsection{Tampões e soluções}

Os principais tampões e soluções utilizados neste trabalho foram:

$\checkmark$ Tampão acetato de sódio $0,4 \mathrm{M} \mathrm{pH} \mathrm{4,5;}$

$\checkmark$ tampão citrato $0,1 \mathrm{M} \mathrm{pH} \mathrm{5,0;}$

$\checkmark$ ácido trifluoroacético $0,1 \%$ em água;

$\checkmark$ ácido trifluoroacético $0,1 \%$ em acetonitrila;

$\checkmark$ solução salina $(\mathrm{NaCl}) 0,9 \%$;

$\checkmark$ tampão fosfato-salino $\mathrm{pH} 7,4$ (PBS);

$\checkmark$ matrigel alta concentração em solução salina $0,9 \%$ (1:2).

\subsubsection{Peptídeos derivados da bombesina}

As estruturas dos derivados da bombesina envolvidos neste trabalho foram arquitetadas por estudos de modelagem molecular, utilizando o Programa Sybyl 7.2 para Linux. A partir desta análise computacional alguns compostos foram selecionados para serem sintetizados, que corroborando dados de literatura originariam análogos interessantes para início das investigações de novos radiofármacos com afinidade por receptores para a bombesina. Os compostos escolhidos foram sintetizados pela piCHEM (Áustria) já complexados ao agente quelante DOTA para marcação com o ${ }^{177} \mathrm{Lu}$.

A estrutura genérica dos derivados estudados neste trabalho é DOTA-Phe-

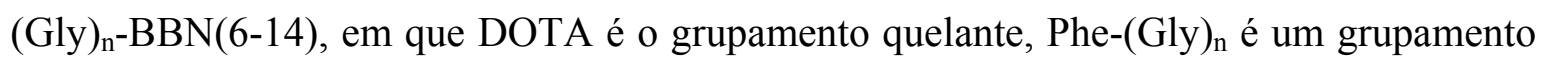
espaçador aminoacídico N-terminal modificado em relação à estrutura original da BBN e BBN(6-14) é a sequência de aminoácidos 6-14 da bombesina. Os peptídeos foram nomeados conforme o número $\mathrm{n}$ de aminoácidos glicina do grupamento espaçador $\mathrm{X}$ : se $\mathrm{n}=1$ tem-se o peptídeo $\mathrm{BEFG}_{1}$, se $\mathrm{n}=2$ tem-se o peptídeo $\mathrm{BEFG}_{2}$, se $\mathrm{n}=3$ tem-se o peptídeo $\mathrm{BEFG}_{3}$, se $\mathrm{n}=4$ tem-se o peptídeo $\mathrm{BEFG}_{4}$ e se $\mathrm{n}=5$ tem-se o peptídeo $\mathrm{BEFG}_{5}$. As estruturas desses derivados da bombesina após a complexação com o ${ }^{177} \mathrm{Lu}$ são mostradas nas FIG. $11,12,13,14$ e 15 , respectivamente. 


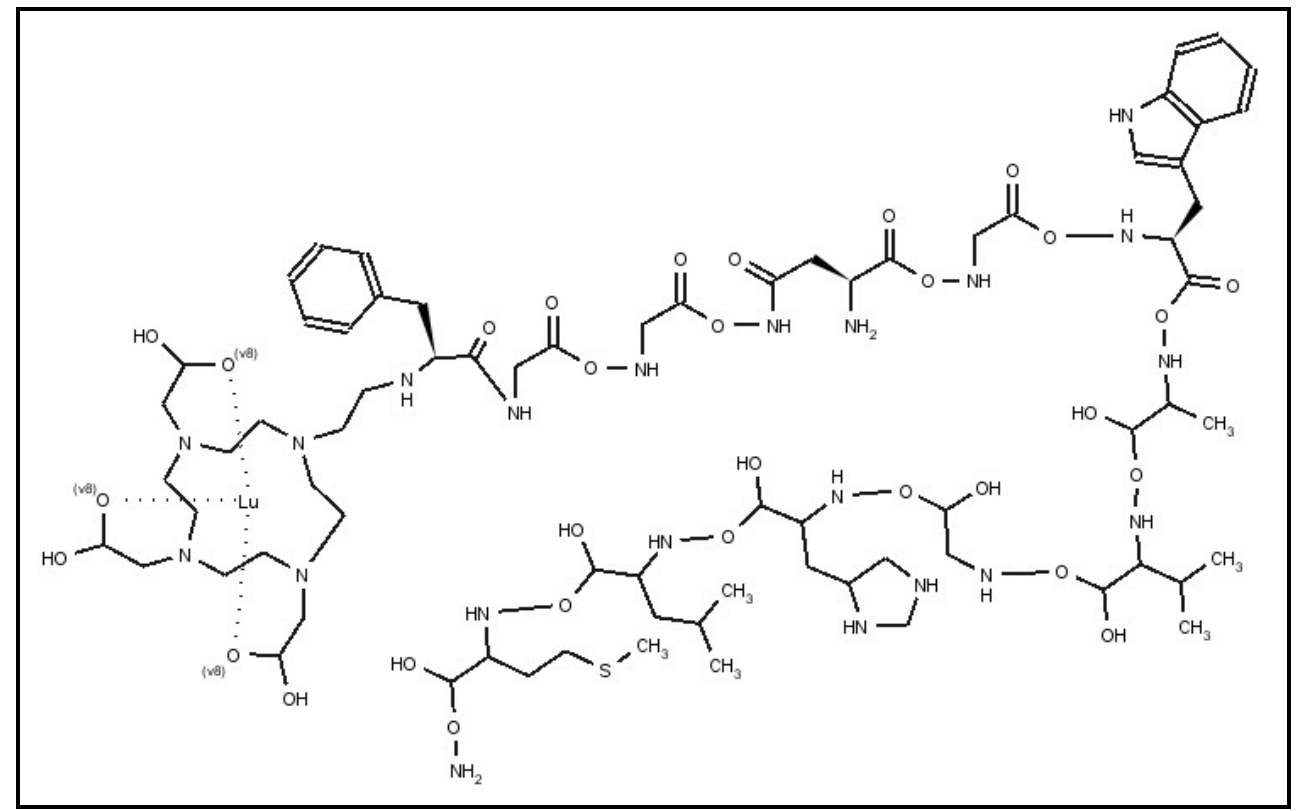

FIGURA 11 - Estrutura do derivado DOTA-Phe-(Gly) ${ }_{1}$-Asn-Gln-Trp-Ala-Val-Gly-HisLeu-Met- $\mathrm{NH}_{2}\left(\mathrm{BEFG}_{1}\right)$ após a complexação com ${ }^{177} \mathrm{Lu}$.

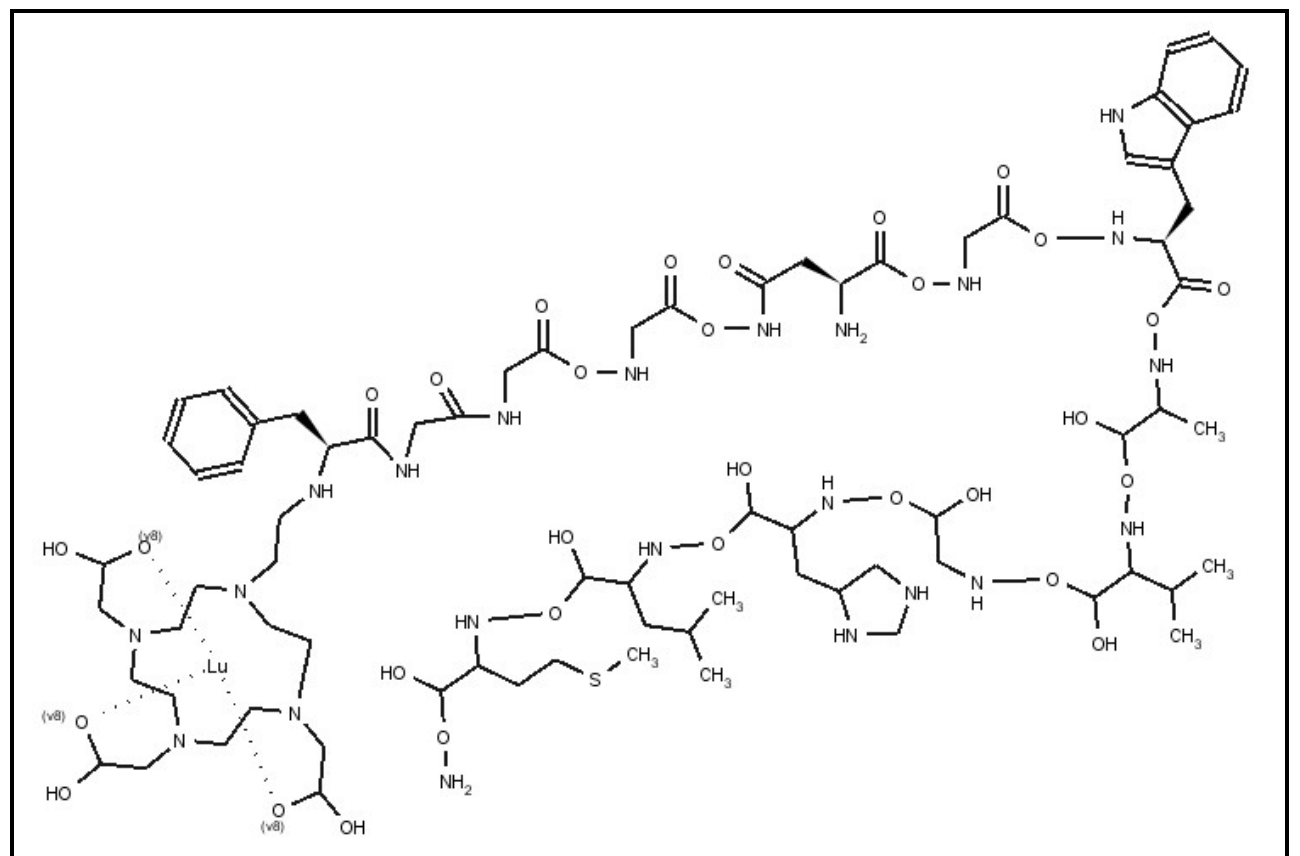

FIGURA 12 - Estrutura do derivado DOTA-Phe-(Gly)2-Asn-Gln-Trp-Ala-Val-Gly-HisLeu-Met- $\mathrm{NH}_{2}\left(\mathrm{BEFG}_{2}\right)$ após a complexação com ${ }^{177} \mathrm{Lu}$. 


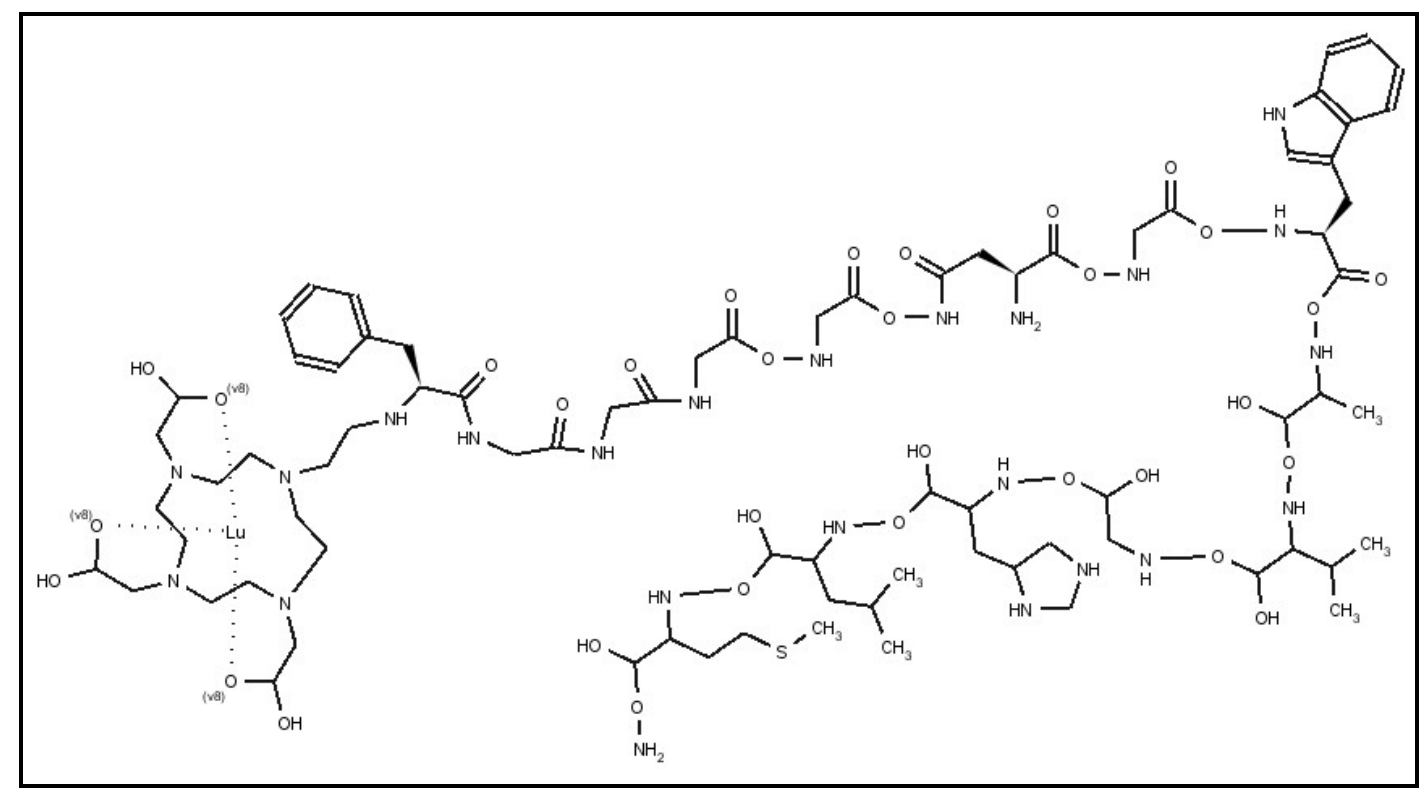

FIGURA 13 - Estrutura do derivado DOTA-Phe-(Gly) $)_{3}$-Asn-Gln-Trp-Ala-Val-Gly-HisLeu-Met- $\mathrm{NH}_{2}\left(\mathrm{BEFG}_{3}\right)$ após a complexação com ${ }^{177} \mathrm{Lu}$.

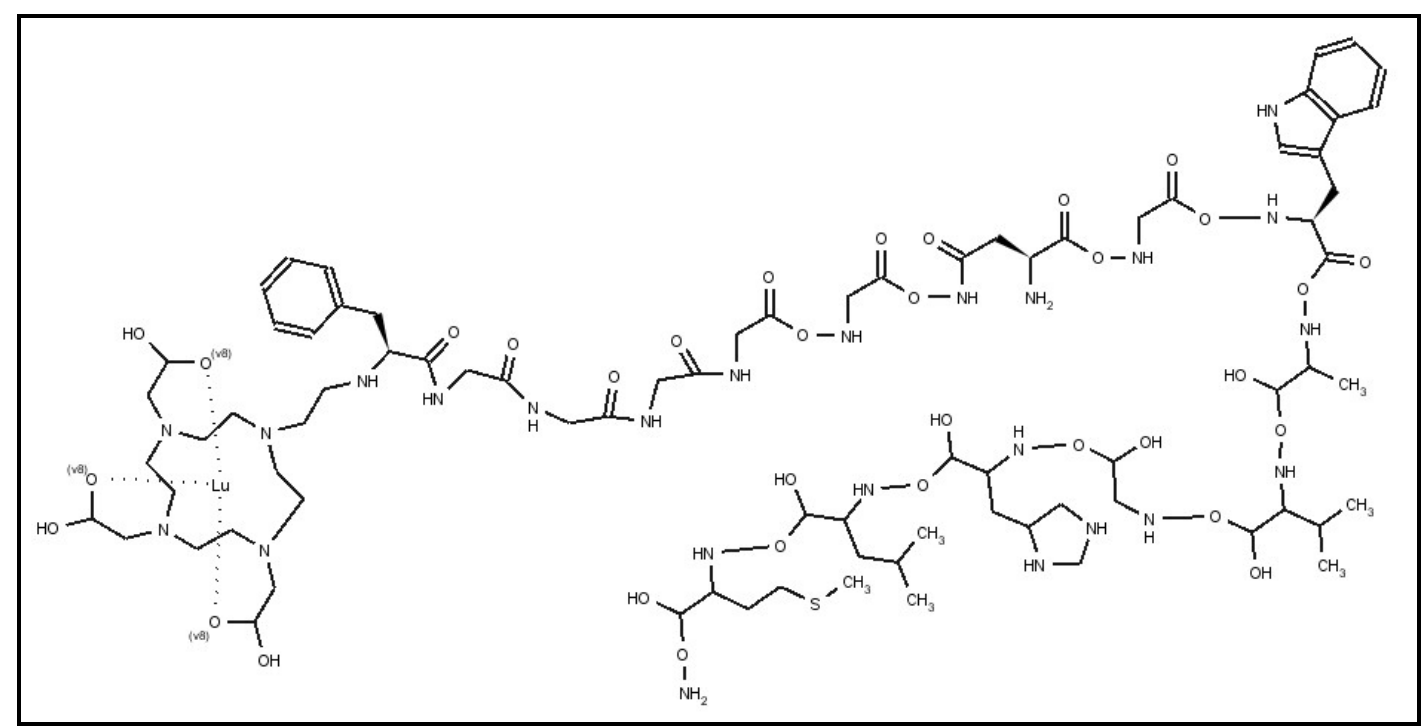

FIGURA 14 - Estrutura do derivado DOTA-Phe-(Gly)4-Asn-Gln-Trp-Ala-Val-Gly-HisLeu-Met- $\mathrm{NH}_{2}\left(\mathrm{BEFG}_{4}\right)$ após a complexação com ${ }^{177} \mathrm{Lu}$. 


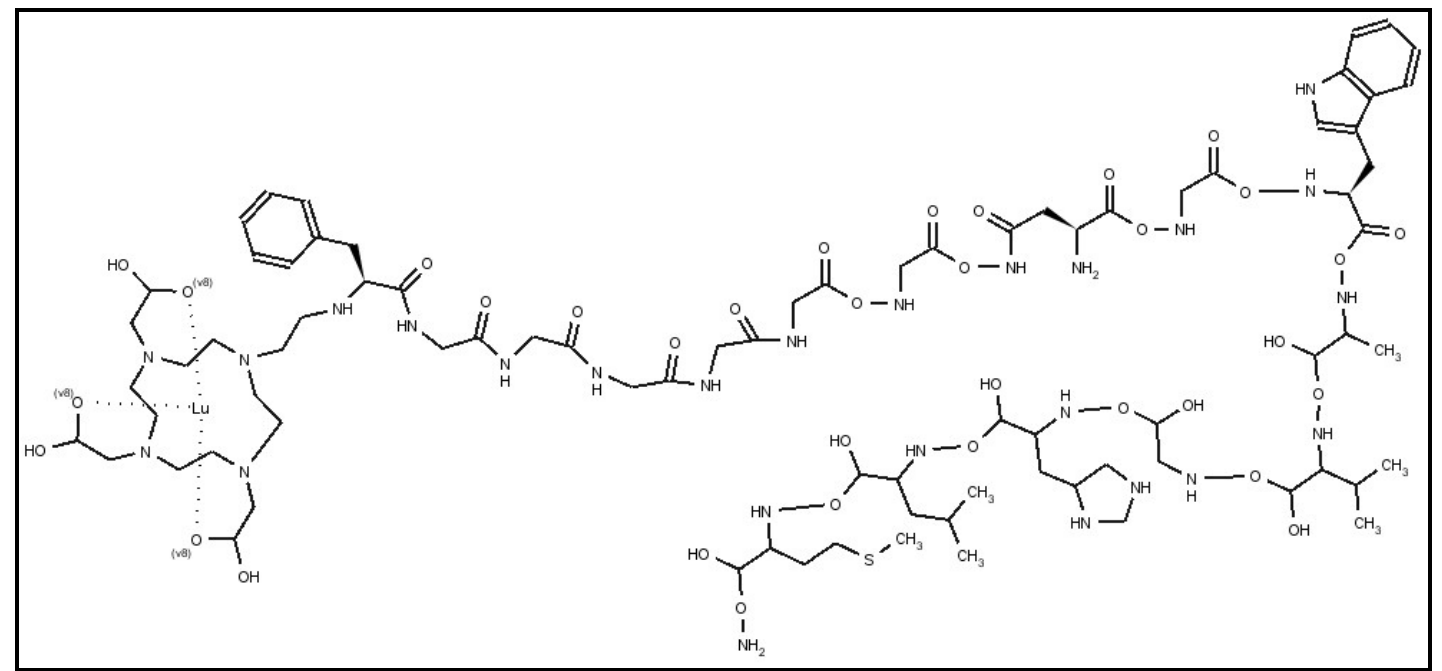

FIGURA 15 - Estrutura do derivado DOTA-Phe-(Gly)5-Asn-Gln-Trp-Ala-Val-Gly-HisLeu-Met- $\mathrm{NH}_{2}\left(\mathrm{BEFG}_{5}\right)$ após a complexação com ${ }^{177} \mathrm{Lu}$.

\subsubsection{Animais}

Os estudos in vivo foram realizados em camundongos Balb-c e Nude machos, de quatro a oito semanas de idade e 20 a 25 gramas de peso (Biotério - IPEN). Todos os experimentos foram previamente aprovados pelo Comitê de Ética em Pesquisa do IPEN e realizados de acordo com as normas estabelecidas pela Sociedade Brasileira de Ciência em Animais de Laboratório (SBCAL).

\subsubsection{Células PC-3 de adenocarcinoma de próstata humano}

As células PC-3, derivadas de adenocarcinoma de próstata humano, foram cultivadas a $37^{\circ} \mathrm{C}$ e $5 \%$ de $\mathrm{CO}_{2}$ em meio de cultura RPMI 1640 enriquecido com $10 \%$ de soro fetal bovino (SFB) e $1 \%$ de penicilina:estreptomicina. Ao atingirem $80 \%$ de confluência na placa de cultura (FIG. 16), as células foram tripsinizadas e ressuspendidas em solução e concentração variadas, conforme o ensaio realizado. 


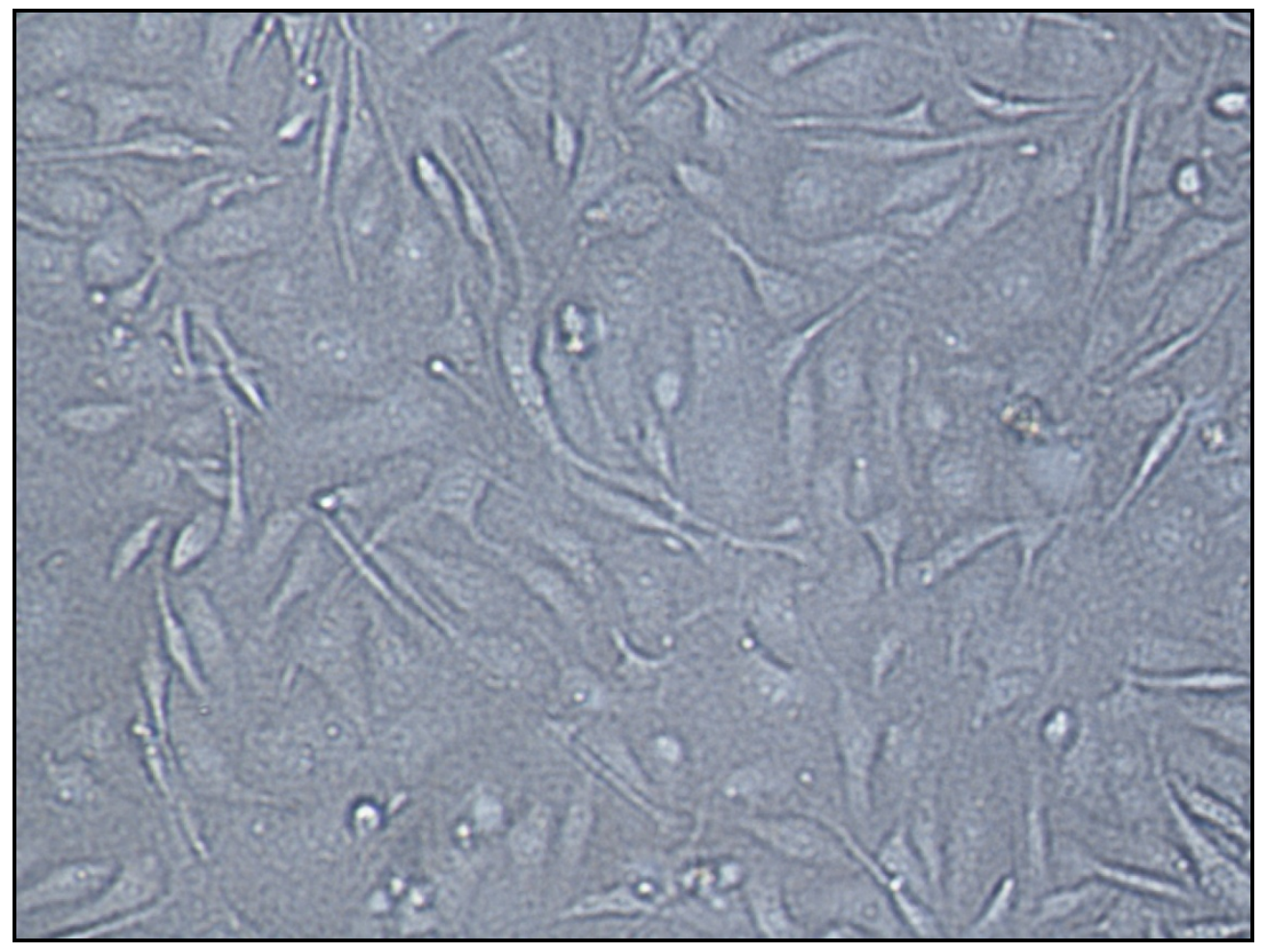

FIGURA 16 - Foto de microscópio óptico das células PC-3 derivadas de adenocarcinoma de próstata humano em $80 \%$ de confluência na placa de cultura (Aumento: $10000 \mathrm{x}$ ).

\subsection{Métodos}

\subsubsection{Radiomarcação dos derivados da bombesina com lutécio-177}

Estudos preliminares foram realizados a fim de estabelecer a melhor condição de marcação dos derivados, com base nos resultados de Breeman e colaboradores (apud de Araújo et al., 2009) para radiomarcação de um derivado de somatostatina com ${ }^{177} \mathrm{Lu}$. Esses estudos foram realizados com o derivado de massa intermediária $\left(\mathrm{BEFG}_{3}\right)$. Variou-se a massa do derivado (10 e $20 \mu \mathrm{g}$ ) e a atividade de lutécio (37 a $185 \mathrm{MBq}$ ), mantendo-se a temperatura de reação a $90^{\circ} \mathrm{C}, \mathrm{o}$ pH do meio 4,5, o tempo de reação em 30 minutos e o volume de reação em $200 \mu \mathrm{L}$. Todos os reagentes utilizados nas reações foram preparados com água purificada por equipamento de osmose reversa e tratada com resina Chelex 100 para remoção de íons metálicos.

Adicionou-se a $20 \mu \mathrm{g}$ de cada derivado $92,5 \mathrm{MBq}(2,5 \mathrm{mCi})$ de ${ }^{177} \mathrm{LuCl}_{3}(704-$ $934 \mathrm{GBq} / \mathrm{mg}$ ) e ajustou-se o volume para $200 \mu \mathrm{L}$ com tampão acetato de sódio $0,4 \mathrm{M}$ pH 4,5. A mistura de reação foi então incubada por 30 minutos, a $90^{\circ} \mathrm{C}$ e agitação de $350 \mathrm{rpm}$ e a pureza radioquímica foi analisada conforme descrito a seguir. 


\subsubsection{Análise da pureza radioquímica dos derivados radiomarcados}

A pureza radioquímica é definida como a porcentagem do total da radioatividade que se encontra na forma química desejada, ou seja, de peptídeos marcados com lutécio-177. O controle de pureza radioquímica da marcação dos derivados da BBN foi avaliado por dois sistemas cromatográficos para pesquisar a presença de radiolantanídeo não ligado $\left({ }^{177} \mathrm{LuCl}_{3}\right)$ : a cromatografia em camada delgada em sílica gel 60 (ITLC-SG) e a cromatografia líquida de alta eficiência (CLAE).

\subsubsection{Cromatografia ascendente em camada delgada em sílica gel 60 (ITLC-SG)}

Aplicou-se uma alíquota da mistura de radiomarcação sobre o suporte de ITLC-SG (1,5 x $10 \mathrm{~cm})$ e procedeu-se à cromatografia utilizando como fase móvel tampão citrato/ácido cítrico 0,1 M pH 5,0. Em seguida, cortou-se as fitas de ITLC-SG em 10 segmentos de $1 \mathrm{~cm}$ e a radioatividade foi determinada no contador automático tipo poço devidamente calibrado para o radioisótopo. Nesse sistema, o peptídeo radiomarcado migra com fator de retenção $\left(R_{\mathrm{f}}\right) 0,1-0,3$, enquanto o ${ }^{177} \mathrm{Lu}$ não ligado migra com $\mathrm{R}_{\mathrm{f}} 0,9-1,0$ (de Araújo et al., 2009). Os experimentos foram realizados em sextuplicata.

\subsubsection{Cromatografia líquida de alta eficiência (CLAE)}

A análise da pureza radioquímica dos derivados radiomarcados por CLAE foi realizada conforme descrito por $\mathrm{Hu}$ e colaboradores (2002), salvo algumas modificações. Procedeu-se à cromatografia em fase reversa em um sistema Shimadzu equipado com uma coluna de fase reversa $\mathrm{C}_{18}$ (Waters, $150 \mathrm{~mm}$ x 4,0 mm, $5 \mu \mathrm{m}$ ) e detector de radiação gama (Shell Jr). O fluxo utilizado foi de $1,5 \mathrm{~mL} /$ minuto com gradiente linear de 10 a $90 \%$ (v/v) de TFA: $\mathrm{CH}_{3} \mathrm{CN}(1: 1000 \mathrm{v} / \mathrm{v})$ em TFA:H $\mathrm{H}_{2} \mathrm{O}(1: 1000 \mathrm{v} / \mathrm{v})$ por 15 minutos, retornando ao estado inicial por cinco minutos para estabilização do sistema. Analisou-se também, para fins comparativos, o perfil do ${ }^{177} \mathrm{LuCl}_{3}$ pelo mesmo sistema e dos peptídeos não radiomarcados utilizando detector UV 190 - $300 \mathrm{~nm}$ (Shimadzu) e comprimento de onda $280 \mathrm{~nm}$.

\subsubsection{Análise da estabilidade dos derivados radiomarcados}

A estabilidade dos derivados radiomarcados foi analisada após incubação a 2$8^{\circ} \mathrm{C}$ em geladeira e a $37^{\circ} \mathrm{C}$ em soro humano. 


\subsubsection{Análise da estabilidade à $2-8^{\circ} \mathrm{C}$}

Incubou-se as misturas de radiomarcação (92,5 MBq do derivado radiomarcado em $200 \mu \mathrm{L}$ de tampão acetato de sódio $0,4 \mathrm{M}$ pH 4,5) à 2-8 $\mathrm{C}$ em geladeira por até 7 dias (168 horas), retirando-se uma alíquota após 24, 48, 72, 96 horas e 168 horas para análise da pureza radioquímica por cromatografia em ITLC-SG, conforme descrito anteriormente. Os ensaios foram realizados em triplicata.

\subsubsection{Análise da estabilidade em soro humano à $37^{\circ} \mathrm{C}$}

Para obtenção do soro humano, coletou-se $10 \mathrm{~mL}$ de sangue de doador sadio sem anticoagulante, centrifugou-se a 1400 g por 10 minutos, separou-se o coágulo de fibrina e centrifugou-se novamente para separação do soro.

Adicionou-se, em triplicata, $1 \mathrm{~mL}$ do soro humano a $24 \mathrm{MBq}$ de cada derivado radiomarcado e incubou-se à $37^{\circ} \mathrm{C}$ sob agitação de $350 \mathrm{rpm}$ por 1,4 e 24 horas. Decorrido o tempo, retirou-se uma alíquota das misturas para análise por cromatografia em camada delgada, conforme descrito anteriormente. O mesmo procedimento foi realizado para determinação da estabilidade do ${ }^{177} \mathrm{LuCl}_{3}$ em soro humano. Os perfis cromatográficos obtidos para os derivados radiomarcados em cada tempo foram comparados ao perfil do derivado imediatamente após sua diluição em soro e ao perfil do ${ }^{177} \mathrm{LuCl}_{3}$ no tempo correspondente.

\subsubsection{Determinação do coeficiente de partição experimental dos derivados radiomarcados $(\mathrm{CP})$}

O coeficiente de partição dos derivados radiomarcados foi determinado conforme descrito por Durkan e colaboradores (2007), a fim de avaliar comparativamente a lipossolubilidade dos derivados. Adicionou-se, em triplicata, $50 \mu \mathrm{L}(24 \mathrm{MBq})$ dos peptídeos radiomarcados a um tubo contendo $3 \mathrm{~mL}$ de n-octanol e $3 \mathrm{~mL}$ de água destilada, pré-saturados por 24 horas. Agitou-se o tubo por uma hora à temperatura ambiente e, após a separação das fases aquosa e oleosa, coletou-se $10 \mu \mathrm{L}$ da fase aquosa e $100 \mu \mathrm{L}$ da fase oleosa para contagem em contador automático tipo poço. O coeficiente de partição (CP) foi determinado pela equação:

$$
C P=\log _{10}\left[\frac{\text { cpm fase oleosa }}{\text { cpm fase aquosa } \times 10}\right]
$$




\subsubsection{Estudos in vivo}

\subsubsection{Estudos de biodistribuição em camundongos Balb-c sadios}

Os estudos de biodistribuição foram realizados utilizando o método invasivo. Injetou-se por via endovenosa caudal $0,185 \mathrm{MBq}(50 \mu \mathrm{Ci})$ dos derivados radiomarcados diluídos em $100 \mu \mathrm{L}$ de solução salina $0,9 \%$. Após 1, 4 ou 24 horas os animais foram sacrificados por decapitação, os principais tecidos foram retirados e pesados e avaliou-se a radioatividade em um contador gama tipo poço. Calcularam-se as porcentagens da atividade injetada por tecido (\% AI, EQ. 2) e por grama de tecido (\% AI/g, EQ. 3) utilizando-se a média das contagens da triplicata de um padrão da atividade administrada. Os ensaios foram realizados em quintuplicata.

$$
\% \mathrm{Al}=\frac{\mathrm{cpm} \text { órgão }}{\mathrm{cpm} \text { padrão }} \times 100
$$

$$
\% \mathrm{Al} / \mathrm{g}=\frac{\mathrm{cpm} \text { órgão }}{\text { peso órgão }(\mathrm{g}) \times \mathrm{cpm} \text { padrão }} \times 100
$$

Para cálculo da porcentagem de atividade injetada presente nos ossos (\% $\mathrm{AI} /$ osso) e nos músculos (\% $\mathrm{AI} /$ músculo) dos animais, retirou-se o fêmur e o músculo da coxa dos camundongos, calculou-se a porcentagem de atividade por grama e assumiu-se o peso do esqueleto como $12 \%$ (EQ. 4) e dos músculos como $40 \%$ (EQ. 5) do peso corpóreo do camundongo (Jiménez, 2007).

$$
\% \mathrm{Al} / \text { osso }=\frac{\mathrm{cpm} \text { fêmur } \times 12 \times \text { peso do camundongo }(\mathrm{g})}{\text { peso do fêmur }(\mathrm{g}) \times \mathrm{cpm} \text { padrão }}
$$

$\% \mathrm{Al} /$ músculo $=\frac{\mathrm{cpm} \text { músculo } \mathrm{x} 40 \times \text { peso do camundongo }(\mathrm{g})}{\text { peso do músculo }(\mathrm{g}) \times \mathrm{cpm} \text { padrão }}$ 


\subsubsection{Estudos farmacocinéticos em camundongos Balb-c sadios}

Denomina-se farmacocinética a relação entre a administração de um fármaco, sua distribuição no decorrer do tempo e a concentração alcançada nas diferentes partes do organismo (Wilkinson, 2003). A farmacocinética estabelece relações muito estreitas com a farmacodinâmica. Esta, fundamentalmente, estuda os mecanismos de ação dos fármacos e seus efeitos farmacológicos. O conhecimento farmacocinético de um fármaco determina, entre outros, dados importantes como: (a) condições para seu uso adequado; (b) previsão de outros efeitos em potencial, como, por exemplo, efeitos adversos, especialmente no caso de acúmulo do fármaco em um determinado compartimento; (c) determinação dos mais importantes sítios de biotransformação; (d) determinação das vias de eliminação (Lara, 1985).

No estudo farmacocinético é de grande importância o conceito de compartimento, que tem conotação puramente matemática e nem sempre corresponde a espaço orgânico definido. Exemplo disto é a distribuição, após determinado tempo, de um fármaco na água total do corpo. Como a água é constituinte de todos os elementos orgânicos, o compartimento da água total do organismo é enorme e supera numericamente os valores definidos do volume plasmático ou do volume sanguíneo (Lara, 1985).

A análise da farmacocinética dos derivados radiomarcados foi realizada por método não invasivo. Injetou-se por via endovenosa caudal $0,185 \mathrm{MBq}(50 \mu \mathrm{Ci})$ dos derivados radiomarcados diluídos em $100 \mu \mathrm{L}$ de solução salina $0,9 \%$ e, após diferentes tempos (1 minuto a 24 horas), coletou-se $60 \mu \mathrm{L}$ de sangue pelo plexo orbital dos camundongos utilizando um tubo capilar heparinizado. A radioatividade no sangue foi determinada utilizando-se a média das contagens da triplicata de um padrão da atividade administrada e foi expressa em porcentagem da atividade injetada por mililitro de sangue (\% AI/mL sangue, EQ. 6) e em porcentagem da atividade injetada no sangue total (\% $\mathrm{AI} /$ sangue, EQ. 7). Os ensaios foram realizados em quintuplicata.

$$
\% \mathrm{Al} / \mathrm{mL} \text { sangue }=\frac{\mathrm{cpm} \text { sangue coletado }}{\mathrm{cpm} \text { padrão } \times 0,06} \times 100
$$

$$
\% \mathrm{Al} / \text { sangue }=\frac{\text { cpm sangue coletado }}{\text { cpm padrão } \times 0,06} \times \text { Volemia } \times 100
$$


O volume total de sangue (volemia) do camundongo foi assumido como 7,78\% do seu peso corpóreo (EQ. 8) (Jiménez, 2007).

$$
\text { Volemia }(\mathrm{mL})=\text { Peso do camundongo }(\mathrm{g}) \times 0,0778
$$

Os parâmetros farmacocinéticos foram calculados utilizando-se o programa Biexp (Murphy e Tonantzintla, 1991). Este programa é útil para modelar dados experimentais de decaimento radioativo, por meio de um modelo matemático de distribuição bicompartimental, que aproxima o clareamento sanguíneo para um modelo com duas exponenciais, uma de decaimento rápido e outra de decaimento lento.

\subsubsection{Estudos de corpo inteiro em camundongos Balb-c sadios}

A fim de predizer a excreção e o tempo de residência no organismo dos derivados da bombesina, estudos de corpo inteiro foram realizados em camundongos Balbc sadios. Injetou-se por via endovenosa caudal $37 \mathrm{MBq}(1 \mathrm{mCi})$ dos derivados radiomarcados diluídos em $100 \mu \mathrm{L}$ de solução salina $0,9 \%$. Decorridos 30 minutos, 1, 2,5, 4, 24, 96 e 144 horas após administração, os animais foram induzidos a urinar, imobilizados e posicionados sob o colimador na gama câmara para determinação das contagens de eventos radioativos durante três minutos. Os resultados foram expressos em porcentagem da atividade injetada presente no organismo e em porcentagem da atividade injetada eliminada em função do tempo, considerando-se como $100 \%$ a média das contagens imediatamente após a administração. Os ensaios foram realizados em quadruplicata.

\subsubsection{Estudos de biodistribuição em camundongos Nude com tumor PC-3}

Para avaliar a capacidade de ligação dos derivados da bombesina radiomarcados com ${ }^{177} \mathrm{Lu}$ às células de tumor de próstata in vivo, fez-se necessário projetar um modelo in vivo de tumor prostático orientado pela técnica proposta por Lantry e colaboradores (2006). Injetou-se $2 \times 10^{6}$ células PC-3, derivadas de adenocarcinoma de próstata humano, ressuspendidas em $100 \mu \mathrm{L}$ de uma mistura de solução salina $0,9 \%$ e matrigel alta concentração (2:1) por via subcutânea no dorso dos camundongos Nude.

A fim de verificar a composição dos tumores induzidos, alguns tumores foram retirados e submetidos à análise histológica em microscópio óptico após coloração com 
hematoxicilina/eosina, três semanas após a injeção das células, quando a massa tumoral atingiu cerca de 0,5g (FIG. 17).

Os estudos de biodistribuição foram realizados em triplicata, conforme descrito anteriormente para os camundongos Balb-c, três semanas após a injeção das células, quando a massa tumoral atingiu cerca $0,5 \mathrm{~g}$.

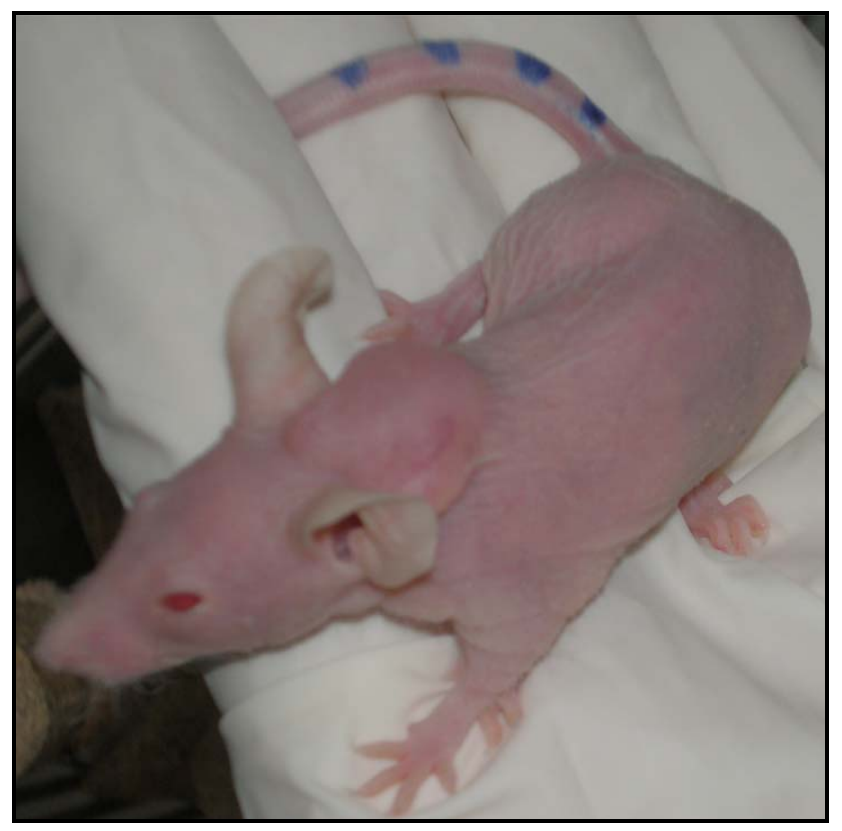

FIGURA 17 - Camundongo Nude com adenocarcinoma de próstata humano três semanas após o implante de $2 \times 10^{6}$ células PC-3 por via subcutânea.

\subsubsection{Estudos de competição em camundongos Nude com tumor PC-3}

A fim de conhecer a especificidade da ligação dos derivados da bombesina às células PC-3 in vivo, estudos de competição foram realizados com os derivados que apresentaram maior potencial de interação com os receptores nos estudos de biodistribuição. Dois grupos de três camundongos Nude com tumor PC-3 receberam uma pré-injeção do derivado não radiomarcado $(100 \mu \mathrm{g} / 100 \mu \mathrm{L} \quad 0,9 \% \mathrm{NaCl})$ por via endovenosa caudal para atuar como um bloqueador dos receptores (Biddlecombe et al., 2007). Decorridos 15 ou 45 minutos da pré-injeção, o derivado radiomarcado com ${ }^{177} \mathrm{Lu}$ $(0,185 \mathrm{MBq} / 100 \mu \mathrm{L} 0,9 \% \mathrm{NaCl}$, massa de peptídeo $0,4 \mu \mathrm{g})$ foi administrado pela mesma rota e os animais foram sacrificados por decapitação após 60 minutos. Os principais tecidos foram retirados e pesados e a radioatividade detectada em um contador gama tipo poço. Calcularam-se as porcentagens da atividade injetada por tecido e por grama de tecido e os resultados foram comparados à biodistribuição dos derivados sem a pré-injeção do peptídeo não radiomarcado. 


\subsubsection{Estudos de imagem}

Os estudos cintilográficos dos derivados radiomarcados foram realizados em camundongos Balb-c sadios e Nude com tumor PC-3, seguindo o mesmo procedimento dos estudos de corpo inteiro. Injetou-se por via endovenosa caudal $37 \mathrm{MBq}(1 \mathrm{mCi})$ dos derivados radiomarcados diluídos em $100 \mu \mathrm{L}$ de solução salina $0,9 \%$ e as imagens cintilográficas estáticas dos camundongos Balb-c em decúbito dorsal e dos camundongos Nude em decúbito lateral anestesiados com uretana $(1,2 \mathrm{mg} / \mathrm{kg}$ por via intraperitonial) foram realizadas 30 minutos, 1 hora e 4 horas após a administração dos radiofármacos. As imagens foram adquiridas utilizando a câmara de cintilação em matriz 256 x 256 por 180 segundos. O colimador utilizado foi o de baixa energia e alta resolução ("Low Energy High Resolution" - LEHR).

\subsubsection{Estudos in vitro}

\subsubsection{Efeito dos derivados da bombesina sobre a viabilidade metabólica das células PC-3}

A ligação da bombesina e seus agonistas aos receptores GRP, NMB ou $\mathrm{BB}_{3}$ nas células alvo desencadeia uma série de respostas intracelulares que têm como consequência a divisão celular por mitose, ou seja, a proliferação celular. Já a ligação dos antagonistas da bombesina aos mesmos receptores, na presença de um agonista, impede a resposta mitótica e leva à morte celular por apoptose (Stangelberger et al., 2005; Patel et al., 2006; Zhu et al., 2007; Cescato et al., 2008). Com o intuito de estabelecer o efeito dos derivados $\mathrm{BEFG}_{1}, \mathrm{BEFG}_{2}, \mathrm{BEFG}_{3}, \mathrm{BEFG}_{4}$ e $\mathrm{BEFG}_{5}$ sobre as células PC-3 in vitro e predizer uma atividade agonista ou antagonista dos receptores GRP, realizou-se o teste de proliferação celular através do ensaio com o MTS [3(4,5-dimetiltiazol-2-il)-5(3carboximetoxifenil)-2-(4-sulfofenil)-2H-tetrazolina]. O MTS é um sal de coloração amarela capaz de captar elétrons em uma reação de oxirredução, formando um produto de coloração roxa - o formazan - solúvel em água na presença de fenazina meosulfato (FIG. 18). O Formazan, por sua vez, apresenta pico de absorção em $490 \mathrm{~nm}$. Na presença de células metabolicamente ativas, o MTS é capaz de captar elétrons da cadeia transportadora de elétrons, dentre outras reações de oxirredução celulares. A medida da absorvância é uma medida do metabolismo e, consequentemente, da proliferação celular, sendo as duas grandezas diretamente proporcionais. 


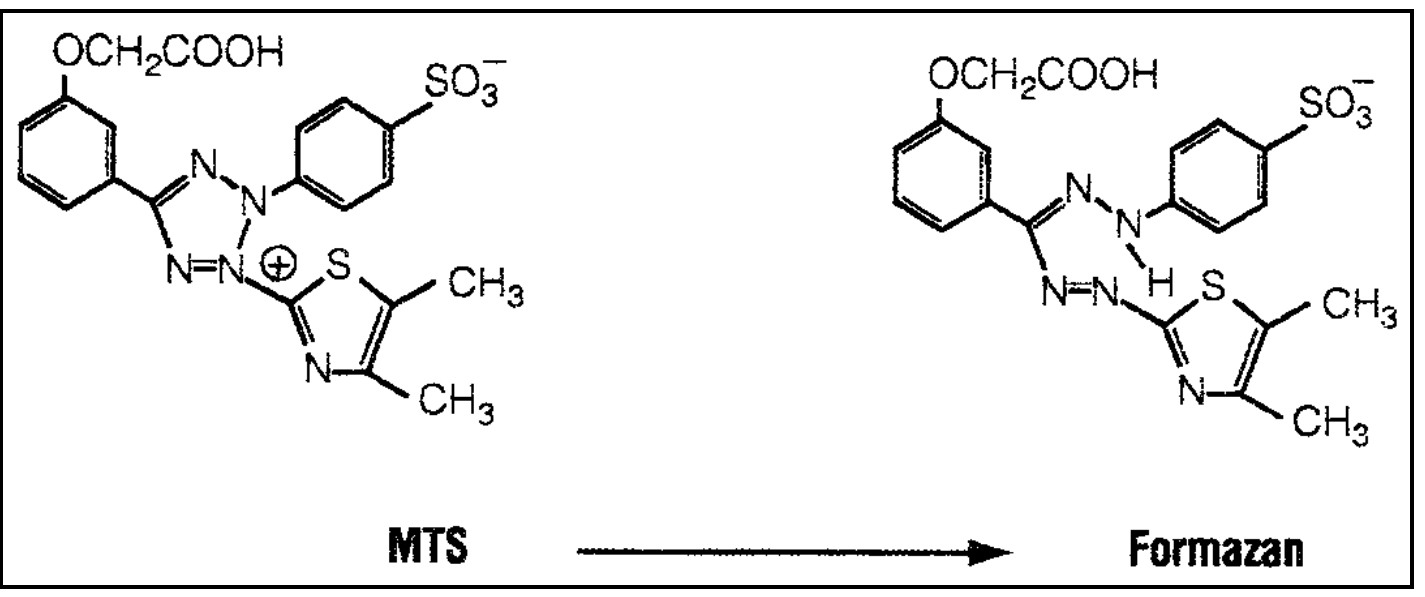

FIGURA 18 - Reação de redução do MTS a formazan.

As células PC-3 de adenocarcinoma de próstata humano foram tripsinizadas, ressuspendidas em meio de cultura RPMI 1640 contendo 1\% de soro fetal bovino, 1\% de antibiótico e diferentes concentrações dos derivados não marcados $\left(1-10^{4} \mathrm{nM}\right)$, e distribuídas em placa de 96 poços $\left(10^{4}\right.$ células/poço, $\left.200 \mu \mathrm{L}\right)$. Após 72 horas de incubação a $37^{\circ} \mathrm{C}$ e $5 \%$ de $\mathrm{CO}_{2}$, o a viabilidade celular foi avaliada por meio da coloração com o MTS (Malich et al., 1997). O MTS ( $2 \mathrm{mg} / \mathrm{mL}$ em tampão fosfato de sódio) foi misturado na proporção de 20:1 (v/v) com uma solução de fenazina meosulfato $(0,92 \mathrm{mg} / \mathrm{mL}$ em tampão fosfato de sódio). Adicionou-se $20 \mu \mathrm{L}$ dessa solução a cada poço da placa e após 1 hora de incubação a $37^{\circ} \mathrm{C}$ fez-se a leitura da absorvância no comprimento de onda de 490 nm, utilizando-se o leitor de microplacas.

\subsubsection{Análise Estatística}

Os resultados foram expressos como Média \pm Desvio Padrão. A análise estatística foi realizada através do programa estatístico PRISMA 5.0, utilizando o teste t de Student com distribuição bicaudal para comparação de pares e análise de variância ANOVA para comparação de grupos. Diferenças foram consideradas significativas quando o valor de $\mathrm{p}$ foi menor do que 0,05 . 


\section{RESULTADOS E DISCUSSÃO}

\subsection{Radiomarcação com ${ }^{177}$ Lu e determinação da pureza radioquímica dos derivados radiomarcados}

Estudos preliminares foram realizados para estabelecer a melhor condição de marcação dos derivados da bombesina. O derivado escolhido para esses estudos foi o de massa molar intermediária $\left(\mathrm{BEFG}_{3}\right)$, a fim de reduzir a variação no número de moles de peptídeos nas reações, evitando assim grandes diferenças entre as atividades específicas dos derivados radiomarcados e garantindo a reprodutibilidade do método para todos os derivados estudados.

Os resultados da pureza radioquímica das reações, determinadas por ITLC-SG, são mostrados na FIG. 19. Variou-se a massa de $\mathrm{BEFG}_{3}(10$ e $20 \mu \mathrm{g})$ e a atividade de lutécio (37 a 166,5 MBq) que reagiam em $200 \mu \mathrm{L}$ de tampão acetato de sódio $0,4 \mathrm{M}$ pH 4,5, a $90^{\circ} \mathrm{C}$ por 30 minutos, sob agitação de $350 \mathrm{rpm}$. A atividade específica do cloreto de lutécio-177 empregado nas reações variou de 704 a 934 GBq/mg. A condição que conferiu pureza radioquímica maior do que $95 \%$ associada à maior atividade específica do $\mathrm{BEFG}_{3}$ ${ }^{177} \mathrm{Lu}$ foi aquela em que se reagiu $20 \mu \mathrm{g}$ do derivado com 92,5 $\mathrm{MBq}(2,5 \mathrm{mCi}) \mathrm{de}{ }^{177} \mathrm{LuCl}_{3}$.

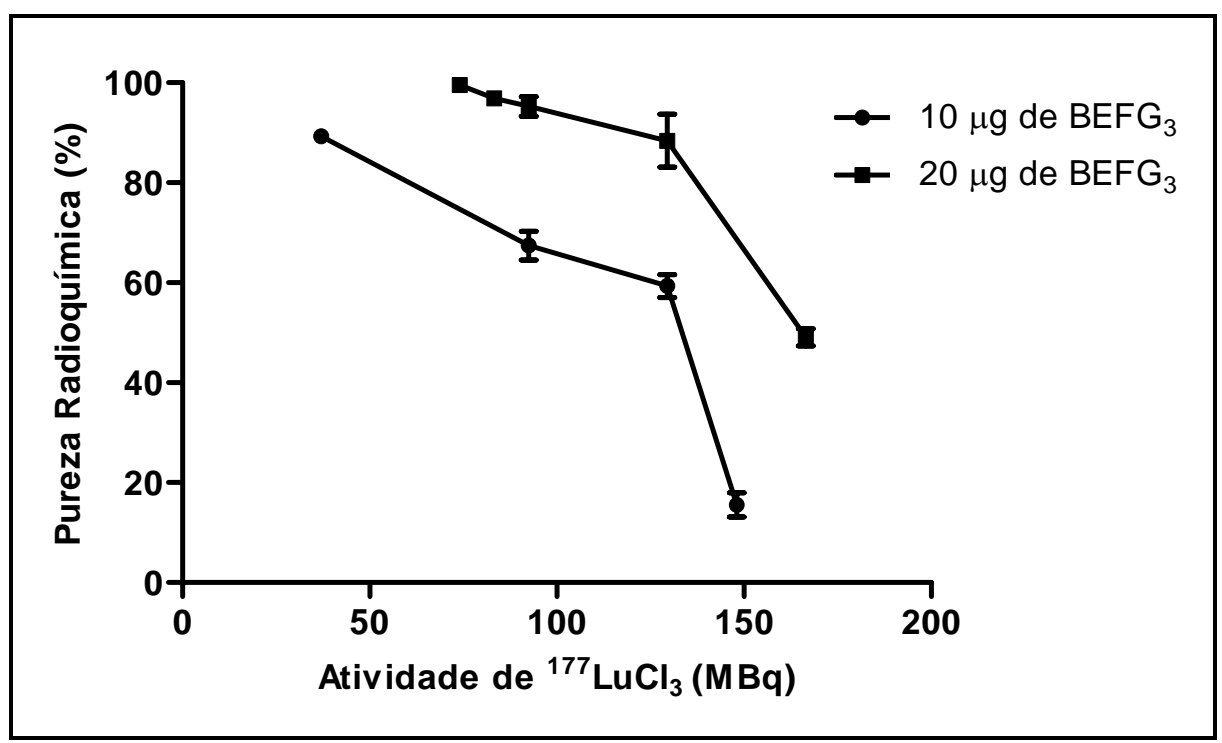

FIGURA 19 - Variação da pureza radioquímica das reações (ITLC-SG) em função da atividade de ${ }^{177} \mathrm{LuCl}_{3}(\mathrm{MBq})$ e da massa do derivado da bombesina $\mathrm{BEFG}_{3}$ ( $\mu \mathrm{g}$ ) que reagiram a $90^{\circ} \mathrm{C}$ por 30 minutos sob agitação de $350 \mathrm{rpm}(\mathrm{n}=3)$. 
Os estudos das reações de radiomarcação são importantes por possibilitar estabelecer a relação atividade de ${ }^{177} \mathrm{LuCl}_{3}$ :massa de peptídeo $(\mathrm{MBq} / \mu \mathrm{g}$ ou $\mathrm{mCi} / \mu \mathrm{g})$ que confere maior pureza radioquímica ao produto radiomarcado. Essa relação será útil para a extrapolação da condição ótima de marcação para reações envolvendo atividades maiores de cloreto de lutécio-177, compatíveis com a produção do radiofármaco para aplicações clínicas.

Na TAB. 3 apresentam-se os resultados da radiomarcação do $\mathrm{BEFG}_{3}$ e dos demais derivados da bombesina com lutécio-177, na condição otimizada nos estudos preliminares. Os dados mostram que os parâmetros definidos para o $\mathrm{BEFG}_{3}$ foram aplicados com sucesso aos demais derivados. Todos foram radiomarcados com alta pureza radioquímica (>95\%), não sendo necessário procedimento de purificação para realização dos demais estudos.

A atividade de ${ }^{177} \mathrm{LuCl}_{3}$ incorporada por unidade de massa dos peptídeos, ou seja, a atividade específica das moléculas radiomarcadas é uma grandeza importante do ponto de vista de desenvolvimento de novos radiofármacos. É desejável que a atividade específica seja alta, principalmente no caso de radiofármacos para aplicação em terapia radioisotópica, a fim de evitar a toxicidade decorrente dos efeitos fisiológicos provocados pela ligação das moléculas carreadoras aos seus receptores in vivo (Thrall e Ziessman, 2003). No caso de derivados da bombesina, a concentração mínima de agonistas ou antagonistas capaz de provocar as respostas fisiológicas in vivo ainda não foi descrita, mas in vitro alguns efeitos são observados em concentrações da ordem de nM (Levine et al., 2003; Zhu et al., 2007). A atividade específica dos derivados da bombesina radiomarcados descritos pela literatura é variável, estando em sua maioria compreendida entre 1 e 10 GBq/ $\mu \mathrm{mol}$ (Hu et al., 2002; Hoffman et al., 2003; Biddlecombe et al., 2007; Abd-Elgaliel et al., 2008). Considerando-se esta faixa, a atividade específica obtida para os derivados da bombesina radiomarcados com lutécio pode ser considerada alta e adequada para a aplicação em estudos pré-clínicos. 
TABELA 3 - Pureza radioquímica e atividade específica após a radiomarcação de $20 \mu \mathrm{g}$ dos derivados da bombesina com $2,5 \mathrm{mCi}(92,5 \mathrm{MBq})$ de ${ }^{177} \mathrm{LuCl}_{3}$ a $90^{\circ} \mathrm{C}$ por 30 minutos e $350 \mathrm{rpm}(\mathrm{n}=6)$. A pureza radioquímica foi analisada por cromatografia em camada delgada (ITLC-SG).

\begin{tabular}{ccccc}
\hline $\begin{array}{c}\text { Derivado da } \\
\text { bombesina }\end{array}$ & $\begin{array}{c}\text { Massa Molar do } \\
\text { Derivado } \\
\mathbf{( g / m o l )}\end{array}$ & $\begin{array}{c}\text { Pureza } \\
\text { Radioquímica }\end{array}$ & $\begin{array}{c}\text { Atividade } \\
\text { Específica } \\
\mathbf{( \% )}\end{array}$ & $\begin{array}{c}\text { Atividade } \\
\text { Específica }\end{array}$ \\
$\mathrm{BEFG}_{1^{-}}{ }^{177} \mathrm{Lu}$ & 1645,9 & $98,4 \pm 1,0$ & $4,5 \pm 0,1$ & $7,5 \pm 0,1$ \\
$\mathrm{BEFG}_{2^{-}}{ }^{177} \mathrm{Lu}$ & 1702,9 & $98,9 \pm 1,3$ & $4,6 \pm 0,1$ & $7,8 \pm 0,1$ \\
$\mathrm{BEFG}_{3^{-}}{ }^{177} \mathrm{Lu}$ & 1760,0 & $99,4 \pm 0,2$ & $4,6 \pm 0,1$ & $8,1 \pm 0,1$ \\
$\mathrm{BEFG}_{4^{-}}{ }^{177} \mathrm{Lu}$ & 1817,0 & $98,8 \pm 1,0$ & $4,6 \pm 0,1$ & $8,4 \pm 0,1$ \\
$\mathrm{BEFG}_{5^{-}}{ }^{177} \mathrm{Lu}$ & 1874,1 & $98,4 \pm 0,9$ & $4,5 \pm 0,1$ & $8,5 \pm 0,1$ \\
\hline
\end{tabular}

Os resultados da análise da radiomarcação por cromatografia em camada delgada foram confirmados pela cromatografia líquida de alta eficiência (CLAE). Os derivados foram eluídos em uma coluna de fase reversa $\mathrm{C}_{18}$, com um gradiente linear de 10 a $90 \%(\mathrm{v} / \mathrm{v})$ de TFA: $\mathrm{CH}_{3} \mathrm{CN}(1: 1000 \mathrm{v} / \mathrm{v})$ em TFA: $\mathrm{H}_{2} \mathrm{O}(1: 1000 \mathrm{v} / \mathrm{v})$ a um fluxo de 1,5 $\mathrm{mL} /$ minuto por 15 minutos. Nesse sistema, o lutécio não ligado (FIG. 20) foi facilmente separado dos peptídeos radiomarcados pela diferença entre seus tempos de retenção (TR). Os radiocromatogramas dos derivados radiomarcados (FIG. 21, 22, 23, 24 e 25) mostraram apenas uma pequena fração de ${ }^{177} \mathrm{LuCl}_{3}$ nas misturas de reação $(<2 \%)$, resultado da alta pureza radioquímica das marcações. 


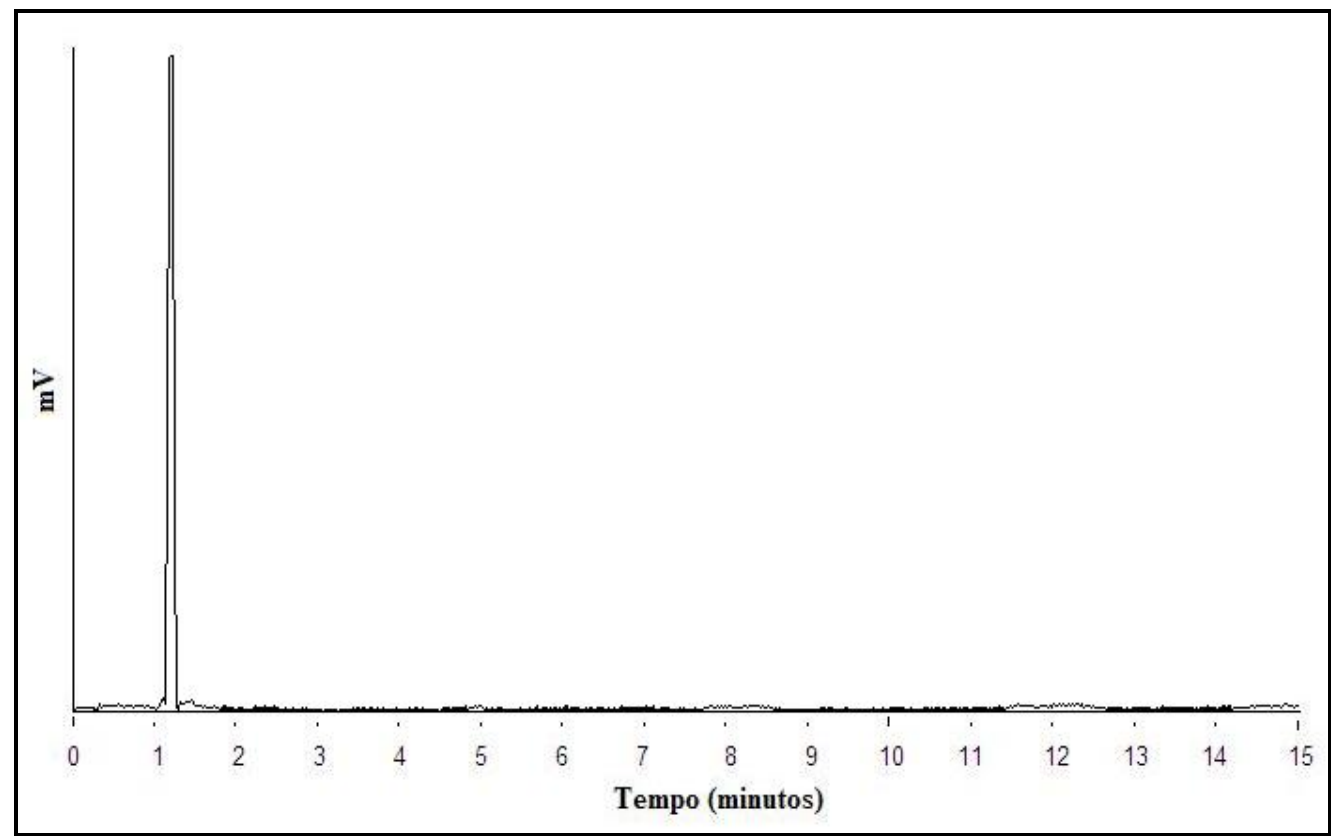

FIGURA 20 - Perfil de CLAE (radioativo) do ${ }^{177} \mathrm{LuCl}_{3}$, utilizando-se uma coluna $\mathrm{C}_{18}$, com um gradiente linear de 10 a 90\% de TFA: $\mathrm{CH}_{3} \mathrm{CN}(1: 1000 \mathrm{v} / \mathrm{v})$ em TFA: $\mathrm{H}_{2} \mathrm{O}(1: 1000 \mathrm{v} / \mathrm{v}) \mathrm{a}$ um fluxo de $1,5 \mathrm{~mL} /$ minuto por 15 minutos.

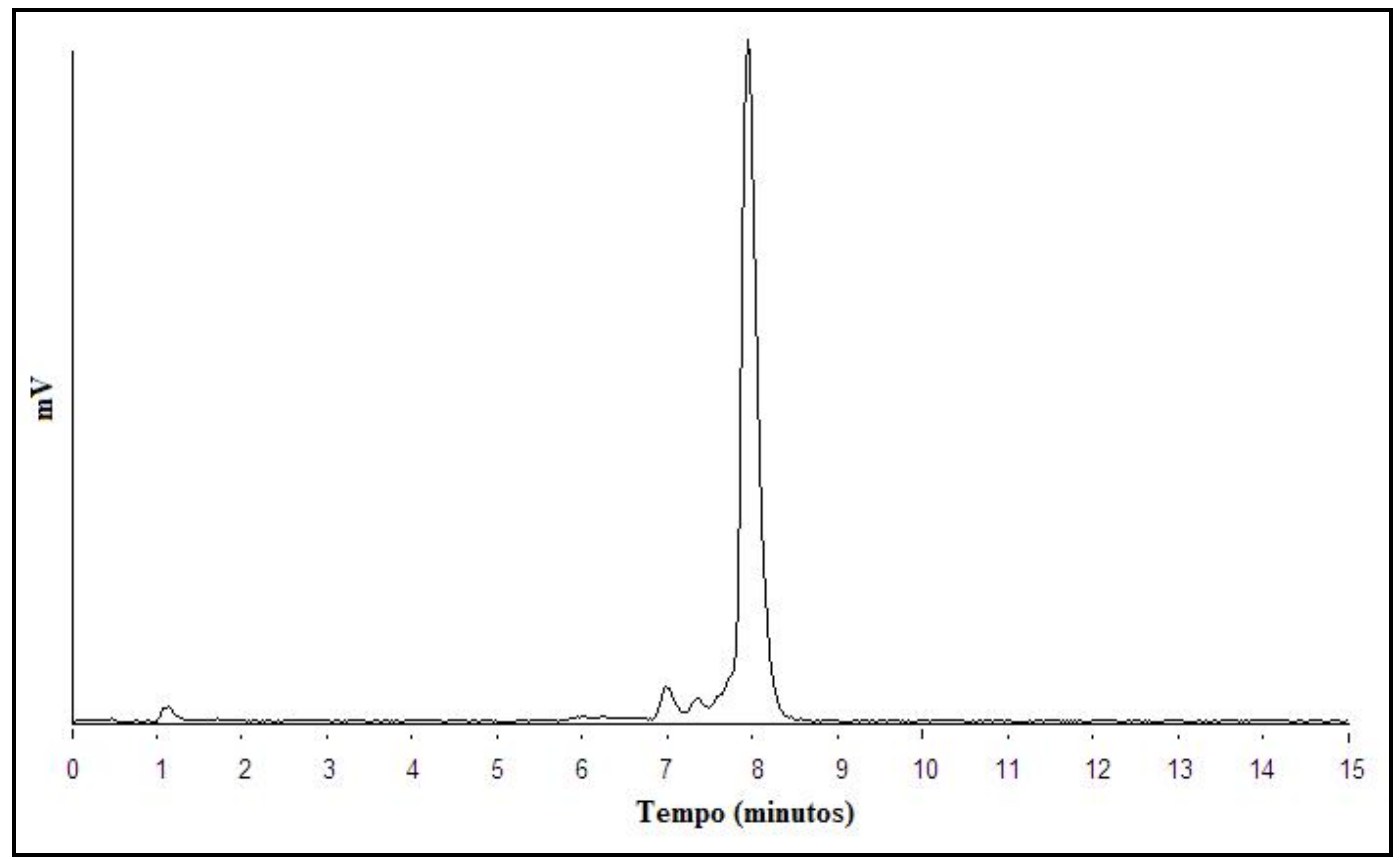

FIGURA 21 - Perfil de CLAE (radioativo) do $\mathrm{BEFG}_{1^{-}}{ }^{177} \mathrm{Lu}$, utilizando-se uma coluna $\mathrm{C}_{18}$, com um gradiente linear de 10 a $90 \%$ de TFA: $\mathrm{CH}_{3} \mathrm{CN}(1: 1000 \mathrm{v} / \mathrm{v})$ em TFA: $\mathrm{H}_{2} \mathrm{O}(1: 1000$ $\mathrm{v} / \mathrm{v}$ ) a um fluxo de $1,5 \mathrm{~mL} /$ minuto por 15 minutos. 


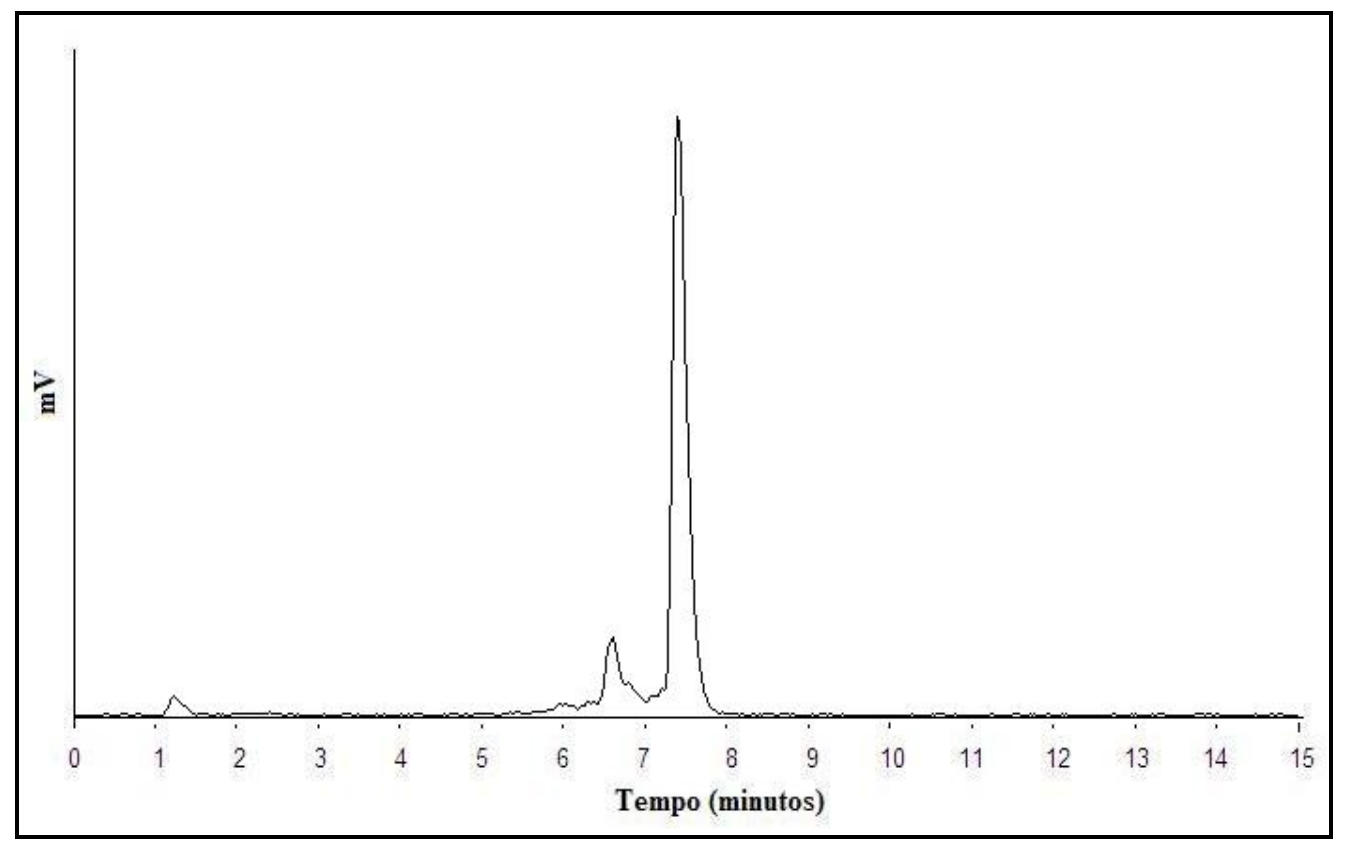

FIGURA 22 - Perfil de CLAE (radioativo) do $\mathrm{BEFG}_{2^{-}}{ }^{177} \mathrm{Lu}$, utilizando-se uma coluna $\mathrm{C}_{18 \text {, }}$ com um gradiente linear de 10 a 90\% de TFA: $\mathrm{CH}_{3} \mathrm{CN}(1: 1000 \mathrm{v} / \mathrm{v})$ em TFA: $\mathrm{H}_{2} \mathrm{O}(1: 1000$ $\mathrm{v} / \mathrm{v}$ ) a um fluxo de $1,5 \mathrm{~mL} /$ minuto por 15 minutos.

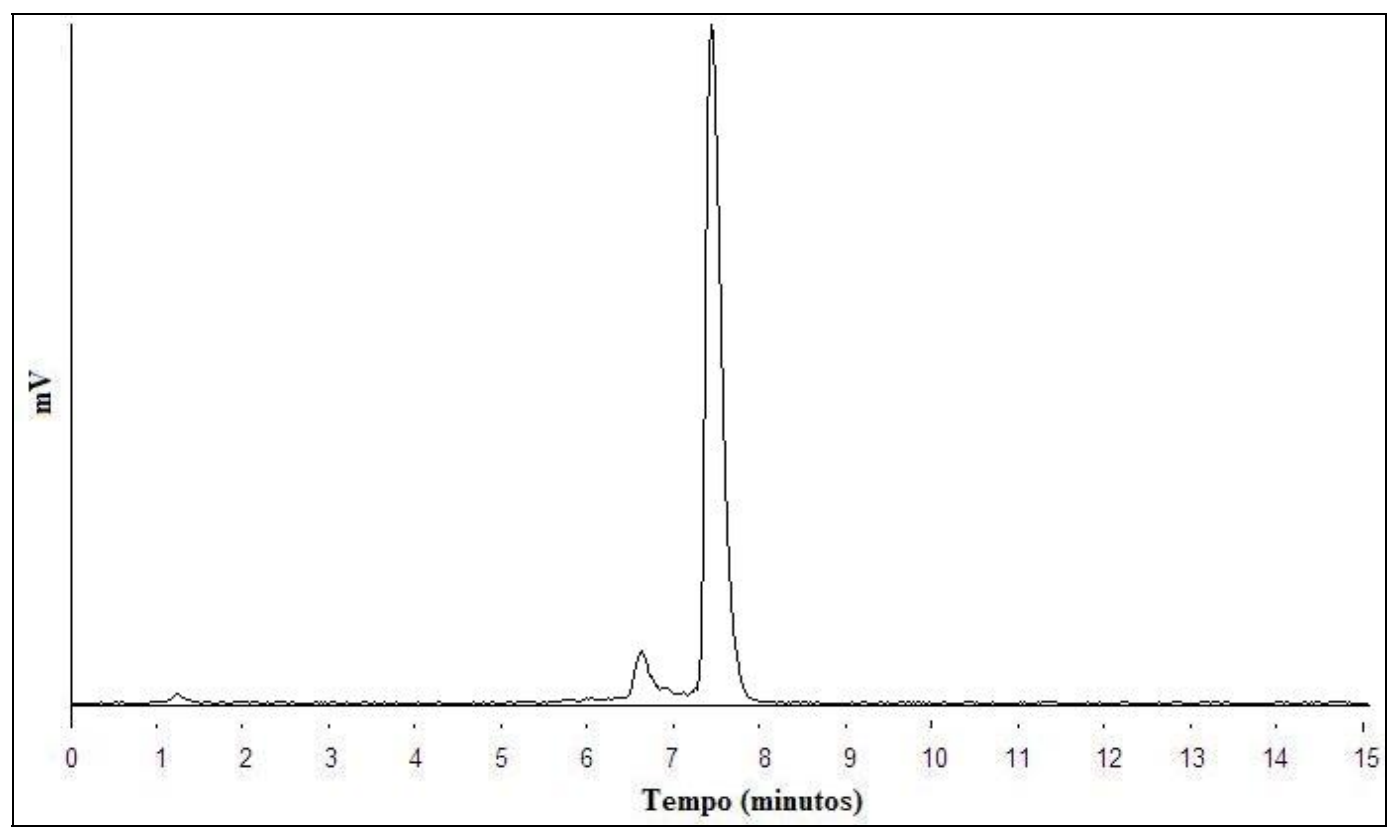

FIGURA 23 - Perfil de CLAE (radioativo) do $\mathrm{BEFG}_{3^{-}}{ }^{177} \mathrm{Lu}$, utilizando-se uma coluna $\mathrm{C}_{18}$, com um gradiente linear de 10 a 90\% de TFA: $\mathrm{CH}_{3} \mathrm{CN}(1: 1000 \mathrm{v} / \mathrm{v})$ em TFA: $\mathrm{H}_{2} \mathrm{O}(1: 1000$ $\mathrm{v} / \mathrm{v}$ ) a um fluxo de $1,5 \mathrm{~mL} /$ minuto por 15 minutos. 


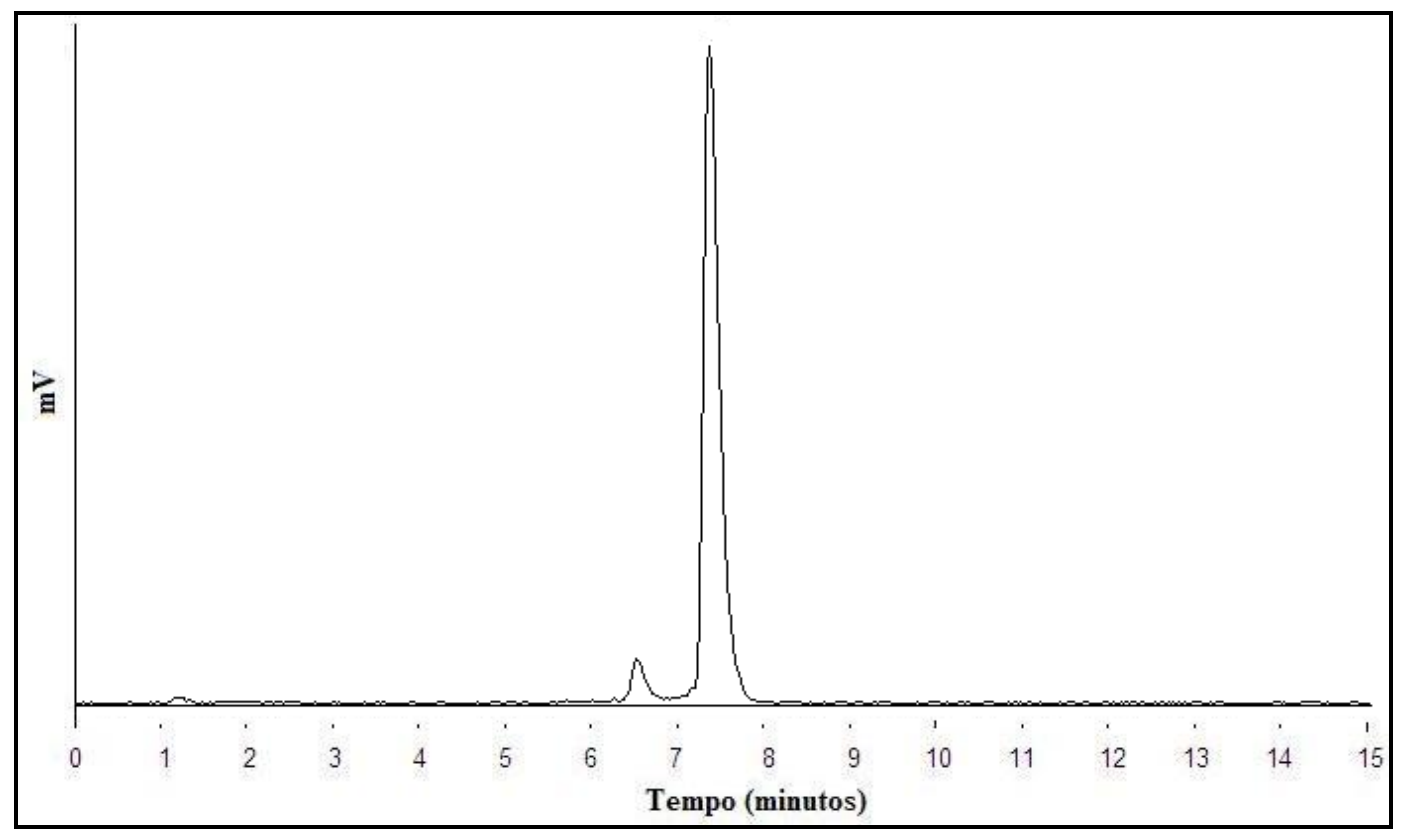

FIGURA 24 - Perfil de CLAE (radioativo) do $\mathrm{BEFG}_{4^{-}}{ }^{177} \mathrm{Lu}$, utilizando-se uma coluna $\mathrm{C}_{18}$, com um gradiente linear de 10 a 90\% de TFA: $\mathrm{CH}_{3} \mathrm{CN}(1: 1000 \mathrm{v} / \mathrm{v})$ em TFA: $\mathrm{H}_{2} \mathrm{O}(1: 1000$ $\mathrm{v} / \mathrm{v}$ ) a um fluxo de $1,5 \mathrm{~mL} /$ minuto por 15 minutos.

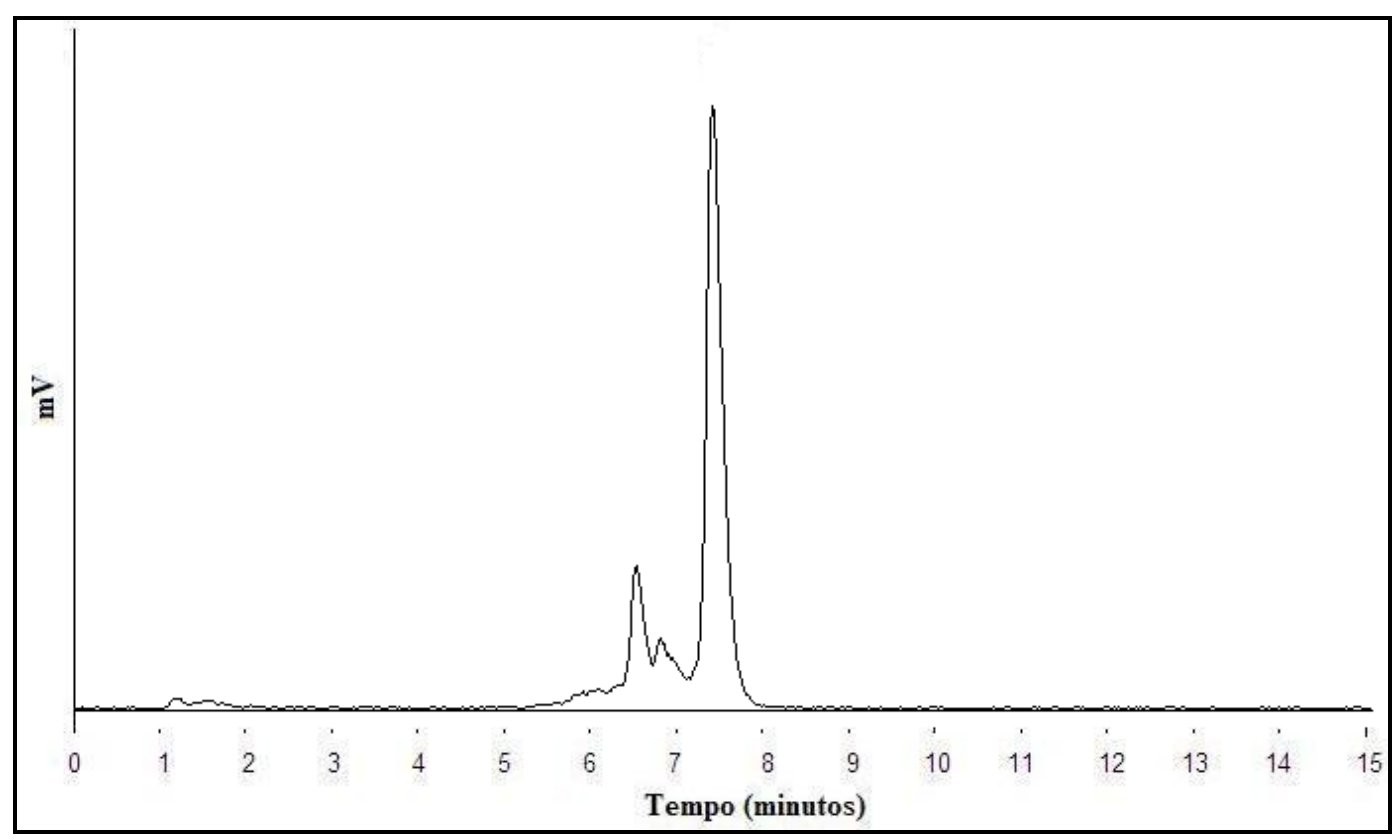

FIGURA 25 - Perfil de CLAE (radioativo) do $\mathrm{BEFG}_{5^{-}}{ }^{177} \mathrm{Lu}$, utilizando-se uma coluna $\mathrm{C}_{18}$, com um gradiente linear de 10 a $90 \%$ de TFA: $\mathrm{CH}_{3} \mathrm{CN}(1: 1000 \mathrm{v} / \mathrm{v})$ em TFA: $\mathrm{H}_{2} \mathrm{O}(1: 1000$ $\mathrm{v} / \mathrm{v}$ ) a um fluxo de $1,5 \mathrm{~mL} /$ minuto por 15 minutos. 
A análise por CLAE também revelou a existência de uma segunda espécie radioativa no esquema do cromatograma de todos os derivados (FIG. 21, 22, 23, 24 e 25), ausente no perfil em CLAE dos derivados não radiomarcados utilizando sistema de detecção UV a $280 \mathrm{~nm}$ (FIG. 26) e com tempo de retenção ligeiramente menor do que os peptídeos radiomarcados (TAB. 4, Pico 1).

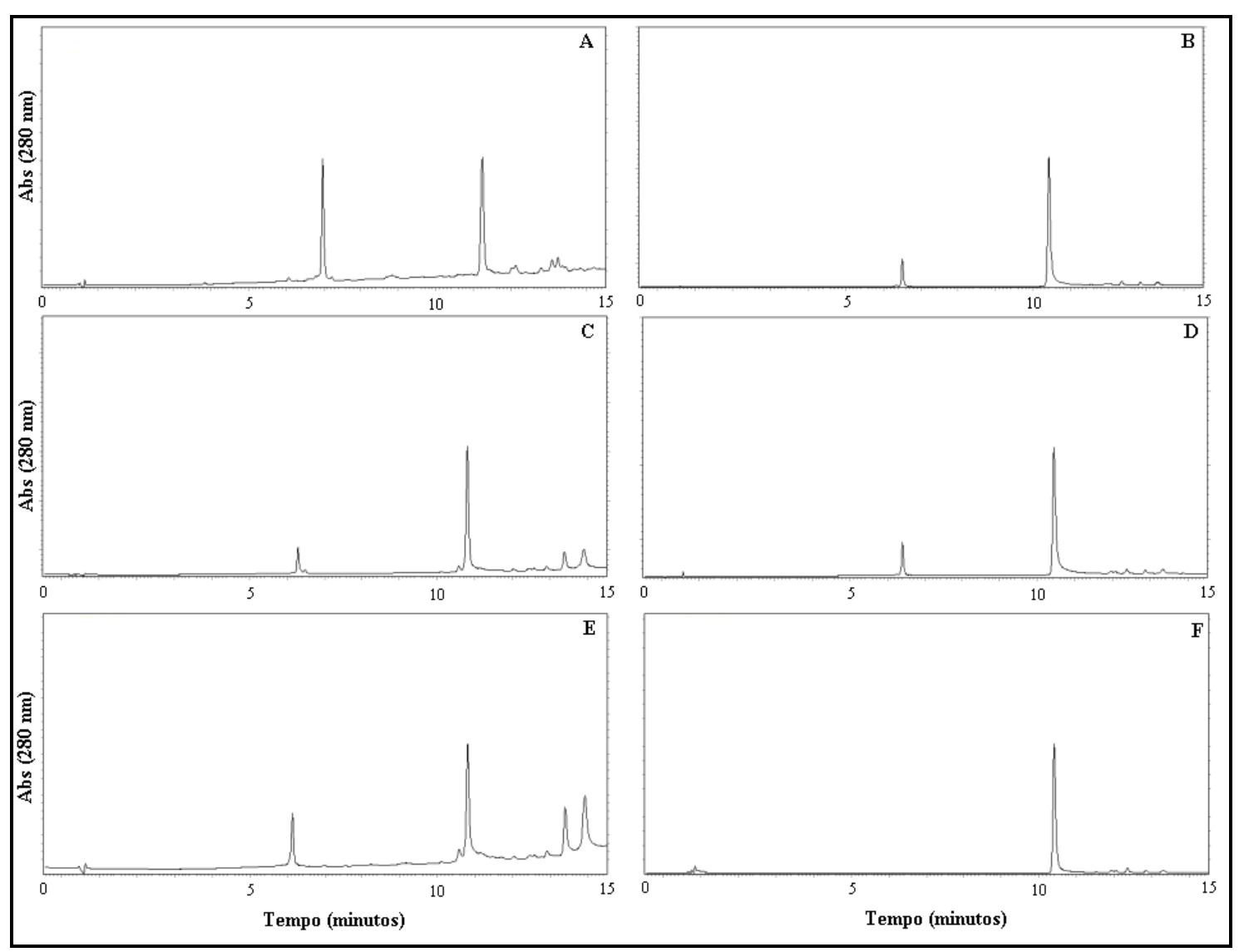

FIGURA 26 - Perfil de CLAE dos derivados da bombesina BEFG 1 (A), BEFG $(\mathrm{B})$, $\mathrm{BEFG}_{3}(\mathrm{C}), \mathrm{BEFG}_{4}(\mathrm{D}), \mathrm{BEFG}_{5}$ (E) e do veículo em que foram diluídos (F), utilizando-se uma coluna $\mathrm{C}_{18}$, com um gradiente linear de 10 a $90 \%$ de $\mathrm{TFA}: \mathrm{CH}_{3} \mathrm{CN}(1: 1000 \mathrm{v} / \mathrm{v}) \mathrm{em}$ TFA: $\mathrm{H}_{2} \mathrm{O}(1: 1000 \mathrm{v} / \mathrm{v})$ a um fluxo de $1,5 \mathrm{~mL} /$ minuto por 15 minutos e sistema de detecção UV.

Segundo a literatura consultada, a oxidação da metionina (Met) à metionina sulfóxido (Met-O) dá origem a uma espécie com tempo de retenção menor do que o peptídeo radiomarcado não oxidado (Chen et al., 2008). Essa forma oxidada já foi descrita como produto primário da degradação de outros derivados da bombesina, representando cerca de $10 \%$ da radioatividade total (Zhang et al, 2007; Chen et al, 2008) e pode ser resultante do processo de marcação em alta temperatura e $\mathrm{pH}$ ácido. Esse processo de oxidação pode ser evitado pela adição de um agente estabilizante à reação de marcação 
(Zhang et al, 2007; Chen et al, 2008) ou pela substituição deste aminoácido por um aminoácido sintético, como a norleucina (Maina et al., 2005). Dentre os agentes estabilizantes possíveis estão compostos naturais de selênio, tais como a selênio-metionina, a selênio-cisteína, e agentes redutores sulfurados, tais como o 2-mercaptoetanol, o ditiotreitol e o ácido 1-pirrolidinocarboditióico. Chen e colaboradores estudaram o efeito desses agentes estabilizantes sobre a formação de Met-O na reação de marcação do AMBA- $-{ }^{177} \mathrm{Lu}$ e mostraram que todos são efetivos para esse propósito.

Até o presente, se desconhece o efeito da presença da forma oxidada na mistura de radiomarcação sobre a biodistribuição e interação de derivados da bombesina com seus receptores in vivo e in vitro. Apesar da possibilidade de substituição do aminoácido sugerir que modificações na metionina não provocam alterações significativas nas propriedades biológicas dos análogos da bombesina, esse aminoácido compõe a porção C-terminal da cadeia de aminoácidos da bombesina, homóloga ao peptídeo liberador de gastrina e à neuromedina B e considerada essencial para a sua interação com os receptores. Portanto, outros estudos devem ser realizados para analisar o efeito da adição dos agentes estabilizantes sobre a formação de Met-O nos derivados do presente trabalho e os radiofármacos produzidos na presença do estabilizante deverão comparados com os produzidos na ausência de estabilizante quanto ao seu comportamento in vivo.

TABELA 4 - Tempos de retenção do cloreto de lutécio-177 e dos derivados da bombesina não radiomarcados e radiomarcados em CLAE $(n=3)$. Os picos 1 e 2 correspondem à primeira e segunda espécies radioativas, respectivamente.

Espécie Química

${ }^{177} \mathrm{LuCl}_{3}$

Derivado da bombesina

Não radiomarcado

Tempo de Retenção em CLAE (minutos)

\begin{tabular}{|c|c|c|c|}
\hline & & Pico 1 & Pico 2 \\
\hline $\mathrm{BEFG}_{1}$ & $7,3 \pm 0,1$ & $6,9 \pm 0,2$ & $7,7 \pm 0,3$ \\
\hline $\mathrm{BEFG}_{2}$ & $6,9 \pm 0,1$ & $6,8 \pm 0,1$ & $7,4 \pm 0,1$ \\
\hline $\mathrm{BEFG}_{3}$ & $6,9 \pm 0,3$ & $6,6 \pm 0,1$ & $7,3 \pm 0,1$ \\
\hline $\mathrm{BEFG}_{4}$ & $6,8 \pm 0,1$ & $6,5 \pm 0,1$ & $7,2 \pm 0,1$ \\
\hline $\mathrm{BEFG}_{5}$ & $6,6 \pm 0,1$ & $6,4 \pm 0,1$ & $7,2 \pm 0,1$ \\
\hline
\end{tabular}


Os tempos de retenção dos derivados da bombesina, mostrados na TAB. 4, podem ser utilizados para análise comparativa de sua lipossolubilidade. Na cromatografia em fase reversa, considerando-se o mesmo gradiente de solventes e a mesma fase estacionária (coluna $\mathrm{C}_{18}$ ), a espécie mais lipossolúvel é aquela que apresenta maior tempo de retenção. Pelos resultados obtidos, verificou-se que o aumento no tamanho do espaçador reduz discretamente a lipossolubilidade dos derivados da bombesina, sendo o $\mathrm{BEFG}_{1} \mathrm{o}$ derivado mais lipossolúvel e o $\mathrm{BEFG}_{5}$ o menos lipossolúvel. Apesar do aumento no tamanho do espaçador representar um aumento na cadeia carbônica dos derivados, a redução observada em sua lipossolubidade indica que a adição do aminoácido glicina à sequência de aminoácidos do espaçador aumenta sua polaridade.

Os aminoácidos individuais são classificados de acordo com vários critérios, dos quais a natureza polar ou apolar da cadeia lateral é particularmente importante. A glicina (Gly, FIG. 27) é o aminoácido mais simples e sua cadeia lateral é composta de apenas um átomo de hidrogênio. Em alguns esquemas de classificação essa cadeia lateral é considerada do tipo polar eletricamente neutra, porque lhe falta uma cadeia lateral apolar e, em outros, como apolar, já que a glicina não possui cadeia lateral polar. Já a fenilalanina (Phe, FIG. 28) apresenta cadeia lateral apolar, composta por um hidrocarboneto aromático em substituição ao hidrogênio da glicina (Campbell, 2001). O aumento no número de aminoácidos glicina ligados a um aminoácido fenilalanina, apolar, reduziu discretamente a lipossolubilidade dos derivados da bombesina, sugerindo a cadeia lateral da glicina confere caráter polar aos espaçadores dos derivados.

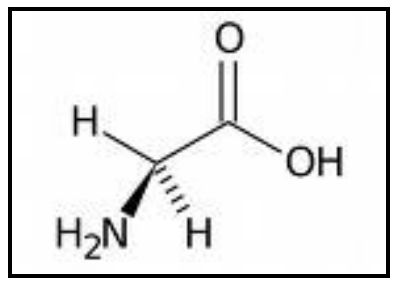

FIGURA 27 - Estrutura do aminoácido glicina (Aminoácidos, 2009).

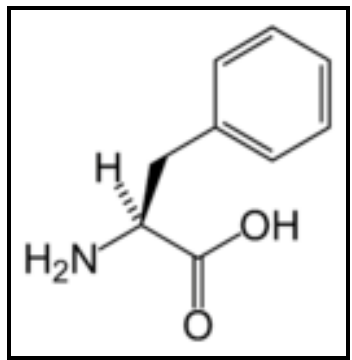

FIGURA 28 - Estrutura do aminoácido fenilalanina (Aminoácidos, 2009). 


\subsection{Análise da estabilidade dos derivados radiomarcados}

A estabilidade dos derivados radiomarcados foi analisada após armazenamento à $2-8^{\circ} \mathrm{C}$ em geladeira por até 168 horas e à $37^{\circ} \mathrm{C}$ em soro humano por até 24 horas. Os resultados da análise de estabilidade dos derivados estudados à $2-8^{\circ} \mathrm{C}$ são mostrados na TAB. 5. A pureza radioquímica foi determinada por cromatografia em camada delgada em sílica gel 60 (ITLC-SG). Todos os derivados apresentaram alta estabilidade nessa temperatura, na qual a pureza radioquímica foi em geral maior ou igual a 95\% por até 96 horas (quatro dias). A pureza radioquímica maior do que $95 \%$ pode ser estabelecida como critério de aceitação para a aplicação clínica, tendo em vista a pequena porcentagem de radioisótopo livre. Além disso, não foi verificada relação aparente entre a estrutura dos derivados da bombesina estudados e sua estabilidade à $2-8^{\circ} \mathrm{C}$.

TABELA 5 - Estabilidade dos derivados radiomarcados com cloreto de lutécio-177 (ITLC-SG) após armazenamento à $2-8^{\circ} \mathrm{C}$ por diferentes tempos $(\mathrm{n}=3)$. Os dados estão expressos em porcentagem de pureza radioquímica.

\begin{tabular}{|c|c|c|c|c|c|c|}
\hline \multirow[b]{2}{*}{$\begin{array}{l}\text { Derivado da } \\
\text { bombesina }\end{array}$} & \multicolumn{6}{|c|}{ Pureza Radioquímica (\%) } \\
\hline & Imediato & 24 horas & 48 horas & 72 horas & 96 horas & 168 horas \\
\hline $\mathrm{BEFG}_{1^{-}}{ }^{177} \mathrm{Lu}$ & $99,7 \pm 0,1$ & $98,8 \pm 0,1$ & $98,2 \pm 0,4$ & $96,4 \pm 0,1$ & $97,4 \pm 0,5$ & $93,8 \pm 0,1$ \\
\hline $\mathrm{BEFG}_{2^{-}}{ }^{177} \mathrm{Lu}$ & $99,4 \pm 0,1$ & $98,3 \pm 0,2$ & $97,8 \pm 0,6$ & $96,3 \pm 0,1$ & $96,9 \pm 0,1$ & $94,3 \pm 0,1$ \\
\hline $\mathrm{BEFG}_{3^{-}}{ }^{177} \mathrm{Lu}$ & $99,5 \pm 0,1$ & $97,5 \pm 0,1$ & $97,2 \pm 0,1$ & $96,6 \pm 0,8$ & $95,8 \pm 0,2$ & $92,6 \pm 0,3$ \\
\hline $\mathrm{BEFG}_{4^{-}}{ }^{177} \mathrm{Lu}$ & $98,3 \pm 0,6$ & $97,8 \pm 0,1$ & $96,4 \pm 0,1$ & $94,9 \pm 0,2$ & $94,8 \pm 0,2$ & $89,5 \pm 1,4$ \\
\hline $\mathrm{BEFG}_{5^{-}}{ }^{177} \mathrm{Lu}$ & $98,9 \pm 0,5$ & $98,1 \pm 0,8$ & $96,2 \pm 1,0$ & $95,6 \pm 0,3$ & $94,1 \pm 1,8$ & $91,4 \pm 1,1$ \\
\hline
\end{tabular}

Para análise da estabilidade em soro humano, os derivados radiomarcados foram diluídos em soro humano fresco e os perfis cromatográficos em ITLC-SG foram examinados imediatamente e após 1,4 e 24 horas de incubação à $37^{\circ} \mathrm{C}$. Os perfis obtidos foram então comparados ao do ${ }^{177} \mathrm{LuCl}_{3}$ incubado nas mesmas condições e os resultados são apresentados na FIG. 29. Pode-se observar que os derivados radiomarcados provavelmente sofrem metabolismo pelas ações das enzimas do soro, dando origem a espécies que migram no sistema cromatográfico utilizado. Essas espécies podem ser originadas da quebra na cadeia de aminoácidos dos derivados da bombesina e não apenas 
da descomplexação do ${ }^{177} \mathrm{Lu}$, uma vez que os produtos de degradação metabólica migram com $\mathrm{R}_{\mathrm{f}}$ diferente do radiolantanídeo não ligado. Além disso, a alteração nas características mostradas cromatograficamente não corresponde à ligação do ${ }^{177} \mathrm{Lu}$ descomplexado às proteínas do soro, já que o perfil dessa espécie não se altera com o decorrer do tempo de incubação.

Zhang e colaboradores (2004) identificaram três metabólitos originários do análogo da bombesina BZH1 - GABA-[D-Tyr ${ }^{6}, \beta-\mathrm{Ala}^{11}$, Thi ${ }^{13}$; Nle $\left.{ }^{14}\right]-B B N(6-14)-D T P A-$ radiomarcado com ${ }^{111}$ In após sua incubação em soro humano. Esses metabólitos eram produtos da clivagem entre os aminoácidos $\beta$-Ala ${ }^{11}$ e His $^{12}$ e da posterior decomposição do produto radioativo em DTPA- ${ }^{111}$ In e em outro produto radioativo decorrente da clivagem entre os aminoácidos Gln e Trp. Os metabólitos originários do análogo BZH2- ${ }^{111}$ In GABA-[D-Tyr ${ }^{6}, \beta-$ Ala $^{11}$, Thi $^{13}$; Nle ${ }^{14}$ ]-BBN(6-14)-DOTA- ${ }^{111} \mathrm{In}$ - incubado nas mesmas condições eram semelhantes, indicando que não há influência do agente quelante sobre a atividade enzimática in vitro. Apesar da ligação $\beta$-Ala-His não ser encontrada nos derivados estudados neste trabalho, a ligação Gln-Trp faz parte da sequência da bombesina do aminoácido 6 ao aminoácido 14 e está presente em todos os derivados estudados, podendo ser um dos pontos da clivagem enzimática observada in vitro. Esses prováveis produtos de clivagem são possivelmente os responsáveis pela alteração tempo-dependente nos perfis cromatográficos dos derivados estudados após a incubação em soro humano, mostrados na FIG. 29. Outro ponto de clivagem pode ser a ligação Phe-DOTA- ${ }^{177}$ Lu, dando origem ao produto DOTA- ${ }^{177} \mathrm{Lu}$, mas essa espécie provavelmente não é a responsável pela alteração nos perfis cromatográficos, visto que migraria juntamente com a frente de solvente, conforme observado para o ${ }^{177} \mathrm{LuCl}_{3}$ (Breeman et al., 2002).

O deslocamento das espécies radioativas no sistema cromatográfico, além de indicar metabolismo dos derivados da bombesina pela ação das enzimas do soro, sugere que os metabólitos produzidos são mais polares em relação aos derivados íntegros, visto que o sistema cromatográfico utilizado separa as espécies também por polaridade. 


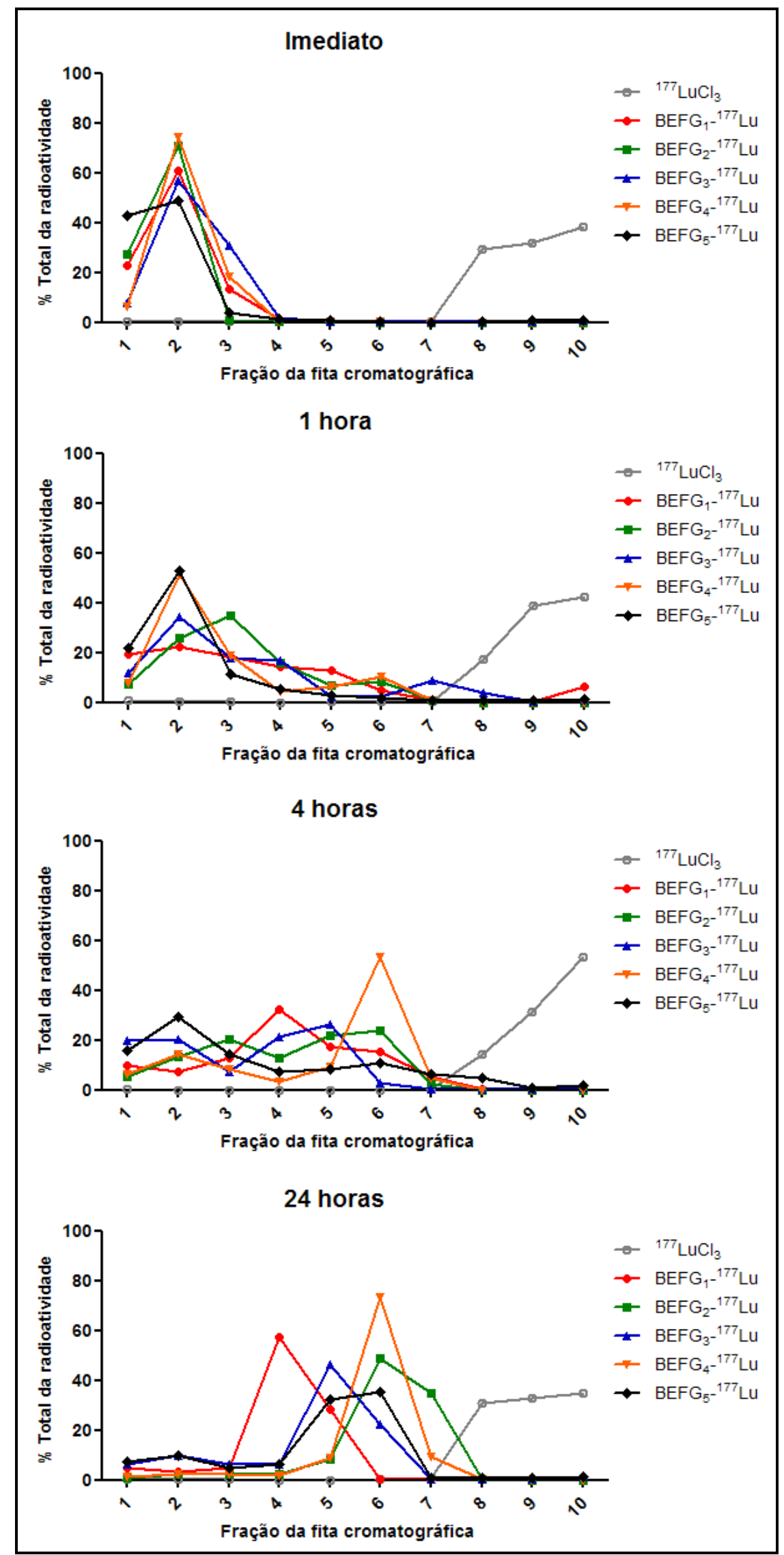

FIGURA 29 - Perfil cromatográfico dos derivados da bombesina radiomarcados com ${ }^{177} \mathrm{Lu}$ e do radiolantanídeo não ligado em ITLC-SG após incubação em soro humano à $37^{\circ} \mathrm{C}$. 
Os perfis cromatográficos mostrados anteriormente foram utilizados para calcular a porcentagem dos derivados radiomarcados e do ${ }^{177} \mathrm{LuCl}_{3}$ íntegros após a incubação em soro em cada tempo. Os resultados são mostrados na TAB. 6. O metabolismo dos derivados é tempo-dependente e, apesar de após 24 horas apenas uma pequena porcentagem deles ainda permanecer intacta, a estabilidade desses peptídeos é maior do que a da bombesina nativa, a qual apresenta meia-vida de apenas 30 minutos em soro in vitro (Garayoa et al., 2007). A estabilidade dos derivados pode ser aumentada pela substituição dos aminoácidos $\mathrm{Leu}^{13} \mathrm{e} / \mathrm{ou} \mathrm{Met}^{14}$ por aminoácidos artificiais, tais como ciclohexilalanina (Cha) ou norleucina (Nle), respectivamente, conforme já descrito por Garayoa e colaboradores (2007).

TABELA 6 - Estabilidade metabólica dos derivados da bombesina radiomarcados em soro humano à $37^{\circ} \mathrm{C}(\mathrm{n}=4)$.

\section{Porcentagem de espécie radioquímica com $R_{\mathrm{f}}$ 0,1-0,3 após} incubação em soro humano a $37^{\circ} \mathrm{C}$

\begin{tabular}{ccccc}
\hline Espécie química & Imediato & 1 hora & 4 horas & 24 horas \\
$\mathrm{BEFG}_{1^{-}}{ }^{177} \mathrm{Lu}$ & $97,2 \pm 0,7$ & $60,3 \pm 1,9$ & $40,3 \pm 2,6$ & $12,8 \pm 1,2$ \\
$\mathrm{BEFG}_{2}{ }^{177} \mathrm{Lu}$ & $99,2 \pm 0,1$ & $77,9 \pm 5,3$ & $39,0 \pm 9,0$ & $7,4 \pm 1,5$ \\
$\mathrm{BEFG}_{3-}{ }^{177} \mathrm{Lu}$ & $95,4 \pm 0,3$ & $64,0 \pm 6,3$ & $47,5 \pm 3,0$ & $22,2 \pm 0,6$ \\
$\mathrm{BEFG}_{4^{-}}{ }^{177} \mathrm{Lu}$ & $99,0 \pm 0,3$ & $82,5 \pm 1,7$ & $50,0 \pm 0,7$ & $7,7 \pm 1,1$ \\
$\mathrm{BEFG}_{5^{-}}{ }^{177} \mathrm{Lu}$ & $95,5 \pm 0,3$ & $86,1 \pm 2,4$ & $64,3 \pm 4,2$ & $21,8 \pm 0,8$ \\
\hline
\end{tabular}

O ensaio de estabilidade in vitro em soro humano orienta sobre o grau da integridade do produto in vivo, o qual está diretamente ligado ao poder metabólico e funcional do mesmo. A maior estabilidade dos derivados radiomarcados no soro pode refletir uma maior quantidade de radiofármaco intacto presente na área do tumor, aumentando a probabilidade de ligação à superfície das células tumorais (Garayoa et al., 2007). A análise dos dados da TAB. 6 permite o estabelecimento de uma relação entre a estrutura dos derivados da bombesina e sua estabilidade em soro humano. A adição de aminoácidos glicina ao espaçador aumentou sua estabilidade in vitro em soro humano até após 4 horas de incubação, sendo o $\mathrm{BEFG}_{1^{-}}{ }^{177} \mathrm{Lu}$ o derivado menos estável e o $\mathrm{BEFG}_{5^{-}}$ ${ }^{177} \mathrm{Lu}$ o mais estável na condição estudada. Essa relação não foi observada quando o tempo 
de incubação aumentou para 24 horas, provavelmente devido à reduzida proporção dos derivados íntegros após esse tempo.

\subsection{Determinação do coeficiente de partição experimental dos derivados radiomarcados $(\mathrm{CP})$}

Os coeficientes de partição experimentais dos derivados radiomarcados são mostrados na TAB. 7. Todos os derivados radiomarcados apresentam baixa lipossolubilidade e, confirmando a tendência anteriormente mostrada pela análise em CLAE, o aumento do espaçador reduz discretamente sua lipossolubilidade, apesar do aumento na cadeia carbônica.

TABELA 7 - Coeficiente de partição (CP) óleo:água (n-octanol:água) dos derivados da bombesina radiomarcados com ${ }^{177} \mathrm{Lu}(\mathrm{n}=5)$.

\section{Coeficiente de Partição Experimental}

\begin{tabular}{cccccc}
\hline Derivado & BEFG $_{1^{-}}{ }^{177} \mathbf{L u}$ & BEFG $_{2}{ }^{-177}$ Lu & BEFG $_{3^{-}}{ }^{177} \mathbf{L u}$ & BEFG $_{4^{-}}{ }^{177} \mathbf{L u}$ & BEFG $_{5^{-}}{ }^{177} \mathbf{L u}$ \\
$\mathrm{CP}$ & $-2,87 \pm 0,1$ & $-2,95 \pm 0,1$ & $-3,04 \pm 0,2$ & $-3,06 \pm 0,1$ & $-3,09 \pm 0,1$ \\
\hline
\end{tabular}

\subsection{Estudos in vivo}

\subsubsection{Estudos de biodistribuição em camundongos Balb-c sadios}

Os resultados dos estudos de biodistribuição do $\mathrm{BEFG}_{1^{-}}{ }^{177} \mathrm{Lu}, \mathrm{BEFG}_{2^{-}}{ }^{177} \mathrm{Lu}$, $\mathrm{BEFG}_{3^{-}}{ }^{177} \mathrm{Lu}, \mathrm{BEFG}_{4}{ }^{-}{ }^{177} \mathrm{Lu}_{\mathrm{e}} \mathrm{BEFG}_{5^{-}}{ }^{177} \mathrm{Lu}$ podem ser visualizados nas TAB. 8, 9, 10, $11 \mathrm{e}$ 12, respectivamente. Os dados estão expressos em porcentagem de atividade administrada em função da atividade captada pelo tecido (\% $\mathrm{AI})$ ou por grama de tecido $(\% \mathrm{AI} / \mathrm{g})$, com exceção da próstata, para a qual não há cálculo de \% AI/g devido ao seu baixo peso. 
TABELA 8 - Biodistribuição do derivado da bombesina BEFG $_{1}$ radiomarcado com lutécio-177 (0,185 MBq) em camundongos Balb-c machos sadios ( $\mathrm{n}=5)$.

\begin{tabular}{|c|c|c|c|c|c|c|}
\hline Peptídeo & \multicolumn{6}{|c|}{ BEFG $_{1^{-}}{ }^{177} \mathbf{L u}$} \\
\hline Tempo após & \multicolumn{2}{|c|}{1 hora } & \multicolumn{2}{|c|}{4 horas } & \multicolumn{2}{|c|}{24 horas } \\
\hline $\begin{array}{c}\text { Unidade de } \\
\text { medida }\end{array}$ & $\% \mathrm{AI}$ & $\% \mathrm{AI} / \mathrm{g}$ & $\% \mathrm{AI}$ & $\% \mathrm{AI} / \mathrm{g}$ & $\% \mathrm{AI}$ & $\% \mathrm{AI} / \mathrm{g}$ \\
\hline Próstata & $0,01 \pm 0,01$ & - & $0,01 \pm 0,01$ & - & 0,00 & - \\
\hline Coração & $0,02 \pm 0,01$ & $0,16 \pm 0,06$ & 0,00 & $0,03 \pm 0,01$ & 0,00 & $0,02 \pm 0$ \\
\hline Pulmões & $0,08 \pm 0,03$ & $0,3 \pm 0,14$ & $0,01 \pm 0,01$ & $0,07 \pm 0,01$ & $0,01 \pm 0,01$ & $0,09 \pm 0,08$ \\
\hline Pâncreas & $0,08 \pm 0,07$ & $0,16 \pm 0,07$ & $0,01 \pm 0,01$ & $0,04 \pm 0,01$ & 0,00 & $0,03 \pm 0,01$ \\
\hline Baço & $0,03 \pm 0,01$ & $0,16 \pm 0,04$ & $0,01 \pm 0,01$ & $0,06 \pm 0,01$ & $0,01 \pm 0,01$ & $0,07 \pm 0,01$ \\
\hline Estômago ${ }^{*}$ & $0,05 \pm 0,02$ & $0,25 \pm 0,1$ & $0,05 \pm 0,02$ & $0,12 \pm 0,05$ & $0,01 \pm 0,01$ & $0,04 \pm 0,02$ \\
\hline Fígado & $0,43 \pm 0,04$ & $0,33 \pm 0,08$ & $0,16 \pm 0,02$ & $0,12 \pm 0,01$ & $0,12 \pm 0,06$ & $0,1 \pm 0,06$ \\
\hline Rins & $1,37 \pm 0,29$ & $3,63 \pm 1,04$ & $0,95 \pm 0,09$ & $2,46 \pm 0,35$ & $0,47 \pm 0,08$ & $1,31 \pm 0,22$ \\
\hline Intestinos $^{* *}$ & $0,71 \pm 0,28$ & $0,32 \pm 0,12$ & $0,56 \pm 0,16$ & $0,28 \pm 0,14$ & $0,19 \pm 0,07$ & $0,08 \pm 0,03$ \\
\hline Músculo & $1,49 \pm 0,32$ & $0,14 \pm 0,04$ & $0,28 \pm 0,04$ & $0,05 \pm 0,03$ & $0,1 \pm 0,04$ & $0,01 \pm 0,01$ \\
\hline Esquelético & & & & & & \\
\hline Osso & $1,43 \pm 0,34$ & $0,45 \pm 0,14$ & $0,47 \pm 0,1$ & $0,17 \pm 0,04$ & $1,15 \pm 0,8$ & $0,36 \pm 0,18$ \\
\hline Cérebro & $0,03 \pm 0,01$ & $0,09 \pm 0,03$ & 0,00 & $0,01 \pm 0,01$ & 0,00 & 0,00 \\
\hline Cerebelo & $0,01 \pm 0,01$ & $0,13 \pm 0,01$ & 0,00 & $0,01 \pm 0,01$ & 0,00 & $0,01 \pm 0,01$ \\
\hline
\end{tabular}

Estômago vazio. ${ }^{* *}$ Intestinos com conteúdo. 
TABELA 9 - Biodistribuição do derivado da bombesina $\mathrm{BEFG}_{2}$ radiomarcado com lutécio-177 (0,185 MBq) em camundongos Balb-c machos sadios ( $\mathrm{n}=5)$.

\begin{tabular}{|c|c|c|c|c|c|c|}
\hline Peptídeo & \multicolumn{6}{|c|}{ BEFG $_{2^{-}}{ }^{177} \mathbf{L u}$} \\
\hline Tempo após & \multicolumn{2}{|c|}{1 hora } & \multicolumn{2}{|c|}{4 horas } & \multicolumn{2}{|c|}{24 horas } \\
\hline $\begin{array}{l}\text { Unidade de } \\
\text { medida }\end{array}$ & $\% A I$ & $\% \mathrm{AI} / \mathrm{g}$ & $\% A I$ & $\% \mathrm{AI} / \mathrm{g}$ & $\% A I$ & $\% \mathrm{AI} / \mathrm{g}$ \\
\hline Próstata & $0,01 \pm 0,01$ & - & $0,01 \pm 0,01$ & - & 0,00 & - \\
\hline Coração & $0,02 \pm 0,01$ & $0,16 \pm 0,03$ & $0,01 \pm 0,01$ & $0,04 \pm 0,01$ & $0,01 \pm 0,01$ & $0,02 \pm 0,01$ \\
\hline Pulmões & $0,06 \pm 0,01$ & $0,29 \pm 0,05$ & $0,01 \pm 0,01$ & $0,09 \pm 0,01$ & $0,01 \pm 0,01$ & $0,04 \pm 0,01$ \\
\hline Pâncreas & $0,03 \pm 0,01$ & $0,11 \pm 0,03$ & $0,01 \pm 0,01$ & $0,03 \pm 0,01$ & $0,01 \pm 0,01$ & $0,02 \pm 0,01$ \\
\hline Baço & $0,01 \pm 0,01$ & $0,09 \pm 0,01$ & $0,01 \pm 0,01$ & $0,08 \pm 0,02$ & $0,01 \pm 0,01$ & $0,04 \pm 0,01$ \\
\hline Estômago* & $0,07 \pm 0,02$ & $0,26 \pm 0,07$ & $0,01 \pm 0,01$ & $0,04 \pm 0,01$ & $0,02 \pm 0,01$ & $0,07 \pm 0,05$ \\
\hline Fígado & $0,27 \pm 0,05$ & $0,21 \pm 0,05$ & $0,14 \pm 0,02$ & $0,11 \pm 0,01$ & $0,08 \pm 0,01$ & $0,05 \pm 0,01$ \\
\hline Rins & $0,98 \pm 0,11$ & $2,16 \pm 0,28$ & $0,69 \pm 0,16$ & $1,59 \pm 0,17$ & $0,34 \pm 0,04$ & $0,78 \pm 0,16$ \\
\hline Intestinos $^{* *}$ & $0,71 \pm 0,21$ & $0,32 \pm 0,10$ & $0,41 \pm 0,20$ & $0,17 \pm 0,10$ & $0,51 \pm 0,20$ & $0,20 \pm 0,11$ \\
\hline Músculo & $1,38 \pm 0,71$ & $0,12 \pm 0,07$ & $0,43 \pm 0,25$ & $0,03 \pm 0,01$ & $0,16 \pm 0,10$ & $0,01 \pm 0,01$ \\
\hline Esquelético & & & & & & \\
\hline Osso & $1,16 \pm 0,30$ & $0,36 \pm 0,11$ & $0,95 \pm 0,60$ & $0,30 \pm 0,15$ & $0,73 \pm 0,13$ & $0,18 \pm 0,11$ \\
\hline Cérebro & $0,01 \pm 0,01$ & $0,03 \pm 0,01$ & 0,00 & 0,00 & 0,00 & 0,00 \\
\hline Cerebelo & $0,01 \pm 0,01$ & $0,06 \pm 0,02$ & 0,00 & 0,00 & 0,00 & 0,00 \\
\hline
\end{tabular}

Estômago vazio. ${ }^{* *}$ Intestinos com conteúdo. 
TABELA 10 - Biodistribuição do derivado da bombesina $\mathrm{BEFG}_{3}$ radiomarcado com lutécio-177 (0,185 MBq) em camundongos Balb-c machos sadios $(\mathrm{n}=5)$.

\begin{tabular}{|c|c|c|c|c|c|c|}
\hline Peptídeo & \multicolumn{6}{|c|}{$\mathrm{BEFG}_{3^{-}}{ }^{177} \mathbf{L u}$} \\
\hline Tempo após & \multicolumn{2}{|c|}{1 hora } & \multicolumn{2}{|c|}{4 horas } & \multicolumn{2}{|c|}{24 horas } \\
\hline $\begin{array}{c}\text { Unidade de } \\
\text { medida }\end{array}$ & $\%$ AI & $\% \mathrm{AI} / \mathrm{g}$ & $\%$ AI & $\% \mathrm{AI} / \mathrm{g}$ & $\% \mathrm{AI}$ & $\% \mathrm{AI} / \mathrm{g}$ \\
\hline Próstata & $0,09 \pm 0,03$ & - & $0,02 \pm 0,01$ & - & 0,00 & - \\
\hline Coração & $0,01 \pm 0,01$ & $0,08 \pm 0,03$ & $0,01 \pm 0,01$ & $0,06 \pm 0,02$ & $0,01 \pm 0,01$ & $0,05 \pm 0,03$ \\
\hline Pulmões & $0,05 \pm 0,02$ & $0,19 \pm 0,05$ & $0,02 \pm 0,01$ & $0,08 \pm 0,03$ & $0,01 \pm 0,01$ & $0,05 \pm 0,01$ \\
\hline Pâncreas & $0,01 \pm 0,01$ & $0,08 \pm 0,02$ & $0,01 \pm 0,01$ & $0,05 \pm 0,01$ & $0,01 \pm 0,01$ & $0,04 \pm 0,01$ \\
\hline Baço & $0,01 \pm 0,01$ & $0,09 \pm 0,02$ & $0,01 \pm 0,01$ & $0,1 \pm 0,02$ & $0,01 \pm 0,01$ & $0,11 \pm 0,01$ \\
\hline Estômago ${ }^{*}$ & $0,03 \pm 0,02$ & $0,12 \pm 0,09$ & $0,06 \pm 0,05$ & $0,22 \pm 0,2$ & $0,04 \pm 0,01$ & $0,18 \pm 0,12$ \\
\hline Fígado & $0,19 \pm 0,05$ & $0,19 \pm 0,04$ & $0,21 \pm 0,05$ & $0,20 \pm 0,06$ & $0,19 \pm 0,07$ & $0,19 \pm 0,04$ \\
\hline Rins & $0,75 \pm 0,14$ & $2,17 \pm 0,45$ & $1,00 \pm 0,09$ & $3,30 \pm 0,44$ & $0,6 \pm 0,04$ & $2,08 \pm 0,40$ \\
\hline Intestinos $^{* *}$ & $0,32 \pm 0,04$ & $0,17 \pm 0,13$ & $0,93 \pm 0,28$ & $0,40 \pm 0,21$ & $0,29 \pm 0,06$ & $0,13 \pm 0,03$ \\
\hline Músculo & $0,59 \pm 0,21$ & $0,07 \pm 0,03$ & $0,34 \pm 0,21$ & $0,04 \pm 0,03$ & $0,21 \pm 0,01$ & $0,03 \pm 0,01$ \\
\hline Esquelético & & & & & & \\
\hline Osso & $0,64 \pm 0,29$ & $0,24 \pm 0,03$ & $1,65 \pm 1,03$ & $0,70 \pm 0,49$ & $1,36 \pm 0,38$ & $0,52 \pm 0,04$ \\
\hline Cérebro & $0,01 \pm 0,01$ & $0,02 \pm 0,01$ & 0,00 & 0,00 & 0,00 & 0,00 \\
\hline Cerebelo & $0,01 \pm 0,01$ & $0,04 \pm 0,02$ & 0,00 & 0,00 & 0,00 & 0,00 \\
\hline
\end{tabular}

Estômago vazio. $^{* *}$ Intestinos com conteúdo. 
TABELA 11 - Biodistribuição do derivado da bombesina BEFG $_{4}$ radiomarcado com lutécio-177 (0,185 MBq) em camundongos Balb-c machos sadios ( $\mathrm{n}=5)$.

\begin{tabular}{|c|c|c|c|c|c|c|}
\hline Peptídeo & \multicolumn{6}{|c|}{ BEFG $_{4^{-}}{ }^{177} \mathbf{L u}$} \\
\hline Tempo após & \multicolumn{2}{|c|}{1 hora } & \multicolumn{2}{|c|}{4 horas } & \multicolumn{2}{|c|}{24 horas } \\
\hline $\begin{array}{c}\text { Unidade de } \\
\text { medida }\end{array}$ & $\% \mathrm{AI}$ & $\% \mathrm{AI} / \mathrm{g}$ & $\%$ AI & $\% \mathrm{AI} / \mathrm{g}$ & $\% \mathrm{AI}$ & $\% \mathrm{AI} / \mathrm{g}$ \\
\hline Próstata & $0,01 \pm 0,01$ & - & $0,02 \pm 0,01$ & - & 0,00 & - \\
\hline Coração & $0,03 \pm 0,01$ & $0,25 \pm 0,08$ & $0,01 \pm 0,00$ & $0,05 \pm 0,01$ & 0,00 & $0,02 \pm 0,01$ \\
\hline Pulmões & $0,12 \pm 0,11$ & $0,48 \pm 0,20$ & $0,03 \pm 0,01$ & $0,12 \pm 0,03$ & $0,01 \pm 0,00$ & $0,05 \pm 0,01$ \\
\hline Pâncreas & $0,09 \pm 0,08$ & $0,30 \quad 0,19$ & $0,02 \pm 0,01$ & $0,06 \pm 0,01$ & $0,01 \pm 0,00$ & $0,02 \pm 0,01$ \\
\hline Baço & $0,02 \pm 0,01$ & $0,31 \pm 0,13$ & $0,01 \pm 0,00$ & $0,09 \pm 0,02$ & $0,01 \pm 0,00$ & $0,05 \pm 0,02$ \\
\hline Estômago* & $0,05 \pm 0,02$ & $0,18 \pm 0,08$ & $0,08 \pm 0,04$ & $0,25 \pm 0,15$ & $0,01 \pm 0,00$ & $0,04 \pm 0,01$ \\
\hline Fígado & $0,27 \pm 0,15$ & $0,19 \pm 0,11$ & $0,17 \pm 0,02$ & $0,13 \pm 0,01$ & $0,11 \pm 0,01$ & $0,08 \pm 0,01$ \\
\hline Rins & $1,03 \pm 0,18$ & $2,96 \pm 0,94$ & $0,98 \pm 0,10$ & $2,16 \pm 0,12$ & $0,35 \pm 0,05$ & $0,81 \pm 0,14$ \\
\hline Intestinos $^{* *}$ & $0,44+0,12$ & $0,20+0,07$ & $0,65+0,30$ & $0,26 \pm 0,11$ & $0,23+0,03$ & $0,08+0,01$ \\
\hline Músculo & $2,17 \pm 0,70$ & $0,31 \pm 0,17$ & $0,57 \pm 0,28$ & $0,11 \pm 0,07$ & $0,13 \pm 0,04$ & $0,01 \pm 0,00$ \\
\hline Esquelético & & & & & & \\
\hline Osso & $1,27 \pm 0,63$ & $0,78 \pm 0,18$ & $1,43 \pm 0,56$ & $0,59 \pm 0,19$ & $1,05 \pm 0,48$ & $0,35 \pm 0,17$ \\
\hline Cérebro & $0,01 \pm 0,01$ & $0,05 \pm 0,02$ & 0,00 & $0,01 \pm 0,01$ & 0,00 & $0,02 \pm 0,01$ \\
\hline Cerebelo & $0,01 \pm 0,01$ & $0,08 \pm 0,05$ & 0,00 & $0,02 \pm 0,02$ & 0,00 & $0,02 \pm 0,01$ \\
\hline
\end{tabular}

*Estômago vazio. ${ }^{* *}$ Intestinos com conteúdo. 
TABELA 12 - Biodistribuição do derivado da bombesina BEFG $_{5}$ radiomarcado com lutécio-177 (0,185 MBq) em camundongos Balb-c machos sadios ( $\mathrm{n}=5)$.

\begin{tabular}{|c|c|c|c|c|c|c|}
\hline Peptídeo & \multicolumn{6}{|c|}{ BEFG $_{5}{ }^{177} \mathbf{L u}$} \\
\hline Tempo após & \multicolumn{2}{|c|}{1 hora } & \multicolumn{2}{|c|}{4 horas } & \multicolumn{2}{|c|}{24 horas } \\
\hline $\begin{array}{c}\text { Unidade de } \\
\text { medida }\end{array}$ & $\%$ AI & $\% \mathrm{AI} / \mathrm{g}$ & $\% A I$ & $\% \mathrm{AI} / \mathrm{g}$ & $\% A I$ & $\% \mathrm{AI} / \mathrm{g}$ \\
\hline Próstata & $0,06 \pm 0,05$ & - & $0,01 \pm 0,01$ & - & 0,00 & - \\
\hline Coração & $0,03 \pm 0,01$ & $0,2 \pm 0,07$ & $0,01 \pm 0,01$ & $0,05 \pm 0,01$ & 0,00 & $0,02 \pm 0,01$ \\
\hline Pulmões & $0,19 \pm 0,12$ & $0,61 \pm 0,3$ & $0,03 \pm 0,01$ & $0,1 \pm 0,04$ & $0,01 \pm 0,01$ & $0,05 \pm 0,01$ \\
\hline Pâncreas & $0,09 \pm 0,05$ & $0,19 \pm 0,06$ & $0,02 \pm 0,01$ & $0,05 \pm 0,01$ & $0,01 \pm 0,01$ & $0,03 \pm 0,01$ \\
\hline Baço & $0,02 \pm 0,01$ & $0,12 \pm 0,04$ & $0,01 \pm 0,01$ & $0,07 \pm 0,01$ & $0,01 \pm 0,01$ & $0,05 \pm 0,02$ \\
\hline Estômago ${ }^{*}$ & $0,05 \pm 0,02$ & $0,25 \pm 0,06$ & $0,02 \pm 0,01$ & $0,09 \pm 0,01$ & $0,01 \pm 0,01$ & $0,03 \pm 0,01$ \\
\hline Fígado & $0,27 \pm 0,05$ & $0,24 \pm 0,06$ & $0,17 \pm 0,01$ & $0,16 \pm 0,02$ & $0,13 \pm 0,03$ & $0,11 \pm 0,04$ \\
\hline Rins & $1,09 \pm 0,27$ & $2,74 \pm 0,67$ & $0,67 \pm 0,1$ & $1,93 \pm 0,29$ & $0,39 \pm 0,08$ & $0,93 \pm 0,27$ \\
\hline Intestinos $^{* *}$ & $0,42 \pm 0,18$ & $0,21 \pm 0,09$ & $0,2 \pm 0,02$ & $0,09 \pm 0,06$ & $0,09 \pm 0,04$ & $0,03 \pm 0,01$ \\
\hline Músculo & $1,17 \pm 0,66$ & $0,11 \pm 0,06$ & $0,24 \pm 0,08$ & $0,02 \pm 0,01$ & $0,17 \pm 0,09$ & $0,02 \pm 0,01$ \\
\hline Esquelético & & & & & & \\
\hline Osso & $0,96 \pm 0,15$ & $0,32 \pm 0,05$ & $0,83 \pm 0,09$ & $0,3 \pm 0,03$ & $0,81 \pm 0,22$ & $0,27 \pm 0,07$ \\
\hline Cérebro & $0,01 \pm 0,01$ & $0,01 \pm 0,01$ & 0,00 & $0,01 \pm 0,01$ & 0,00 & 0,00 \\
\hline Cerebelo & 0,00 & $0,02+0,01$ & 0,00 & $0,01 \pm 0,01$ & 0,00 & 0,00 \\
\hline
\end{tabular}

Estômago vazio. ${ }^{* *}$ Intestinos com conteúdo.

Concentração significativa da radioatividade pode ser observada nos rins até 24 horas após a administração, indicando que os derivados são excretados principalmente por via renal. Pequenas proteínas e peptídeos são reabsorvidos nos túbulos renais após a filtração glomerular. A reabsorção de peptídeos radiomarcados representa um problema em sua aplicação clínica, uma vez que os rins são órgãos críticos para a dosimetria na terapia 
radioisotópica e que a alta captação renal pode prejudicar a identificação de patologias nas estruturas adjacentes em exames de imagem. Essa alta captação renal de compostos radiomarcados pode ser evitada através da co-administração de aminoácidos catiônicos. Em terapia radioisotópica com derivados da somatostatina radiomarcados, aminoácidos como a lisina (Lys) e a arginina (Arg) são usualmente administrados por via endovenosa. A administração oral desses aminoácidos foi testada em animais e também reduziu a radioatividade nos rins. No entanto, no caso de derivados da bombesina, a coadministração de aminoácidos ou outros compostos protetores renais não provocou redução na captação renal, sugerindo pouca eficiência ou inespecifidade do mecanismo de reabsorção da bombesina e seus análogos (Gotthardt et al., 2007). Apesar do acúmulo renal dos derivados da bombesina estudados se mostrar proporcionalmente menores em relação a outros peptídeos radiomarcados (de Araújo et al., 2009) e comparável a outros derivados da bombesina (Lantry et al., 2006; Garayoa et al., 2007; Garrison et al., 2008), medidas preventivas podem ser adotadas para evitar dano renal e facilitar a aquisição da imagem, tais como alta ingestão de líquidos e aquisição de imagens tardias, no caso da aplicação clínica para tratamento ou identificação câncer prostático. Essas medidas preventivas se tornam ainda mais importantes quando se deseja visualizar o tumor primário localizado na proximidade entre a próstata, os rins e a bexiga, podendo causar a inconveniência da superposição das imagens.

A excreção renal associada à baixa captação hepática de todos os derivados estudados confirmou sua baixa lipossolubilidade, descrita anteriormente nos estudos de CLAE e coeficiente de partição. Entretanto, a relação entre a adição de aminoácidos glicina ao espaçador dos derivados e a discreta redução da lipossolubilidade não foi observada nos valores de captação hepática in vivo, exceto para o $\mathrm{BEFG}_{1}{ }^{177} \mathrm{Lu}^{1}$, cuja captação hepática é o dobro da observada para os demais derivados no mesmo tempo. Esses resultados sugerem que a redução na lipossolubilidade é muito pequena para provocar uma mudança na biotransformação e via de excreção dos derivados.

Na investigação em camundongos, o pâncreas e o intestino mostram ser tecidos que expressam receptores para o peptídeo liberador de gastrina em alta densidade e, portanto, representam um controle da ligação dos derivados da bombesina a esses receptores. A presença dos GRPr nesses tecidos é também responsável pelo acúmulo abdominal de muitos derivados da bombesina descritos anteriormente, os quais apresentam captação pancreática variando entre $2 \%$ e $60 \%$ da atividade injetada na primeira hora após a administração (Lantry et al., 2006; Garayoa et al., 2007; Zhang et al., 2007; Parry et al., 
2007a; Garrison et al., 2008). Os derivados $\mathrm{BEFG}_{1^{-}}{ }^{177} \mathrm{Lu}, \mathrm{BEFG}_{2^{-}}{ }^{177} \mathrm{Lu}, \mathrm{BEFG}_{3^{-}}{ }^{177} \mathrm{Lu}$, $\mathrm{BEFG}_{4^{-}}{ }^{177} \mathrm{Lu}$ e $\mathrm{BEFG}_{5}{ }^{177} \mathrm{Lu}$ apresentam baixa captação pancreática e apenas uma discreta captação intestinal, que também pode decorrer da reabsorção e posterior excreção de uma pequena fração na bile. A baixa captação nesses dois tecidos poderia sugerir ausência de captação tumoral, mas alguns estudos indicam que não há relação entre a captação pancreática ou intestinal e tumoral para os derivados de bombesina radiomarcados (La Bella et al., 2002; Lane et al., 2008).

A captação óssea é comumente assumida como um controle da estabilidade in vivo de moléculas radiomarcadas com lutécio. Esse tecido capta ativamente o lutécio não ligado, sendo um bom indicador da pureza radioquímica das marcações e de estabilidade in vivo frente à descomplexação, principalmente nos tempos iniciais. A captação óssea dos derivados radiomarcados foi insignificante se comparada à do ${ }^{177} \mathrm{Lu}$ não ligado, a qual atinge níveis de $10 \%$ da atividade injetada apenas no fêmur 2 horas após a administração (Haley et al., 1964; Jiménez, 2007). Esses resultados confirmam a ausência de contaminação por esse radiolantanídeo nas preparações, conforme demonstrado na cromatografia em camada delgada e na cromatografia líquida de alta eficiência.

Pelos resultados de baixa captação prostática confirmaram-se os dados da literatura consultada de que a próstata normal ou hiperplásica é negativa para os receptores GRP, enquanto esses receptores são encontrados em alta densidade no adenocarcinoma de próstata (Markwalder e Reubi, 1999).

\subsubsection{Estudos farmacocinéticos em camundongos Balb-c sadios}

Para que um fármaco exerça seu efeito em um determinado local de ação no interior de um organismo vivo, é necessário que ele atravesse várias das barreiras celulares até atingir seu local de ação. Um fármaco é distribuído pelo organismo através da circulação sanguínea, e sua distribuição entre os tecidos é um processo dinâmico. Similarmente, a eventual eliminação desse fármaco é também um processo dinâmico, dependente da probabilidade do fármaco alcançar o órgão excretor e de sua interação com os processos bioquímicos responsáveis pela sua eliminação. Consequentemente, o fenômeno tempo-dependente de distribuição e eliminação de um fármaco é primariamente complexo e para melhor compreendê-lo se traduz matematicamente o fenômeno dinâmico a um fenômeno determinístico (Vaughan, 1990).

A farmacocinética se origina da observação das concentrações de um fármaco em função do tempo como exponenciais únicas. Essas exponenciais isoladas resultam na 
tradução da disposição do fármaco em um modelo composto por um, dois, três ou vários compartimentos. Esses modelos são então denominados, respectivamente, monocompartimental, bicompartimental e multicompartimental (Vaughan, 1990).

Os resultados da análise farmacocinética dos derivados podem ser visualizados isoladamente e em conjunto na FIG. 30. A concentração dos derivados foi medida em um contador gama após a coleta de $60 \mu \mathrm{L}$ de sangue pelo plexo orbital dos camundongos Balb-c até 24 horas após a administração endovenosa dos peptídeos radiomarcados. Todos os derivados apresentaram rápido clareamento sanguíneo e suas concentrações no sangue se tornaram praticamente indetectáveis 120 minutos após a administração endovenosa.

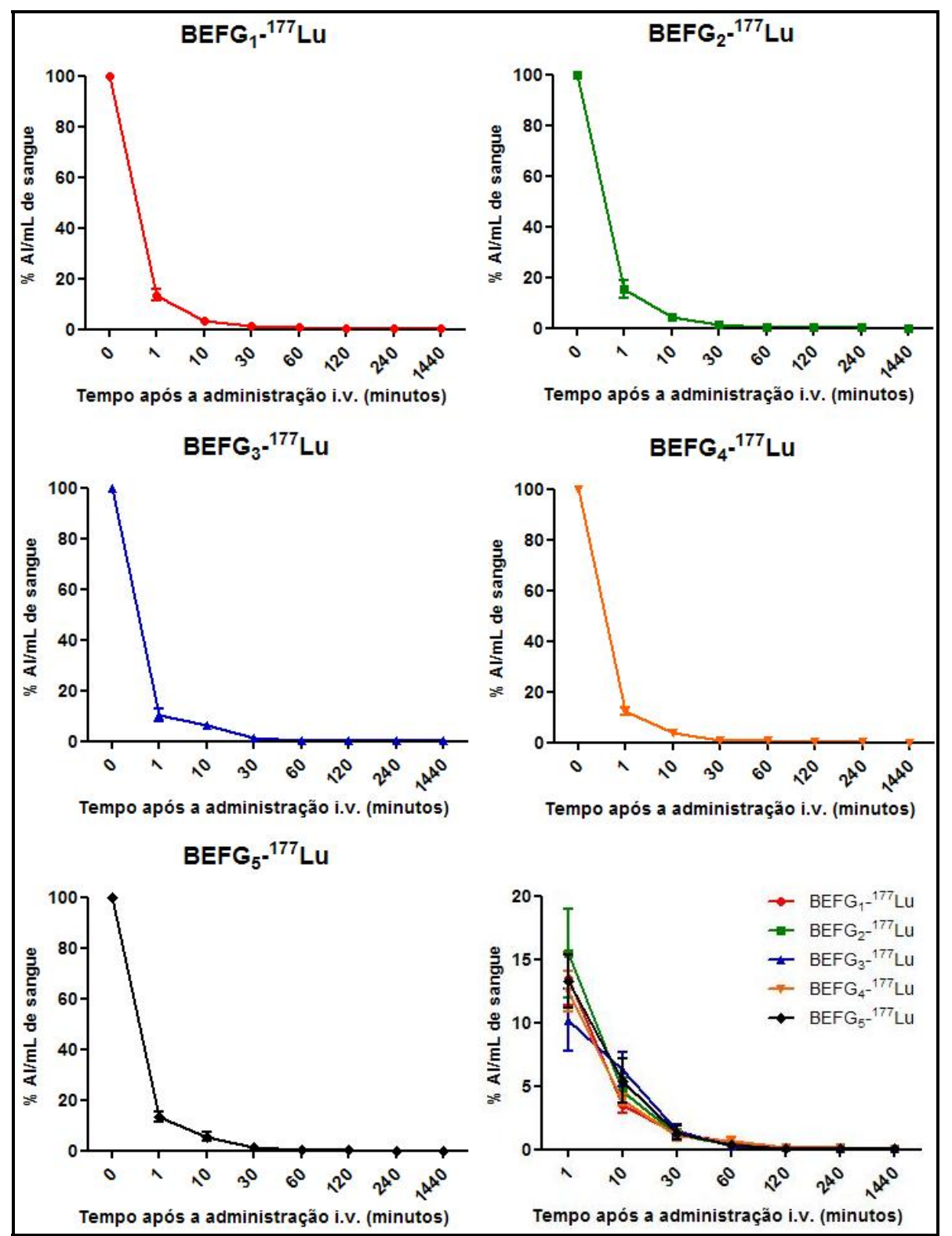

FIGURA 30 - Curvas farmacocinéticas do $\mathrm{BEFG}_{1}, \mathrm{BEFG}_{2}, \mathrm{BEFG}_{3}, \mathrm{BEFG}_{4}$ e $\mathrm{BEFG}_{5}$ radiomarcados com ${ }^{177} \mathrm{Lu}(\mathrm{n}=5)$. 
As curvas da FIG. 30 foram utilizadas para cálculo dos parâmetros farmacocinéticos dos derivados radiomarcados através do programa Biexp. Esse programa aproxima as curvas de clareamento sanguíneo para um modelo biexponencial, com uma componente de clareamento rápido e uma de clareamento lento. Apesar de as curvas cinéticas sugerirem que o modelo de distribuição dos derivados radiomarcados é do tipo multicompartimental, o programa Biexp é útil para análise comparativa entre fármacos da mesma natureza.

As equações 9, 10, 11, 12 e 13, obtidas através do programa Biexp, caracterizam a variação da concentração sanguínea $\mathrm{C}(\mathrm{t})$ dos derivados $\mathrm{BEFG}_{1^{-}}{ }^{177} \mathrm{Lu}$, $\mathrm{BEFG}_{2^{-}}{ }^{177} \mathrm{Lu}, \mathrm{BEFG}_{3^{-}}{ }^{177} \mathrm{Lu}, \mathrm{BEFG}_{4^{-}}{ }^{177} \mathrm{Lu}$ e $\mathrm{BEFG}_{5^{-}}{ }^{177} \mathrm{Lu}$ em função do tempo t, respectivamente. Essas equações ilustram a aproximação do modelo de distribuição para dois compartimentos, gerando duas funções exponenciais positivas.

$$
\begin{gathered}
C(t)=694844,69^{-5,11 t}+11558,15^{-0,11 t} \\
C(t)=736715,69^{-5,49 t}+13405,34^{-0,284 t} \\
C(t)=623853,50^{-5,12 t}+5815,18^{-0,14 t} \\
C(t)=813742,94^{-6,14 t}+16063,54^{-0,12 t} \\
C(t)=820382,56^{-4,45 t}+7539,17^{0,19 t}
\end{gathered}
$$

Os parâmetros farmacocinéticos calculados pelo programa Biexp são apresentados na TAB. 13. Os resultados de depuração, ou seja, eficácia do organismo em eliminar o radiofármaco sugere rápido clareamento sanguíneo e rápida excreção, a qual, de acordo com os resultados dos estudos de biodistribuição, é realizada principalmente por via renal.

A meia-vida é o tempo necessário para a concentração sanguínea ou a quantidade de fármaco no organismo ser reduzida à metade, ou seja, 50\% (Wilkinson, 2003). Pode-se observar, de acordo com os dados mostrados, que os derivados radiomarcados não diferem significativamente quando se compara os tempos de meia-vida da fase exponencial rápida. Esses $T_{1 / 2}$ curtos, associados aos valores de depuração, refletem, mais uma vez, o rápido clareamento sanguíneo e rápida excreção. É importante ressaltar que a rápida eliminação do sangue é fundamental para evitar o metabolismo dos derivados pelas enzimas do soro in vivo, conforme demonstrado in vitro. 
Além da meia-vida sanguínea e da depuração, outro parâmetro farmacocinético importante na avaliação do comportamento de um fármaco no organismo é o volume de distribuição, ou seja, a medida do volume de plasma disponível para conter o fármaco. $\mathrm{O}$ volume de distribuição é um parâmetro fundamental ao considerar os mecanismos de transporte aos quais o fármaco é submetido. O volume de distribuição relaciona a quantidade de fármaco no organismo com a sua concentração sanguínea. Esse volume não se refere necessariamente a um volume fisiológico identificável, porém ao volume líquido que seria necessário para conter todo o fármaco do corpo na mesma concentração do sangue. O volume de distribuição reflete, portanto, a extensão em que o fármaco está presente nos tecidos extravasculares (Wilkinson, 2003). Apesar da discreta diferença entre a farmacocinética dos derivados estudados e da dificuldade em estabelecer uma relação entre os resultados dos estudos cinéticos e sua estrutura, o derivado $\mathrm{BEFG}_{1^{-}}{ }^{177} \mathrm{Lu}$, o mais lipossolúvel de acordo com os estudos de coeficiente de partição e CLAE, apresentou uma maior distribuição nos tecidos dos camundongos Balb-c. Esse resultado sugere que a maior lipofilicidade dificulta a excreção renal, e também foi demonstrado pela menor constante de transferência do espaço vascular para o sistema excretor $\left(\mathrm{K}_{10}\right)$. 
TABELA 13 - Parâmetros farmacocinéticos para os derivados da bombesina $\mathrm{BEFG}_{1}$, $\mathrm{BEFG}_{2}, \quad \mathrm{BEFG}_{3}, \quad \mathrm{BEFG}_{4}$ e $\mathrm{BEFG}_{5}$ radiomarcados com ${ }^{177} \mathrm{Lu}$ determinados utilizando o programa Biexp.

\begin{tabular}{|c|c|c|c|c|c|}
\hline $\begin{array}{c}\text { Parâmetro } \\
\text { Farmacocinético }\end{array}$ & $\begin{array}{l}\text { BEFG }_{1^{-}} \\
{ }^{177} \mathbf{L u}\end{array}$ & $\begin{array}{c}\text { BEFG }_{2^{-}} \\
{ }^{177} \mathbf{L u}\end{array}$ & $\begin{array}{l}\text { BEFG }_{3-} \\
{ }^{177} \mathbf{L u}\end{array}$ & $\begin{array}{c}\text { BEFG }_{4^{-}} \\
{ }^{177} \mathbf{L u}\end{array}$ & $\begin{array}{l}\text { BEFG }_{5-} \\
{ }^{177} \mathbf{L u}\end{array}$ \\
\hline $\begin{array}{c}\mathrm{T}_{1 / 2} \text { fase exponencial } \\
\text { rápida (min) }\end{array}$ & 8,4 & 7,8 & 8,4 & 6,6 & 9,6 \\
\hline $\begin{array}{c}\mathrm{T}_{1 / 2} \text { fase exponencial } \\
\text { lenta }(\mathrm{min})\end{array}$ & 369 & 329 & 294 & 336 & 222 \\
\hline${ }^{*} \mathrm{~K}_{12}\left(\mathrm{~h}^{-1}\right)$ & 2,06 & 1,28 & 1,20 & 2,87 & 0,71 \\
\hline${ }^{* *} \mathrm{~K}_{21}\left(\mathrm{~h}^{-1}\right)$ & 0,19 & 0,37 & 0,19 & 0,24 & 0,23 \\
\hline${ }^{* * *} \mathrm{~K}_{10}\left(\mathrm{~h}^{-1}\right)$ & 1,39 & 4,11 & 3,86 & 3,16 & 3,70 \\
\hline $\begin{array}{l}\text { Volume de distribuição } \\
\qquad(\mathrm{mL})\end{array}$ & 93,10 & 31,76 & 42,14 & 87,22 & 28,66 \\
\hline Depuração $\left(\mathrm{mL} \cdot \mathrm{h}^{-1}\right)$ & 23,69 & 29,20 & 22,02 & 21,28 & 25,55 \\
\hline${ }^{* * * *} \mathrm{~K}_{\mathrm{ss}}\left(\mathrm{h}^{-1}\right)$ & 0,25 & 0,91 & 0,52 & 0,24 & 0,89 \\
\hline
\end{tabular}

"Constante de transferência do espaço vascular para o extravascular; ${ }^{* *}$ Constante de transferência do espaço extravascular para o vascular; ${ }^{* * *}$ Constante de transferência do espaço vascular para o sistema excretor; ${ }^{* * * *}$ Constante de eliminação

Fármacos administrados por via endovenosa são rapidamente distribuídos em todo o sistema vascular de onde são transportados a vários tecidos, inclusive para aqueles responsáveis por sua excreção e metabolismo (Tozer, 1990). Analisando-se as curvas de clareamento sanguíneo dos derivados radiomarcados, mostradas anteriormente na FIG. 30, pode-se identificar cinco componentes exponenciais, cada uma correspondente a um compartimento de distribuição. Portanto, o modelo de biodistribuição observado para os derivados da bombesina estudados mostra ser do tipo multicompartimental.

Considerando-se cada exponencial isoladamente, é possível calcular o tempo de meia-vida $\left(\mathrm{T}_{1 / 2}\right)$ dos derivados radiomarcados em cada um dos cinco compartimentos, por meio da equação: 


$$
T_{1 / 2}=\frac{\left(T_{f}-T_{i}\right) \times A_{i}}{\left(A_{i}-A_{f}\right) \times 2}
$$

Em que $\mathrm{T}_{\mathrm{f}}$ é o tempo final, $\mathrm{T}_{\mathrm{i}}$ é o tempo inicial, $\mathrm{A}_{\mathrm{i}}$ é a atividade no sangue no tempo inicial e $A_{f}$ é a atividade no sangue no tempo final.

Na TAB. 14 apresentam-se os resultados de tempo de meia-vida, calculados manualmente, dos derivados radiomarcados nos cinco compartimentos identificados a partir de suas curvas de cinética sanguínea, calculados utilizando-se a EQ. 14. A primeira, de decaimento muito rápido, corresponde ao intervalo de tempo entre zero e 1 minuto $\left(\mathrm{T}_{1 / 2}^{1}\right)$. As duas exponenciais seguintes apresentam decaimento rápido e correspondem aos intervalos de tempo entre um e 10 minutos $\left(\mathrm{T}_{1 / 2}^{2}\right)$ e 10 e 30 minutos $\left(\mathrm{T}_{1 / 2}^{3}\right)$ após a administração endovenosa. A quarta exponencial apresenta decaimento mais lento do que as duas primeiras e corresponde ao intervalo de tempo entre 30 e 120 minutos $\left(\mathrm{T}_{1 / 2}^{4}\right)$. Já a quinta exponencial, de decaimento muito lento, corresponde ao intervalo de tempo entre 120 e 1440 minutos $\left(\mathrm{T}_{1 / 2}^{5}\right)$.

Pode-se observar que, da mesma forma que o observado com os dados obtidos através do programa Biexp, de acordo com os valores calculados, os derivados radiomarcados não diferem significativamente quando se compara os quatro primeiros tempos de meia-vida da curva de clareamento sanguíneo, ou seja, os $\mathrm{T}_{1 / 2}$ curtos.

A diferença nos valores de tempo de meia-vida dos derivados radiomarcados foi observada apenas na quinta exponencial, de decaimento mais lento. No entanto, da mesma forma que o observado para os valores obtidos através do programa Biexp, não foi possível estabelecer uma relação entre a estrutura dos derivados e os valores de $\mathrm{T}^{1 / 2} 2^{5}$, sugerindo que a alteração em suas estruturas é muito pequena para provocar uma mudança no clareamento sanguíneo dos derivados. A diferença observada pode ser decorrente da concentração praticamente indetectável dos derivados radiomarcados no sangue a partir de 120 minutos. Uma pequena alteração nessas concentrações altera significativamente a inclinação da quinta exponencial ou da exponencial lenta do programa Biexp e, consequentemente o valor de tempo de meia-vida calculado. 
TABELA 14 - Tempos de meia-vida dos derivados da bombesina radiomarcados em cada um dos compartimentos identificados a partir das curvas de clareamento sanguíneo.

\begin{tabular}{|c|c|c|c|c|c|}
\hline \multirow{3}{*}{$\begin{array}{c}\text { Derivado da } \\
\text { bombesina }\end{array}$} & \multicolumn{5}{|c|}{ Tempo de meia-vida $\left(T_{1 / 2}\right)$ do derivado em cada compartimento } \\
\hline & \multicolumn{5}{|c|}{ (min) } \\
\hline & $\mathbf{T}_{1 / 2}^{1}$ & $\mathbf{T}_{1 / 2}^{2}$ & $\mathbf{T}_{1 / 2}^{3}$ & $\mathbf{T}_{1 / 2}^{4}$ & $\mathbf{T}_{1 / 2}{ }^{5}$ \\
\hline $\mathrm{BEFG}_{1^{-}}{ }^{177} \mathrm{Lu}$ & 0,57 & 6,08 & 15,59 & 51,65 & 1565,81 \\
\hline $\mathrm{BEFG}_{2-}{ }^{177} \mathrm{Lu}$ & 0,59 & 6,38 & 13,37 & 50,90 & 792,14 \\
\hline $\mathrm{BEFG}_{3^{-}}{ }^{177} \mathrm{Lu}$ & 0,55 & 11,80 & 13,15 & 48,96 & 3309,04 \\
\hline $\mathrm{BEFG}_{4^{-}}{ }^{177} \mathrm{Lu}$ & 0,57 & 6,55 & 13,67 & 53,40 & 728,35 \\
\hline $\mathrm{BEFG}_{5^{-}}{ }^{177} \mathrm{Lu}$ & 0,58 & 7,58 & 13,12 & 49,36 & 1356,47 \\
\hline
\end{tabular}

Os resultados dos estudos de biodistribuição juntamente com a análise farmacocinética permitem propor os cinco principais compartimentos do organismo nos quais os derivados radiomarcados são distribuídos. Esses compartimentos estão ilustrados na FIG. 31 e consistem no compartimento central ou vascular; nos rins, órgãos de eliminação primária; no fígado e no intestino, órgãos de biotransformação e eliminação tardia; nos músculos e no osso, tecido que acumula o lutécio livre ou não ligado. As constantes " $\mathrm{K}$ " representam a transferência dos radiofármacos entre esses compartimentos. 


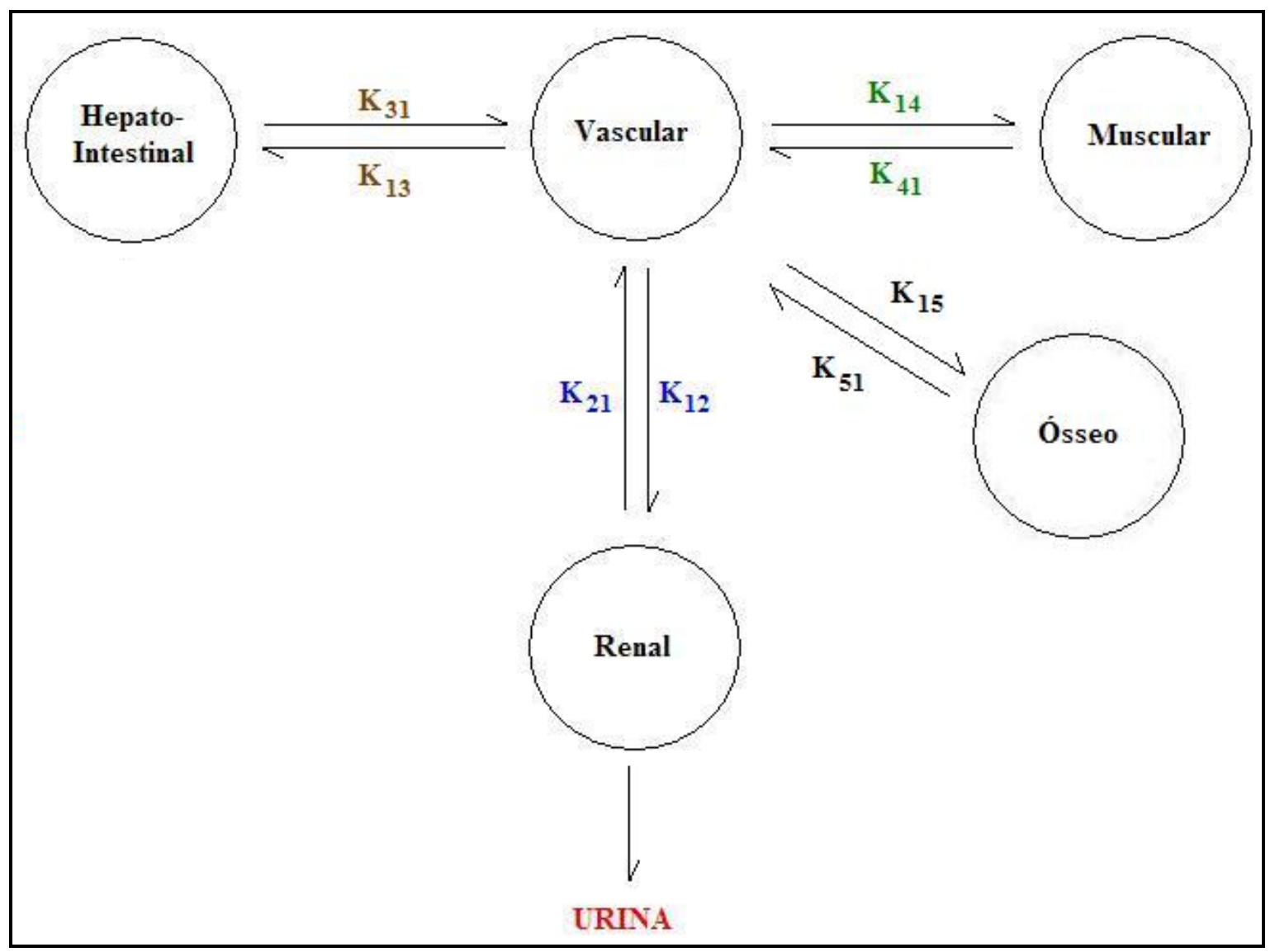

FIGURA 31 - Principais compartimentos do organismo nos quais os derivados da bombesina radiomarcados estão distribuídos.

\subsubsection{Estudos de corpo inteiro em camundongos Balb-c sadios}

Os fármacos inalterados ou seus metabólitos são excretados por diferentes vias, conforme suas propriedades físico-químicas. Compostos suficientemente polares ou hidrossolúveis são excretados predominantemente pelos rins (Oga e Yasaka, 1985). De acordo com os estudos de coeficiente de partição, os quais mostraram baixa lipossolubilidade dos derivados da bombesina, e com os estudos de biodistribuição, os quais mostraram alta captação renal, definiu-se a via renal como a principal via de excreção dos derivados da bombesina radiomarcados com lutécio-177.

A excreção de fármacos na urina é resultante de três processos renais: filtração glomerular, secreção tubular e reabsorção tubular. $\mathrm{Na}$ filtração glomerular, somente fármacos combinados às proteínas ou moléculas grandes são retidas no compartimento sanguíneo. As substâncias altamente lipossolúveis, após sofrerem filtração glomerular, são reabsorvidas por difusão passiva nos túbulos renais. Através dos rins, portanto, são eliminadas substâncias polares e suficientemente hidrossolúveis. A secreção tubular contribui igualmente na eliminação de fármacos do organismo (Oga e Yasaka, 1985). 
Nesse caso, a secreção ocorre nos túbulos renais proximais e é mediada por transportadores (Wilkinson, 2003). Os fármacos excretados por filtração glomerular e secreção tubular apresentam meia-vida biológica curta (Oga e Yasaka, 1985).

A fim de predizer o tempo de residência no organismo e a excreção dos derivados da bombesina, estudos de corpo inteiro foram realizados em camundongos Balb$c$ sadios. Os resultados, expressos em porcentagem da atividade injetada relacionada à quantidade retida no organismo em função do tempo, após a administração endovenosa, são mostrados na FIG. 32.

Pode-se observar, pelos dados mostrados, que o perfil de eliminação dos derivados da bombesina radiomarcados é semelhante, e que apenas uma pequena fração do total injetado ainda permanece retida no organismo 4 horas após a administração. $O$ derivado mais hidrossolúvel - $\mathrm{BEFG}_{5^{-}}{ }^{177} \mathrm{Lu}$ - foi mais rapidamente eliminado e sua concentração no organismo atingiu a linha base duas horas e trinta minutos após a administração. Os demais derivados necessitaram de intervalo superior a 4 horas para alcançar concentração no mesmo patamar.

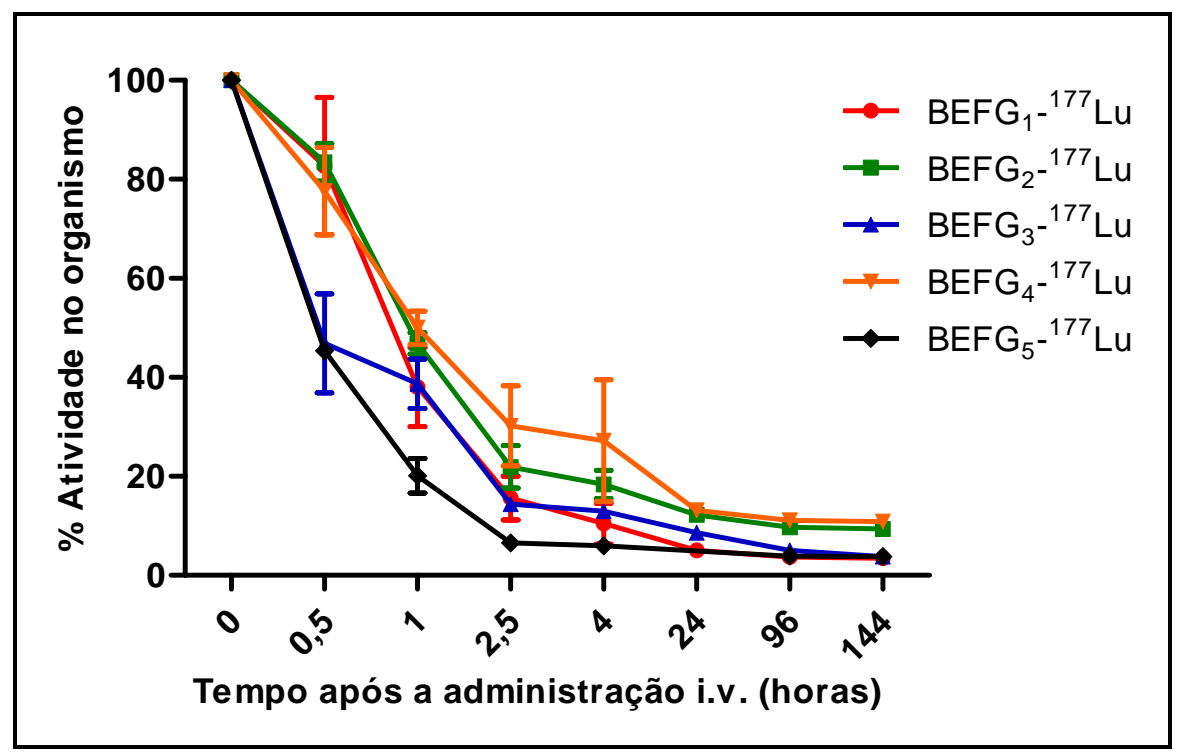

FIGURA 32 - Estudo de corpo inteiro dos derivados da bombesina radiomarcados com ${ }^{177} \mathrm{Lu}$ em camundongos Balb-c $(\mathrm{n}=4)$.

Os resultados mostrados anteriormente na FIG. 30 foram utilizados para cálculo da porcentagem média dos derivados da bombesina excretada ao longo do tempo decorrido após sua administração por via endovenosa e os dados são apresentados na TAB. 15. Todos os derivados radiomarcados apresentaram excreção de pelo menos $50 \%$ da atividade injetada até 1 hora após a administração. Esse valor chega próximo de $90 \%$ após 
24 horas e permanece praticamente estável até 144 horas, sugerindo retenção de uma pequena fração dos radiofármacos no organismo. Essa retenção pode ser decorrente da biotransformação de uma pequena fração injetada, que provavelmente leva à quebra das moléculas e liberação do lutécio-177, que é então captado pelos ossos. A biotransformação pode ser comprovada pela captação hepática significativa nos estudos de biodistribuição e a liberação do lutécio-177 pode ser comprovada pela captação óssea observada para todos os derivados nos mesmos estudos (TAB. 8, 9, 10,11 e 12).

As diferenças observadas na retenção e na excreção dos derivados da bombesina, principalmente 30 minutos após a administração, podem refletir a variação no estado de hidratação dos animais no instante da injeção. Animais com bexiga cheia provavelmente apresentaram excreção mais rápida dos radiofármacos, enquanto que animais com bexiga vazia demandaram mais tempo para excretá-los. Consequentemente, uma menor excreção na primeira hora refletiu em uma maior retenção do radiofármaco no organismo. Esse dado pode orientar sobre os cuidados envolvidos na futura aplicação clínica desses derivados para diagnóstico ou terapia de tumor de próstata. Pacientes em bom estado de hidratação ou orientados a ingerir grandes quantidades de líquido durante o procedimento diagnóstico ou terapêutico provavelmente apresentarão dosimetria menor e também efeitos adversos menores.

TABELA 15 - Porcentagem da atividade dos derivados da bombesina excretada ao longo do tempo decorrido após a administração endovenosa.

\begin{tabular}{cccccc}
\hline \multirow{2}{*}{$\begin{array}{c}\text { Tempo após a } \\
\text { administração }\end{array}$} & \multicolumn{5}{c}{ Atividade excretada (\%) } \\
\cline { 2 - 6 } (horas) & $\mathbf{B E F G}_{\mathbf{1}^{-}}$ & $\mathbf{B E F G}_{\mathbf{2}^{-}}$ & $\mathbf{B E F G}_{\mathbf{3}^{-}}$ & $\mathbf{B E F G}_{\mathbf{4}^{-}}$ & $\mathbf{B E F G}_{5^{-}}$ \\
0,5 & $\mathbf{1 7 7}_{\mathbf{L u}}$ & ${ }^{\mathbf{1 7 7} \mathbf{L u}}$ & ${ }^{\mathbf{1 7 7} \mathbf{L u}}$ & ${ }^{\mathbf{1 7 7} \mathbf{L u}}$ & $\mathbf{1 7 7}_{\mathbf{L u}}$ \\
\cline { 2 - 6 } 1 & $17,3 \pm 2,9$ & $16,6 \pm 0,8$ & $53,1 \pm 11,3$ & $22,4 \pm 2,5$ & $54,6 \pm 1,1$ \\
2,5 & $61,9 \pm 13,0$ & $53,1 \pm 2,5$ & $61,3 \pm 7,9$ & $50,0 \pm 3,4$ & $79,9 \pm 13,8$ \\
4 & $84,4 \pm 23,8$ & $78,1 \pm 15,4$ & $85,6 \pm 7,9$ & $69,8 \pm 18,6$ & $93,5 \pm 8,0$ \\
24 & $94,9 \pm 9,4$ & $87,8 \pm 8,2$ & $91,4 \pm 7,9$ & $86,8 \pm 6,8$ & $95,4 \pm 2,7$ \\
96 & $96,3 \pm 11,8$ & $90,3 \pm 12,1$ & $94,9 \pm 14,8$ & $88,9 \pm 5,7$ & $96,2 \pm 3,3$ \\
144 & $96,5 \pm 12,3$ & $90,6 \pm 13,0$ & $96,2 \pm 12,2$ & $89,2 \pm 6,1$ & $96,2 \pm 0,8$ \\
\hline
\end{tabular}




\subsubsection{Estudos de imagem em camundongos Balb-c sadios}

As FIG. 33, 34, 35, 36, e 37 ilustram as imagens cintilográficas adquiridas em diferentes tempos após a administração endovenosa dos derivados da bombesina em camundongos Balb-c. Essas imagens confirmaram os resultados obtidos nos estudos de biodistribuição, farmacocinética e corpo inteiro descritos anteriormente. Áreas com maior concentração de atividade são mostradas em negro, seguidas em ordem decrescente de atividade pelas cores laranja, amarelo, verde, azul, vermelho e cinza.

A baixa radiação de fundo das imagens e a alta concentração radioativa nos rins e na bexiga 30 minutos e 1 hora após a administração confirmaram a rápida eliminação sanguínea e rápida excreção, mostradas nos estudos de farmacocinética e biodistribuição, respectivamente. A baixa radiação detectada em todo o organismo 4 horas após a administração evidenciou a baixa retenção de todos os derivados radiomarcados no organismo, mostrada nos estudos de corpo inteiro. Além disso, observou-se uma distribuição e excreção mais rápida dos derivados menos lipossolúveis - $\mathrm{BEFG}_{4^{-}}{ }^{177} \mathrm{Lu}$ e $\mathrm{BEFG}_{5^{-}}{ }^{177} \mathrm{Lu}$. As imagens desses derivados mostraram radiação de fundo significativamente menor em relação aos demais derivados uma hora após a administração.

Um grande inconveniente dos derivados da bombesina radiomarcados descritos pela literatura é o seu alto acúmulo abdominal, especialmente no pâncreas e no intestino (Johnson et al., 2006; Lantry et al., 2006; Zhang et al., 2007; Faintuch et al., 2008). Esse acúmulo compromete a aplicação clínica dos derivados destinados ao diagnóstico, por dificultar a varredura de corpo inteiro e a localização do sítio tumoral, e dos derivados destinados à terapia, por acarretar sérios efeitos adversos aos pacientes. Assim como os estudos de biodistribuição, as imagens cintilográficas mostraram que, apesar de os derivados da bombesina radiomarcados apresentarem uma discreta captação abdominal, essa captação é significativamente menor em relação aos derivados descritos até o presente (Hu et al., 2002; Zhang et al., 2004; Stangelberger et al., 2005; Prasanphanic et al., 2007; Lane et al., 2008; Garrison et al., 2008).

Imagens normalizadas por tempo são difíceis de comparar, especialmente devido à baixa resolução nos tempos mais tardios. No entanto, elas são úteis para o propósito do presente trabalho, que foi comparar a distribuição dos derivados quanto à possibilidade de aquisição de imagens em um mesmo tempo. 


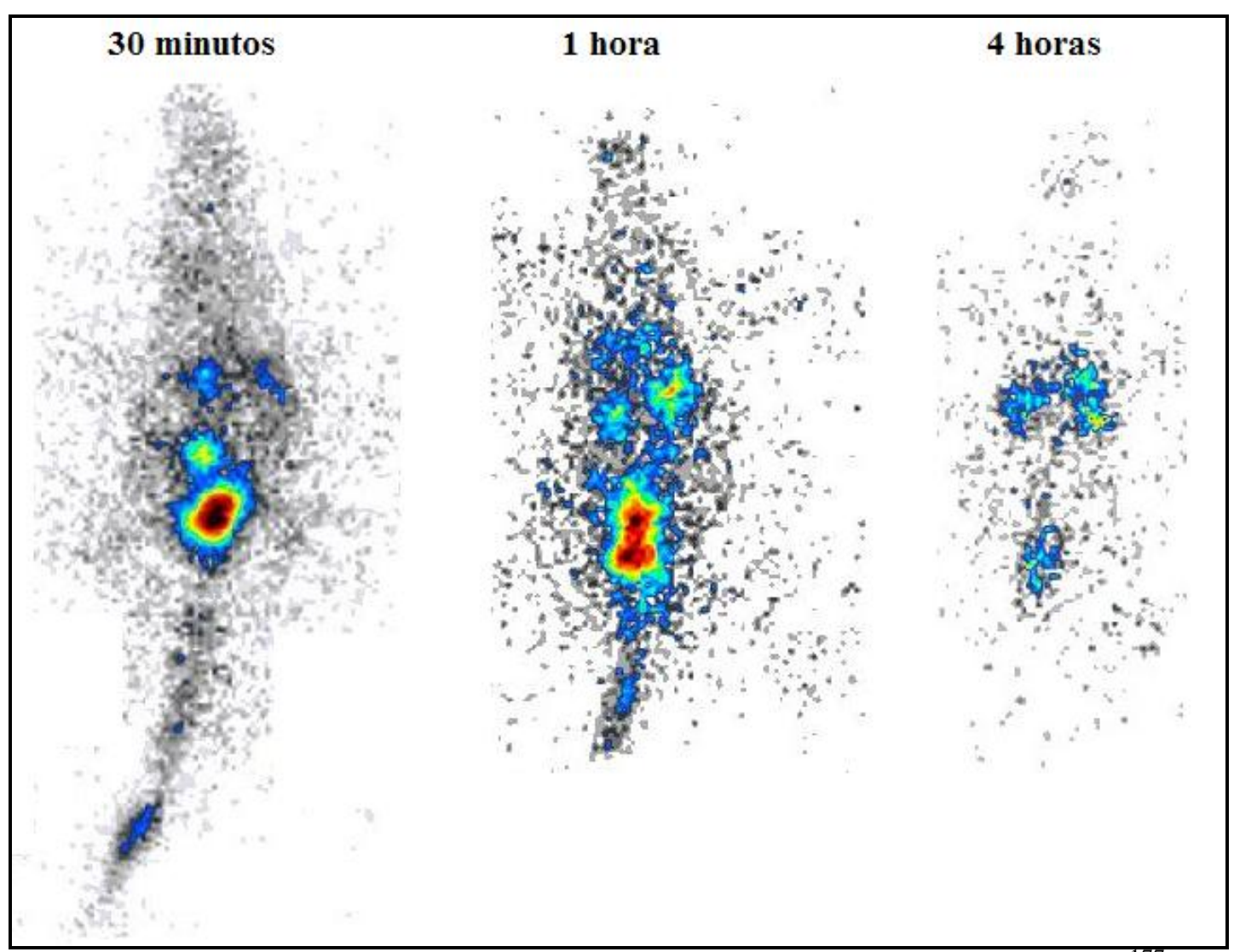

FIGURA 33 - Imagens cintilográficas do derivado da bombesina $\mathrm{BEFG}_{1^{-}}{ }^{177} \mathrm{Lu}$ em camundongos Balb-c machos.

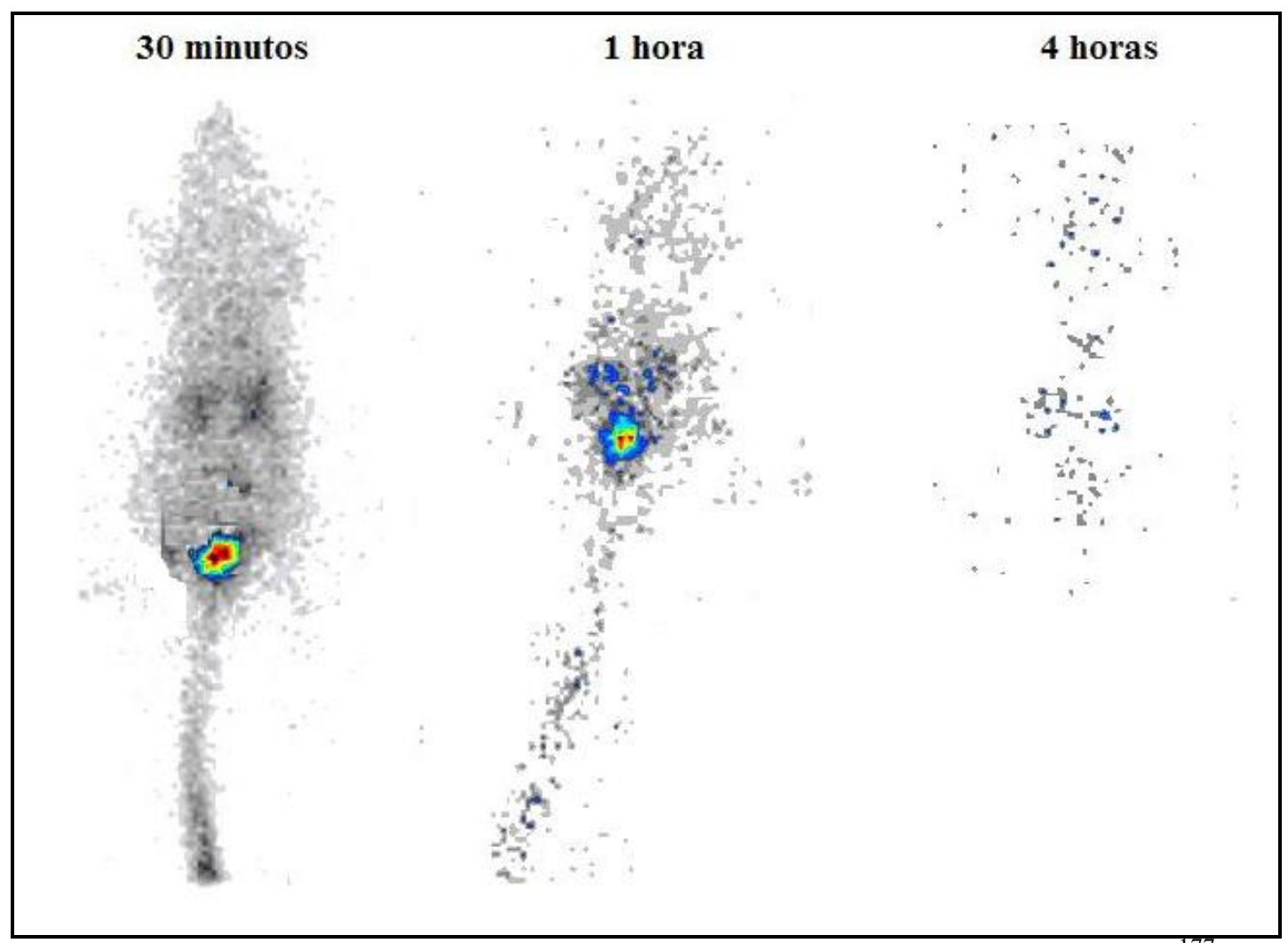

FIGURA 34 - Imagens cintilográficas do derivado da bombesina $\mathrm{BEFG}_{2^{-}}{ }^{177} \mathrm{Lu}$ em camundongos Balb-c machos. 


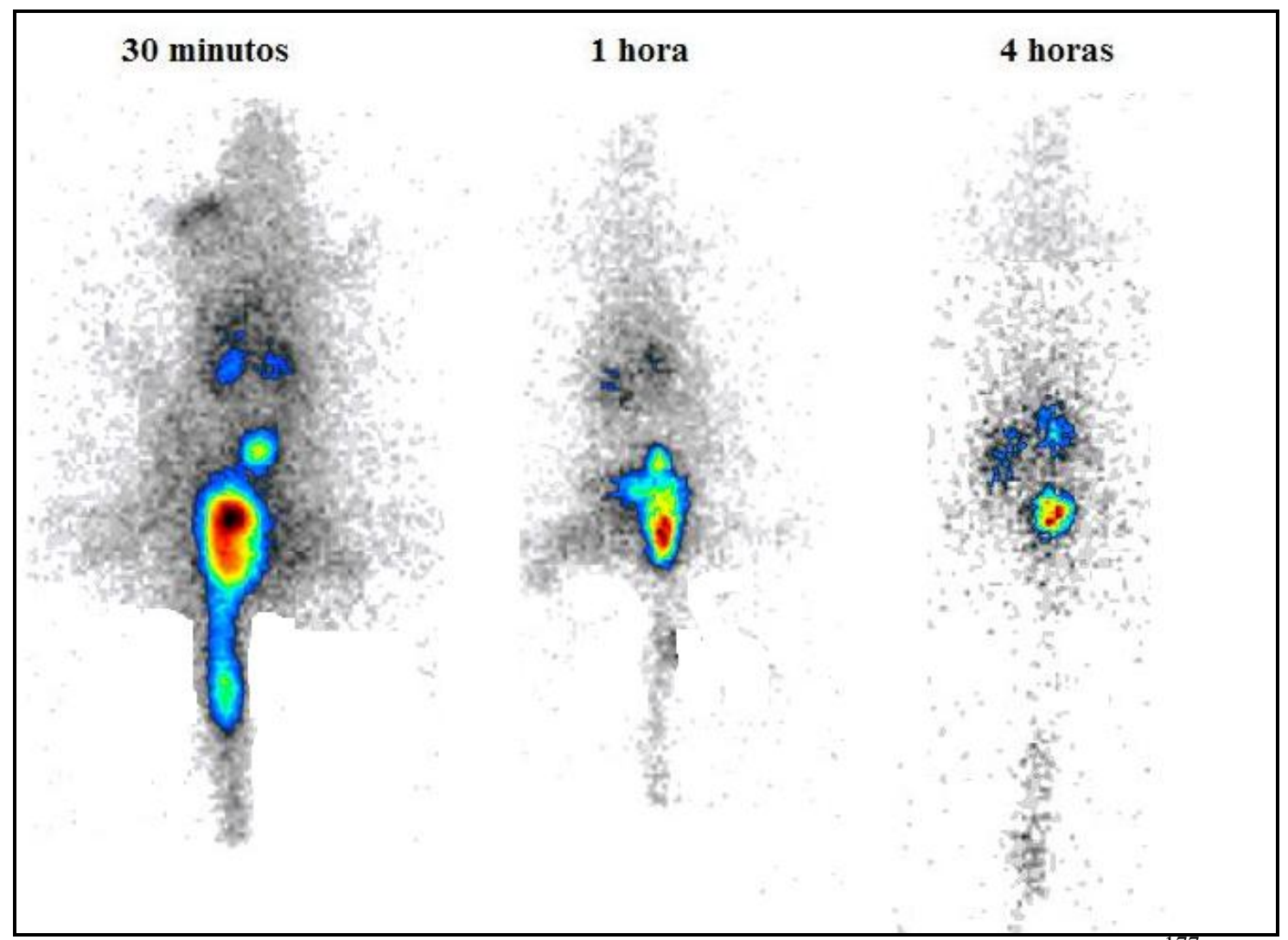

FIGURA 35 - Imagens cintilográficas do derivado da bombesina $\mathrm{BEFG}_{3^{-}}{ }^{177} \mathrm{Lu}$ em camundongos Balb-c machos.

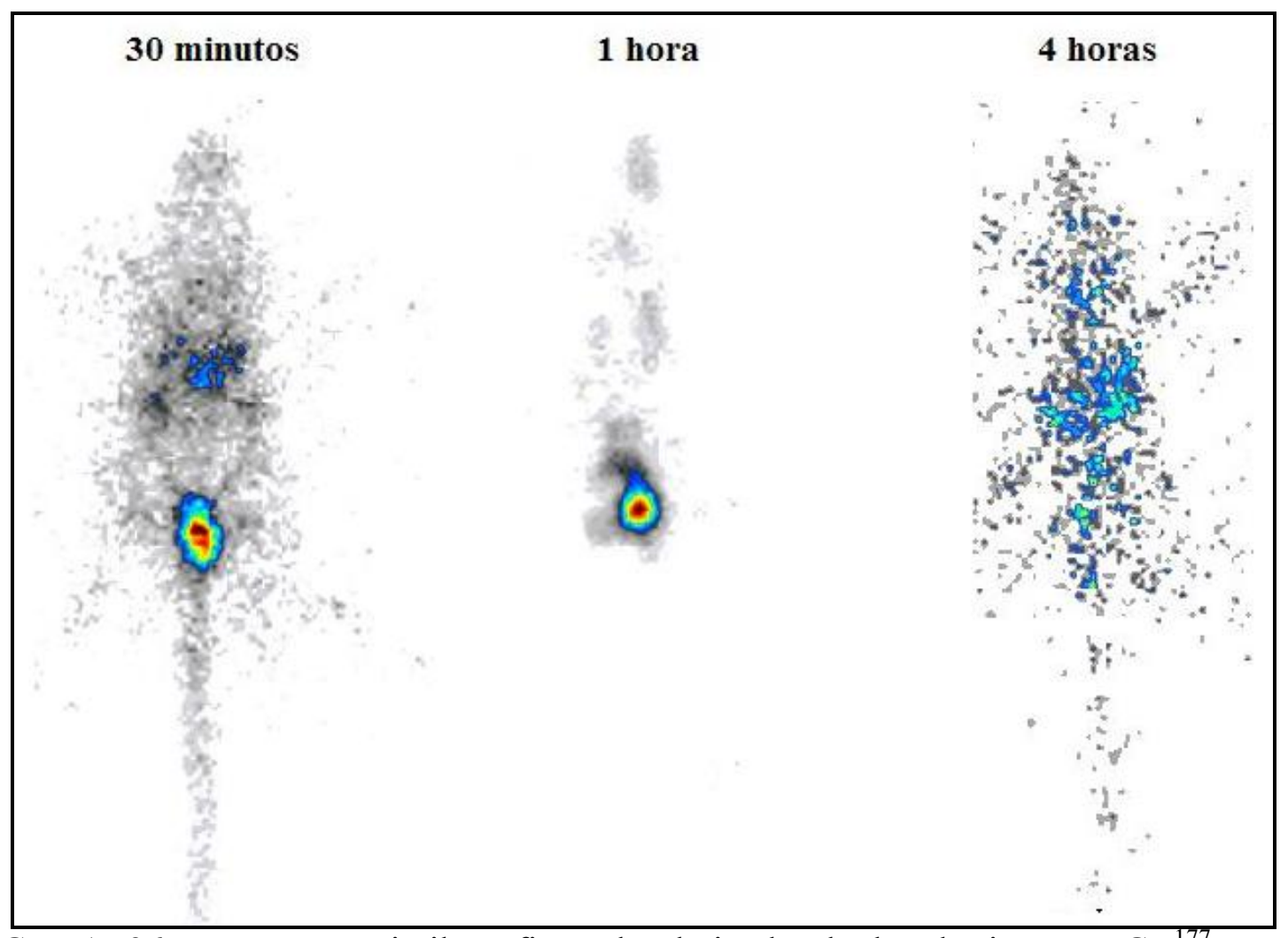

FIGURA 36 - Imagens cintilográficas do derivado da bombesina $\mathrm{BEFG}_{4^{-}}{ }^{177} \mathrm{Lu}$ em camundongos Balb-c machos. 


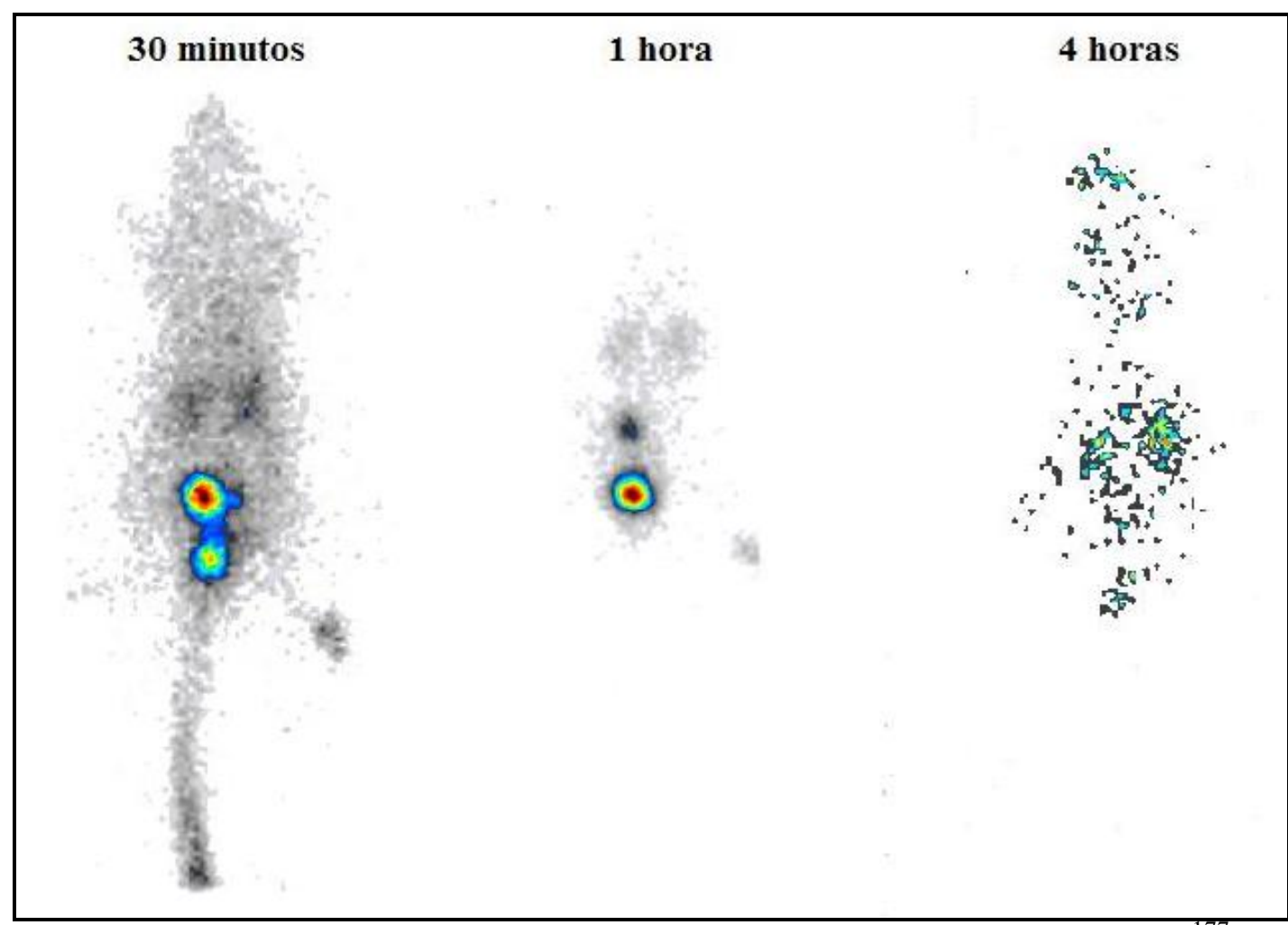

FIGURA 37 - Imagens cintilográficas do derivado da bombesina $\mathrm{BEFG}_{5^{-}}{ }^{177} \mathrm{Lu}$ em camundongos Balb-c machos.

\subsubsection{Estudos de biodistribuição em camundongos Nude com tumor PC-3}

Para avaliar a ligação dos derivados da bombesina radiomarcados com ${ }^{177} \mathrm{Lu}$ às células de tumor de próstata in vivo, desenvolveu-se um modelo animal por meio da inoculação de células PC-3, derivadas de adenocarcinoma de próstata humano, por via subcutânea, no dorso dos camundongos Nude. Ao final de três semanas verificou-se a estrutura morfológica das massas tumorais induzidas, com o auxílio do microscópio óptico, após coloração com hematoxicilina/eosina, com o propósito de certificar se suas particularidades correspondem ao material padrão que lhes deu origem.

Os resultados da análise histológica são mostrados nas FIG. 38, 39 e 40. As fotomicrografias ópticas mostram que o tumor foi bem induzido, ficando restrito à região subcutânea do dorso dos camundongos, envolto por uma cápsula, e apresentando alta celularidade e ausência de infiltrado inflamatório. É possível observar também a presença de vasos sanguíneos entre as células tumorais, responsáveis pela nutrição celular e característicos de formações tumorais malignas, caracterizadas pela angiogênese e metástases. As células tumorais, por sua vez, são pouco diferenciadas e exibem uma forma de crescimento desorganizado. 


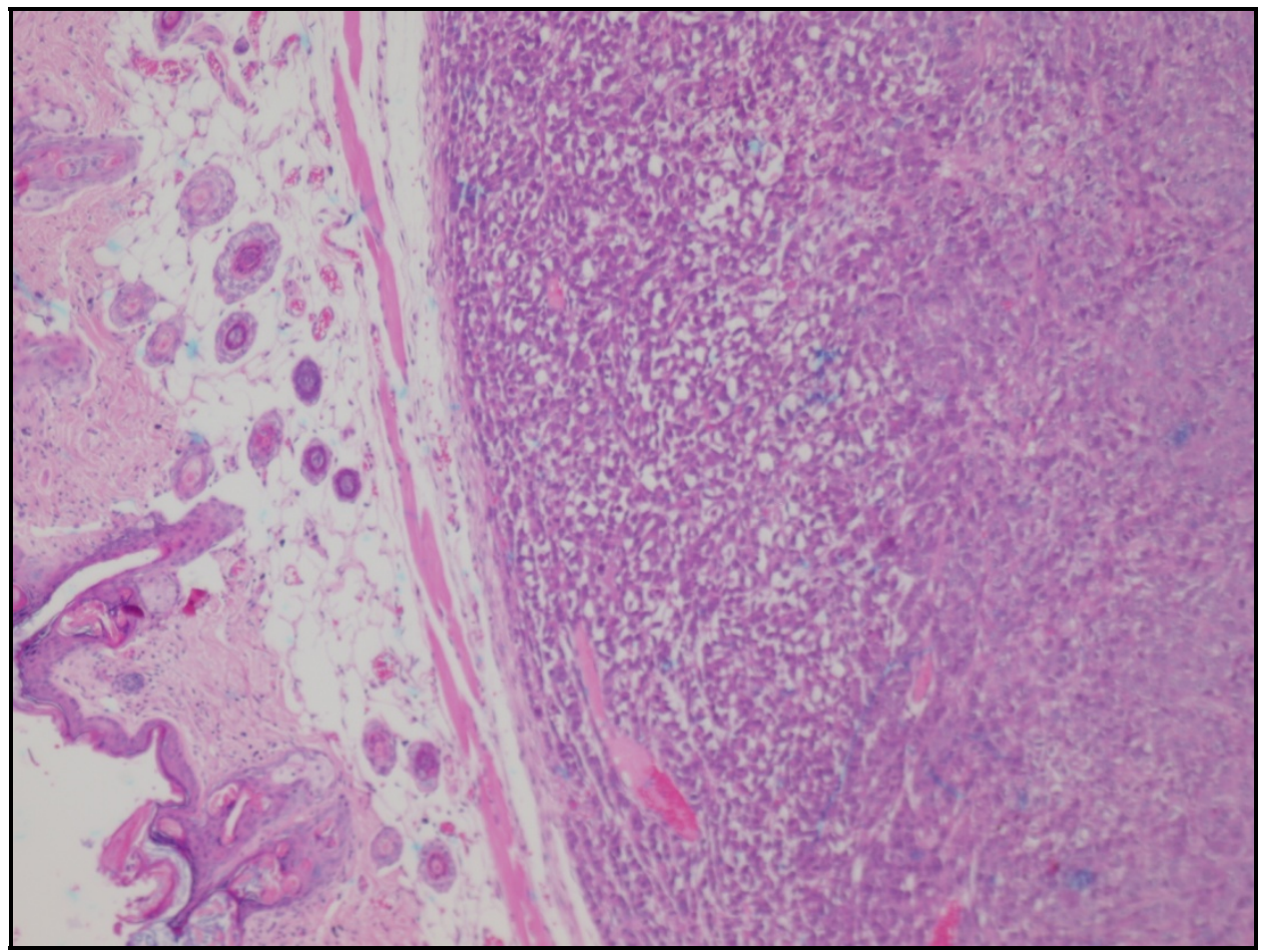

FIGURA 38 - Corte de tumor de células PC-3, induzido em camundongos Nude, mostrando o epitélio, o tecido conjuntivo denso corado em róseo pela eosina e composto por fibras colágenas delicadas e o tecido conjuntivo frouxo, formado pela substância fundamental amorfa, em imagem negativa, e por glândulas ligeiramente basófilas. Logo abaixo, pode-se visualizar a formação tumoral envolta por uma cápsula (Aumento: 100x).

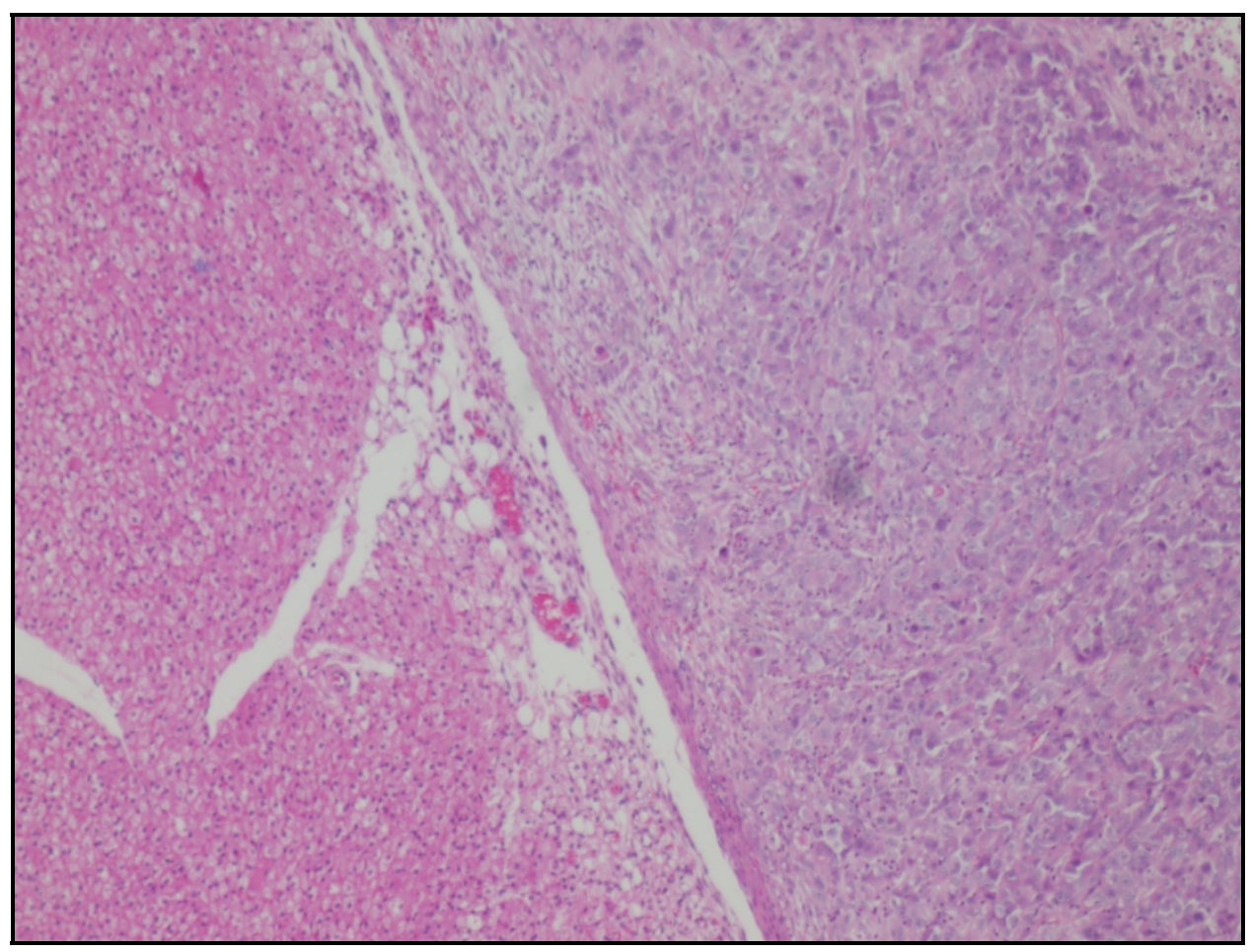

FIGURA 39 - Corte de tumor de células PC-3, mostrando a cápsula acidófila que envolve o tumor, formada por células e fibras colágenas, e as células tumorais, de citoplasma ligeiramente basófilo (Aumento: 400x). 


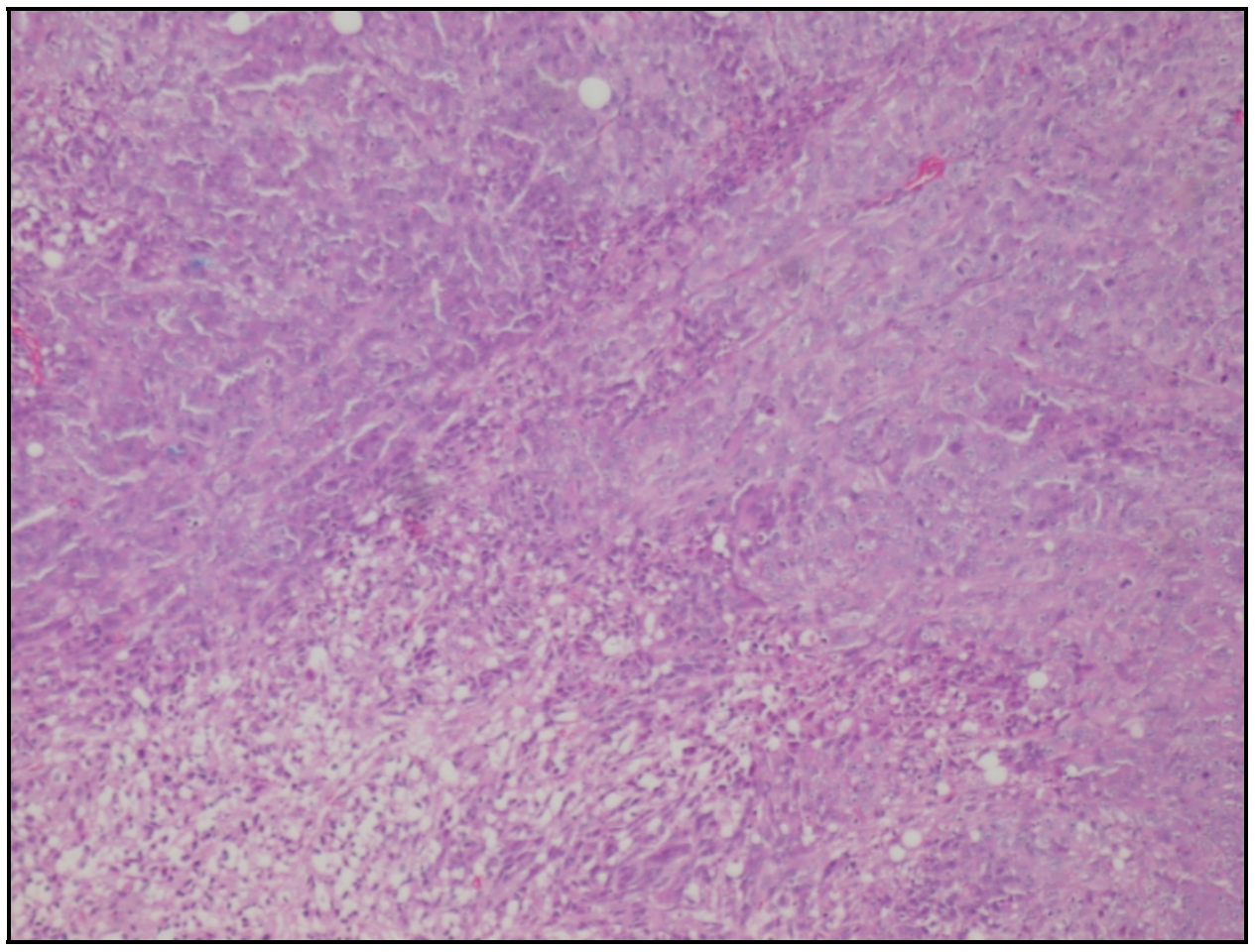

FIGURA 40 - Corte de tumor de células PC-3, mostrando a alta densidade de células pouco diferenciadas, de citoplasma ligeiramente basófilo, sustentadas por tecido conjuntivo (acidófilo) e apresentando crescimento desorganizado (Aumento: 400x).

Os resultados da captação dos derivados $\mathrm{BEFG}_{1}, \mathrm{BEFG}_{2}, \mathrm{BEFG}_{3}, \mathrm{BEFG}_{4} \mathrm{e}$ $\mathrm{BEFG}_{5}$ radiomarcados com lutécio-177 no tumor encontram-se na FIG. 41. Pode-se observar, pelos resultados obtidos, que os dois peptídeos com maior espaçador - $\mathrm{BEFG}_{4}$ ${ }^{177} \mathrm{Lu}$ e $\mathrm{BEFG}_{5^{-}}{ }^{177} \mathrm{Lu}$ - apresentaram maior captação tumoral 1 hora após a administração endovenosa $(p=0,0055)$, quando comparados aos demais derivados estudados. Esses resultados confirmam dados da literatura que afirmam que análogos da bombesina com espaçadores de maior cadeia carbônica apresentam vantagens sobre derivados com espaçadores menores (Varvarigou et al., 2004). A captação dos derivados $\mathrm{BEFG}_{1^{-}}{ }^{177} \mathrm{Lu}$, $\mathrm{BEFG}_{2-}{ }^{177} \mathrm{Lu}, \mathrm{BEFG}_{3}{ }^{-177} \mathrm{Lu}$ pelas células tumorais não foi significativamente diferente na primeira hora após a administração $(\mathrm{p}>0,05)$. A partir de 4 horas após a administração endovenosa, não houve diferença significativa entre a captação tumoral dos derivados em estudo. 


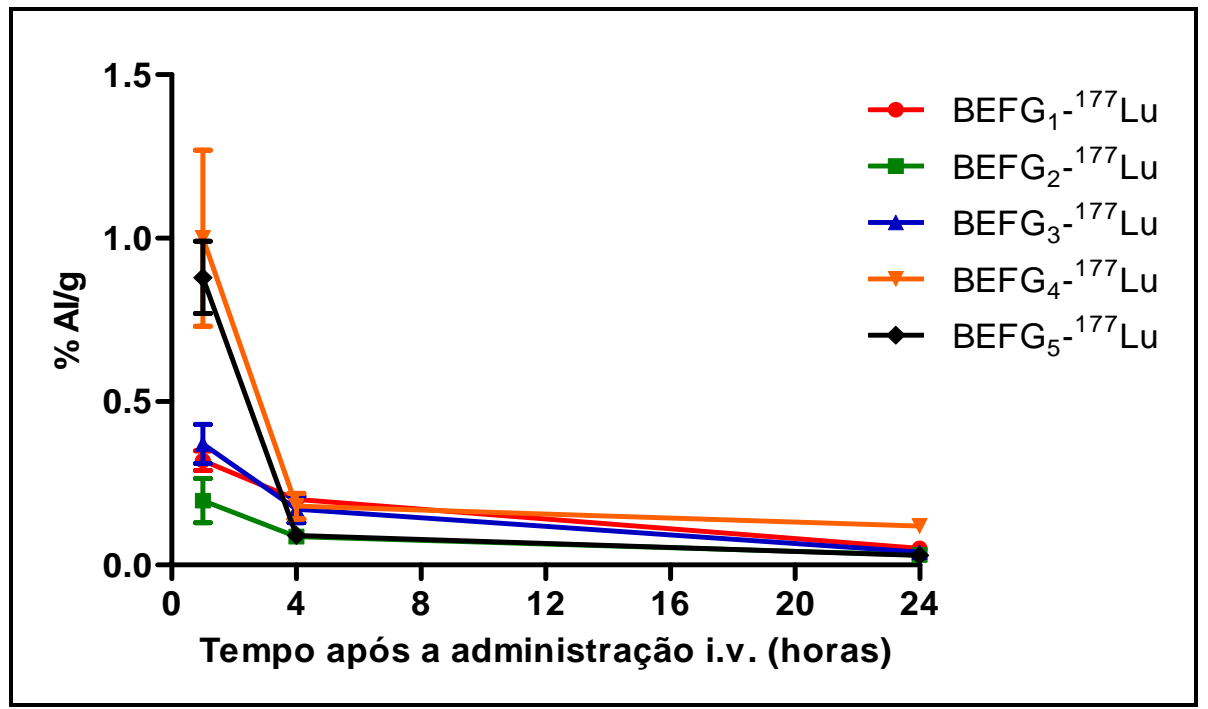

FIGURA 41 - Cinética dos derivados da bombesina radiomarcados com ${ }^{177} \mathrm{Lu}$ em adenocarcinoma de próstata humano (PC-3) implantado em camundongos Nude. Os dados estão expressos em porcentagem da atividade injetada por grama de tumor $(n=3)$.

Os dados contidos na TAB. 16 mostram os valores de porcentagem de atividade injetada por grama de tumor $(\% \mathrm{AI} / \mathrm{g})$ e de porcentagem da atividade total retida no organismo por grama de tumor $(\% \mathrm{ARO} / \mathrm{g})$ em cada tempo para todos os derivados. Os resultados de \% $\mathrm{ARO} / \mathrm{g}$ foram obtidos dividindo-se a \% $\mathrm{AI} / \mathrm{g}$ pela fração retida no organismo em cada tempo, determinada a partir dos estudos de corpo inteiro em camundongos Balb-c (FIG. 32). Os valores mostram que, apesar da baixa captação tumoral observada em função da atividade injetada (FIG. 41), uma porcentagem significativa dos derivados radiomarcados encontra-se retida no tumor até 24 horas após a administração, quando se considera a radioatividade presente no organismo neste tempo.

Os valores de porcentagem da atividade total retida no organismo por grama de tumor permitem predizer a aplicabilidade dos derivados da bombesina para diagnóstico e/ou terapia. Para aplicação no diagnóstico do câncer de próstata, é desejável que o radiofármaco apresente a maior captação tumoral em um curto espaço de tempo, permitindo assim a aquisição de imagens em tempos curtos (Kassis e Adelstein, 2003). Considerando-se essa finalidade, os derivados mais adequados seriam $\mathrm{BEFG}_{4^{-}}{ }^{177} \mathrm{Lu}$ e o $\mathrm{BEFG}_{5}{ }^{-{ }^{177}} \mathrm{Lu}$, os quais apresentaram maior valor de $\% \mathrm{AI} / \mathrm{g}$ e \% ARO/g 1 hora após a administração endovenosa. Para aplicação em terapia radioisotópica do câncer de próstata, deseja-se que o radiofármaco seja retido pelas células tumorais, para que a radiação cause dano às células, provocando morte celular (Kassis e Adelstein, 2003). Nesse caso o derivado mais adequado seria o $\mathrm{BEFG}_{1^{-}}{ }^{177} \mathrm{Lu}$ que, apesar de apresentar valores menores de 
$\% \mathrm{Ai} / \mathrm{g}$ em todos os tempos e \% ARO/g 1 hora após a administração, apresentou maiores valores de \% ARO/g 4 e 24 horas após a administração.

TABELA 16 - Valores de porcentagem de atividade por grama de tumor em função da atividade injetada e da atividade retida no organismo em cada tempo.

\begin{tabular}{|c|c|c|c|c|c|c|}
\hline \multirow{2}{*}{$\begin{array}{l}\text { Derivado da } \\
\text { bombesina }\end{array}$} & \multicolumn{3}{|c|}{$\% \mathrm{AI} / \mathrm{g}$} & \multicolumn{3}{|c|}{$\%$ ARO/g } \\
\hline & 1 hora & 4 horas & 24 horas & 1 hora & 4 horas & 24 horas \\
\hline $\mathrm{BEFG}_{1^{-}}{ }^{177} \mathrm{Lu}$ & $0,32 \pm 0,03$ & $0,20 \pm 0,01$ & $0,05 \pm 0,01$ & $0,84 \pm 0,08$ & $1,92 \pm 0,10$ & $1,00 \pm 0,20$ \\
\hline $\mathrm{BEFG}_{2^{-}}{ }^{177} \mathrm{Lu}$ & $0,20 \pm 0,06$ & $0,09 \pm 0,01$ & $0,03 \pm 0,01$ & $0,43 \pm 0,13$ & $0,49 \pm 0,05$ & $0,25 \pm 0,08$ \\
\hline $\mathrm{BEFG}_{3^{-}}{ }^{177} \mathrm{Lu}$ & $0,37 \pm 0,06$ & $0,17 \pm 0,04$ & $0,04 \pm 0,01$ & $0,96 \pm 0,15$ & $1,31 \pm 0,26$ & $0,47 \pm 0,10$ \\
\hline $\mathrm{BEFG}_{4^{-}}{ }^{177} \mathrm{Lu}$ & $1,00 \pm 0,27$ & $0,18 \pm 0,04$ & $0,12 \pm 0,02$ & $2,00 \pm 0,54$ & $0,66 \pm 0,16$ & $0,92 \pm 0,16$ \\
\hline $\mathrm{BEFG}_{5^{-}}{ }^{177} \mathrm{Lu}$ & $0,88 \pm 0,11$ & $0,09 \pm 0,02$ & $0,03 \pm 0,01$ & $4,38 \pm 0,54$ & $1,51 \pm 0,33$ & $0,65 \pm 0,20$ \\
\hline
\end{tabular}

Radiofármacos para aplicação em terapia radioisotópica são designados para depositar uma dose citotóxica de radiação em sítios patológicos. A radiação provocará a morte das células alvo via dano direto ou indireto e para isso faz-se necessária a retenção do radiofármaco nas células doentes. No entanto, o potencial destrutivo da radiação emitida por radioisótopos aplicados em terapia não está restrito ao sítio patológico, mas também aos tecidos sadios (Chen et al., 2008). No caso dos derivados da bombesina, a seletividade é influenciada pelo grupamento espaçador.

O grande inconveniente da aplicação clínica dos derivados da bombesina descritos pela literatura para diagnóstico e terapia de tumores positivos para GRPr é sua alta captação pancreática, que varia entre $2 \%$ e $60 \%$ da atividade administrada, e intestinal, a qual está compreendida entre $1 \%$ e $25 \%$ da atividade injetada, especialmente na primeira hora após a administração (Hu et al., 2002; Zhang et al., 2004; Stangelberger et al., 2005; Johnson et al., 2006; Lantry et al., 2006; Prasanphanic et al., 2007; Zhang et al., 2007; Lane et al., 2008). Apesar dos GRPr serem encontrados em alta densidade no pâncreas de camundongos, mas não de humanos, esses receptores são identificados em $100 \%$ dos cortes histológicos de cólon humano (Waser et al., 2007), sugerindo que altas doses de radiação absorvidas por esse tecido podem acarretar efeitos adversos irreversíveis ao paciente. Observa-se, pelos resultados mostrados nas FIG. 42 e 43, que os derivados em estudo apresentam baixo acúmulo na região abdominal, principalmente no pâncreas e no intestino, respectivamente. Portanto, apesar da captação tumoral ser menor em relação a alguns dos derivados da bombesina já descritos (Lantry et al., 2006; Zhang et al., 2007), 
$\mathrm{BEFG}_{1^{-}}{ }^{177} \mathrm{Lu}, \mathrm{BEFG}_{2^{-}}{ }^{177} \mathrm{Lu}, \mathrm{BEFG}_{3^{-}}{ }^{177} \mathrm{Lu}, \mathrm{BEFG}_{4^{-}}{ }^{177} \mathrm{Lu}$ e $\mathrm{BEFG}_{5^{-}}{ }^{177} \mathrm{Lu}$ apresentam a vantagem da baixa captação pelos tecidos sadios. Esses resultados confirmam dados da literatura consultada, os quais mostram que não há relação linear entre captação intestinal ou pancreática e tumoral. Os derivados radiomarcados apresentaram baixa captação nesses tecidos e significativa captação tumoral, ao contrário de alguns derivados descritos na literatura, os quais apresentaram alta captação nesses dois tecidos e captação tumoral menor do que os derivados em estudo (La Bella et al., 2002; Lane et al., 2008).

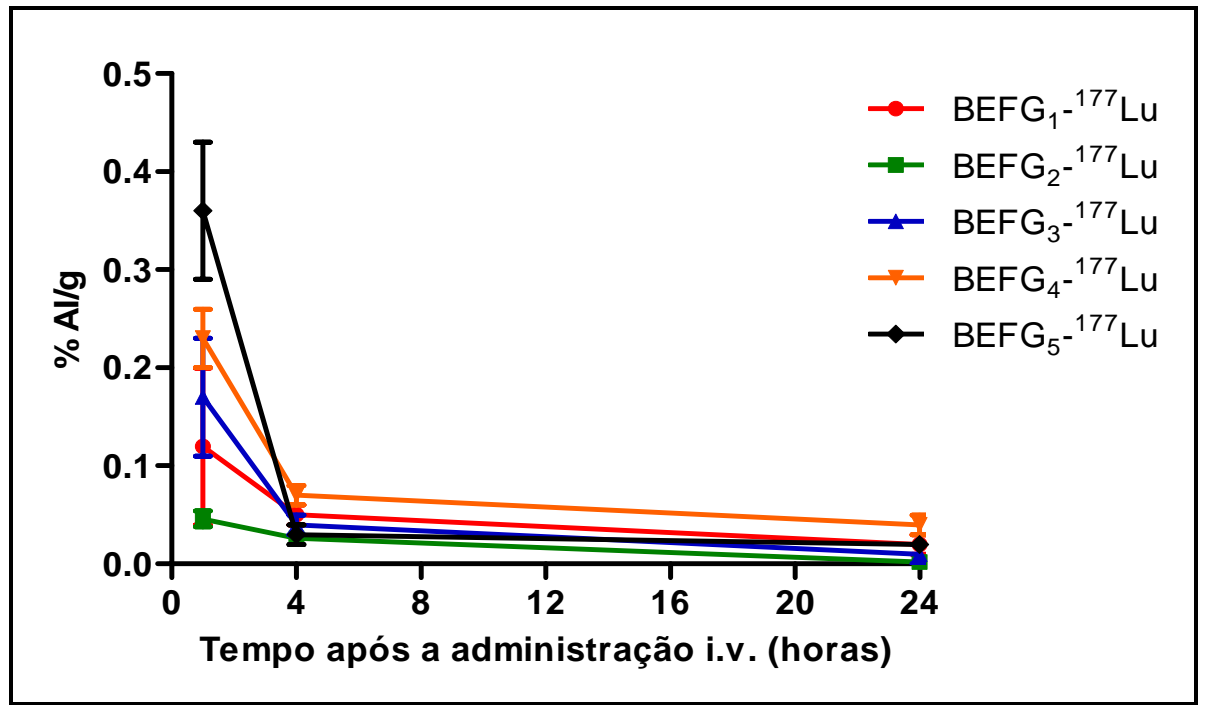

FIGURA 42 - Cinética dos derivados da bombesina radiomarcados com ${ }^{177}$ Lu no pâncreas de camundongos Nude com tumor PC-3 ( $\mathrm{n}=3$ ). Os dados estão expressos em porcentagem da atividade injetada por grama de tecido.

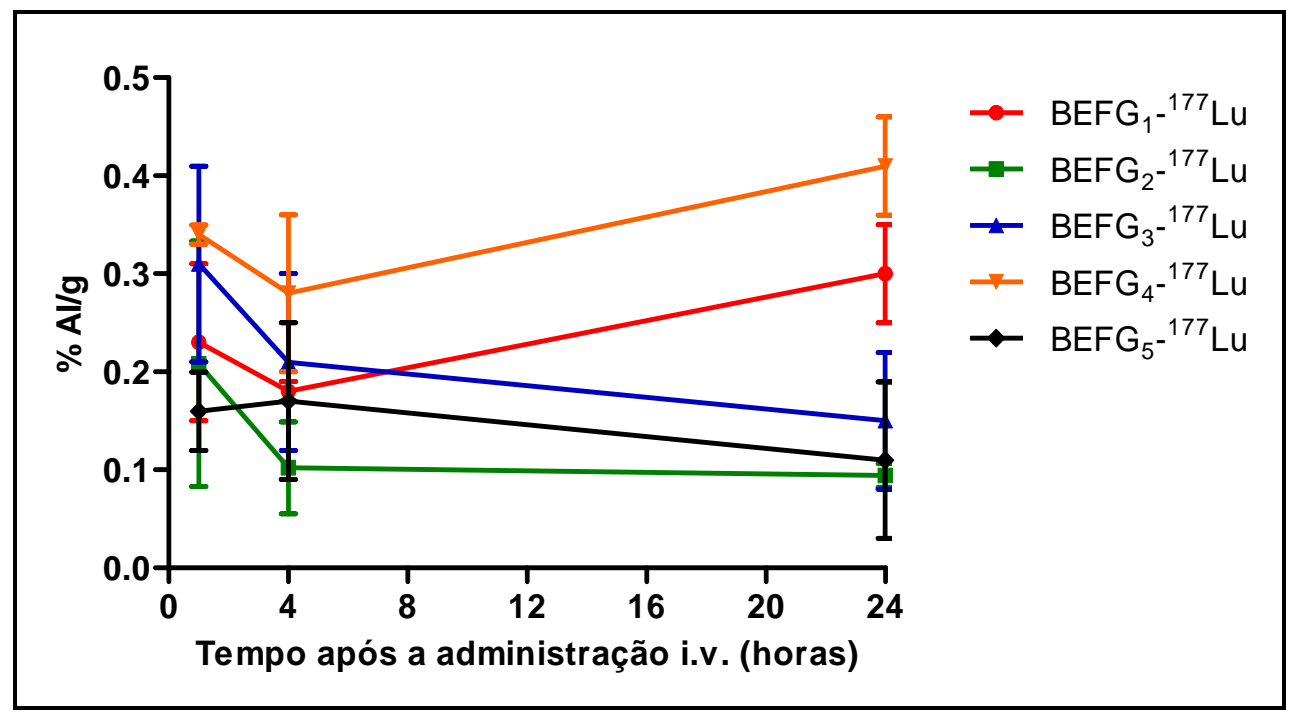

FIGURA 43 - Cinética dos derivados da bombesina radiomarcados com ${ }^{177} \mathrm{Lu}$ nos intestinos (com conteúdo) de camundongos Nude com tumor PC-3 $(n=3)$. Os dados estão expressos em porcentagem da atividade injetada por grama de tecido. 
Apesar da baixa captação abdominal, é possível observar uma relação entre a estrutura dos derivados da bombesina estudados e sua discreta captação no pâncreas, tecido que expressa receptores GRP em alta densidade em camundongos. Os derivados com maior espaçador e com maior captação tumoral - $\mathrm{BEFG}_{4^{-}}{ }^{177} \mathrm{Lu}$ e $\mathrm{BEFG}_{5^{-}}{ }^{177} \mathrm{Lu}$ - são também os que apresentam maior captação pancreática. Essa relação não foi observada nos intestinos, provavelmente devido à influência da excreção intestinal na captação tardia observada nesse tecido. A captação intestinal tardia pode ser decorrente do metabolismo hepático dos derivados e de sua transferência via bile para o intestino, bem como ser oriunda do estômago, da corrente sanguínea ou mesmo dos rins, resultante do processo de reabsorção.

Os estudos de biodistribuição em camundongos Nude com tumor PC-3 confirmaram o rápido clareamento sanguíneo e a excreção renal previamente descrita nos estudos feitos em camundongos Balb-c que receberam os mesmos derivados por via endovenosa (FIG. 44 e 45, respectivamente). Entretanto, a captação renal e a atividade no sangue dos derivados radiomarcados em camundongos Nude com tumor de próstata humano foi em média maior do que a observada em camundongos Balb-c. Mais uma vez, não foi possível estabelecer uma relação entre a lipossolubilidade dos derivados da bombesina e sua captação renal.

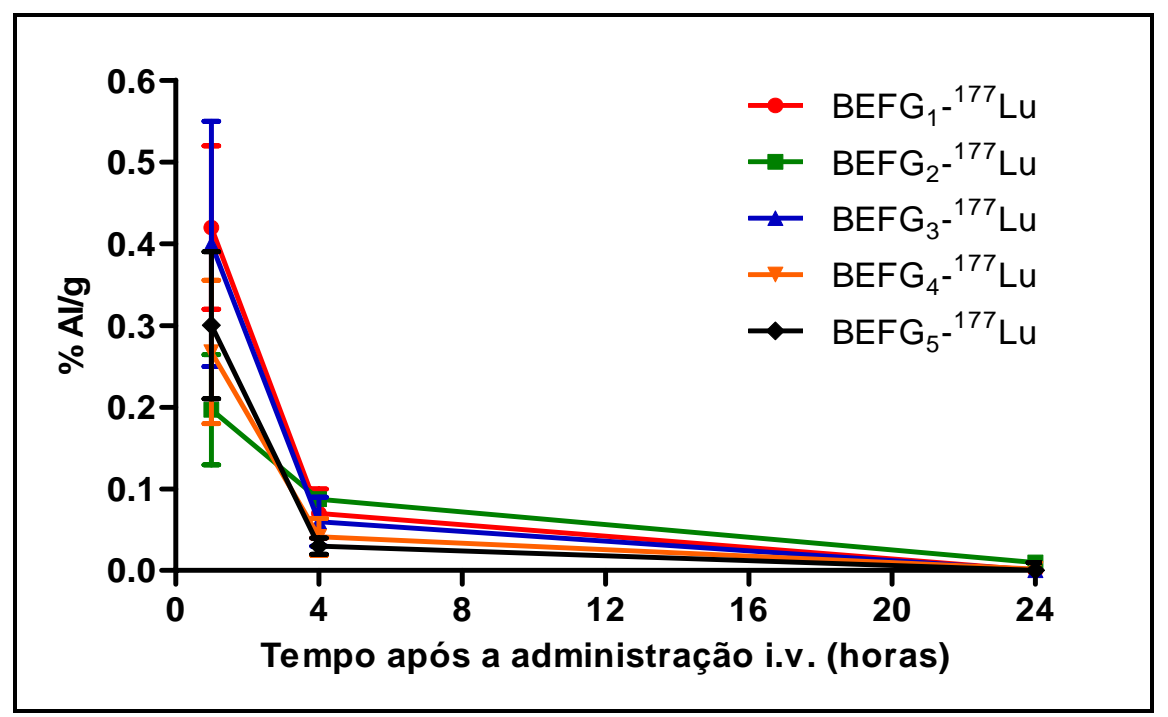

FIGURA 44 - Cinética sanguínea dos derivados da bombesina radiomarcados com ${ }^{177} \mathrm{Lu}$ em camundongos Nude com tumor PC-3 $(\mathrm{n}=3)$. Os dados estão expressos em porcentagem da atividade injetada por mililitro de sangue. 


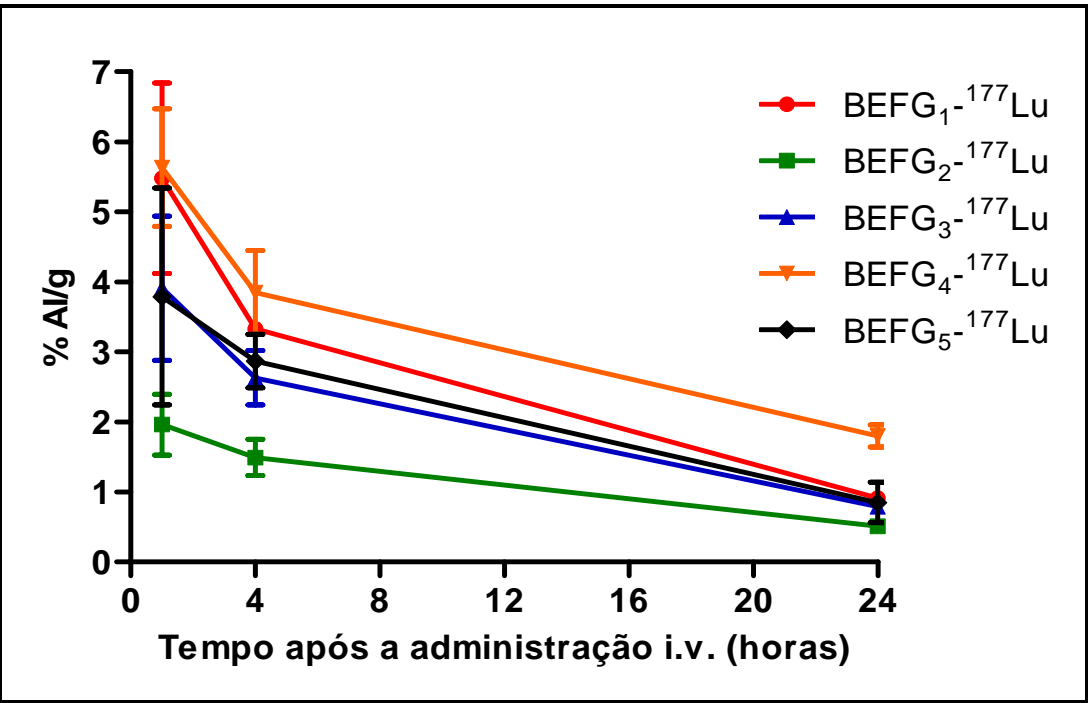

FIGURA 45 - Cinética dos derivados da bombesina radiomarcados com ${ }^{177} \mathrm{Lu}$ nos rins de camundongos Nude com tumor PC-3 ( $\mathrm{n}=3)$. Os dados estão expressos em porcentagem da atividade injetada por grama de tecido.

A baixa lipossolubilidade dos derivados em estudo foi mais uma vez confirmada por sua baixa captação hepática, evidenciada também nos camundongos Nude (FIG. 46).

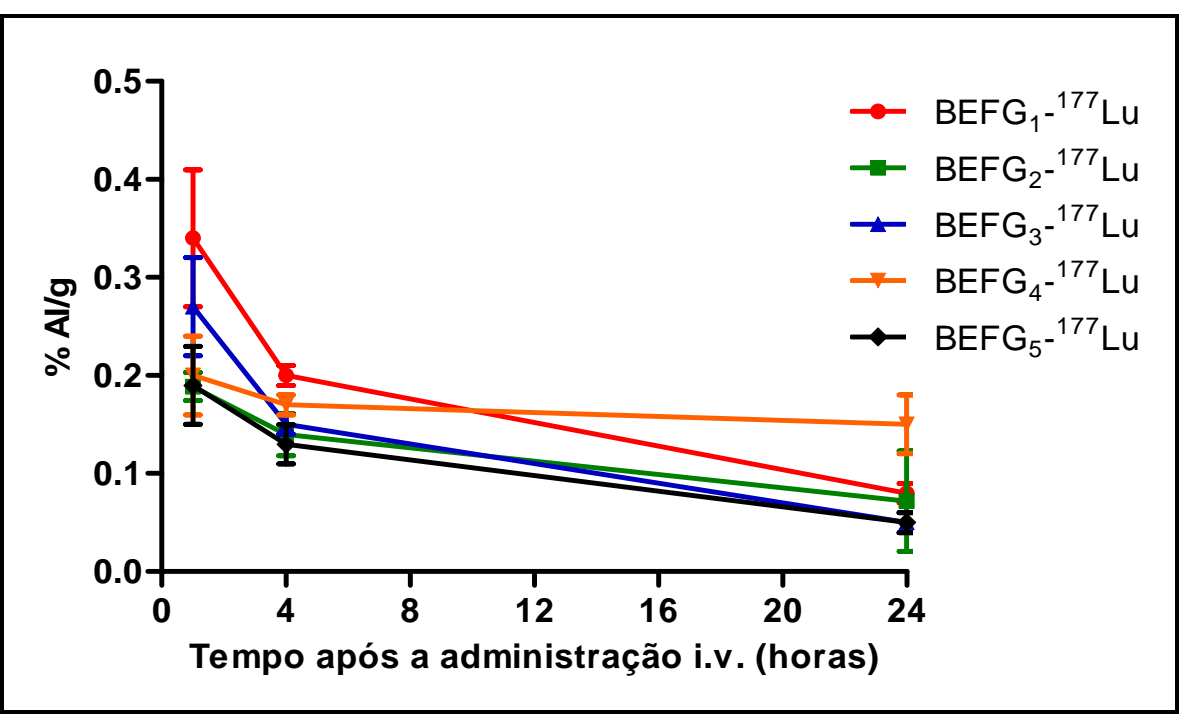

FIGURA 46 - Cinética dos derivados da bombesina radiomarcados com ${ }^{177}$ Lu no fígado de camundongos Nude com tumor PC-3 ( $\mathrm{n}=3$ ). Os dados estão expressos em porcentagem da atividade injetada por grama de tecido.

A baixa captação óssea (FIG. 47) dos derivados radiomarcados, também observada nos bioensaios em camundongos Nude com tumor, confirmou a ausência de contaminação por cloreto de lutécio livre nas preparações, conforme demonstrado por 
cromatografia em camada delgada, sempre realizada previamente à administração, e também a estabilidade dos derivados in vivo frente à descomplexação do lutécio-177. Entertanto, apesar de a captação óssea ser pequena, ela deve ser analisada futuramente em estudos dosimétricos, dada a radiossensibilidade da medula óssea.

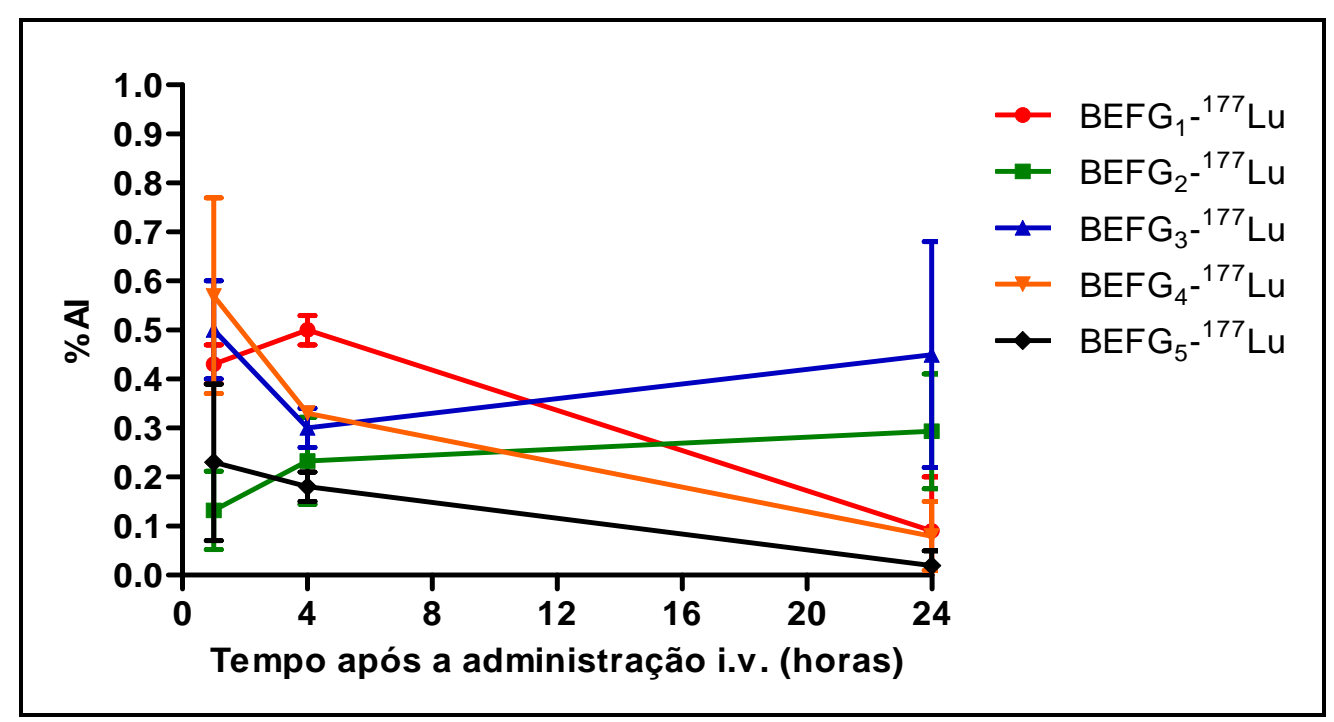

FIGURA 47 - Captação óssea dos derivados da bombesina radiomarcados com ${ }^{177} \mathrm{Lu} \mathrm{em}$ camundongos Nude com tumor PC-3 ( $\mathrm{n}=3)$. Os dados estão expressos em porcentagem da atividade injetada no osso total.

A baixa captação dos derivados na próstata (FIG. 48) confirmou os dados da literatura de que a próstata normal ou hiperplásica é negativa para os receptores GRP (Lantry et al., 2006; Waser et al., 2007). Esse achado permite a aplicação dos derivados da bombesina não apenas no diagnóstico e terapia de tumores de próstata metastáticos, mas também no diagnóstico diferencial entre o adenocarcinoma prostático e as demais patologias que acometem a próstata, tais como hiperplasia e tumores benignos. 


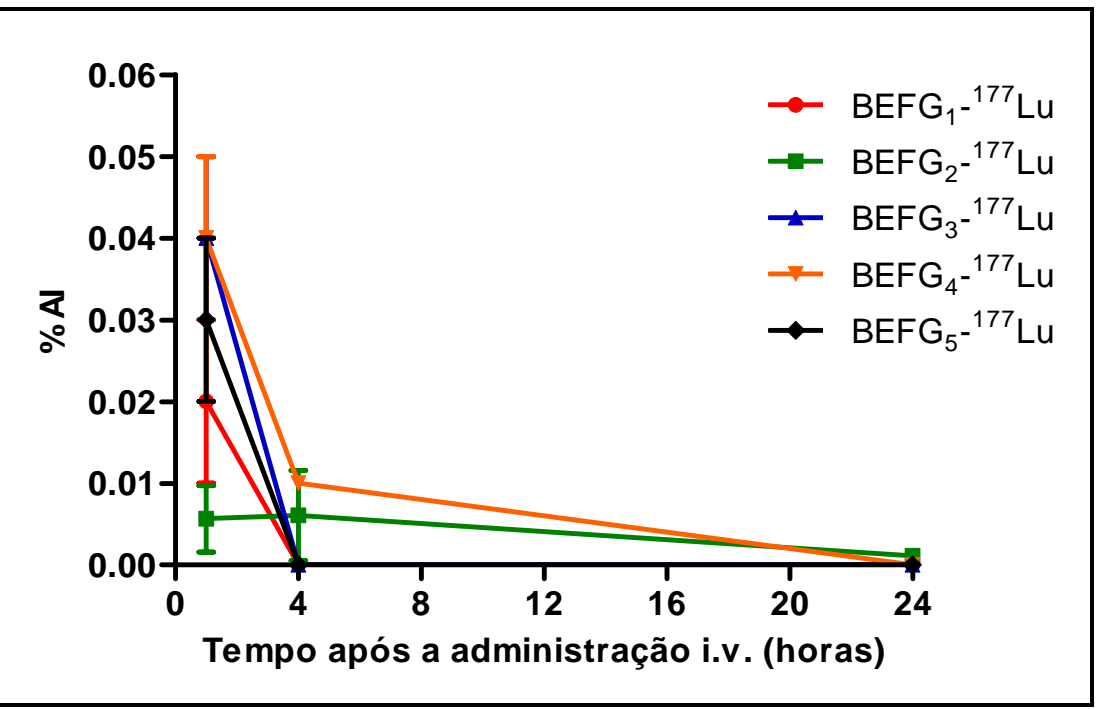

FIGURA 48 - Cinética dos derivados da bombesina radiomarcados com ${ }^{177} \mathrm{Lu}$ na próstata de camundongos Nude com tumor PC-3 ( $\mathrm{n}=3)$. Os dados estão expressos em porcentagem da atividade injetada na próstata.

A captação dos derivados da bombesina radiomarcados com lutécio-177 no coração, nos pulmões, no estômago vazio, no baço e no músculo dos camundongos Nude com tumor PC-3 é ilustrada nas FIG. 49, 50, 51, 52 e 53, respectivamente.

A captação no coração (FIG. 49) e nos pulmões (FIG. 50) provavelmente decorre do aporte sanguíneo nestes órgãos. Isso pode ser observado pela similaridade entre os traçados das curvas de decaimento radioativo dos produtos administrados, bem como em seus níveis de grandeza.

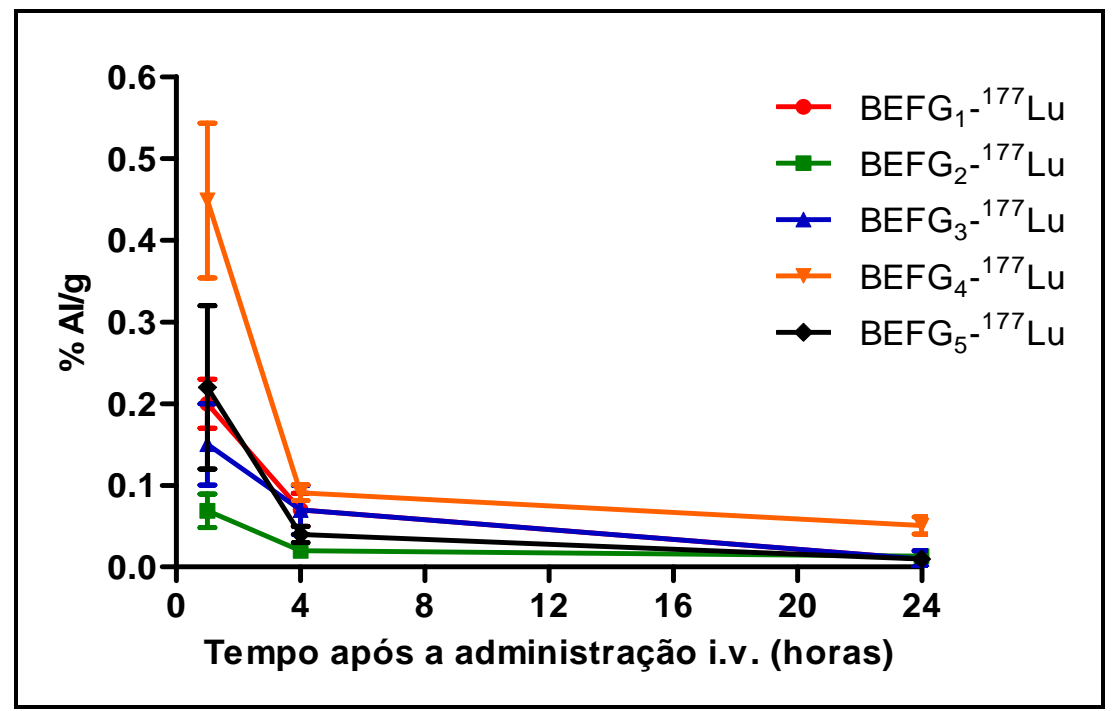

FIGURA 49 - Cinética dos derivados da bombesina radiomarcados com ${ }^{177}$ Lu no coração de camundongos Nude com tumor PC-3 $(n=3)$. Os dados estão expressos em porcentagem da atividade injetada por grama de tecido. 


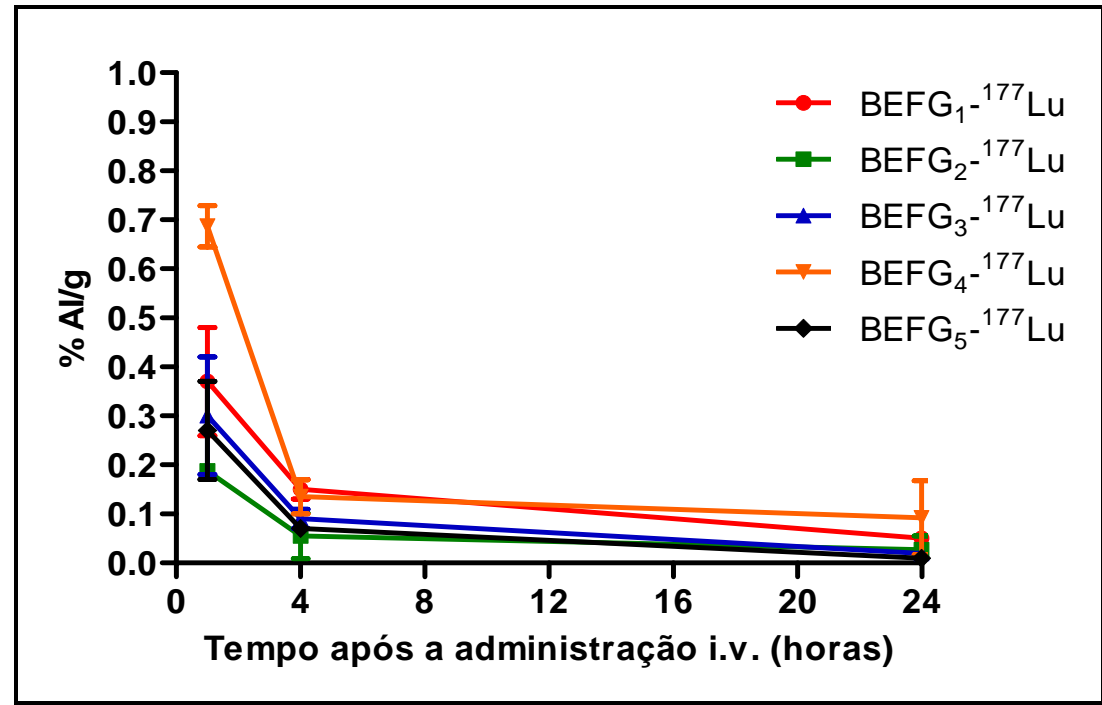

FIGURA 50 - Cinética dos derivados da bombesina radiomarcados com ${ }^{177} \mathrm{Lu}$ nos pulmões de camundongos Nude com tumor PC-3 $(\mathrm{n}=3)$. Os dados estão expressos em porcentagem da atividade injetada por grama de tecido.

Os resultados de captação dos derivados da bombesina radiomarcados no estômago (FIG. 51), baço (FIG. 52) e músculo esquelético (FIG. 53) dos camundongos Nude foram semelhantes aos encontrados nos estudos de biodistribuição com camundongos Balb-c.

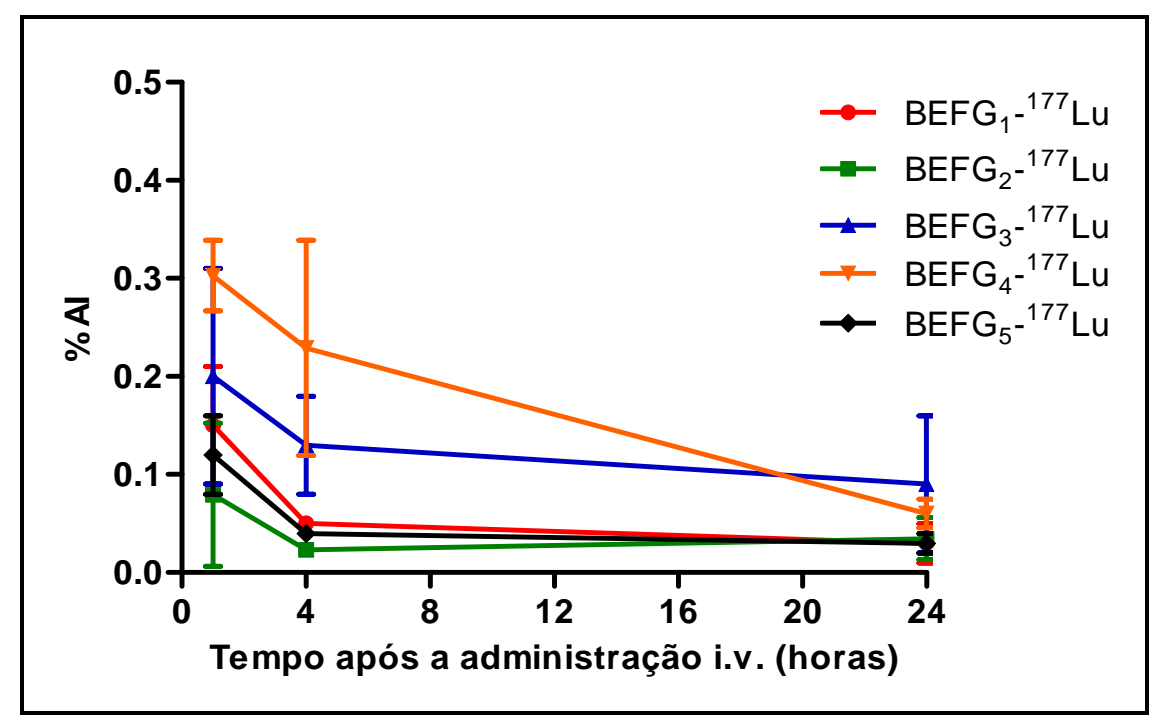

FIGURA 51 - Cinética dos derivados da bombesina radiomarcados com ${ }^{177} \mathrm{Lu}$ no estômago de camundongos Nude com tumor PC-3 $(\mathrm{n}=3)$. Os dados estão expressos em porcentagem da atividade injetada por grama de tecido. 


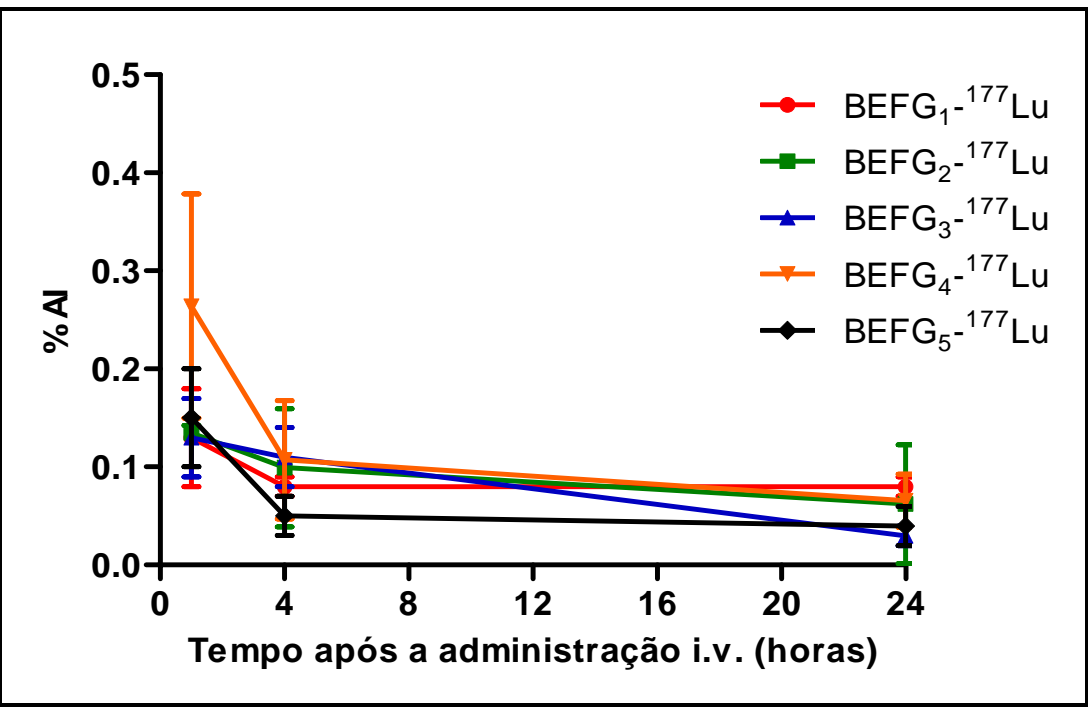

FIGURA 52 - Cinética dos derivados da bombesina radiomarcados com ${ }^{177} \mathrm{Lu}$ no baço de camundongos Nude com tumor PC-3 ( $\mathrm{n}=3)$. Os dados estão expressos em porcentagem da atividade injetada por grama de tecido.

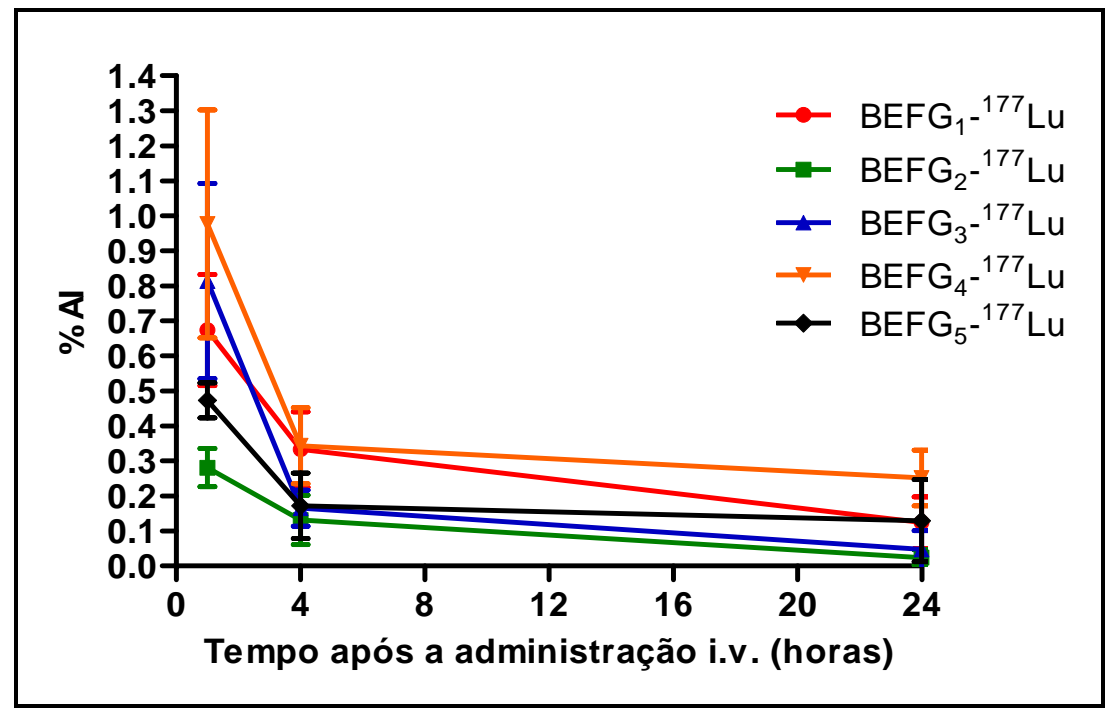

FIGURA 53 - Cinética dos derivados da bombesina radiomarcados com ${ }^{177} \mathrm{Lu}$ no músculo de camundongos Nude com tumor PC-3 ( $\mathrm{n}=3$ ). Os dados estão expressos em porcentagem da atividade injetada no músculo total.

Os dados de porcentagem de atividade injetada por grama de tecido foram utilizados para calcular as razões entre captação tumoral, os órgãos excretores (rins e intestinos) e o pâncreas, órgão que comumente expressam receptores para GRP. Os resultados são mostrados na TAB. 17. 
TABELA 17 - Razões tumor:tecidos calculadas para os diferentes derivados da bombesina estudados. Os valores utilizados para os cálculos foram os \% $\mathrm{AI} / \mathrm{g}$ obtidos a partir da biodistribuição dos derivados em camundongos Nude implantados com células PC-3.

\begin{tabular}{|c|c|c|c|c|c|c|c|c|c|c|c|c|}
\hline Razão & \multicolumn{3}{|c|}{ Tumor:Sangue } & \multicolumn{3}{|c|}{ Tumor:Rins } & \multicolumn{3}{|c|}{ Tumor:Intestinos } & \multicolumn{3}{|c|}{ Tumor:Pâncreas } \\
\hline $\begin{array}{c}\text { Tempo } \\
\text { após a } \\
\text { injeção (h) }\end{array}$ & 1 & 4 & 24 & 1 & 4 & 24 & 1 & 4 & 24 & 1 & 4 & 24 \\
\hline$\underset{{ }^{177} \mathrm{Lu}}{\mathrm{BEF}_{1^{-}}}$ & 0,75 & 2,74 & 13,9 & 0,06 & 0,06 & 0,06 & 1,4 & 1,09 & 0,13 & 2,64 & 4,36 & 2,93 \\
\hline $\begin{array}{c}\mathrm{BEFG}_{2-} \\
{ }^{177} \mathrm{Lu}\end{array}$ & 3,14 & 3,69 & 3,21 & 0,10 & 0,06 & 0,06 & 0,94 & 0,86 & 0,33 & 4,31 & 3,34 & 1,46 \\
\hline$\underset{{ }^{177} \mathrm{Lu}}{\mathrm{BEFG}_{3}-}$ & 0,93 & 2,85 & 21,28 & 0,1 & 0,07 & 0,05 & 1,19 & 0,85 & 0,27 & 2,15 & 4,76 & 3,26 \\
\hline$\underset{\mathrm{BEFG}_{4-}}{{ }^{177} \mathrm{Lu}}$ & 3,76 & 4,41 & 74,32 & 0,18 & 0,05 & 0,07 & 2,91 & 0,64 & 0,29 & 4,29 & 2,70 & 3,06 \\
\hline $\begin{array}{c}\mathrm{BEFG}_{5-} \\
{ }^{177} \mathrm{Lu}\end{array}$ & 2,99 & 2,69 & 6,91 & 0,23 & 0,04 & 0,03 & 5,44 & 0,54 & 0,28 & 2,74 & 2,47 & 1,89 \\
\hline
\end{tabular}

O aumento do valor da razão tumor:sangue no decorrer do tempo sugere que a captação tumoral não se deve ao aporte sanguíneo do tumor, mas sim à sua ligação aos receptores nas células PC-3, exceto para o derivado $\mathrm{BEFG}_{2^{-}}{ }^{177} \mathrm{Lu}$. A razão praticamente constante para esse derivado pode ser indicativa de inespecificidade de ligação.

A razão tumor:rins praticamente constante confirma que a excreção dos peptídeos é realizada principalmente por via renal. A razão tumor:intestinos decrescente sugere excreção também por via gastrointestinal, principalmente nos tempos tardios, ou seja, 4 e 24 horas.

A razão tumor:pâncreas sempre maior do que 1 indica o baixo acúmulo dos derivados da bombesina nesse órgão e, uma provável, maior afinidade pelos receptores presentes nas células tumorais. Esse baixo acúmulo pancreático é a principal diferença entre os derivados estudados neste trabalho e os descritos na literatura, os quais apresentam captação pancreática entre $2 \%$ e $60 \%$ da atividade total injetada na primeira hora após a administração (Hu et al., 2002; Zhang et al., 2004; Stangelberger et al., 2005; Johnson et al., 2006; Lantry et al., 2006; Prasanphanic et al., 2007; Zhang et al., 2007; Lane et al., 2008; Garrison, 2008), e provavelmente também demonstra melhor aplicabilidade clínica. Apesar de, como já mencionado anteriormente, dados da literatura consultada indicarem que não há relação linear entre captação pancreática e tumoral (La Bella et al., 2002; Lane 
et al., 2008) e de as razões tumor:sangue sugerirem que a presença dos radiofármacos no tumor não decorre do aporte sanguíneo, fez-se necessário o desenvolvimento de estudos adicionais para avaliar a especificidade da ligação desses novos derivados da bombesina radiomarcados às células de tumor de próstata. Para tal, realizaram-se os estudos de competição in vivo.

\subsubsection{Estudos de competição em camundongos Nude com tumor PC-3}

Os estudos de competição foram realizados com os derivados que apresentaram maior captação tumoral nos estudos de biodistribuição, ou seja, com o $\mathrm{BEFG}_{4^{-}}{ }^{177} \mathrm{Lu}$ e o $\mathrm{BEFG}_{5^{-}}{ }^{177} \mathrm{Lu}$. Analisou-se a biodistribuição em 1 hora dos dois derivados radiomarcados, administrados 15 ou 45 minutos após uma pré-injeção do respectivo derivado não radiomarcado $(100 \mu \mathrm{g})$ por via endovenosa caudal para atuar como um bloqueador dos receptores (Biddlecombe et al., 2007). Os resultados desses estudos de competição são mostrados nas FIG. 54 e 55.

Pode-se observar que a pré-administração dos derivados não radiomarcados reduziu significativamente a captação tumoral dos respectivos derivados radiomarcados com lutécio-177 ( $\mathrm{p}=0,011$ ), mas não a sua captação nos demais tecidos analisados. Esses resultados sugerem que a ligação dos derivados da bombesina em estudo aos receptores presentes nas células tumorais é específica.

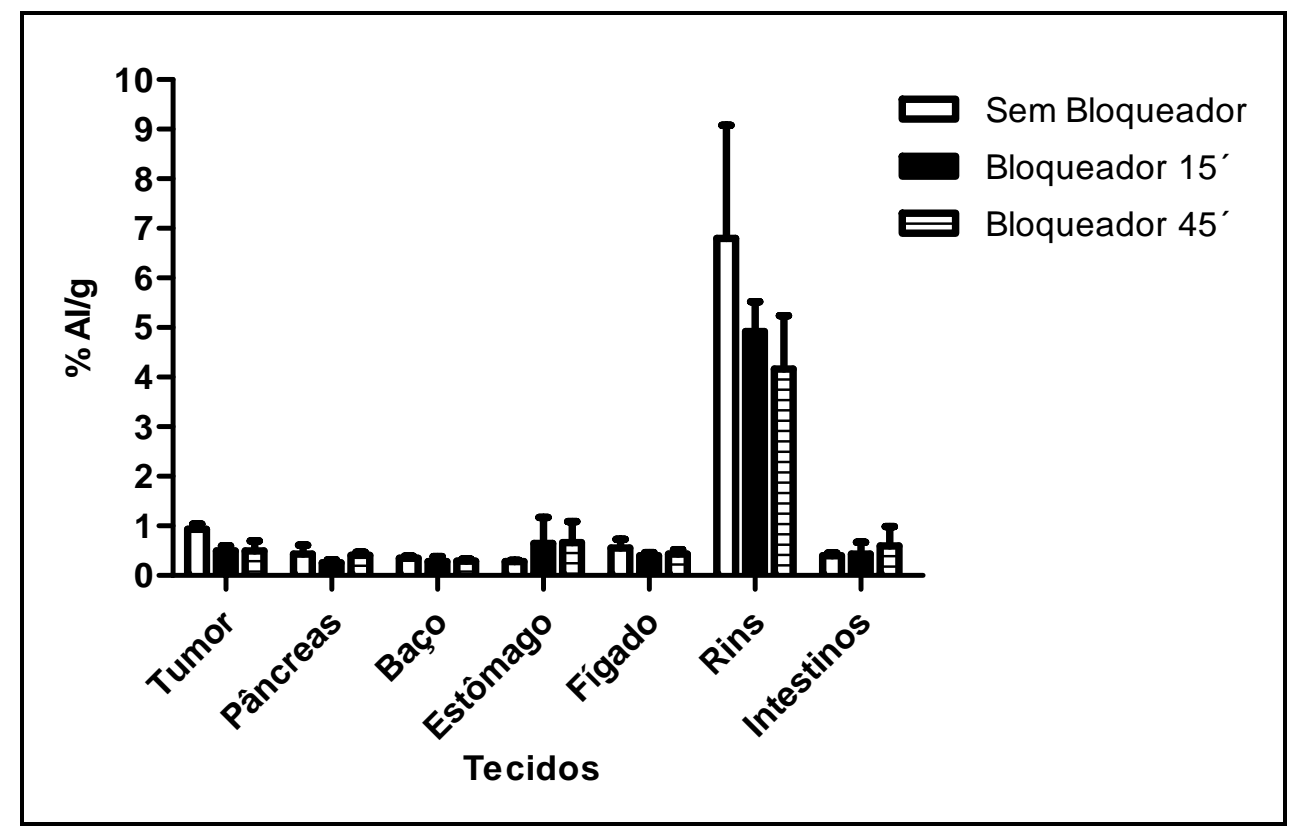

FIGURA 54 - Captação do $\mathrm{BEFG}_{4^{-}}{ }^{177} \mathrm{Lu}$ no tumor de células PC-3 e em alguns tecidos na ausência e na presença do bloqueador $\left(100 \mu \mathrm{g}\right.$ de $\left.\mathrm{BEFG}_{4}\right)$. 


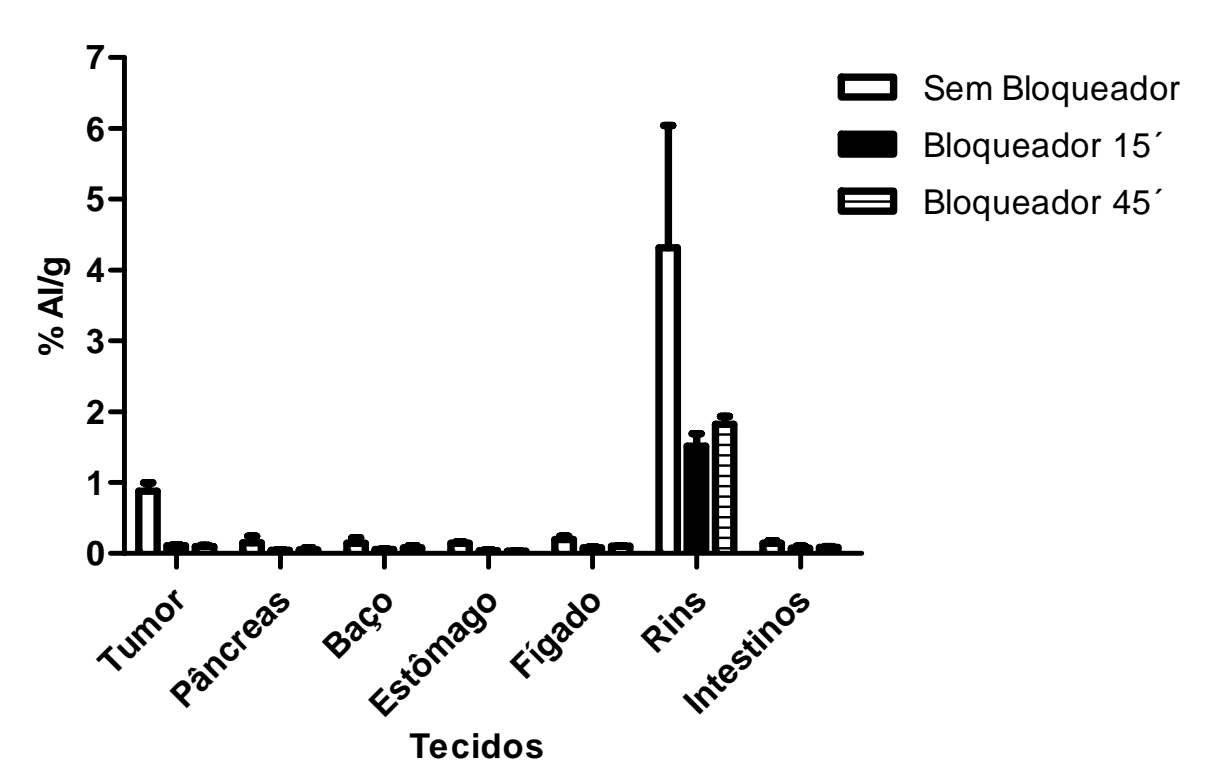

FIGURA 55 - Captação do $\mathrm{BEFG}_{5^{-}}{ }^{177} \mathrm{Lu}$ no tumor de células PC-3 e em alguns tecidos na ausência e na presença do bloqueador $\left(100 \mu \mathrm{g}\right.$ de $\left.\mathrm{BEFG}_{5}\right)$.

A redução da captação renal dos derivados radiomarcados, especialmente do $\mathrm{BEFG}_{5^{-}}{ }^{177} \mathrm{Lu}$, após a pré-administração dos derivados não radiomarcados sugere que, apesar da inespecificidade do mecanismo de excreção de derivados da bombesina (Gotthardt e colaboradores, 2007), pode haver saturação das proteínas transportadoras responsáveis pela secreção tubular. A inobservância de efeito bloqueador observada no pâncreas, órgão que expressa receptores para GRP em alta densidade em camundongos, pode ser decorrente da baixa captação nesse órgão, mesmo na ausência do bloqueador. Já a ausência de efeito bloqueador dos derivados da bombesina não radiomarcados nos demais tecidos sugere captação inespecífica, provavelmente decorrente do aporte sanguíneo nesses tecidos.

Os valores de captação tumoral do $\mathrm{BEFG}_{4^{-}}{ }^{177} \mathrm{Lu}$ e do $\mathrm{BEFG}_{5^{-}}{ }^{177} \mathrm{Lu}$ na ausência e na presença do bloqueador são mostrados na TAB. 18. A pré-administração do $\mathrm{BEFG}_{4}$ reduziu em aproximadamente $47 \%$ a ligação do $\mathrm{BEFG}_{4}{ }^{-177} \mathrm{Lu}$ às células tumorais, 1 hora após a injeção do radiofármaco. Essa redução não variou com o tempo decorrido após a pré-administração, sugerindo, além de especificidade, estabilidade de ligação desse derivado às células tumorais. Já a pré-administração de $\mathrm{BEFG}_{5}$ reduziu em aproximadamente $88 \%$ a ligação do derivado radiomarcado às células tumorais e, a exemplo do observado para o $\mathrm{BEFG}_{4}$, essa redução não variou com o tempo decorrido após a pré-administração. 
A maior redução da ligação do $\mathrm{BEFG}_{5^{-}}{ }^{177} \mathrm{Lu}$ às células tumorais após a préadministração do derivado não radiomarcado, em relação à redução observada para o $\mathrm{BEFG}_{4}{ }^{1}{ }^{177} \mathrm{Lu}$, sugere que, apesar da adição de um aminoácido glicina ao espaçador não alterar significativamente a captação tumoral e a estabilidade da ligação aos receptores, ela pode influenciar positivamente na especificidade dessa ligação, provavelmente favorecendo a interação radiofármaco-receptor.

TABELA 18 - Captação tumoral, em \% AI/g, após uma hora da administração dos derivados da bombesina radiomarcados na ausência e presença do respectivo derivado não radiomarcado (bloqueador).

\begin{tabular}{ccc}
\hline Derivado da Bombesina & BEFG $_{\mathbf{4}^{-}}{ }^{177} \mathbf{L u}$ & BEFG $_{\mathbf{5}^{-}}{ }^{177} \mathbf{L u}$ \\
\hline Sem bloqueador & $0,93 \pm 0,10$ & $0,88 \pm 0,11$ \\
Bloqueador 15' & $0,50 \pm 0,10$ & $0,11 \pm 0,01$ \\
Bloqueador 45 & $0,49 \pm 0,10$ & $0,10 \pm 0,02$ \\
\hline
\end{tabular}

Os resultados de redução da captação tumoral de derivados da bombesina radiomarcados após a pré-administração de derivados da bombesina não radiomarcados já foram reportados em vários estudos (Hoffman et al., 2003; Rogers et al., 2003; Lantry et al., 2006; Biddlecombe et al., 2007; Faintuch et al., 2008). A intensidade da redução observada é variável, bem como a redução da captação abdominal, especialmente da captação pancreática. Essa variação observada reforça que o grupamento espaçador influi diretamente sobre a ligação preferencial do derivado da bombesina ao receptor para GRP. Provavelmente, também são essas diferenças que determinam o metabolismo pelas enzimas do soro in vivo, a cinética sanguínea, a excreção, a distribuição e tipo de interação radiofármaco-receptor (iônica, covalente ou forças de Van der Walls) de cada um dos peptídeos. Todas essas características em conjunto determinam se um derivado da bombesina tem ou não potencial para aplicação em estudos clínicos e ainda para qual aplicação o derivado é mais adequado, se para diagnóstico ou terapia.

\subsubsection{Estudos de imagem em camundongos Nude com tumor PC-3}

A fim de avaliar se os derivados da bombesina radiomarcados podem ser utilizados como ferramenta diagnóstica do câncer de próstata, realizou-se estudos de imagem utilizando a gama câmara. As imagens foram adquiridas dos camundongos em decúbito lateral, com o tumor localizado à esquerda, e bloqueando-se os rins e a bexiga 
com uma blindagem de chumbo, de modo a evitar que a alta captação nesses dois órgãos impedisse a visualização do tumor. Os resultados são mostrados nas FIG. 56, 57, 58, 59 e 60. As setas e os círculos vermelhos nas figuras indicam a localização do tumor e áreas com maior concentração de atividade são mostradas em negro, seguidas em ordem decrescente de atividade pelas cores laranja, amarelo, verde, azul, vermelho e cinza.

As imagens mostram que, apesar da baixa captação tumoral dos derivados evidenciada nos estudos de biodistribuição invasivos, a localização do tumor por estudos de imagem é possível, especialmente 30 minutos após a administração. Esses estudos demonstram a viabilidade do emprego de todos os derivados estudados em medicina nuclear, embora a captação tumoral, 1 hora após a administração, é retratada com melhor resolução utilizando-se os derivados $\mathrm{BEFG}_{3^{-}}{ }^{177} \mathrm{Lu}$ (FIG. 58), $\mathrm{BEFG}_{4^{-}}{ }^{177} \mathrm{Lu}$ (FIG. 59) e BEFG $_{5-}{ }^{177}$ Lu (FIG. 60).

Apesar de o lutécio-177 não ser um radioisótopo adequado para aplicações diagnósticas, uma vez que apresenta emissão $\beta^{-}$abundante, a emissão concomitante de radiação $\gamma$ de $208 \mathrm{keV}$ de energia (13\%) confere ao ${ }^{177} \mathrm{Lu}$ possibilidade de obtenção de imagem cintilográfica (Mikolajczak et al., 2003). No entanto, para radiofármacos de ${ }^{177} \mathrm{Lu}$, essa possibilidade é apenas adicional à aplicação terapêutica. A emissão de radiação gama abundante é a característica desejável de radioisótopos para aquisição de imagens cintilográficas e aplicação em tomografia por emissão de fóton único (SPECT) (Jurisson et al., 2008).

Em procedimentos diagnósticos, faz-se necessário a marcação dos derivados da bombesina com radioisótopos emissores de radiação gama abundante e de baixa energia, para diagnóstico por SPECT, ou emissores de pósitron, para diagnóstico por PET. Dentre os radioisótopos possíveis estão o ${ }^{111} \mathrm{In}$, para uso em SPECT, e o ${ }^{68} \mathrm{Ga}$, para uso em PET. Esses dois radioisótopos apresentam química de complexação semelhante ao ${ }^{177} \mathrm{Lu}$ e são facilmente complexados ao quelante DOTA. A radiomarcação com esses isótopos, dentre outros, amplia o espectro dos derivados da bombesina estudados e ainda oferece a vantagem da aquisição de imagens de melhor qualidade e de menores efeitos adversos aos pacientes decorrentes da exposição à radiação ionizante. 


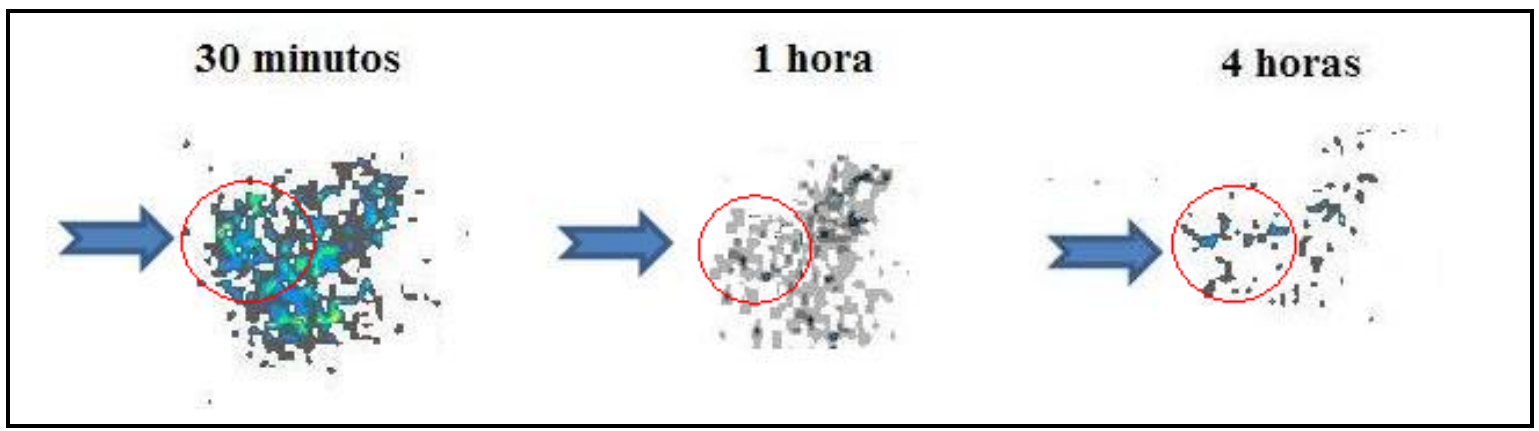

FIGURA 56 - Imagem cintilográfica de tumor de células PC-3 diferentes tempos após a administração de $37 \mathrm{MBq}(1 \mathrm{mCi})$ do derivado da bombesina $\mathrm{BEFG}_{1^{-}}{ }^{177} \mathrm{Lu}$ em camundongos Nude.

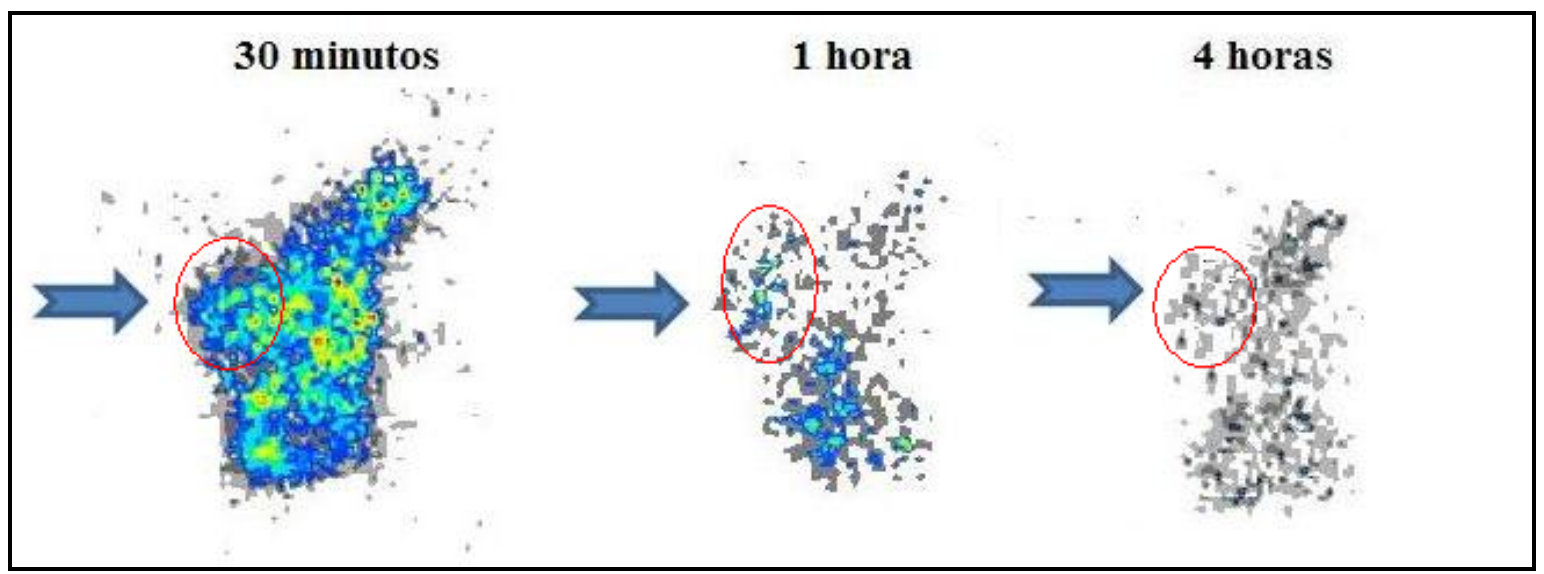

FIGURA 57 - Imagem cintilográfica de tumor de células PC-3 diferentes tempos após a administração de $37 \mathrm{MBq}(1 \mathrm{mCi})$ do derivado da bombesina $\mathrm{BEFG}_{2^{-}}{ }^{177} \mathrm{Lu}$ em camundongos Nude.

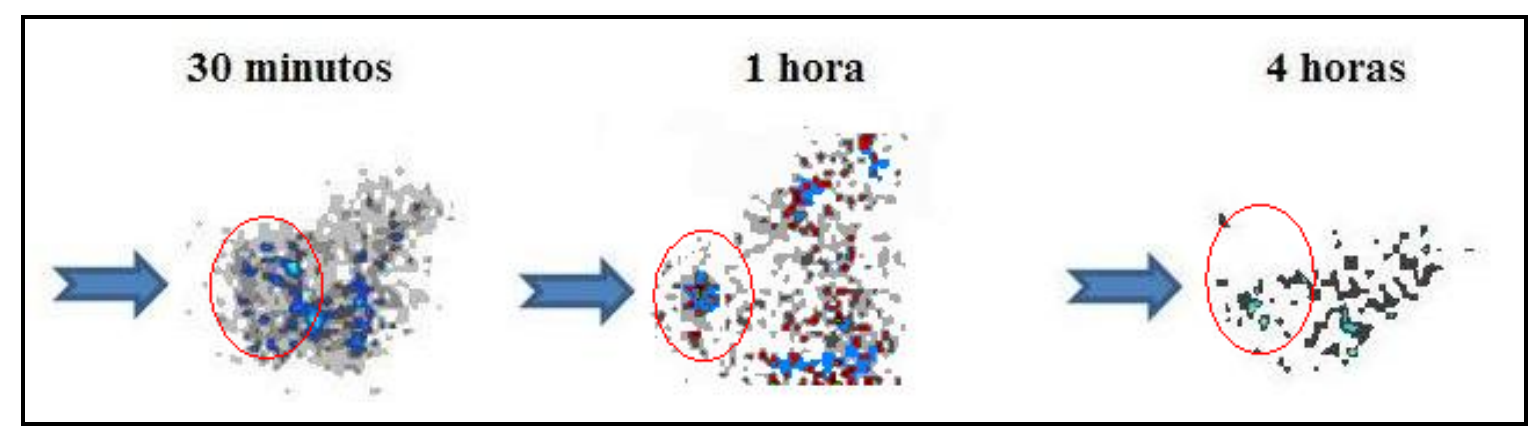

FIGURA 58 - Imagem cintilográfica de tumor de células PC-3 diferentes tempos após a administração de $37 \mathrm{MBq}(1 \mathrm{mCi})$ do derivado da bombesina $\mathrm{BEFG}_{3}{ }^{177} \mathrm{Lu}$ em camundongos Nude. 


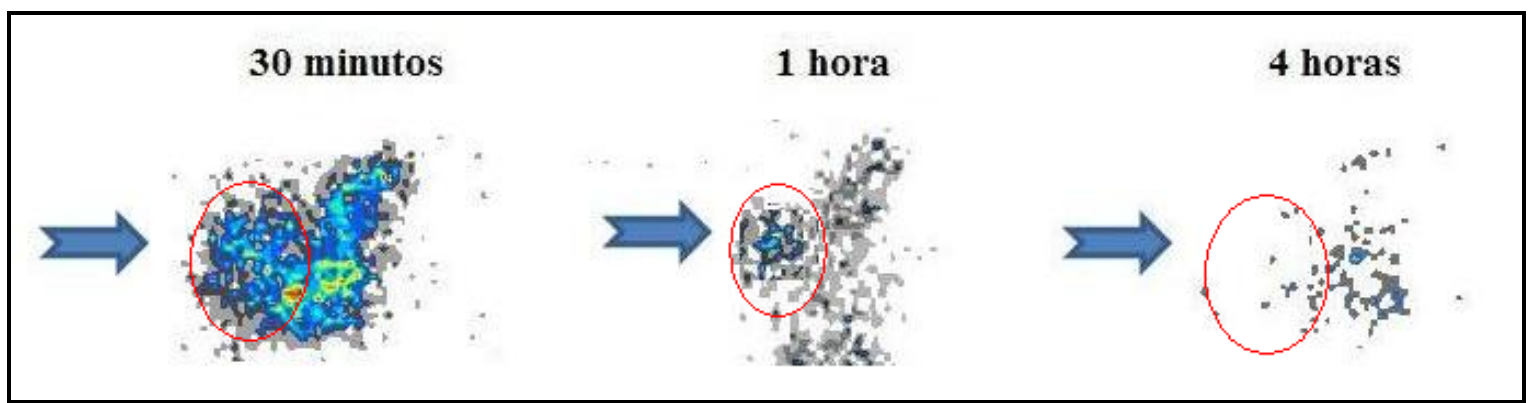

FIGURA 59 - Imagem cintilográfica de tumor de células PC-3 diferentes tempos após a administração de $37 \mathrm{MBq}(1 \mathrm{mCi})$ do derivado da bombesina $\mathrm{BEFG}_{4^{-}}{ }^{177} \mathrm{Lu}$ em camundongos Nude.

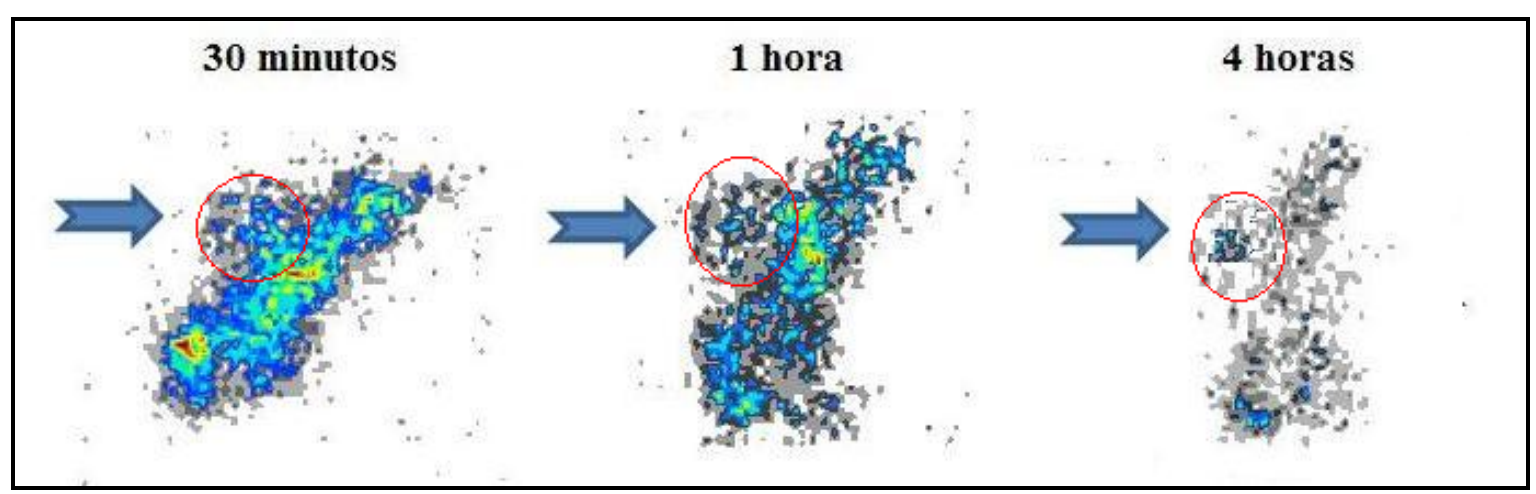

FIGURA 60 - Imagem cintilográfica de tumor de células PC-3 diferentes tempos após a administração de $37 \mathrm{MBq}(1 \mathrm{mCi})$ do derivado da bombesina $\mathrm{BEFG}_{5^{-}}{ }^{177} \mathrm{Lu}$ em camundongos Nude.

Como constatado no perfil de distribuição biológica em camundongos Balb-c sadios e em Nude implantados com tumor PC-3, a vantagem desses diferentes radiofármacos derivados da bombesina é a capacidade da fração não ligada ao tumor ser rapidamente depurada do organismo pelo sistema renal, reduzindo-se a preocupação em termos dosimétricos.

As imagens cintilográficas obtidas em camundongos Nude refletem de modo transparente o declínio da radioatividade retida no organismo no transcurso do tempo e a permanência, ainda que baixa, de atividade na área tumoral. O intervalo de contagem na gama-câmara poderia ser aumentado a fim de melhorar a resolução das imagens, no entanto, fugiria do propósito de visualizar o comportamento dos radiofármacos in vivo frente às células tumorais. 


\subsection{Estudos in vitro}

\subsubsection{Efeito dos derivados da bombesina sobre a viabilidade metabólica das células} PC-3

O efeito dos derivados da bombesina não radiomarcados sobre a proliferação das células PC-3 in vitro foi determinado através do ensaio com o MTS e o resultado pode ser visualizado na FIG. 61. Não houve alteração significativa na proliferação das células PC-3 $(\mathrm{p}=0,52)$ na presença dos derivados da bombesina em todas as concentrações estudadas $\left(1-10^{4} \mathrm{nM}\right)$. Esse resultado, aliado aos resultados de captação tumoral in vivo, os quais mostraram captação tumoral, mas redução significativa da radioatividade do tumor nas primeiras 4 horas, sugere que os derivados $\mathrm{BEFG}_{1}, \mathrm{BEFG}_{2}, \mathrm{BEFG}_{3}, \mathrm{BEFG}_{4} \mathrm{e}$ $\mathrm{BEFG}_{5}$ não são agonistas dos receptores para GRP.

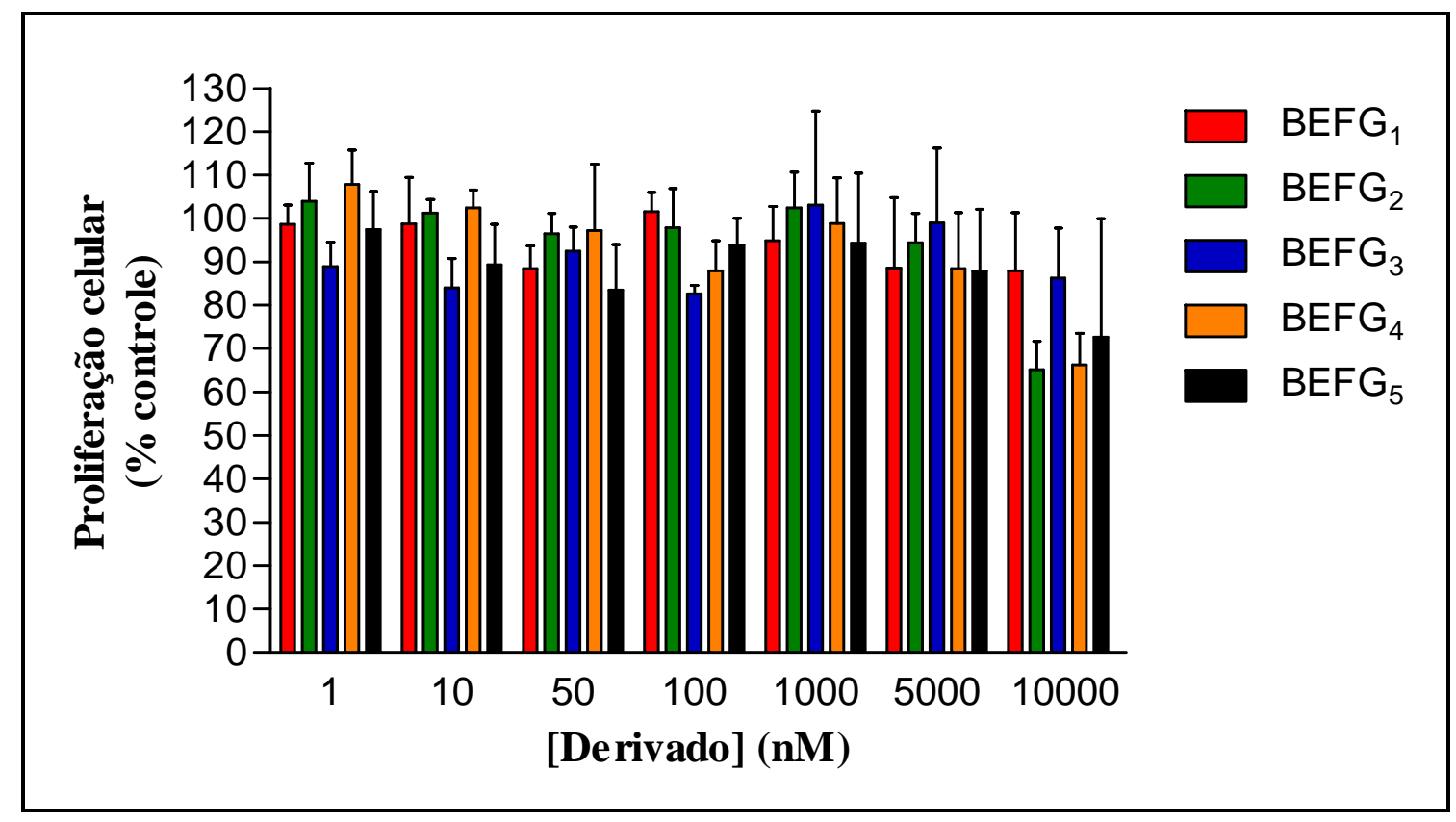

FIGURA 61 - Efeito de diferentes concentrações dos derivados da bombesina sobre a proliferação das células PC-3 in vitro após 72 horas de incubação.

A ligação dos agonistas da bombesina aos receptores para GRP desencadeia uma série de respostas intracelulares que leva à divisão celular por mitose (Levine et al., 2003; Zhu et al., 2007). Dentre as respostas intracelulares ativadas estão o aumento da concentração intracelular de inositol fosfato, diacilglicerol e cálcio. A maioria dos derivados da bombesina radiomarcados propostos na literatura são agonistas da bombesina. Os agonistas possuem a capacidade de induzir a internalização mediada por receptor, 
principalmente por endocitose. O acúmulo do radiofármaco no interior da célula pode ser importante para garantir que a maior dose de radiação esteja em contato com as célulasalvo e suas organelas, obtendo-se assim uma maior eficácia terapêutica (Abd-Elgaliel et al., 2008).

Os antagonistas da bombesina, na presença de um agonista ou isoladamente, impedem a resposta mitótica e levam à morte celular por apoptose (Stangelberger et al., 2005; Patel et al., 2006; Zhu et al., 2007; Cescato et al., 2008). Zhu e colaboradores (2007) observaram esses efeitos citotóxicos de derivados antagonistas da bombesina na concentração de $50 \mathrm{nM}$, significativamente menor do que a maior concentração dos derivados da bombesina testados $\left(10^{4} \mathrm{nM}\right)$. Como esse efeito não foi observado, acreditase que esses derivados da bombesina estudados são agonistas fracos ou antagonistas dos receptores para GRP. Neste último caso, a ação antagonista só seria observada na presença de um agonista. No entanto, outros estudos in vitro, tais como estudos de ligação, internalização e externalização devem ser realizados a fim de confirmar se os derivados em estudo são agonistas ou antagonistas desses receptores.

Até o presente, tem-se estabelecido que a internalização, bem como alta captação tumoral in vivo, são propriedades desejáveis a análogos da bombesina para aplicação no diagnóstico e terapia radioisotópica. Do ponto de vista molecular e farmacológico, essas propriedades pertencem predominantemente a agonistas dos GRPr. Entretanto, demonstrou-se recentemente que antagonistas da bombesina, os quais são pouco internalizados, promoveram resultados iguais ou até melhores nos estudos préclínicos dos que os observados com agonistas (Stangelberger et al., 2005; Cescato et al., 2008). Esses resultados provavelmente se devem ao fato de que não é necessário que o radiofármaco esteja no interior das células para que a radiação exerça efeito citotóxico sobre as células tumorais. Além disso, radiofármacos massivamente internalizados pelas células tumorais também são internalizados pelos tecidos sadios que expressam receptores para essas moléculas, dificultando sua eliminação e aumentando a probabilidade da ocorrência de efeitos adversos. 


\section{CONCLUSÕES}

\subsection{Radiomarcação dos derivados da bombesina}

Todos os derivados da bombesina estudados neste trabalho podem ser facilmente radiomarcados com lutécio-177 com alta pureza radioquímica ( $>95 \%)$ e atividade específica adequada, na condição em que se mistura $20 \mu \mathrm{g}$ do derivado a 92,5 $\operatorname{MBq}(2,5 \mathrm{mCi}) \mathrm{de}{ }^{177} \mathrm{LuCl}_{3}$, em um volume de $200 \mu \mathrm{L}, \mathrm{pH} 4,5$, a $90^{\circ} \mathrm{C}$ por 30 minutos e agitação de $350 \mathrm{rpm}$. Esse procedimento de radiomarcação apresenta reprodutibilidade para todos os derivados, não sendo necessário procedimento de purificação para sua utilização nos demais ensaios. As reações de radiomarcação dos derivados também dão origem a um produto primário de degradação, provavelmente decorrente da alta temperatura e $\mathrm{pH}$ ácido em que ocorrem e da ausência de agentes estabilizantes. Esse produto provavelmente corresponde aos derivados com o aminoácido metionina oxidado (Met-O).

\subsection{Estabilidade dos derivados da bombesina radiomarcados}

Todos os derivados apresentam alta estabilidade frente à descomplexação do lutécio-177, quando as misturas de radiomarcação são armazenadas em geladeira à $2-8^{\circ} \mathrm{C}$. A pureza radioquímica permanece maior do que 95\% até após 96 horas (quatro dias) de armazenamento nessa temperatura. Aparentemente, não existe relação entre a estrutura dos derivados da bombesina estudados e sua estabilidade à $2-8^{\circ} \mathrm{C}$.

Após incubação em soro humano à $37^{\circ} \mathrm{C}$, todos os derivados da bombesina estudados apresentam baixa estabilidade e são metabolizados pelas enzimas do soro de forma tempo-dependente. Esse metabolismo provavelmente envolve quebra na cadeia de aminoácidos ou no grupo quelante e não apenas descomplexação do radiolantanídeo. Apesar de após 24 horas apenas uma pequena porcentagem deles ainda permanecer inalterada, a estabilidade desses peptídeos é maior do que a da bombesina nativa. A adição de aminoácidos glicina ao espaçador dos derivados aumentou sua estabilidade em soro humano in vitro até após 4 horas de incubação, sendo o $\mathrm{BEFG}_{1^{-}}{ }^{177} \mathrm{Lu}$ o derivado menos estável e o $\mathrm{BEFG}_{5^{-}}{ }^{177} \mathrm{Lu}$ o mais estável nas condições estudadas. 


\subsection{Lipossolubilidade dos derivados da bombesina radiomarcados}

Os derivados da bombesina com espaçadores aminoacídicos, compostos pelo aminoácido fenilalanina e uma cadeia de aminoácidos glicina de tamanho variável, apresentam baixa lipossolubilidade. Além disso, o aumento no número de aminoácidos glicina do espaçador diminui, ainda que discretamente, a lipossolubilidade dos derivados.

\subsection{Estudos in vivo em camundongos Balb-c}

Os derivados da bombesina estudados neste trabalho apresentam rápido clareamento sanguíneo e rápida excreção, a qual é realizada primariamente por via renal e tardiamente por via hepatointestinal. A relação entre a adição de aminoácidos glicina ao espaçador dos derivados e a discreta redução da lipossolubilidade não foi observada nos valores de captação hepática e renal in vivo. A redução na lipossolubilidade é provavelmente muito discreta para provocar uma mudança na biotransformação e via de excreção dos derivados da bombesina in vivo. Ao contrário da maioria dos derivados da bombesina reportados até o presente, $\mathrm{BEFG}_{1^{-}}{ }^{177} \mathrm{Lu}, \mathrm{BEFG}_{2^{-}}{ }^{177} \mathrm{Lu}, \mathrm{BEFG}_{3^{-}}{ }^{177} \mathrm{Lu}, \mathrm{BEFG}_{4^{-}}$

${ }^{177} \mathrm{Lu}$ e $\mathrm{BEFG}_{5^{-}}{ }^{177} \mathrm{Lu}$ apresentam baixo acúmulo abdominal, principalmente no pâncreas e no intestino.

Todos os derivados se mostraram estáveis frente à descomplexação do lutécio177 in vivo nas primeiras horas após a administração, mas a liberação do radiolantanídeo após o metabolismo tardio é responsável pela retenção de uma pequena fração da radioatividade injetada no organismo, provavelmente nos ossos. Apesar da retenção dessa pequena fração, todo o restante da radioatividade injetada é eliminado do organismo nas primeiras quatro horas após a administração, com exceção do derivado mais hidrossolúvel - BEFG $_{5^{-}}{ }^{177} \mathrm{Lu}$ - para o qual a concentração no organismo atinge o valor mínimo duas horas e trinta minutos após a administração.

O modelo farmacocinético desses derivados mostra ser do tipo multicompartimental, no qual foram identificados cinco compartimentos. Os principais órgãos-alvo são os rins, o intestino, o fígado, os músculos e o osso. Apesar da discreta diferença entre a farmacocinética dos derivados estudados e da dificuldade em estabelecer uma relação entre os resultados dos estudos cinéticos e sua estrutura, o derivado $\mathrm{BEFG}_{1}$ ${ }^{177} \mathrm{Lu}$ apresentou um maior volume de distribuição e uma menor constante de transferência do espaço vascular para o sistema excretor, indicando que a maior lipofilicidade, ainda que discreta, dificulta a excreção renal. 
As imagens cintilográficas planares mostraram que radiofármacos de lutécio177, além de serem aplicados em terapia radioisotópica, podem ser utilizados como ferramentas diagnósticas. Essas propriedades são desejáveis a radiofármacos para diagnóstico e terapia radioisotópica em medicina nuclear.

\subsection{Estudos in vivo em camundongos Nude implantados com tumor de células PC-3}

O modelo animal de tumor de próstata humano desenvolvido em camundongos Nude foi validado pela análise histológica de alguns tumores. Os tumores são formados por células pouco diferenciadas, com crescimento desorganizado, e apresentavam alta celularidade, presença de vasos sanguíneos e ausência de infiltrado inflamatório. Essas são características de transformações malignas.

Todos os derivados são significativamente captados pelo tumor de células PC-3 nos estudos de biodistribuição, mas os dois peptídeos com maior espaçador $-\mathrm{BEFG}_{4^{-}}{ }^{177} \mathrm{Lu}$ e $\mathrm{BEFG}_{5^{-}}{ }^{177} \mathrm{Lu}$ - apresentam maior captação tumoral 1 hora após a administração endovenosa, mas não a partir de 4 horas, quando a captação de todos os derivados se iguala, considerando-se a captação tumoral em relação à atividade injetada. Quando se considera a captação tumoral em relação à radioatividade presente no organismo, a maior captação tumoral desses derivados na primeira hora se confirma, mas o derivado com menor espaçador $-\mathrm{BEFG}_{1-}{ }^{177} \mathrm{Lu}$ - apresenta maior captação tumoral 4 e 24 horas após a administração.

Da mesma forma que nos camundongos Balb-c, os derivados da bombesina são rapidamente excretados principalmente por via renal e apresentam baixo acúmulo abdominal, especialmente no pâncreas. Esse baixo acúmulo abdominal é a principal vantagem desses novos derivados em relação aos já descritos pela literatura. Apesar da ligação dos derivados da bombesina ao tumor de células PC-3 também ser menor em relação a alguns derivados reportados, essa ligação mostrou ser específica e suficiente para a detecção do tumor por imagens cintilográficas, principalmente 30 minutos após a administração. A aquisição das imagens foi possível com todos os derivados estudados, mas a captação tumoral 1 hora após a administração é mais visível com os derivados $\mathrm{BEFG}_{3^{-}}{ }^{177} \mathrm{Lu}, \mathrm{BEFG}_{4^{-}}{ }^{177} \mathrm{Lu}$ e $\mathrm{BEFG}_{5^{-}}{ }^{177} \mathrm{Lu}$. Além disso, apesar da adição de um aminoácido glicina ao espaçador não alterar significativamente a captação tumoral, ela pode influenciar diretamente na especificidade dessa ligação, favorecendo a interação radiofármaco-receptor. 


\subsection{Atividade agonista ou antagonista dos derivados da bombesina}

Os derivados da bombesina estudados não apresentaram efeito proliferativo ou citotóxico sobre as células PC-3 in vitro, característica de agonistas fracos ou antagonistas dos receptores para GRP.

\subsection{Potencial dos derivados da bombesina para aplicação em diagnóstico e terapia de tumor de próstata}

Todos os derivados estudados neste trabalho apresentaram resultados promissores para aplicação in vivo. A significativa captação tumoral, o baixo acúmulo nos tecidos sadios, a baixa retenção no organismo, a excreção rápida e o rápido clareamento sanguíneo fazem desses novos derivados da bombesina radiofármacos em potencial para diagnóstico e terapia de tumor de próstata. A baixa captação dos derivados na próstata normal permite a aplicação dos derivados da bombesina não apenas no diagnóstico e terapia de tumores de próstata metastáticos, mas também no diagnóstico e terapia de tumores localizados e ainda no diagnóstico diferencial o adenocarcinoma prostático e as demais patologias que acometem a próstata, tais como hiperplasia e tumores benignos.

A maior captação tumoral dos derivados $\mathrm{BEFG}_{4^{-}}{ }^{177} \mathrm{Lu}$ e $\mathrm{BEFG}_{5^{-}}{ }^{177} \mathrm{Lu}$ na primeira hora após a administração endovenosa indica que esses derivados são os mais adequados para o diagnóstico por imagem de tumor de próstata. Já para aplicação em terapia radioisotópica, o derivado $\mathrm{BEFG}_{1^{-}}{ }^{177} \mathrm{Lu}$ é o mais adequado, devido à maior atividade no tumor em relação ao total no organismo 4 e 24 horas após a administração. Entretanto, estudos dosimétricos deverão ser realizados para determinar qual dos derivados apresenta a melhor relação risco-benefício para o paciente, considerando-se a aplicação em terapia. 


\section{PRÓXIMAS ETAPAS}

As próximas etapas deste trabalho são:

$\checkmark$ Alterar parâmetros das reações de marcação e estudar a adição de agentes estabilizantes às mesmas, de modo a evitar a oxidação da metionina;

$\checkmark$ avaliar o efeito da oxidação da metionina sobre a ligação dos derivados da bombesina a seus receptores in vivo;

$\checkmark$ estudar os metabólitos dos derivados da bombesina após incubação em soro humano in vitro;

$\checkmark$ analisar a ligação, a internalização e a externalização dos derivados da bombesina radiomarcados nas células $\mathrm{PC}-3$ in vitro;

$\checkmark$ desenvolver um protocolo terapêutico para analisar a eficácia terapêutica do $\mathrm{BEFG}_{1}$ ${ }^{177}$ Lu no modelo animal de câncer de próstata humano;

$\checkmark$ radiomarcar os derivados da bombesina $\mathrm{BEFG}_{4}$ e $\mathrm{BEFG}_{5}$ com radioisótopos adequados para aplicação exclusivamente em procedimentos diagnósticos como PET e SPECT e avaliar sua ligação a células de tumor de próstata in vivo, bem como a células de outros tipos de tumores, como mama, pâncreas;

$\checkmark$ realizar estudos de tolerância toxicológica dos derivados da bombesina não radiomarcados;

$\checkmark$ elaborar um piloto de radiomarcação com alta atividade e de acordo com as boas práticas de fabricação de injetáveis para futura aplicação em estudos clínicos;

$\checkmark$ de acordo com os resultados obtidos nos estudos acima, viabilizar a realização de estudos clínicos com os derivados estudados ou promover modificações em sua estrutura para melhorar seu potencial como radiofármaco. 


\section{REFERÊNCIAS BIBLIOGRÁFICAS}

[1] ABD-ELGALIEL, W.R.; GALLAZZI, F.; GARRISON, J.C.; ROLD, T.L.; SIECKMAN, G.L.; FIGUEROA, S.D.; HOFFMAN, T.J.; LEVER, S.Z. Design, synthesis and biological evaluation of an antagonist-bombesin analogue as targeting vector. Bioconjugate Chem, v. 19, p. 2040-2048, 2008.

[2] AMINOÁCIDOS. Disponível em

$<$ http://it.wikipedia.org/w/index.php?title=Image\%3AAmminoacido_glicina_form ula.svg here>. Acesso em 21 mar, 2009.

[3] ANASTASI, A.; ERSPAMER, V.; BUCCI, M. Isolation and structure of bombesin and alytesin, two analogous active peptides from the skin of the european amphibians Bombina and Alytes. Experientia, v. 27, p. 166-167, 1970.

[4] BIDDLECOMBE, G. B.; ROGERS, B. E.; DE VISSER, M.; PARRY, J. J.; DE JONG, M.; ERION, J . L.; LEWIS, J. S. Molecular imaging of gastrin-releasing peptide receptor-positive tumors in mice using ${ }^{64} \mathrm{Cu}$ and ${ }^{86} \mathrm{Y}$-DOTA-(Pro $\left.{ }^{1}, \mathrm{Try}^{4}\right)$ Bombesin(1-14). Bioconjugate Chem, v. 18, p. 724-730, 2007.

[5] BRASILEIRO FILHO, G.; GUIMARÃES, R.C.; BOGLIOLO, L. Distúrbios do crescimento e da diferenciação celular. In: BRASILEIRO FILHO, G. Bogliolo: Patologia Geral. Rio de Janeiro: Guanabara Koogan, 1998. Cap. 8.

[6] BREEMAN, W.A.; DE JONG, M.; ERION, J.L; BUGAJ, J. E.; SRINIVASAN, A.; BERNARD, B. F.; KWEKKEBOOM, D. J.; VISSER, T.J.; KREENING, E.P. Preclinical comparison of ${ }^{111}$ In-labeled DTPA- or DOTA-bombesin analogs for receptor-targeted scintigraphy and radionuclide therapy. $\boldsymbol{J}$ Nucl Med, v. 43, n. 12, p. 1650-1656, 2002.

[7] BREEMAN, W.A.; DE JONG, M.; VISSER, T.J.; ERION, J.L; KREENING, E.P. Optimising conditions for radiollabeling of DOTA-peptides with ${ }^{90} \mathrm{Y},{ }^{111} \mathrm{In}$, and ${ }^{177}$ Lu at high specific activities. Eur J Nucl Med Mol Imaging, v. 30, n. 6, p. 917 920, 2003.

[8] BRASILEIRO FILHO, G. Bogliolo Patologia. Rio de Janeiro: Guanabara Koogan, 2000.

[9] CAMPBELL, M. K. Bioquímica. Porto Alegre: Artmed Editora, 2001. cap. 3, aminoácidos e proteínas. p. 96-117. 
[10] CESCATO, R.; MAINA, T.; NOCK, B.; NIKOLOPOULOU, A.; CHARALAMBIDIS, D.; PICCAND, V.; REUBI, J. C. Bombesin receptor antagonists may be preferable to agonists for tumor targeting. J Nucl Med, v. 49, p. 318-326, 2008.

[11] CHEN, J.; LINDER, K. E.; CAGNOLINI, A.; METCALFE, E.; RAJU, N.; TWEEDLE, M. F.; SWENSON, R. E. Synthesis, stabilization and formulation of $\left[{ }^{177} \mathrm{Lu}\right] \mathrm{Lu}-\mathrm{AMBA}$, a systemic radiotherapeutic agent for gastrin releasing peptide receptor positive tumors. Appl Rad Isot, v. 66, p. 497-505, 2008.

[12] DABUR RESEARCH FOUNDATION. A. C. Burman, S. Prasad, R. Mukherjee, M. Jaggi, A. T. Singh, A. Mathur. Bombesin analogs for treatment of cancer. US 6989371, 31 jul 2000, 24 jan 2006.

[13] DE ARAÚJO, E. B.; CALDEIRA FILHO, J. S.; NAGAMATI, L. T.; MURAMOTO, E.; COLTURATO, M. T.; COUTO, R. M.; PUJATTI, P. B.; MENGATTI, J.; SILVA, C. P. G. A comparative study of ${ }^{131}$ I and ${ }^{177}$ Lu labeled somatostatin analogues for therapy of neuroendocrine tumors. Appl Rad Isot, n. 67, p. 227-233, 2009.

[14] DURKAN, K.; LAMBRECHT, F. Y.; UNAK, P. Radiolabeling of bombesin-like peptide with ${ }^{99 \mathrm{~m}} \mathrm{Tc}:{ }^{99 \mathrm{~m}} \mathrm{Tc}$-litorin and biodistribution in rats. Bioconjugate Chem, v. 18, p. 1516-1520, 2007.

[15] ENGEL, J.B.; SCHALLY, A.V.; DIETL, J.; RIEGER, L.; HÖNIG, A. Targeted therapy of breast and gynecological cancer with cytotoxic analogues of peptide hormones. Mol Pharm, v. 4, n. 5, p. 652-658, 2007.

[16] EPSTEIN, J.I. O Trato Urinário Inferior e o Sistema Genital Masculino. In: ROBBINS, S.L.; COTRAN, R.S. Patologia - Bases Patológicas das Doenças. Rio de Janeiro: Elsevier, 2005. p. 1068-1104.

[17] ESTRUTURA DO PEPTÍDEO BOMBESINA. Disponível em $<$ http://upload.wikimedia.org/wikipedia/commons/thumb/c/c4/Bombesin.png/350p x-Bombesin.png>. Acesso em 06 mar, 2009.

[18] FAINTUCH, B. L.; TEODORO, R.; DUATTI, A.; MURAMOTO, E.; FAINTUCH, S.; SMITH, S. Radiolabeled bombesin analogs for prostate cancer diagnosis: preclinical studies. Nucl Med Biol, v. 35, p. 401-411, 2008

[19] GARAYOA, E. G.; SCHWEINSBERG, C.; MAES, V.; RÜEGG, D.; BLANC, A.; BLÄUENSTEIN, P.; TOURWÉ, D. A.; BECK-SICKINGER, A. G.; SCHUBIGER, P. A. New [ ${ }^{99 \mathrm{~m}}$ Tc]bombesin analogues with improved biodistribution for targeting gastrin releasing-peptide receptor positive tumors. Q J Nucl Med Mol Imaging, v. 51, p. 42-50, 2007. 
[20] GARRISON, J.C.; ROLD, T.L.; SIECKMAN, G.L.; NAZ, F.; SUBLETT, S.V.; FIGUEROA, S.D.; VOLKERT, W.A.; HOFFMAN, T.J. Evaluation of the pharmacokinetic effects of various linking group using the ${ }^{111}$ In-DOTA-X$\mathrm{BBN}(7-14) \mathrm{NH}_{2}$ structural paradigm in a prostate cancer model. Bioconjugate Chem, v. 19, p. 1803-12, 2008.

[21] GOTTHARDT, M.; EERD-VISMALE, J. van; OYEN, W. J. G.; DE JONG, M.; ZHANG, H.; ROLLEMAN, E.; MAECKE, H. R.; BÉHÉ, M.; BOERMAN, O. Indication for different mechanisms of kidney uptake of radiolabeled peptides. J Nucl Med, v. 48, p. 596-601, 2007.

[22] HALEY, T. J.; KOMESU, N.; EFRUS, M.; KOSTE, L.; UPHAN, H. C. Pharmacology and toxicology of lutetium chloride. J Pharm Sci, v. 53, p. 11861188, 1964.

[23] HOFFMAN, T.J.; GALI, H.; SMITH, C.J.; SIECKMAN, G.L.; HAYES, D.L.; OWEN, N.K.; VOLKERT, W.A. Novel series of ${ }^{111}$ In-labeled bombesin analogs as potential radiopharmaceuticals for specific targeting of gastrin-releasing peptide receptors expressed on human prostate cancer cells. J Nucl Med, v. 44, p. 823-831, 2003.

[24] HU, F.; CUTLER, C. S.; HOFFMAN, T.; SIECKMAN, G.; VOLKERT, W. A.; JURISSON, S. S. Pm-149 DOTA bombesin analogs for potential radiotherapy in vivo comparison with Sm-153 and Lu-177 labeled DO3A-amide- $\beta$ Ala-BBN(714) $\mathrm{NH}_{2}$. Nucl Med Biol, v. 29, n. 4, p. 423-430, 2002.

[25] IMPÉRIO, M.D. Câncer de Próstata. IN: GUIMARÃES, J.R.Q. Manual de Oncologia. São Paulo: BBS Editora, 2004. p. 411-417.

[26] INSTITUTO NACIONAL DO CÂNCER. Estimativa da incidência de câncer no Brasil 2008. Disponível em: $<$ http://www.inca.gov.br/estimativa/2008>. Acesso em: 03 mar. 2009.

[27] JIMÉNEZ, Y. V. Dosimetria interna aplicada a farmacos marcados con ${ }^{177} \mathrm{Lu}$. 2007. Dissertação (Mestrado). Instituto Balseiro, Cuyo.

[28] JOHNSON, C. V.; SHELTON, T.; SMITH, C. J.; MA, L.; PERRY, M. C.; VOLKERT, W. A.; HOFFMAN, T. J. Evaluation of combined ${ }^{177}$ Lu-DOTA-8AOC-BBN(7-14) $\mathrm{NH}_{2}$ GRP receptor-targeted radiotherapy and chemotherapy in PC-3 human prostate tumor cell xenografted SCID mice. Cancer Biother Radiopharm, v. 21, n. 2, p. 155-65, 2006.

[29] JUNQUEIRA, L.C.; CARNEIRO, J. Histologia Básica. Rio de Janeiro: Guanabara Koogan, 1999. 
[30] JURISSON, S.; CUTLER, C.; SMITH, S.V. Radiometal complexes: characterization and relevant in vitro studies. Q J Nucl Med Mol Imaging, v. 52, p. 222-234, 2008

[31] KASSIS, A.I.; ADELSTEIN, S.J. Considerations in the selection of radionuclides for cancer therapy. In: WELCH, M.J.; REDVANLY, C.S. Handbook of Radiopharmaceuticals: radiochemistry and applications. Chichester: Wiley, 2003. Cap. 27.

[32] KNIGHT, L.C. Radiolabeled peptides for tumor imaging. In: WELCH, M.J.; REDVANLY, C.S. Handbook of Radiopharmaceuticals: radiochemistry and applications. Chichester: Wiley, 2003. Cap. 23.

[33] KWEKKEBOOM, D.J.; BAKKER, W.H.; KAM, B.L.; TEUNISSEN, J.J.M.; KOOIJ, P.P.M.; HERDER, W.W.; FEELDERS, R.A.; EIJCK, C.H.J.; DE JONG, M.; SRINIVASAN, A.; ERION, J.L.; KRENNING, E.P. Treatment of patients with gastro-entero-pancreatic (GEP) tumours with the novel radiolabelled somatostatin analogue $\left[{ }^{177}\right.$ Lu DOTA ${ }^{0}$, Try $\left.^{3}\right]$ octreotate. Eur J Nucl Med Mol Imaging, vol. 30, p. 417-422, 2003.

[34] LA BELLA, R.; GARAYOA, E. G.; LANGER, M.; BLAUENSTEIN, P.; BECKSICKINGER, A. G.; SCHUBIGER, P. A. In vitro and in vivo evaluation of a ${ }^{99 \mathrm{~m}} \mathrm{Tc}(\mathrm{I})$-labeled bombesin analogue for imaging of gastrin releasing peptide receptor-positive tumors. Nucl Med Biol, v. 29, p. 553-560, 2002.

[35] LANE, S. R.; VEERENDRA, B.; ROLD, T. L.; SIECKMAN, G. L.; HOFFMAN, T. J.; JURISSON, S. S.; SMITH, C. J. ${ }^{99 \mathrm{~m}} \mathrm{Tc}(\mathrm{CO})_{3}$-DTMA bombesin conjugates having high affinity for the GRP receptor. Nucl Med Biol, v. 35, p. 263-272, 2008 .

[36] LANTRY, L. E.; CAPPELLETTI, E.; MADDALENA, M. E.; FOX, J. S.; FENG, W.; CHEN, J.; THOMAS, R.; EATON, S. M.; BOGDAN, N. J.; ARUNACHALAM, T.; REUBI, J.C.; RAJU, N.; METCALFE, E. C.; LATTUADA, L.; LINDER, K. E.; SWENSON, R. E.; TWEEDLE, M. F.; NUNN, A. D. ${ }^{177}$ Lu-AMBA: Synthesis and characterization of a selective ${ }^{177}$ Lu-labeled GRP-R agonist for systemic radiotherapy of prostate cancer. J Nucl Med, v. 47, n. 7, p. 1144-1152, 2006.

[37] LARA, P. F. Farmacocinética. IN: ZANINI, A. C.; OGA, S. Farmacologia aplicada. São Paulo: Atheneu, 1985. p. 35-45

[38] LEVINE, L.; LUCCI, J. A.; PAZDRAK, B.; CHENG, J. Z.; GUO, Y. S.; TOWNSEND, C. M.; HELLMICH, M. R. Bombesin stimulates nuclear factor $\kappa \mathrm{B}$ activation and expression of proangiogenic factors in prostate cancer cells. Cancer Res, v. 63, p. 3495-3502, 2003. 
[39] MAINA, T.; NOCK, B. A.; ZHANG, H.; NIKOLOPOULOU, A.; WASER, B.; REUBI, J. C.; MAECKE, H. R. Species differences of bombesin analog interactions with GRP-R define the choice of animal models in the development of GRP-R-targeting drugs. J Nucl Med, v. 46, p. 823-830, 2005.

[40] MAINA, T.; NOCK B.; MATHER, S. Targeting prostate cancer with radiolabelled bombesins. Cancer Imaging, v. 6, p. 153-157, 2006.

[41] MALICH, G.; MARKOVIC, B.; WINDER, C. The sensitivity and specificity of the MTS tetrazolium assay for detecting the in vitro cytotoxicity of 20 chemicals using human cell lines. Toxicology, v. 124, n. 3, p. 179-192, 1997.

[42] MARKWALDER, R.; REUBI, J. C. Gastrin-releasing receptors in human prostate: relation to neoplastic transformation. Cancer Res, v. 59, p. 1152-1159, 1999.

[43] MERRELL PHARMACEUTICALS INC. J. L. Krstenansky. Compounds and pharmaceutical uses of peptides of bombesin and GRP. US 5834433, $23 \mathrm{fev}$ 1996, 10 nov 1998.

[44] MIKOLAJCZAK, R.; PARUS, J.L.; PAWLAK D.; ZAKRZEWSKA, E.; MICHALAK, W.; SASINOWSKA, I. Reactor produced ${ }^{177}$ Lu of specific activity and purity suitable for medical applications. J Radioanal Nucl Chem, v. 257, $\mathrm{n}^{\circ}$. 1, p. 53-57, 2003.

[45] MOODY, T. W.; CRAWLEY, J. N.; JENSEN, R. T. Pharmacology and neurochemistry of bombesin-like peptides. Peptides, v. 3, n. 3, p. 559-563, 1982.

[46] MURPHY, R.; TONANTZITLA, I. Biexp. Puebla, México, 1991.

[47] OGA, S.; YASAKA, W. J. Biotransformação e excreção de drogas. IN: ZANINI, A. C.; OGA, S. Farmacologia aplicada. São Paulo: Atheneu, 1985. p. 49-58.

[48] OJOPI, E.P.B.; NETO, E.D. Genômica e Oncologia. IN: Genômica. São Paulo: Atheneu, 2004. Cap. 19.

[49] PARRY, J.J.; ANDREWS, R.; ROGERS, B. MicroPET imaging of breast cancer using radiolabeled bombesin analogues targeting the gastrin-releasing peptide receptor. Breast Cancer Res Treat, n. 101, p.175-183, 2007a.

[50] PARRY, J.J.; KELLY, T.S.; ANDREWS, R.; ROGERS, B.E. In vitro and in vivo evaluation of ${ }^{64} \mathrm{Cu}$-labeled DOTA-linker-bombesin(7-14) analogues containing different amino acid linker moieties. Bioconjugate Chem, v. 18, p. 1110-1117, $2007 b$. 
[51] PATEL, O.; SHULKES, A.; BALDWIN, G. S. Gastrin-releasing peptide and cancer. Biochim Biophys Acta, v. 1766, p. 23-41, 2006.

[52] PEPTIDE TECHNOLOGIES CORPORATION. M. Knight, K. Takahashi, B. Chandrasekhar. Bombesin receptor antagonists and uses thereof. US 5620955, 17 dez 1993, 15 abr 1997.

[53] PRASANPHANIC, A. F.; NANDA, P. K.; ROLD, T. L.; MA, L.; LEWIS, M. R.; GARRISON, J. C.; HOFFMAN, T. J.; SIECKMAN, G. L.; FIGUEROA, S. D.; SMITH, C. J. [ $\left.{ }^{64} \mathrm{Cu}-\mathrm{NOTA}-8-A o c-B B N(7-14) \mathrm{NH}_{2}\right]$ targeting vector for positronemission tomography imaging of gastrin-releasing peptide receptor-expressing tissues. PNAS, v. 104, n. 30, p. 12462-12467, 2007.

[54] REUBI, J.C. Peptide receptors as molecular targets for cancer diagnosis and therapy. Endocr Rev, v. 24, n. 4, p. 389-427, 2003.

[55] ROBBINS, S.L.; COTRAN, R.S. Neoplasia. In: ROBBINS, S.L.; COTRAN, R.S. Patologia - Bases Patológicas das Doenças. Rio de Janeiro: Elsevier, 2005. p. 282-356.

[56] ROGERS, B. E.; BIGOTT, H. M.; McCARTHY, D. W.; MANNA, D. D.; KIM, J.; SHARP, T. L.; WELCH, M. MicroPET imaging of a gastrin-releasing peptide receptor-positive tumor in a mouse modelo of human prostate câncer using a ${ }^{64} \mathrm{Cu}$-labeled bombesin analogue. Bioconjugate Chem, v. 14, p. 756-763, 2003.

[57] SANTOS-CUEVAS, C. L.; FERRO-FLORES, G.; DE MURPHY, C. A.; PICHARDO-ROMERO, P. A. Targeted imaging of gastrin-releasing peptide receptors with ${ }^{99 \mathrm{~m}}$ Tc-EDDA/HYNIC-[Lys $\left.{ }^{3}\right]$-bombesin: biokinetics and dosimetry in women. Nucl Med Commun, v. 29, p. 741-747, 2008.

[58] SAPIENZA, M. T.; BUCHPIEGUEL, C. A. Medicina Nuclear em oncologia. IN: GUIMARÃES, J.R.Q. Manual de Oncologia. São Paulo: BBS Editora, 2004. p. 675-683.

[59] SISTEMA REPRODUTOR MASCULINO. Disponível em $<$ http://www.revistadatribuna.com.br/a_edicoes/revista_08_06/fotos/unilabor_pros tata.jp>. Acesso em 03 ago, 2008.

[60] SMITH, C. J.; GALI, H.; SIECKMAN, G. L.; HIGGINBOTHAM, C.; VOLKERT, W. A.; HOFFMAN, T. Radiochemical investigations of ${ }^{99 \mathrm{~m}} \mathrm{Tc}-\mathrm{N}_{3} \mathrm{~S}-$ $\mathrm{X}-\mathrm{BBN}[7-14] \mathrm{NH}_{2}$ : an in vitro/in vivo structure-activity relationship study where $\mathrm{X}=0$-, 3-, 5-, 8-, and 11-carbon tethering moieties. Bioconjugate Chem, v. 14, p. 93-102, 2003. 
[61] STANGELBERGER, A.; SCHALLY, A. V.; VARGA, J. L.; ZARANDI, M.; SZEPESHAZI, K.; ARMATIS, P.; HALMOS, G. Inhibitory effect of antagonists of bombesin and growth hormone-releasing hormone on orthotopic and intraosseous invasiveness of PC-3 human prostate cancer in Nude mice. Clin Cancer Res, v. 11, p. 49-57, 2005.

[62] STANGELBERGER, A.; SCHALlY, A. V.; DJAVAN B. New treatment approaches for prostate cancer based on peptide analogues. Eur Urol, v. 53. p. 890-900, 2008.

[63] THOMAS, R.; CHEN, J.; ROUDIER, M.M.; VESSELLA, R.L.; LANTRY, L.E.; NUNN, A.D. In vitro binding evaluation of ${ }^{177} \mathrm{Lu}$-AMBA, a novel ${ }^{177} \mathrm{Lu}$-labeled GRP-R agonist for systemic radiotherapy in human tissues. Clin Exp Metastasis, DOI 10.1007/s10585-008-9220-0, no prelo.

[64] THRALL, J. H.; ZIESSMAN, H. A. Medicina Nuclear. Rio de Janeiro: Guanabara Koogan, 2003.

[65] TOZER, T. N. Pharmacokinetic aspects of drug administration and metabolism. IN: HANSCH, C.; SAMMES, P. G.; TAYLOR, J. B. Comprehensive medicinal chemistry. Oxford: Pergamon Press, 1990. p. 45-68.

[66] VAN DE WIELE, C.; DUMONT, F.; DIERCKX, R.A.; PEERS, S.H.; THORNBACK, J.R.; SLEGERS, G.; THIERENS, H. Biodistribution and dosimetry of ${ }^{99 \mathrm{~m}} \mathrm{Tc}-\mathrm{RP} 527$, a gastrin-releasing peptide (GRP) agonist for the visualization of GRP receptor-expressing malignancies. J Nucl Med, v. 42, n. 11, p. $1722-1727,2001$

[67] VARVARIGOU, A. D.; BOUZIOTIS, P.; ZIKOS, CH.; SCOPINARO, F.; DE VICENTIS, G. Gastrin-realising peptides (GRP) analogues for cancer imaging. Cancer Biother Radiopharm, v. 19, n. 2, p. 219-229, 2004.

[68] VAUGHAN, D. P. Systems analysis in pharmacokinetics. IN: HANSCH, C; SAMMES, P. G.; TAYLOR, J. B. Comprehensive medicinal chemistry. Oxford: Pergamon Press, 1990. p. 504-546.

[69] DE VISSER, M.; WEERDEN, W. M. van; DE RIDDER, C. M. A.; RENEMAN, S.; MELIS, M.; KRENNING, E. P.; de JONG, M. Androgen-dependent expression of the gastrin-releasing peptide receptor in human prostate tumor xenografts. J Nucl Med, v. 48, n. 1, p. 88-93, 2007.

[70] WASER, B.; ELTSCHINGER, V.; LINDER, K.; NUNN, A.; REUBI, J.C. Selective in vitro targeting of GRP and NMB receptors in human tumours with the new bombesin tracer ${ }^{177}$ Lu-AMBA. Eur J Nucl Med Mol Imaging, v. 34, n. 1, p. 95-100, 2007. 
[71] WEINER, R.E.; THAKUR, M.L. Radiolabeled peptides in diagnosis and therapy. Semin Nucl Med, v. XXXI, n. 4, p. 296-311, 2001.

[72] WILKINSON, G. R. Farmacocinética: dinâmica da absorção, da distribuição e da eliminação dos fármacos. IN: GOODMAN, L. S.; GILMAN, A. As Bases

farmacológicas da terapêutica. Rio de Janeiro: Mc-Graw-Hill Interamericana do Brasil Ltda., 2003, 10 ed., p. 3-24.

[73] ZALUTSKY, M. R. Radionuclide Therapy. In: VÉRTES, A.; NAGY, S.; ZOLTÁN, K. Handbook of Nuclear Chemistry. Netherlands: Kluwer Academic Publishers, 2003. v. 4. p. 315-348.

[74] ZHANG, H.; CHEN, J.; WALDHERR, C.; HINNI, K.; WASER, B.; REUBI, J. C.; MAECKE, H. R. Synthesis and evaluation of bombesin derivatives on the basis of pan-bombesin peptides labeled with indium-111, lutetium-177, and yttrium-90 for targeting bombesin receptor-expressing tumors. Cancer Res, v. 64, p. 6707-6715, 2004.

[75] ZHANG, H.; SCHUHMACHER, J.; WASER, B.; WILD, D.; EISENHUT, M.; REUBI, J. C.; MAECKE, H. R. DOTA-PESIN, a DOTA-conjugated bombesin derivative designed for the imaging and targeted radionuclide treatment of bombesin receptor-positive tumours. Eur J Nucl Med Mol Imaging, v. 34, p. 1198-1208, 2007.

[76] ZHU, J.; GONG, J. Y.; GOODMAN JR; O. B.; CARTEGNI, L.; NANUS, D. M.; SHEN, R. Bombesin attenuates pre-mRNA splicing of glucocorticoid receptor by regulating the expression of serine-arginine protein p30c (SRp30c) in prostate cancer cells. Biochim Biophys Acta, v. 1773, p. 1087-1094, 2007. 